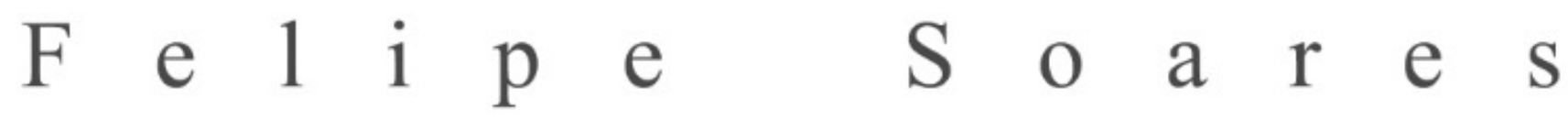
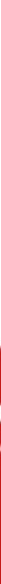


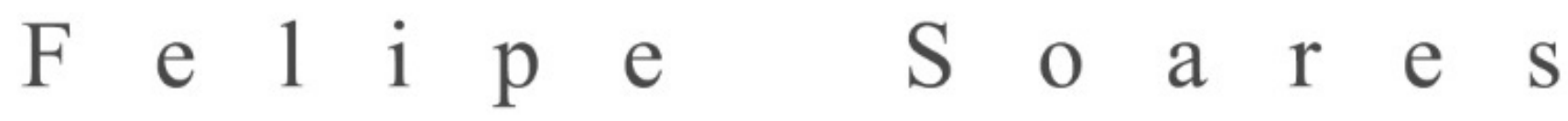
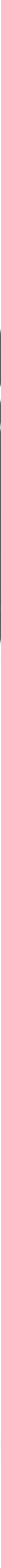

QUE PINTEI MINHA OBLITERAÇÃO, MINHA OBSESSÃO E MINHAS FOBIAS 


\section{CONSELHO EDITORIAL}

Prof. Dr. Adilson Tadeu Basquerot e Silva

UNIDAVI/SC

http://lattes.cnpq.br/8318350738705473

Profa. Msc. Jesica Wendy Beltrán UFCE- Colômbia

http://lattes.cnpq.br/0048679279914457

Profa. Dra Fabiane dos Santos Ramos UFSM- Santa Maria/RS

http://lattes.cnpq.br/0003382878348789

Dr. João Riél Manuel Nunes Vieira de Oliveira Brito

UAL - Lisboa- Portugal.

http://lattes.cnpq.br/1347367542944960

Profa. Dra. Alessandra Regina Müller

Germani

UFFS- Passo Fundo/RS

http://lattes.cnpq.br/7956662371295912

Prof. Dr. Everton Bandeira Martins

UFFS - Chapecó/SC

http://lattes.cnpq.br/9818548065077031

Prof. Dr. Erick Kader Callegaro Corrêa UFN- Santa Maria/RS

http://lattes.cnpq.br/2363988112549627

Prof. Dr. Pedro Henrique Witchs

UFES - Vitória/ES

http://lattes.cnpq.br/3913436849859138

Prof. Dr.Thiago Ribeiro Rafagnin

UFOB

http://lattes.cnpq.br/3377502960363268
Prof. Dr. Mateus Henrique Köhler

UFSM- Santa Maria/RS

http://lattes.cnpq.br/5754140057757003

Profa. Dra. Liziany Müller Medeiros

UFSM- Santa Maria/RS

http://lattes.cnpq.br/1486004582806497

Prof. Dr. Camilo Darsie de Souza

UNISC- Santa Cruz do Sul/RS

http://lattes.cnpq.br/4407126331414

Prof. Dr. Dioni Paulo Pastorio

UFRGS - Porto Alegre/RS

http://lattes.cnpq.br/7823646075456872

Prof. Dr. Leonardo Bigolin Jantsch

UFSM- Palmeira das Missões/RS

http://lattes.cnpq.br/0639803965762459

Prof. Dr. Leandro Antônio dos Santos

UFU- Uberlândia/MG

http://lattes.cnpq.br/4649031713685124

Dr. Rafael Nogueira Furtado

UFJF- Juiz de Fora/MG

http://lattes.cnpq.br/9761786872182217

Profa. Dra. Angelita Zimmermann

UFSM- Santa Maria/RS

http://lattes.cnpq.br/7548796037921237

Profa. Dra. Francielle Benini Agne

Tybusch

UFN - Santa Maria/RS

http://lattes.cnpq.br/4400702817251869

Copyright (c) Arco Editora, alguns direitos reservados.

Copyright do texto (c) 2021 os autores e as autoras.

Copyright da edição ( 2021 Arco Editora. 
Diagramação e Projeto Gráfico : Gabriel E. Machado

Imagem / Capa: Ivan Litenski

Revisão: do autor

Dados Internacionais de Catalogação na Publicação (CIP)

(Câmara Brasileira do Livro, SP, Brasil)

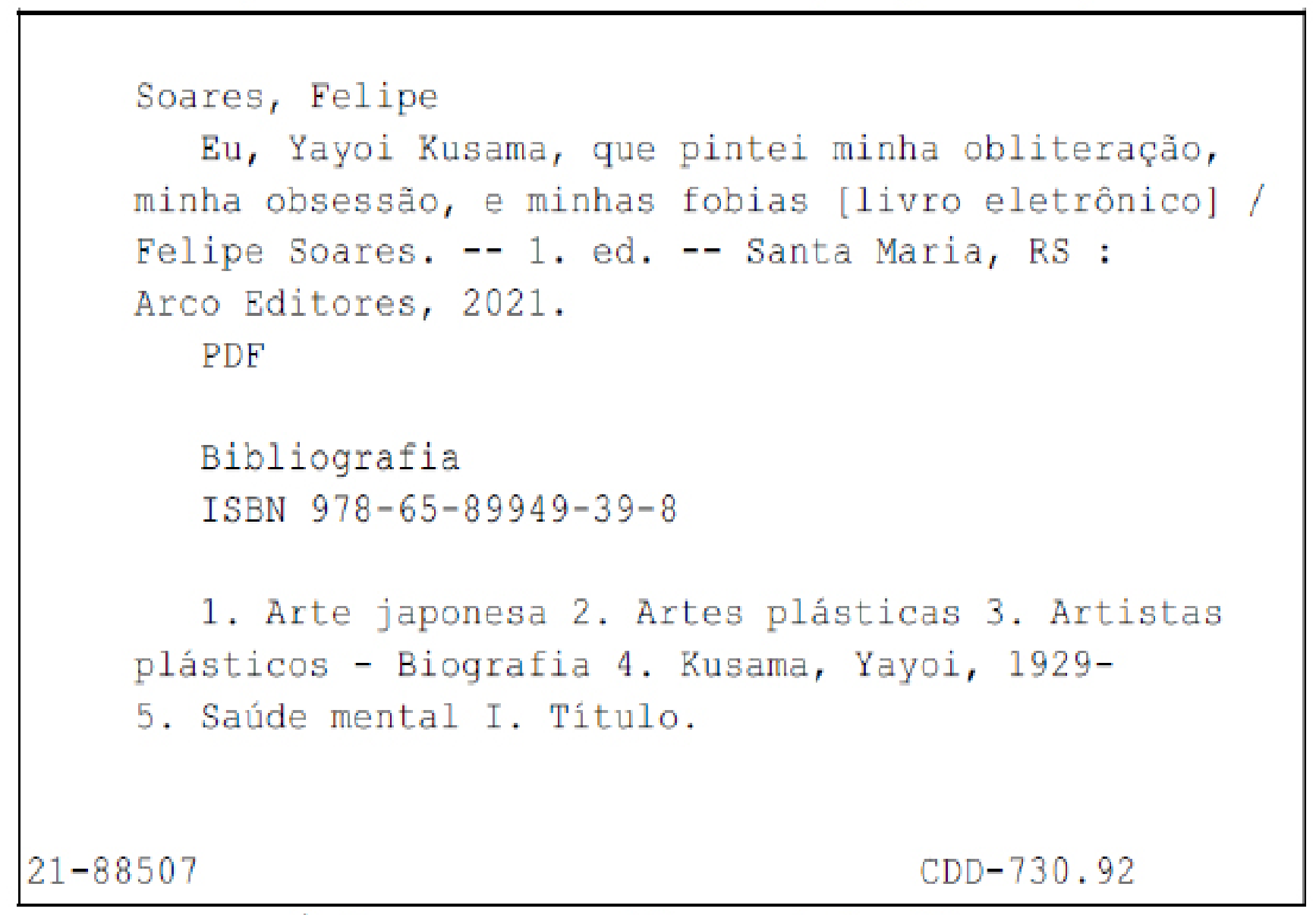

Índices para catálogo sistemático:

1. Artistas plásticos : Vida e obras 730.92

Maria Alice Ferreira - Bibliotecária - CRB-8/7964

doi) $10.48209 / 978-65-89949-39-8$

O padrão linguístico-gramatical, bem como o sistema de citações e referências bibliográficas são prerrogativas de cada autor. Da mesma maneira, o conteúdo e teor de cada capitulo é de inteira e exclusiva responsabilidade de seu respectivo autor. 
À primeira palavra escrita do meu filho, Nicolas, memória - para mim - da combustão de um sorriso inesquecível, -para ele -, da real abertura de um novomundo, eu dedico. 


\section{AGRADECIMENTOS}

Desde o início da minha graduação e mestrado, eu adejava pelos horizontes estéticos da Literatura. No final de 2016, então à deriva, adentrei, em simpatia, na Nau dos Loucos, a convite de minha nova orientadora. Abraçado aos desafios daquela viagem, de um lado, eu forcei minha consciência a rastejar como um mero estilhaço adiante das cinzas da memória, a fiz oscilar por solavancos da história, entrevi a opacidade nos sujeitos. Do outro, porém, pude confirmar que em civilizações sem barcos, os sonhos de fato se esgotam. Todos esses vislumbres deram origem às palavras que dão corpo a este livro, resultado de uma simultaneidade do tempo de estudo e de alegrias que marcaram sua fabricação. Assim, pela competência diante dos saberes ao compartilhar tão inspiradora estética intelectual, à Denise Gabriel Witzel, Regina Baracuhy, Isidora Popovic, Priscila Souza, Suellen Quadros, Vanderléia Josefi, bem como, à Luci Soares, por dedicar-se a me ensinar a desenhar e pintar minhas emoções e ideias (antes de escrevê-las), eu agradeço. 
Those who feel the breath of sadness sit down next to me.

Those who find they're touched by madnes sit down next to me. In love, in fear, in hate, in tears In love,

in fear, in hate, in tears. In love, in fear, in hate, in tears in love, in fear, in ha-a-te! Oh sit down, oh sit down, oh sit down, sit down next to me! Sit down, down, down, down, do-o-own, in sym-pa-thy.

Sit down, banda James

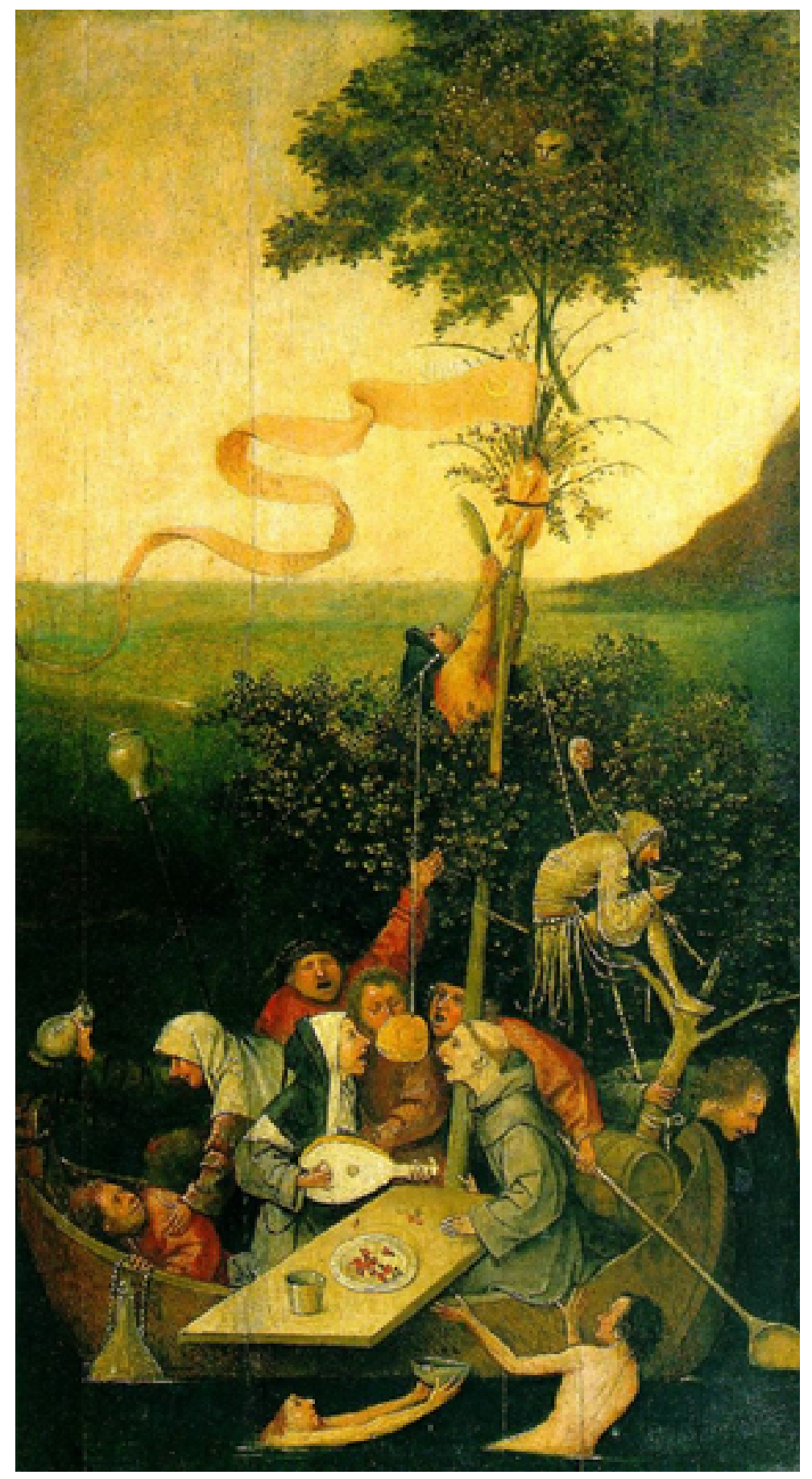

Nau dos loucos, 1490-1500

HiyeronymusBosch $58 \mathrm{~cm} \times 33 \mathrm{~cm}$

Museu do Louvre.

Fonte: BECKETT, 1997, p. 73. 


\section{Prefácio}

\section{Um ponto perdido em meio a milhares de outros pontos}

Figura icônica dos anos hippies, influenciada pelos acontecimentos sociais dessa época, Yayoi Kusama (nascida no Japão, em 1929) começou a ganhar notoriedade ao propor, nos Estados Unidos, uma arte performática explorando o amor livre e a nudez pública com o intuito claro de desestabilizar as tradicionais concepções de sexualidade, identidade e corpo. Nas últimas décadas, ela se tornou uma das mais importantes artistas plásticas do mundo, autoproclamada a "Suprema Sacerdotisa das Bolinhas" em direta referência à marca mais evidente e emblemática de sua obra. Isso porque a repetição e a padronização perfeitamente simétricas de pontos, esferas ou "bolinhas" são recorrentes em toda sua trajetória nas diferentes linguagens e suportes, colorindo espaços, estampas de roupas, telas e corpos. As indefectíveis bolinhas de Kusama nos envolvem em um abstracionismo quase mágico, perturbando nossas noções de espaço e realidade.

Sua fixação por bolinhas teria iniciado na sua infância, em meio a múltiplas formas de alucinações associadas a um transtorno obsessivo compulsivo. Segundo ela conta, se não fosse a arte, "já teria se matado há muito tempo", ou seja, a doença mental e a arte dessa artista se entrelaçam intensamente a partir de desvarios e estratégias de fugas de um iminente suicídio. Ainda nessa direção, vale destacar que quando tinha 44 anos, passou a viver, voluntariamente, em um hospital psiquiátrico em Tóquio. Grande parte de sua obra, muitas delas com valores inestimáveis, foi produzida a partir dessa posição sujeito de artista-louca.

Em que pesem as inúmeras chaves de leitura e de interpretação das narrativas que analisam ora sua arte hipnótica e colorida, ora seus transtornos mentais, há uma singularidade nas regularidades enunciativas, notadamente as que partem da premissa de que sua obra é uma materialização do seu perturbado estado mental. Eis, portanto, a chave que Felipe Soares elegeu para ter acesso ao universo de Kusama e desenvolver sua dissertação de mestrado no Programa de Pós-Graduação em Letras na Unicentro (PPGL), defendida em 2017 e que, agora, está transformada neste belo livro. 
Uma chave, vale dizer, escolhida não de modo aleatório, na medida em que ela é retirada da caixa de ferramentas conceituais proposta pelo filósofo francês Michel Foucault. A partir dessas ferramentas, é possível analisar materialidades discursivas verbais, visuais e verbo-visuais, entendendo o discurso como prática que forma sistematicamente os objetos de que fala e, por suas condições de existência, faz com que certas coisas possam ser ditas/vistas e, muitas vezes, recebidas como verdadeiras em certo momento sócio-histórico. Pautado, portanto, teórica e metodologicamente em reflexões dos Estudos Discursivos Foucaultianos, Felipe atenta fundamentalmente para questões concernentes à linguagem e sua relação inescapável com aspectos sociais, históricos e culturais que produzem o sujeito Kusama subjetivada como uma artista-louca.

O leitor, ao ser instado a ascender à discursividade, ou seja, à não-evidência dos dizeres e das imagens a propósito dessa artista, terá acesso a importantes reflexões arqueogenealógicas que lhe permitirão compreender a produção histórica de um conjunto de práticas discursivas e não discursivas que faz a loucura da persona artística/midiática Yayoi Kusama entrar no jogo do verdadeiro e do falso como modo de resistência, um gesto parresiástico (coragem de dizer a verdade) face aos múltiplos dispositivos de poder que não apenas interditam, calam, agridem o diferente, mas também transformam o infame em celebridade. Assim, as problematizações tão bem articuladas neste livro, formalizadas em uma escrita sedutora e elegante, evidenciam a auto-imagem da artista em meio a seu universo peculiar saturado de bolinhas, disputando significantes (artista, louca, esquizofrênica, genial)

Felipe propõe, em suma, uma maneira singular de compreender como Kusama abraçou sua loucura, produzindo uma obra revolucionária, marcada pelo princípio da acumulação e que, ao desestabilizar as certezas do mundo artístico, mostra, dentre outros aspectos, que um ponto é um caminho para o infinito e que loucura e arte podem se combinar e funcionar como um combustível para o gesto de excelência na criação artística.

Denise Gabriel Witzel 


\section{SUMÁRIO}

INTRODUÇÃO.

.p. 12

I ANÁLISE DO DISCURSO E INTERICONICIDADE p.25

Núpcias acadêmicas: Análise do Discurso e o postulado foucaultiano... p. 26

Desdobramentos da Análise do Discurso: a Intericonicidade p. 33

II IMPASSES DA LOUCURA p.44

Arqueologia p. 45

Premissas genealógicas p.55

Parrhesia: Pierre Rivière, Yayoi Kusam e a coragem da verdade p.61

III UM RETRATO ARQUEGENEALÓGICO p.73

Artistas, monstros, jogos e práticas infames p.75

O Kusama-Word: a loucura em exposição p.84

Perícia artística - a passagem da verdade pelo exame do olhar: p.93

O savoir-faire das verdades "demonstrada/acontecimento" .p.93

O savoir-être do "paradigma indiciário" p.101

IV ARTISTAS LOUCOS: CORPOS EXTRAORDINÁRIOS p.107

Do Surrealismo à Psiquiatria - entre os fantasmas fálicos de Freud e Salvador Dalí. p. 117 
Semiologia Histórica: da repetição estético-patológica de indícios em imagens entre Kusama e Dalí́........................................ p. 127

Intericonicidade: da repetição do discurso da loucura para o sujeito histórico "artista-louco" em imagens entre Kusama e Dalí............. p.141

V EU, YAYOI KUSAMA, QUE PINTEI MINHA OBLITERAÇÃO, MINHA OBSSESSÃO E MINHAS FOBIAS................................................p.151

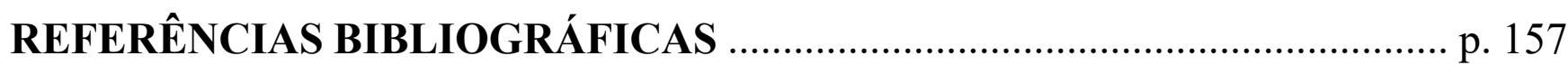

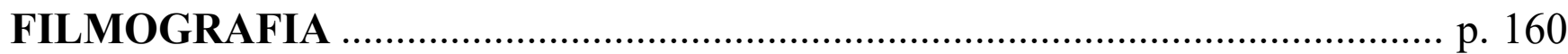

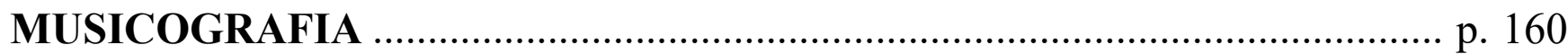

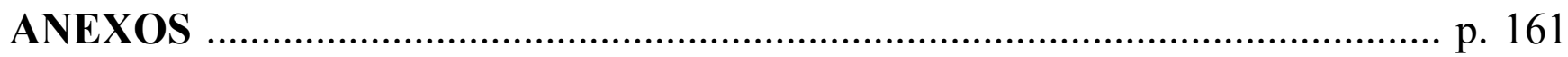




\section{Eu, Yayoi Kusama, que pintei minha obliteração, minha obsessão e minhas fobias}

\section{INTRODUÇÃO}

“Artistas não costumam expressar seus próprios complexos psicológicos diretamente, mas eu adoto meus complexos e medos como temas. Fico aterrorizada só ao pensar que algo longo e feio como um falo me penetre, e é por este motivo que construo tantos falos. Eu construo muitos e muitos deles e então continuo construindo, até que me enterro no processo. A isto dou o nome de "obliteração". ${ }^{1}$

Yayoi Kusama

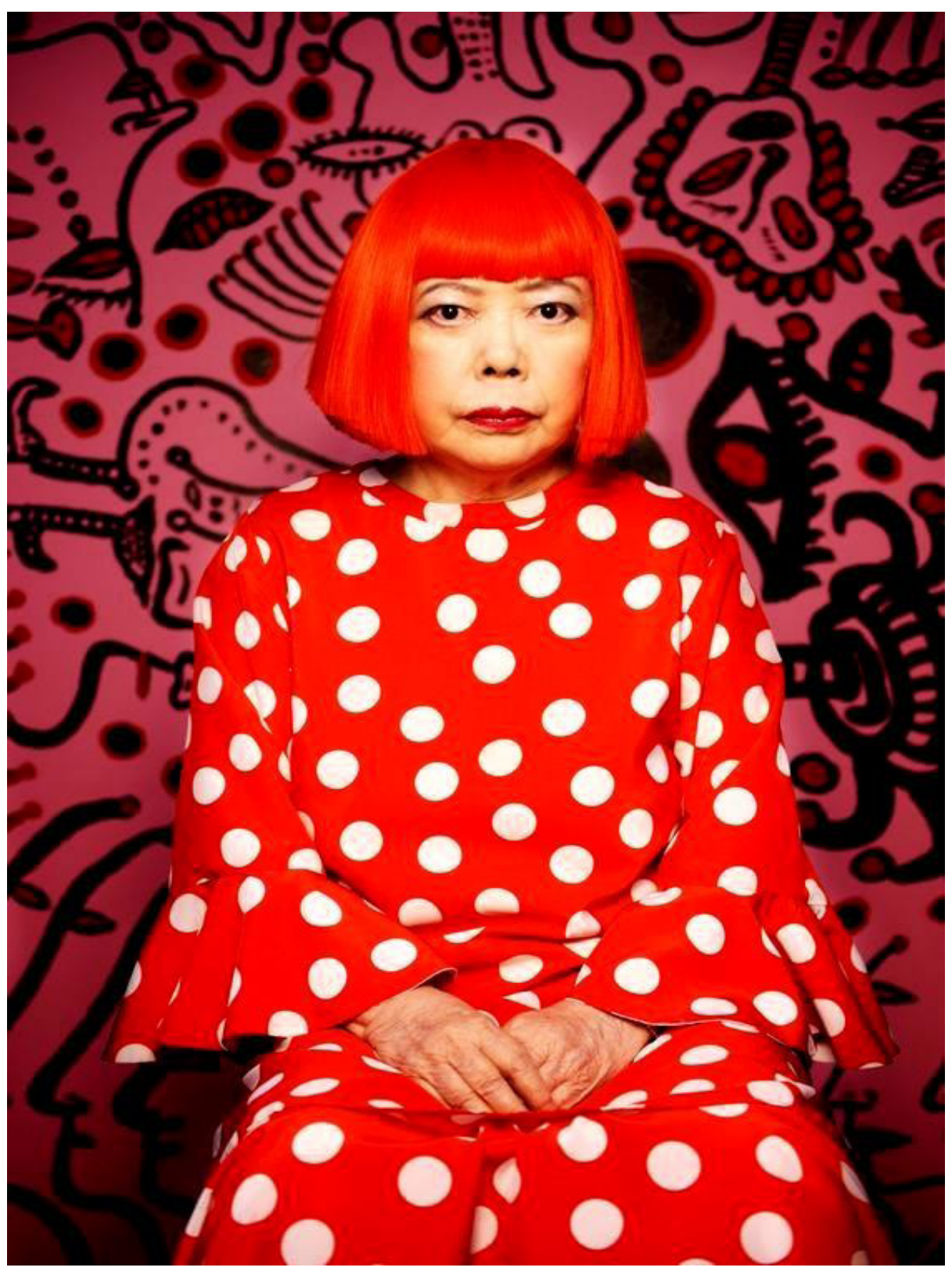

Figura 2 - Yayoi Kusama, 2011.

Fonte: Frances, 2014, p. 191.

1 Declaração de Yayoi Kusama em Yayoi Kusama, Infinity Net: The Autobiography of Yayoi Kusama (2002), trad. Ralph McCarthy. Chicago: The University of Chicago Press, 2011, p. 47. 


\section{Eu, Yayoi Kusama, que pintei minha obliteração, minha obsessão e minhas fobias}

Desde 1977, vive internada - por sua vontade própria - em um hospital psiquiátrico de Tóquio, o Seiwa Hospital for the Mentally, Yayoi Kusama (1929-). Artista plástica japonesa mais conhecida no establishment contemporâneo das artes como a "Suprema Sacerdotisa das Bolinhas"2, ela sai algumas horas, todos os dias, para trabalhar em seu estúdio sempre acompanhada por enfermeiros e de sua equipe particular (empresários, assessores e artesãos).

Renomada artista internacional na atualidade, Yayoi Kusama mantém sua posição nesse establishement de forma inédita (para uma mulher). Enquanto Andy Warhol foi consolidado como "dono" das latas de sopa Campbell, por exemplo, peculiarmente, Yayoi Kusama se proclamou dentro desse restrito hall das artes criandoo seu próprio lugar dentro e fora dele, o Kusama World. Determinada em alicerçar seu espaço nesse meio, em sua juventude escreveu para a revista japonesa Geijutsu Shincho declarando sua intenção de "criar um trabalho inédito, revolucionário, que iria assombrar o mundo artístico internacional" 3 .

Pouco mais tarde, na primeira mostra que a artista organizou na Cooperative Gallery da $10^{\text {th }}$ Street (Brata Gallery), na Nova York dos anos 1959, surgeriam as primeiras manifestações do seu Kusama World. Na ocasião, o gigantesco painel a óleo exposto, o Rede interminável $n^{\circ} 2^{4}$ (1959), executado nas técnicas painterly (gesto rigorosamente repetitivo) e impasto (aplicação sistemática e saliente da tinta sobre atela) propunha aos espectadores composição e tema inusitados. A ordenação pictórica da obra em questão (partículas brancas "esguichadas" sobre um fundo amarelado) sugerindo sêmen/espermatozóides em movimento chamava, notoriamente, a atenção do público e da crítica.

Hoje, o Kusama World é uma rede/plataforma multimidiática espraiada no campo publicitário e bem consolidada no establishment artístico contemporâneo, pela qual a artista enuncia obras de caráter, em geral, psicodélico e repetitivo. De seus elementos temáticos, destacam, continuamente, uma rede de micro e/ou macro pontos esféricos, e outra em que figuram falos de todas as proporções. Sobremaneira, produz-se sobre a linguagem adotada ao longo do trabalho da artista uma reverberação pontilhada e fálica.

2 Título atribuído a Yayoi Kusama pela revista The Village Voice, em 28 de novembro de 1968.

3 Kusama, Yayoi, "Pipuru (People), in Geijtsu Shincho, junho de 1959, p. 31.

4 Tradução livre nossa de Interminable Net No. 2. 


\section{Eu, Yayoi Kusama, que pintei minha obliteração, minha obsessão e minhas fobias}

Pontos e falos, assinatura temática inconfundível de Yayoi Kusama, de tal modo promovem a base de uma linguagem plástica multifacetada. $\mathrm{E}$ - tomando a sinceridade como validade das alegações da artista - nos enunciados ali emaranhados, até então, ter-se-iam designados em sua materialidade significante (traços, pinceladas, instalações, esculturas, fotografias, vídeos, performances, ativismo nudista, roupas e acessórios chez Louis Vuitton) os sintomas de sua doença: alucinações, neurose obsessivo compulsiva, transtorno da despersonalização e depressão.

A despeito de sua enfermidade, quando criança, ainda no Japão, Yayoi Kusama já relatava a aparição de sintomas de uma forte síndrome de despersonalização. O seu diagnóstico "oficial", no entanto, ocorreu só mais tarde. O quadro patológico em questão veio a ser clinicamente atestado em sua vida adulta, concomitante à época de sua exclusão do forte núcleo da arte Pop Underground norte americana pelos poderes/saberes midiático, político, e, sobremodo, artístico. Em 1961, assistida por Yasuhiko Taketomo, psicanalista freudiano japonês instalado em Nova York, Yayoi Kusama foi diagnosticada com "transtorno obsessivo compulsivo" (MORRIS, 2013, p. 46); sua sanidade foi, enfim, confiscada pelo dispositivo médico.

Ainda quanto à sua exclusão do establishment, a interdição mais significativa de Yayoi Kusama aconteceu na Itália, em 1966. Lutando para manter-se no meio, desta veza artista encenava sua obra "ao vivo" instalando o Jardim de Narciso ${ }^{5}$ nos pátios da Bienal de Veneza. Rodeada por 1.500 globos espelhados lançados pelo gramado, ela, vestida num quimono dourado, distribuía cópias de uma declaração atestando o seu talento, escrita pelo crítico britânico Herbert Read. Juntamente à sua performance, propunha a venda dos mesmos globos numa faixa onde se lia "Seu narcisismo à venda". A ação, controversa na época em que muitos comentaristas pontuavam a crescente dominação de artistas comercialmente bem-sucedidos no âmbito da Bienal (tradicionalmente não comercial), ocasionou sua demissão sumária do espaço da exposição, bem como daquele do establishment.

Uma vez segregada dos cenários culturais norte americano e europeu, após o seu retorno à terra natal (1973) em decorrência de um esgotamento físico, Yayoi Kusama foi,

5 Tradução livre nossa de Narcissus Garden. 


\section{Eu, Yayoi Kusama, que pintei minha obliteração, minha obsessão e minhas fobias}

por conseguinte, também renunciada no eixo artístico nipônico. Retomando seu trabalho em Tóquio, ela "percebeu a família, amigos e contatos de negócios ressabiados por sua fama de escandalosa" (MORRIS, 2013, p. 56). Logo, acometida por um período de saúde precária, finalmente, em 1977, fixou residência no hospital psiquiátrico, e durante os anos seguintes a persona pública da artista havia sido apagada do cenário artístico internacional.

Mantendo-se hospitalizada desde então, Yayoi Kusama, de certo modo assujeitada à sua patologia, demonstrou ao mesmo tempo um esforço pessoal prodigioso associado à sua autopromoção artístico-midiática. Em 1982, depois de realizadas cinco exposições individuais em Tóquio, a artista enfim conseguiu o patrocínio da Galeria Fugi Television. Desta vez, seu "novo" trabalho oriundo da intimidade de seu estúdio e do confinamento hospitalar deu "lugar a novos tipos de marca e a sua grife de bolinhas, a espermatozóides contorcidos ou sementes germinantes" (MORRIS, 2013, p. 56) os quais, aos olhos da crítica, ganham a aclamação cada vez mais crescente do público durante a década. O talento da "artista-louca" é amplamente restituído como "arte" pelo establishment contemporâneo.

Reconciliada, portanto, com as searas publicitária e artística, vida e arte da negligenciada/aclamada "artista-louca Yayoi Kusama" imbricam-se numa rede estética de imagens sujeitadoras, "conscientemente" tecida nas tramas do discurso de sua loucura atestada/auto-proclamada. Não obstante, seu estado de obsessão infinita reclama inevitáveis e incontroláveis impulsos suicidas caso seja interrompido o seu irrefreável processo artístico. Logo, nesse establishment, irrompe impulsionada por um discurso clínico uma linguagem estética ímpar: a narrativa episódica dos pontos e falos infinitesimais aplicados em abordagens seriais; eis os enunciados obsessivos emanados do mundo contemplado pela persona Yayoi Kusama.

Delineada, brevemente, a vida de Yayoi Kusama, percebemo-la controlada ora pelo discurso clínico, ora pelo discurso midiático, ora artístico. Ademais, em tais formações discursivas, sua persona (o sujeito) também sugere decorrer atravessada por modos de subjetivação, ou seja, por práticas que possibilitam e asseveram a constituição desse 


\section{Eu, Yayoi Kusama, que pintei minha obliteração, minha obsessão e minhas fobias}

sujeito "artista-louco Yayoi Kusama”. O cenário que se constrói em torno da persona Yayoi Kusama, dessa forma, permite que a pensemos à luz de alguns dos conceitos da Análise do Discurso de linha francesa formulados por Michel Foucault (1926-1984), no que diz respeito, principalmente, ao manejo das "técnicas de si", da "Governamentalidade", da "parrhesia" e do conceito de "verdade", assim associados, consequentemente, às práticas discursivas da psiquiatria, do establishment artístico e da mídia.

Isso posto, ao introduzirmos a persona Yayoi Kusama implicando-a a partir de uma perspectiva de estudo arque-genealógica, de início, destacam-se prontamente de sua longa carreira significativas mudanças de marcha no establishment atreladas à obras/performances psicologicamente carregadas, solitárias e alienantes. Sobremodo, apreendemos de seus extremos, de um lado, um forte tecido conectivo ao longo de sua trajetória: o discurso da loucura. Do outro, um extraordinário comprometimento com a autopromoção, este muito salientado pela mídia.

Neste passo, o exame do nosso olhar decorre de um ponto de vista histórico da regência de poderes e saberes. Logo, pretendemos decifrar os efeitos de evidência da construção de sujeitos discusivisados como "artistas-loucos". Assim, inevitavelmente, aproximamos neste estudo corpos/personas, hoje e outrora, então habitados eatravessados por determinados discursos/dispositivos pelos quais estes viriam (ou não) a assumir seus sentidos, se libertariam (ou não) sua opacidade, e liberariam (ou não) os seus segredos.

Tomando Yayoi Kusama como "artista (sujeito supostamente consciente, tendo em vista o discurso de sua autopromoção midiática) louca (sujeito assim atestado pelos poderes constituídos do discurso psiquiátrico)”, reconhecemos justaposta ao corpo - unidade discursiva - de Yayoi Kusama outra voz que passou da infâmia para a notoriedade, em seu turno, escandida por Michel Foucault. Dessa forma, longe de propormos a descoberta de "verdade(s)" do que se disse/diz acerca da insanidade da referida artista, por meio deste estudo, propomo-nos, antes, evidenciar o embate de poderes/saberes ligados ao eco de vidas regidas, sobretudo no discurso da loucura delineada pelos poderes psiquiátricos e artísticos. Assim, emparelhamos, ao lado da Suprema Sacerdotisa das Bolinhas, o corpo 


\section{Eu, Yayoi Kusama, que pintei minha obliteração, minha obsessão e minhas fobias}

- unidade discursiva - do parricida deCaen, Jean Pierre Rivière, considerado sujeito "monstro" segundo o discurso jurídico e sujeito "louco", segundo o discurso psiquiátrico de/em seu tempo.

Como é sabido, no tocante a Michel Foucault, o filósofo francês foi um pensador de cuja gigantesca obra percebe-se salientada uma militância a favor da vida dos homens infames, bem como das vidas anônimas e paralelas que se manifestavam na medida em que estas colidiam com o poder. Em meio a sua antologia da existência, dentre os memoriais estudados pelo arquegeneologista, ganha visibilidade aquele de Jean Piere Rivière (1814-1840), jovem camponês que, em 1835, degolou a mãe, a irmã e o irmão.

Publicado originalmente $M o$, Pierre Rivière, ayant egorgé ma mère, ma soeuret mon frère (1977) por uma equipe do Collège de France sob a direção de Foucault, a partir do dado dossiê relatado nos Annales d'hygiène publique et de médicine légale de 1836, a partir de seus relatórios médicos, peças judiciárias, o memorial cunhado pelo próprio assassino, em justificativa à publicação da obra, nas palavras de Foucault,

fechado este dossiê, tão duro, tão branco, talvez fosse necessário (gente de discurso que somos, como juízes e os médicos) saber, por nosso lado, deixar a essa vida o lacre que ela própria se deu, e guardar silêncio. Mas, abandonar sem ecoar uma voz que, porque o tempo passou, ressoa em nós hoje e faz nascer palavras - será isso preciso? Não estamos quites com os mortos (FOUCAULT, 2003, p.187).

Em síntese, ao resgatar o memorial de Piere Rivière, Foucault, inquieto com as circunstâncias "locais" do acontecimento referido, as quais permitiram a publicação de uma vasta documentação (para a época) que irrompe e é silenciada tão rápido e totalmente, problematiza "o que havia aí capaz de - após ter chamado tão vivamente a atenção dos médicos - desconcertar o seu saber?" (FOUCAULT, 2003, p. XI), por sua vez, aproximando seu questionamento da seguinte conclusão:

suas ações [as de Pierre Rivière] são discursos, mas o que dizem eles, e por que falam essa língua assustadora do crime? Basta reconhecer a confusão que estas belas monstruosidades, de um horror tão trágico, provocaram no discurso habitualmente tão pleno, tão seguro, dos magistrados e dos médicos para compreender que alguma coisa importante estava acontecendo (FOUCAULT, 2003, p. 194). 


\section{Eu, Yayoi Kusama, que pintei minha obliteração, minha obsessão e minhas fobias}

Desautomatizando os discursos entrecruzados no dossiê Pierre Rivière, e, nesse passo, cerceando a produção de sentidos em ressonância ao acontecimento, que para o filósofo é nesse caso como a "liberdade; ele corta como uma lâmina, agita, frustra ou ataca toda espécie de instituição" (FOUCAULT, 2003, p. 197), assim, Foucault atribui ao camponês de Caen, enfim, a autonomia de um "acontecimento exemplar, [em que] o assassino visa aqui, num mundo estático, ao intemporal da opressão e à ordem do poder.

Como apreendemos, ainda que o acontecimento do jovem parricida francês não tem sido considerado um "grande caso" em sua época, todavia, a abordagem desse dossiê por Foucault e sua equipe promove um profundo estudo das relações que se estabelecem entre a psiquiatria e a justiça penal por mover o acontecimento (o triplo homicídio) em torno do qual "vieram se cruzar discursos de origem, forma, organizaçãoe função diferentes" e pelos quais podemos verificar "uma luta singular, um confronto, uma relação de poder, uma batalha de discursos e através de discursos" (FOUCAULT, 2003, p. XII).

Sobremodo, o embate discursivo em que Foucault abrange a partir das materialidades discursivas escandidas do caso Piere Rivière (Dossiê, Memorial, Pareceres Médico-Legais, Processo etc.), temos um texto "em cuja beleza uns verão prova de razão (daí a razão de condená-lo à morte), outros um sinal de loucura (daí a razão de encerrá-lo por toda a vida)" (FOUCAULT, 2003, p. XII). De tal modo, os protagonistas Yayoi Kusama e Piere Rivière, aparentemente sujeitos em casos distintose não aproximáveis, unem-se no ponto da loucura auto-proclamada (e atestada pelo discurso psiquiátrico) enquanto têm suas subjetividades também reclamadas, um, pelo discurso jurídico, o outro pelo discurso do establishment. Assim, eles se nivelam na perspectiva deste trabalho como pivôs de lutas diversas, no tocante aos confrontos e batalhas (re)encontradas nos jogos desses discursos, atuando nestes como armas e instrumentos das relações de poder e de saber, por perfilarem aí as críticas às ilusões acerca do sujeito.

Na medida proposta, ainda segundo Foucault, quanto à figura do sujeito, é possível compreendê-lo também produzido na sua própria história e pela história que o permeia. Dito de outro modo, a Análise do Discurso de linha francesa foucaultiana nos permite delinear esse sujeito posicionando-o numa possibilidade de produção pessoal histórica, 
intrinsecamente atravessada pela história. Dessa maneira, a AD nos permite abordá-lo a partir de um processo de construção de subjetividades relacionadas às formulações conceituais da crítica às ilusões do sujeito, mais especificadamente, sobre determinados gestos subjetivos/subjetivadores que Foucault chama "técnicas de si", por sua vez, associados à "governamentalidade" e aos "jogos de verdade" (1994), esses também entrecruzados pela noção de "parrhesia" (2002). Sendo assim, a exemplo do gesto analítico outrora empenhado no dossiê Piere Rivière, esta obra visa:

(i) Analisar o embate discursivo cujas produções de sentido (re)produzem uma subjetividade construída em torno do sujeito Kusama; ora artistainfame, ora artista-celebridade, tendo em vista como acontecimento o evento de 1977 (auto internamento num hospital psiquiátrico);

(ii) Examinar enunciados/índices referidos à interpretação da loucura fabricada pelo sujeito Kusama, materializados (ou não) em suas obras, lendo-os, como ensinou Foucault, em sua imersão histórica que pode atestar (ou não) tal loucura, conforme estatuem os poderes/saberes do establishment artístico, em questão, o Surrealismo;

(iii) Escandir os enunciados verbais e não verbais que formam o material de análise deste trabalho, por meio do aporte arqueológico foucaultiano, no que respeita abordar "enunciado" não exclusivamentena ordem linguística, mas sim pela amplitude de sua natureza semiológica, agregando ao processo, para tanto, a metodologia do "paradigma indiciário", de Carlo Ginzburg (2014);

(iv) Desenvolver uma análise das visualidades sob os conceitos de "memória discursiva" e de "intericonicidade" formulados por Jean- Jacques Courtine (2013), conjugando assim vida e obra de Kusama a partir de sua força operadora na memória social, no que respeita o papel da imagem do sujeito histórico "artista-louco" no estabelecimento da memória coletiva, atualmente. 


\section{Eu, Yayoi Kusama, que pintei minha obliteração, minha obsessão e minhas fobias}

No encalço dos objetivos acenados, organizamos esta obra da seguinte maneira: no primeiro capítulo, apresentaremos sumariamente a Análise do Discurso, e, por conseguinte, o conceito de intericonicidade como seu desdobramento nos anos 1970/1980, além de principiarmos os fundamentos da Semiologia Histórica. No segundo capítulo, explanaremos os conceitos arqueológicos e genealógicos foucaultianos, bem como aprofundamos a aproximação do discurso da loucura e do embate entre os poderes-saberes que culminaram/culminam sobre a objetivação/subjetivação de Pierre Rivière e Yayoi Kusama, isso ponderando o conceito de parrhesia em Foucault.

O terceiro capítulo dará visibilidade à relação intrínseca do sujeito Yayoi Kusama aos seguintes conceitos foucaultianos: as "técnicas de si", "governamentalidade", "jogos de verdade" e "verdade-demonstrada"/“verdade- acontecimento". Ainda nesse seguimento da dissertação, também apresentaremos o "método indiciário" de Carlo Ginzburg; saberes da Semiologia Histórica os quais, fazendo convergir história da arte e psicanálise, ressaltam uma força analítica que residena observação do pormenor revelador, mais do que no princípio dedutivo.

Finalmente, no último capítulo, a partir das sistematicidades históricas da língua e das (des)continuidades históricas arroladas à escansão do sujeito Yayoi Kusama, delinearemos a construção do sujeito histórico "artista-louco", ao pensá-lo por meio de uma patologia-estética, detectável por uma arquegenealogia das materialidades imagético-discursivas do que chamaremos "enunciados obras-primas". Para tanto, promoveremos dois gestos analíticos: primeiramente, uma escansão arqueológica dos saberes potológico-estéticos freudianos e surrealistas nas materialidades discursivas verbais e pictóricas arroladas à produção da loucura do sujeito Kusama. Em seguida, a partir das reverberações estético-patológicas encontradas nas margens dos enunciados escandidos, mostraremos uma cronologia visual intericônica, a fim de atualizarmos a posição-sujeito desse "artista-louco" (unidade discursiva) que delinearemos aqui, hoje trajado sob a máscara da "Suprema Sacerdotisa das Bolinhas".

Por sua vez, o material analisado e retomado ao longo dos quatro capítulos é constituído por três materialidades, a saber: 
(i) o livro Yayoi Kusama. Obsessão infinita. Refere-se à obra bilíngue publicada e editada, no Brasil, pelo Instituto Tomie Ohtake, em 2013, composta por, primeiramente, uma cronologia visual das obras de Yayoi Kusama, seguida dos seguintes textos de apresentação sobre vida e obra da artista. O primeiro deles, Yayoi Kusama: "Minha Vida, um ponto”, é escrito por Frances Moris (1958-), a londrina porta-voz de Kusama e curadora chefe de coleção e responsável pelo departamento de arte internacional da Tate Modern. Trata-se do museu britânico de arte moderna, inaugurado em 2009, pertencente ao grupo Tate; conjunto de quatro galerias que compõem o eixo de arte contemporânea britânico(um dos maiores establishments europeus), sendo elas a Tate Britain, a Tate Liverpool, a Tate St. Ives e a Tate Online. O segundo, Canção de uma eterna suicida, é da autoria do canadense Philip Larratt-Smith (1979-). É um curador e escritor independente, que divide seu trabalho entre Nova York e Buenos Aires, autor do projeto Curator ofInternational Projects at Malba - Fundación Costantini in Buenos Aires (2011). Esse texto, por sua vez, é uma tentativa de elucidar a natureza específica da doença de Kusama (as alucinações, a neurose obsessivo compulsiva, o transtorno da despersonalização e a depressão) tendo como base a sinceridade como validade de suas alegações de que adoença seria o manancial de sua arte - ponto fulcral do questionamento por parte da crítica à sua arte. Para tanto, o autor compila as declarações de Kusama emparelhando-as a trechos de estudos científicos de casos clássicos das patologias da loucura (citados a partir de Freud, Jung, Lacan e Moyaert) como pano de fundo para a discussão da especificidade patológica da referida artista.

(ii) Nove imagens da vida e obra de Yayoi Kusama. Seis imagens da vida e obra de Salvador Dalí. Parte da iconografia pesquisada foi extraída do livro acima referido, bem como do web site oficial da artista: Kusama World $^{6}$ e sua web page no Facebook ${ }^{7}$. Os sites apontados interessam a esse estudo na medida em que, ao organizarem uma narrativa a propósito da persona Yayoi Kusama, produzem discursivamente efeitos de sujeito,

6 Disponível em: http://www.yayoi-kusama.jp/e/information/index.html. Acesso em: 12 julho 2017.

7 Disponível em: https://www.facebook.com/Yayoi-Kusama-36938059200/. Acesso em: 12 julho 2017. 
subjetivando-a ora como artista, ora como louca, em uma trajetória que culmina com a posição sujeito de artista-louca (porque se internou no hospital psiquiátrico por vontade própria).

(iii) Pontualmente, os enunciados "Auto-obliteração de Kusama" (1967), filme hipnótico produzido pela artista cujo título se repete continuamente ao longo de sua obra, e "Obsessão por Sexo e Comida" (1966), polêmica foto-arte pertencente a uma das primeiras fases de Yayoi Kusama. Esses dois enunciados compõem, enquanto materialidades discursivas, o corpus sobre o qual voltaremos nosso gesto analítico.

Ao analisarmos discursivamente o referido material, estaremos no encalço das regras que definem o arquivo - explicado mais à frente, considerando, sobremodo, o sistema de enunciabilidade-dizibilidade-visualidade (o que pode ser dito-visto, o domínio da discursividade). Nos itens voltados para construção da constituição do "si", ou seja, a prática do sujeito Yayoi Kusama enquanto artista que promove a si mesma no establishment contemporâneo, optamos por casar, no ferramental analítico, os estudos do campo da Mitologia com os estudos da AD. Isso por considerar que os mitos apresentam uma repetição ritualística na história e também porque identificamos os seus traços na complexa rede do verbal e não-verbal que constrói os sujeitos de hoje.

Assim sendo, os estudos dos mitos assumem importante papel nas áreas que abordam a linguagem, tendo em vista que o mito, anteriormente ao surgimento da capacidade de falar na espécie humana, já pulsava no homem. Sua materialidade, narração e mesmo o seu discurso linear só surgem emparelhados ao nascimento da fala.

Tratando-se, portanto, de um texto base, o mito nos ajuda na compreensão dos ideários mais essenciais que inquietam o homem desde os primórdios.

Uma vez olhando para o mito, podemos (re)interpretar o presente. Se o mito do "artista-louco" se apresenta também nos discursos que atravessam o sujeito histórico Yayoi Kusama, isso poderia nos demonstrar que a artista alimenta um fenômeno cultural e social. Tendo, então, seu lugar inserido na sociedade que a gerou, desse modo, 


\section{Eu, Yayoi Kusama, que pintei minha obliteração, minha obsessão e minhas fobias}

escolhemos abordar sua persona, nesta pesquisa, em razão do grande potencial que sua vida e obra representam, no sentido de disseminar estudos futuros sobre os fenômenos iconográficos das sociedades globalizadas atuais, bem como contribuir com os estudos sobre os processos de novas construções/subjetivações dos sujeitos.

Ora, de relevante importância é, diante do exemplo dessa corajosa produção pessoal-histórica, perguntarmo-nos: quem somos nós hoje? Ao sabermos que somos impregnados por vestígios históricos que atribuem sentidos à nossa constituição como sujeitos, conforme ensinou Foucault, olhando para a memória dos sujeitos loucos e artistas e a especificidade das condições que permitiram a produção do sujeito persona Yayoi Kusama - artista-louca, podemos, em sua busca por nossa identidade, fazer um diagnóstico do sujeito artista/louco na atualidade.

Desse modo, é permitido, seguramente, dar visibilidade ao deslocamento dos sujeitos e dos dispositivos que, subjetivando-nos, colocam em funcionamento as classificações e reforçam a sanidade/loucura dos sujeitos e dos espaços que ocupam. O cenário espacial-cronológico que apresentaremos nesta pesquisa é aquele do establishment, cujo poder/ saber é gerenciado, de um lado, por seus curadores sujeitos estatuários, autoridades de uma "verdade" (demonstrada? estratégica? a verdade da parrhesia?), ou seja o valor que aí se agrega às "obras-primas". Do outro, nesse establishment, percebemos a figura/gênio dos artistas que aí surgem continuamente ligados à persona do louco.

Diante disso, perguntamo-nos, assim: como Kusama assume hoje a função do "artista-louco" para o establishment, posição outrora reservada aos loucos que aí fizeram (ou não) de sua loucura obras-primas? Com isso, seria possível, em termos de enunciado (FOUCAULT, 2010) interpretarmos na materialidade significante estética de uma obra-prima gestos, índices estéticos da loucura? Finalmente, aproximando para a Análise do Discurso o fenômeno da interconicidade (COURTINE, 2013), sob qual máscara (FOUCAULT, 2007) a atualidade do sujeito "artista-louco" ainda manteria seu rastro histórico e como este se admite/constrói (ou não) aos olhos da crítica e da mídia? 
De resto, o interesse pelo assunto abordado nesta dissertação surge em prol da continuidade dos questionamentos e inquietações acerca dos processos de significação que definem as relações que se estabelecem entre os seres humanos - consigo próprios e uns com os outros. Nesse sentindo, atentamo-nos também para a posição da artista contemporânea, mulher, no atual establishment, lugar raramente ocupado tal como na escala monumental de Yayoi Kusama. Partindo, então, do sujeito "artista-louco", o percurso analítico desta dissertação focaliza a constituição desse si que jaz atravessada por poderes-saberes e cuja estética-patológica, essa decifrada também a partir de manobras histórico-linguísticas, parece-nos uma tarefa urgente e interminável. 


\section{Núpcias acadêmicas: Análise do Discurso e o postulado foucaultiano}

Nenhuma memória pode ser um frasco sem exterior,

Michel Pêcheux

França, maio de 1968. O espírito crítico ofuscava a cidade luz das universidades às ruas num período marcado sob o impacto das relações entre política, a vida acadêmica parisiense e a sua classe de trabalhadores. Sobremodo aí pulsava a emergência de novas formas de comunicação e de pensamento. Em meio à política do governo do regime gaulista (instalado em 1958), de um lado ebulia a revolta estudantil reclamando pela manutenção do establishment acadêmico; um sistema educacional e universitário, engessado havia décadas, jaz em crise. Do outro, espontaneamente, eclodiam revoltas associadas ao desemprego dos trabalhadores das linhas de montagem em frente à "crise profunda no processo de produção de tipo fordista" (THIOLLENT, 1998, p. 65) que se alastrava no país já desde os anos de 1960 .

Sobre os acontecimentos de 1968, convém ainda ressaltar que eles eram atravessados pela interferência de inúmeros outros eventos históricos. Dentre eles, destacam-se "o movimento de oposição à guerra da Argélia e de apoio à [sua] descolonização no início da década" (THIOLLENT, 1998, p. 65) na própria França, como também

a oposição à guerra americana no Vietnã [que] mobilizava a juventude tanto nos EUA quanto na Europa. Além disso, a revolta negro-americana, a luta armada na América Latina e na África, a Revolução Cultural na China (1966-1969) [que também] contribuíam para o clima de revolucionarização da juventude e do mundo universitário. [Logo,] a revolta estudantil espalhou-se na França com esse pano de fundo complexo e internacional, que dava exemplos heróicos de possíveis mudanças radicais (THIOLLENT, 1998, p. 65).

No conturbado cenário que se construía, considerando ainda os movimentos feministas, em linhas gerais, entre os principais temas de contestação universitária, uma questão ganhava destaque: qual era o papel do intelectual em meio a tanto? Em outras palavras, vinha à tona a recusa do caráter classista da universidade, uma vez propostas a 


\section{Eu, Yayoi Kusama, que pintei minha obliteração, minha obsessão e minhas fobias}

denúncia da falsa neutralidade e da falsa objetividade do saber; a denúncia da parcelização e tecnocratização do saber; a contestação doscursos ex cathedra; a denúncia dos professores conservadores ligadosà política do governo; o questionamento do lugar que, na divisão capitalista do trabalho, os diplomados irão ocupar; [e] a denúncia da escassez de possibilidade de empregos qualificados (problemas dos “débouchés”) (THIOLLENT, 1998, p. 70).

Como se apreende, os anos de 1960 foram enredados por vários eventos históricos, assim como também foram perfilados no auge do Estruturalismo, conforme preconiza Michel Thiollent (1998). Movimento intelectual de origem interdisciplinar, advindo da filosofia, das ciências sociais e da psicanálise, o estruturalismo almejava atingir um maior grau de cientificidade por meio da educação, e, se possível, fazê-lo também a partir da “formalização das estruturas invariantes que estão por trás dos discursos ou das atividades humanas" (THIOLLENT, 1998, p. 87). Dessa maneira, o estruturalismo tinha suas raízes emaranhadas tanto na Linguística - ciência na qual vigoravam a análise estrutural e semiótica como na Antropologia sob a influência do filósofo belga Claude Lévi-Strauss (1908-), além da perspectiva estruturalizada da Psicanálise de Jacques Lancan (1901-1981), bem como do Marxismo, esse último enquanto objeto da releitura estruturalizante de Louis Althusser (1918-1990).

De tal modo, a conjuntura da prática estruturalista se posicionava contra o Existencialismo, explicitamente definido como Humanismo, de Jean-Paul Charles Aumard Sartre (1905-1980), que desde o início dos anos de 1950 dominava o palco da filosofia francesa. Em seu turno, Sartre, que desenvolveu posições com base na fenomenologia, no existencialismo e na leitura de Martin Heidegger (1889-1976) e Karl Marx (1818-1883) era criticado como "humanista e pensador do sujeito ou da subjetividade" (THIOLLENT, 1998, p.88). Já os estruturalistas, por sua vez, trabalhavam a partir de fontes filosóficas diversas, tendo destas em comum a "crítica ao "homem" enquanto categoria filosófica e ao humanismo em geral" (THIOLLENT,1998, p.88).

De igual forma, a essa momentânea esteira histórica arrolada ao Estruturalismo também se constitui um novo campo de saber oriundo desse deslocamento do pensamento intelectual francês em militância nos anos de 1960. Trata-se da Análise do Discurso francesa cujo criador é Michel Pêcheux (1938-1983). 


\section{Eu, Yayoi Kusama, que pintei minha obliteração, minha obsessão e minhas fobias}

A Análise do Discurso, estabelecida na França nos anos de 1960, ao mesmo tempo se apóia e nega o Estruturalismo até então fortemente presente nas práticas políticas e científicas da época. Seus fundamentos teóricos e metodológicos se constituem a partir de três regiões do conhecimento científico, a saber: o Materialismo Histórico, a Linguística e a Teoria do Discurso, essa última como teoria de determinação histórica dos processos semânticos (PÊCHEUX; FUCHS, 1975). Assim, sendo todos esses campos de conhecimento atravessados e articulados por meio de uma teoria da subjetividade de natureza psicanalítica, com isso, pode-se dizer que o nascimento da Análise do Discurso foi marcado pelo trinômio Saussure-Marx-Freud. Propicia-se, desse modo, uma articulação entre três domínios disciplinares derivados desses autores: a Linguística, o Marxismo e a Psicanálise.

Dessa maneira, conforme assevera Orlandi (2000), podemos afirmar que a Análise do Discurso situa-se: (i) na Linguística, dada a problematização do corte saussureano. Nesse sentido, a AD compreende que a língua, conforme ensinou Saussure, tem sua ordem própria, mas ela só é parcialmente autônoma. Diferentemente em relação à Linguística, porém, a AD reintroduz a noção de sujeito e de situação na análise da linguagem; (ii) no Materialismo Histórico, a considerar a releitura da obra de Marx feita por Althusser. Com base na teoria da interpelação do sujeito, pela qual só existe ideologia pelo sujeito e para os sujeitos, é que Pêcheux trouxe para a AD a noção de assujeitamento. Logo, segundo Pêcheux, não há discurso sem sujeito e não há sujeito sem ideologia, pois, o indivíduo é interpelado em sujeito pela ideologia e assim a língua ganha sentido; (iii) na Psicanálise, com base na releitura lacaniana de Freud. É nesse campo que emerge a idéia do sujeito na sua relação com o simbólico, nesse caso, pensando o inconsciente como estruturado por uma linguagem.

Dessa maneira, tal "tríplice aliança estruturalista" promoveu a desestabilização de conceitos tendo por objetivo as ressignificações, os deslocamentos e apagamentosdas categorias, tais quais: a unidade, a totalidade, a verdade e a racionalidade. Nesse sentido, a prática da Análise do Discurso visa viabilizar instrumentos a fim da descrição e análise de uma 'nova língua', uma 'nova história' e, por conseguinte, um 'novo sujeito'.

Acerca da constituição das três fases da $\mathrm{AD}$, em seu princípio, conforme estatui o filósofo marxista, a análise automática do discurso, a AD-1 (1975), se ampara na 


\section{Eu, Yayoi Kusama, que pintei minha obliteração, minha obsessão e minhas fobias}

metáfora da maquinaria discursivo-estrutural, na qual o processo de produção dos discursos ocorre de forma autodeterminada e isolada. Esta pretende interpretar - no processo da análise linguística - determinadas variações dadas entre os traços empíricos discursivos então observáveis no corpus das sequências discursivas. Isso, sempre apartir da análise das sequências discursivas individuais para considerar o corpus na íntegra, por fim. O que se pressupõe, nesse processo, é a possibilidade de o corpus ser um conjunto de enunciados constitutivos de um mesmo discurso, ou seja, de uma mesma máquina discursiva. Dado tal processo de interpretação sobre as estruturas das máquinas discursivas - como um mito ou uma ideologia, por exemplo - elas se justapõem; isto é, um discurso pode ser identificado pela sua diferença em relação a outro.

Avançando na formação da Análise do Discurso, em seu segundo momento, a AD-2 (1975-1979), a referida justaposição dos processos discursivos é questionada e começam a surgir, nesse ritmo as formações discursivas (termo emprestado de A Arqueologia do Saber (1969), já subentendido por interdiscursividade, além de observado o entrelaçamento desigual dos processos discursivos. Entrelaçam-se nessa concepção, consequentemente, inúmeras e distintas relações de força que mobilizam a estrutura dos processos discursivos. No sentido que se estabelece, uma formação discursiva (FD), subentendida por interdiscursividade, ou seja, sendo sempre "invadida"(FOUCAULT, 2010) por outras formações discursivas, "faz explodir" a noção da maquinaria discursiva, esta outrora fechada sobre si.

Logo, é em seu terceiro momento, a AD-3 (1980-1983), que se reconhece o princípio da maquinaria discursiva doravante abolido pelo princípio da heterogeneidade (constitutiva e mostrada) ${ }^{8}$, isto é, heterogeneidade constitutiva do discurso e heterogeneidade

$8 \quad$ Conceito de Jacqueline Authier-Revuz (1982) que incorpora o princípio do dialogismo de Bakthin desenvolvendo as investigações sobre os efeitos de polifonia os quais, segundo a autora, manifestam-se sob duas formas de heterogeneidade: a constitutiva e a mostrada. Ao abordar que o sujeito pode ser clivado entre o consciente e o inconsciente, considera-o, portanto, não como uma entidade homogênea, mas sim como o resultado de uma estrutura complexa. Tal cisão não significa uma dualidade em que bastaria somar as duas partes para se ter a totalidade do sujeito. Isto é, o sujeito assim entendido não controla o seu dizer o tempo todo, uma vez que ele não é só consciente e muitas vezes quem fala é o inconsciente que rompe as cadeias da censura, deslizando, por exemplo, em sentidos indesejados/incontrolados. Amparada à teoria freudiana, considera também que o sujeito é descentrado, pois ele perde a sua centralidade, não sendo mais o senhor de sua morada.Valendo-se dessa teoria, Authier-Revuz sustenta a tese de que a homogeneidade do discurso é uma ilusão, tendo em vista que o sujeito acredita estar produzindo algo que ele pode controlar, sentindo-se o centro do discurso, responsável pelo sentido de seus dizeres, mas ao ser atravessado pelo inconsciente e por outros discursos, instala-se, desse modo, a "ilusão do eu". 


\section{Eu, Yayoi Kusama, que pintei minha obliteração, minha obsessão e minhas fobias}

mostrada no discurso que

representam duas ordens de realidades diferentes: a dos processos reais de constituição de um discurso e a dos processos não menos reais, de representação, num discurso, de sua constituição. Não se trata de assimilar um ao outro, nem de imaginar um relacionamento simples, de imagem, de tradução, nem de projeção de um no outro; essa relação de correspondência direta é interditada tanto porque ela faria supor uma transparência do dizer em suas condições reais de existência quanto pela irredutibilidade manifesta das duas heterogeneidades (AUTHIER-REVUZ, 1990, p. 32).

Nesse momento de 'abertura' da máquina discursiva, admite-se então como o objeto da análise as relações entre diferentes discursos, e não mais apenas o discurso isolado em si. Isto é, admite-se o discurso do outro no 'próprio' discurso. Assim, a abordagem da noção de sujeito, para a Análise do Discurso pêcheutiana, passa a compreender língua como um efeito da história e, consequentemente, o sujeito como efeito do discurso ${ }^{9}$. Logo, esse sujeito que é efeito produzido pela máquina discursiva com a qual se identifica, por ela é assujeitado. Isso, pois, dessa perspectiva o sujeito não produz intencionalmente seus discursos e tem a ilusão de ser a fonte de seus dizeres.

Uma vez alterados o princípio da maquinaria discursiva pelo princípio da heterogeneidade na $\mathrm{AD}-3$, quanto ao processo da análise de ordenação determinada e fixa, de início linguística (as sequências individuais) e, posteriormente, discursiva (o corpus como todo), torna-se assim uma análise linguístico-discursiva. Isso quer dizer então que, uma vez combinados alternativamente os dois tipos de análise, promove-se a produção de sucessivas interpretações do corpus analisado. Assim, as interpretações do corpus antes exploradas em sua justaposição, agora decorrem por uma perspectiva 'em espiral'.

Como resultado, surge a Análise do Discurso que aborda o texto como materialidade do discurso, texto esse cuja produção de sentidos se dá apenas quando se reconhece sua relação intrínseca à(s) condição(ões) sócio-histórica(s) na qual ele vem a ser produzido. Verifica-se, sobremaneira, que essa Análise do Discurso parte do texto, para, em seguida, relacioná-lo com o acontecimento correspondente, e, uma vez emaranhados texto e discurso, essa análise apresenta, portanto, uma resposta histórica e social.

9 Já língua e sujeito, na Análise do Discurso foucaultiana, são assim compreendidos: língua como função de regras, e o sujeito não é admitido como produto de um discurso, mas sim uma posição que vem a ser ocupada por determinados indivíduos. Logo, o sujeito ou aquilo que ele diz não é formado tão pouco é determinado pelo discurso. 


\section{Eu, Yayoi Kusama, que pintei minha obliteração, minha obsessão e minhas fobias}

Constitui-se assim, ao ponderarmos os contextos sócio-históricos decorrentes dos anos de 1960 no que diz respeito à "crítica coletiva do conhecimento "inadequado", aquele que só é capaz de justificar o statu quo" (THIOLLENT, 1998, p. 93) nessa França que pulsava pela emergência de novas formas de comunicação e de pensamento a importância de Michel Pêcheux e, consequentemente, da Análise do Discurso. Não obstante, concomitante ao peso intelectual e esteira sócio-histórica acenados, também se destacam, respectivamente como brasas em meio ao movimento jaz inflamado, As Palavras e as Coisas (1966) e a Arqueologia do Saber (1969), do filósofo francês Michel Foucault (1926-1984). Trata-se de obras polêmicas cuja crítica as convergiam para um tipo de análise e pensamentos considerados estruturalistas.

Em 1980, em meio a esse território em que a Análise do Discurso (doravante AD) se revolvia e construía suas posições, pontuam-se duas importantes ações que direcionaram os canteiros de pesquisa em Análise do Discurso. São elas: o Colloque Materialités Discursives, na Université Paris $X$, e a defesa da tese de Jean-Jacques Courtine, Análise do Discurso Político: o discurso comunista endereçado aos cristãos -trabalho cujos entrecruzamentos teóricos refletidos diante das inquietações e combustão de idéias provocadas na época trazem o postulado de Michel Foucault para dentro do terreno da Análise do Discurso.

Nesse momento, chamamos atenção para a proposta de análise dos processos históricos de subjetivação do ser humano via discursos ensinada por Michel Foucault, a qual, por subsidiar um incontável número de pesquisas torna possível hoje falarmos tanto de uma $\mathrm{AD}$ pêcheutiana como de uma $\mathrm{AD}$ foucaultiana - a qual, antes de tudo, registramos nossa filiação teórica na presente dissertação ${ }^{10}$. A saber, no Brasil, o campo de estudos denominado Análise do Discurso, que remonta o final dos anos de 1980, é constituído por uma multiplicidade de abordagens, métodos e objetos de análise. ${ }^{11}$

10 Portanto, o uso da sintagma 'Análise do Discurso' e do seu acrônimo, AD, fazem referência, neste trabalho, à perspectiva ensinada por Michel Foucault.

11 Tal variedade deriva da própria complexidade da concepção de discurso, uma vez que, envolvendo a linguagem, "os sujeitos e as determinações sociais e históricas, necessitam da articulação de vizinhanças teóricas e possibilita enfoques a partir de ângulos diversificados” (GREGOLIN, M. R. Discurso, semiologia e história. In: Análise do Discurso e semiologia: enfrentando discursividades contemporâneas. São Carlos: Claraluz, 2011, p. 83). A respeito de seus canteiros de pesquisa foucaultianano país, destaca-se, atualmente, o Grupo de Estudos de Análise do Discurso (GEADA), sediado na FCL- UNESP-Ar, Araraquara, SP, no âmbito de programa de pós-graduação em Linguística e Língua Portuguesa, sob a coordenação da prof. ${ }^{a}$ Dr. ${ }^{a}$ Maria do Rosario F. V. Gregolin. De sua produção, no que diz respeito à articulação da $\mathrm{AD}$ com teorias semiológicas, seu trabalho com materialidades imagéticas/midiáticas remonta desde os anos de 2000. 


\title{
Eu, Yayoi Kusama, que pintei minha obliteração, minha obsessão e minhas fobias
}

Prosseguimos acerca da obra de Michel Foucault e sua contribuição para a AD. Como se sabe, o conceito de sujeito atravessa a obra foucaultiana, ao passo que se estabelece a seguinte questão - fulcral ao que se refere ao pensamento de Foucault: Quem somos nós hoje? Corroborando a questão, destacamos de seu texto Sujeito e Poder (1995) a inquietação motora de seu trabalho. Em suas próprias palavras:

\begin{abstract}
eu gostaria de dizer, antes de mais nada, qual foi o objetivo do meu trabalho nos últimos vinte anos. Não foi analisar o fenômeno do podernem elaborar os fundamentos de tal análise. Meu objetivo, ao contrário, foi criar uma história dos diferentes modos pelos quais, em nossa cultura, os seres humanos tomaram-se sujeitos. Meu trabalho lidou com três modos de objetivação que transformam os seres humanos em sujeitos (FOUCAULT, 1995, p.1).
\end{abstract}

Diante do exposto, entendemos como condição imprescindível apreendermos a produção intelectual foucaultiana, no que se refere ao trato dos modos de subjetivação, conhecida como as 'três épocas' (1960-1984), a saber, a arqueologia do saber, a genealogia do poder e a genealogia da ética. Assim, diante do corpus explorado nesse trabalho, procuramos estabelecer uma análise que, segundo estatui M. R. Gregolin(2007, p. 10), pressupõe uma arque-genealogia cuja base teórico-metodológica nosorienta na análise dos três modos de objetivação, os quais, nesse medida, transformariam o ser humano num sujeito “objetivável por ciências, normatizável por disciplinas e dotado de uma subjetividade pela invenção de uma ciência sobre o sexo" concomitantemente.

Explanada a base teórica que fundamentará parte dos gestos analíticos desta pesquisa, perpassemos, resumidamente, a obra de Foucault. Em seu momento arqueológico (História da loucura, 1961; O nascimento da clínica, 1962; As palavras e as coisas, 1966; A arqueologia do saber, 1969; A ordem do discurso, 1970), Foucault abraça os saberes como temática central, em especial os saberes médico e psiquiátrico. Para o pensador, os saberes - construções históricas - produzem os sujeitos bem como os objetiva. Nos estudos dessa época, Foucault se volta simultaneamente à compreensão sobre a emergência das instituições que se amparam nesses saberes para classificar os sujeitos. É o caso, por exemplo, dos asilos, clínicas e manicômios que, munidos de suas especificidades, separavam os doentes dos saudáveis, os loucos dos sãos.

Já na genealogia do poder (A vontade e as formas jurídicas, 1973; O poder psiquiátrico, 1973-1974; Vigiar e Punir, 1954; Os anormais, 1975-1976; Em defesa da so- 


\section{Eu, Yayoi Kusama, que pintei minha obliteração, minha obsessão e minhas fobias}

ciedade, 1975-1976; Microfisica do poder, 1979; Eu, Pierre Rivière..., 1979) Foucault não abandona os saberes, porém, focaliza sua atenção sobre o poder e para a noção do dispositivo: as estratégias de controle desse(s) poder(es). Dos dispositivos, salientam-se, notavelmente, o dispositivo da prisão (de natureza disciplinar, a fim de produzir corpos dóceis, regrados e úteis) e o dispositivo jurídico (aquele que estatui o status de verdadeiro, classificando um indivíduo como criminoso ou não).

Por fim, na genealogia da ética (A hermenêutica do sujeito, 1981-1982; História da sexualidade I, 1982; História da sexualidade II, 1984; História da sexualidade III, 1984) Foucault prossegue com a temática dos dispositivos, pontualmente, o da sexualidade. Em seu último período, o arquegenealogista promove uma reflexão acerca dos processos de subjetivações via moralidade e sexualidade, tomando-as, intrinsecamente ligadas uma a outra, como produtos de construções sócio-históricas. Colocadas as premissas que envolvem o nascimento da Análise do Discurso e suas núpcias com o postulado foucaultiano, antes de nos atermos especificamente aos pressupostos arqueológicos e genealógicos de Michel Foucault, passemos ao nascimento de outra frente epistemológica aqui necessária.

\section{Desdobramentos da Análise do Discurso: a Intericonicidade}

Neste momento, trazemos à baila a gênese cujos pressupostos estão para uma arqueologia das imagens; mais próximo de uma genealogia das imagens de nossacultura, mediante o conceito de "intericonicidade" (2013), formulado por Jean-Jacques Courtine (1945-). Trata-se de um conceito tanto filiado no seio da Semiologia, da Antropologia, como na Análise do Discurso cujo surgimento vem para romper com os limites epistemológicos ${ }^{12}$ referidos aos processos de análise nos domínios do campo do discurso.

O confronto dos limites epistemológicos em torno do pensamento ocidental sobre o poder e o valor das palavras acerca das representações gráficas e de objetos no que consiste em estabelecer um sentido para as coisas e os seres é, em seu turno, um debate deveras antigo. No que diz respeito a examinar o caráter da Semiologia Histórica, conceito

12 Referimos-nos ao significado de episteme em consonância ao pensamento de Foucault: um paradigma geral segundo o qual se estruturam, em uma determinada época, os múltiplos saberes científicos, que por esta razão compartilham, a despeito de suas especificidades e diferentes objetos, determinadas formas ou características gerais. Logo, o surgimento de uma nova episteme estabelece uma drástica ruptura epistemológica por abolir a totalidade dos métodos e pressupostos cognitivos anteriores, implicando, portanto, uma concepção fragmentária e não evolucionista da história da ciência. 


\section{Eu, Yayoi Kusama, que pintei minha obliteração, minha obsessão e minhas fobias}

de interesse a Michel Foucault para a análise das visualidades, e, evidentemente, um aspecto crucial em nossa pesquisa, reservamos a análise desta ao capítulo seguinte.

Grosso modo, neste momento, apenas introduzindo o tema, sabe-se que são oriundos desde a Antiguidade grega os estudos chamados de semióticos - de Semeîon, Semeiotik, Semiologia, Semiótica - (e posteriormente também linguísticos). Esses avançaram para a Idade Média, passaram pelos pensadores do Iluminismo e chegaram ao início do século XX quando se experimentava uma ambiciosa tentativa de sistematização que “acabaria por se dividir em duas correntes básicas: a estruturalista, mais associada à estrutura verbal da linguagem humana, e a interpretativa, mais ligada aum campo simbólico e filosófico" (CASTRO, 2011, p. VII). Atenhamo-nos a essa passagem da Semiologia até sua imersão no campo da $\mathrm{AD}$, por hora.

É no século XX, como visto, que a Semiologia - ciência que se ocupa então do estudo do signo (a menor partícula comunicacional dotada de sentido) - se estabelece por meio de dois principais nomes nessa linha de estudos. O primeiro é o do genebrino Ferdinand de Saussure (1857-1913) cuja base analítica que associa o signo com a Linguística (ciência do estudo da estrutura da língua, suas manifestações verbais e escritas) e suas relações com o tecido social, nasce em 1906 em seu Cours de Sanscrit e segue se desenvolvendo nos cursos ministrados seguintes até 1912 na Université de Genéve. Por sua vez, a transcrição das doutrinas linguísticas de Saussure, a partir dos manuscritos extraídos de suas aulas, é publicado primeiro e postumamente em 1916 no célebre Cours de Linguistique Générale por seus alunos Charles Bally e Albert Sechehaye com a colaboração de Albert Riedlinger.

Já o segundo é do norte-americano Charles Sanders Peirce (1839-1914). Trata-se do fundador do Pragmatismo e também da Semiótica no que diz respeito à análise das implicações não verbais e filosóficas que envolvem a produção de sentidos. No caso da base analítica peirciana, a análise do signo é enxergada como produto de uma operação mental abstrata que, distinta da matriz saussureana (a pensar principalmente na dicotomia langue e parole), dirige-se para muito além das palavras e seus sons, envolvendo fundamentalmente os signos/imagens em relações com os objetos por eles representados num 


\section{Eu, Yayoi Kusama, que pintei minha obliteração, minha obsessão e minhas fobias}

processo de significação arrolado às categorias de "ícone", "índice”e "símbolo" (PEIRCE, 2008, p. 66).

Desse percurso, apreendido ao gigantismo de tamanhos esforços empenhados ao longo do tempo em busca de uma arquitetura para a Semiologia e de suas consequentes nomenclaturas, resultados evidentes são os movimentos que ora se distanciam, ora rompem de forma irreconciliável com essas duas principais linhas seminais referidas à compreensão de diversas produções humanas quanto à ordem do signo. Como vem a ser o caso - emparelhado aos acontecimentos posteriores a 1968 - do embate entre a semiologia barthesiana e a intericonicidade de Jean-Jacques Courtine. Isso, em razão da inserção da imagem no campo discursivo advir, primeiramente, das elaborações discursivas que se expandem dada a globalização crescente, e em segundo, ela se tornar objeto de análises (restritas e/ou enviesadas) na busca de virtudes capazes de fazer avançar os domínios epistemológicos da $\mathrm{AD}$ para além do território linguístico.

O primeiro deles, Roland Barthes (1915-1980), filósofo, crítico literário, linguísta e semiólogo, foi um dos principais representantes do pós-estruturalismo francês. Influenciado pela obra saussureana, completou seus estudos liceais eacadêmicos na Université de Paris (Letras Clássicas, 1932; Gramática e filosofia, 1943)e trabalhou para o Centre Nacional de la Recherche Scientifique, o CNRS, e entre os anos 1952 e 1959. Perfilada também pela Semiótica, a obra barthesiana, resumida e essencialmente, em sua primeira fase compreendia o processo de significação estabelecido por dois movimentos, o "denotativo" e o "conotativo" (2009), alocando significação num processo de percepção superficial e simples. Já a sua segunda fase ele se deteve nas "mitologias" (2010); um sistema de códigos, conjuntos ideológicos, transmitidos e absorvidos para/por nós desapercebidamente como padrões, razão que possibilitava e viabilizava, por fim, o uso de veículos de comunicação com fins de persuasão. Dentre suas obras destacam-se $O$ Grau zero da Escrita (1953), Mitologias (1957), além de, postumamente, A Câmara Clara (1980), O Óbvio e o Obtuso (1982) e O Rumor da Língua (1984).

Logo, semiólogo focado na comunicação e atuando em tempos de multimídias, colagens, bricolagens e publicidade arraigadas - tais como as capas da revista francesa Paris Match, para Barthes, a força das múltiplas linguagens do mundo contemporâneo também 


\title{
Eu, Yayoi Kusama, que pintei minha obliteração, minha obsessão e minhas fobias
}

demandava uma reforma linguística/semiológica no establishment acadêmico, isto é, reforma mais num sentido de convergências e não de rupturas epistemológicas. Para tanto, a semiologia barthesiana amparada na base sígnica saussureana "significante" e "significado" (2006) sobremodo apresenta o mito como um "sistema tridimensional semiológico" (1957) a ser operado diante da análise literária, cinematográfica, televisiva e fotográfica. Nessa esteira, assim encontramos no mito o

\begin{abstract}
esquema tridimensional [...]: o significante, o significado e o signo [noqual] o mito é um sistema particular no qual se constrói a partir de um canal semiológico que existe antes dele: é um sistema semiológico segundo. O que é signo (quer dizer o total associado de um conceito e de uma imagem) no primeiro sistema, torna-se um simples significante no segundo. É preciso aqui relembrar que as matérias da palavra mítica (língua propriamente dita, fotografia, pintura, cartaz, ritual, objeto, etc.) por mais diferentes que elas sejam no início, assim em que elas são inseridas pelo mito, se direcionam a uma pura função significante: o mito vê apenas nelas uma matéria primeira; sua unidade, elas são reduzidas tão simplesmente ao status da linguagem (BARTHES, 2010, p. 227) ${ }^{13}$.
\end{abstract}

Através de suas mitologias, Barthes rejeita os caminhos epistemológicos mais percorridos de sua época se lançando à tarefa de decifrar - controversamente - o signo expressivo nos estudos das linguagens verbais, narrativas e metanarrativas. $\mathrm{O}$ signo, dessa maneira, para Barthes se atrela desde os simbolismos às mais singelas reproduções presentes a todo o momento nas elaborações discursivas da sociedade. É entendido como objeto artístico, "obra" e "mecanismo" (1957) produtor de sentido. Nessa acepção, a compreensão desses processos, para Barthes, estava arrolada à compreensão das chaves que abririam as portas da comunicação eficiente, ou dos jogos de manipulação discursivos via um entendimento semiótico/semiológico.

Todavia, sobre o postulado barthesiano, embora o mérito reconhecido à Barthes pelo seu interesse dos estudos semiológicos - a saber, desde seu texto inaugural $A$ retórica da imagem (1964) até as próprias formulações a propósito da imagem, tais como "o ob-

13 Tradução nossa de: [on retrouve dans le] mythe le schèma tridimensionnel [...]: le signifiant, le signifié et le signe [...] le mythe est um systhème particulier en ceci qu'il s'édifie à partir d'une chaîne sémiologique qui existait avant lui: c'est un système sémiologique second. Ce qui est signe (c'est-à-dire total associatif d'un concept et d'une image) dans le premier système, devient simple signifiant dans le second. Il faut ici rappeler que les matières de la parole mythique (langue proprement dite, photografie, peinture, affiche, rite, objet, etc.), pour différents qu'elles soient au départ, et dès lors qu'elles sont saisies par le mythe, se ramènent à une pure function signifiante: le mythe ne voit en elles qu'une même matière première; leur unité, c'est qu'elles sont réduites toutes au simple statut de langage (BARTHES, 2010, p. 227). 


\section{Eu, Yayoi Kusama, que pintei minha obliteração, minha obsessão e minhas fobias}

tuso", o "terceiro sentido" (1982) e ainda o "punctum" e o "studium" em A câmara clara (2015), ao se ocupar com a entrada da semiologia para dentro do campo da Análise do Discurso, a fim de expandir seus horizontes epistemológicos, Jean-Jacques Courtine, no entanto, desconsidera a semiologia barthesiana em sua empreitada. Isso, por considerá-la inviável à sua formulação do conceito de intericonicidade. Assim, contrapondo os diferentes aspectos dos níveis das materialidades discursivas imagéticas até então pressupostos segundo a semiologia barthesiana, frente à análise de anúncios publicitários, páginas de jornal ou mesmo películas cinematográficas, Courtine apresenta outra crítica à qual associa toda e qualquer imagem: "não existe imagem que não nos faça ressurgir outras imagens, tenham sido elas outrora vistas ou simplesmente imaginadas" (COURTINE, 2013, p. 43), isto é, isso a partir do conceito de intericonicidade.

Para esta, sendo um sujeito submetido diariamente, desde sua primeira infância, a milhares de imagens que circulam em sua cultura, tais imagens formam um gigantesco mosaico, um arquivo em sua mente, que, por sua vez, promoveria nele, esse sujeito e seu corpo, referências múltiplas decodificadas consciente e inconscientemente. A fim de decifrar o que poderia se esconder por trás de um texto imagético (esse que tem sua formação também num cenário social, dessa forma seguindo associado a certo ícone) tal concepção de texto ainda amparado no fio de uma memória discursiva vai de encontro ao nascimento da intericonicidade, conceito elaborado por Jean-Jacques Courtine.

Um dos integrantes do grupo de Michel Pêcheux, Courtine é professor de antropologia na Université de la Sourbonne Nouvelle (Paris III), professor emérito da University of California (Santa Bárbara), além de titular da cátedra European Studies,da University of Auckland (Nova Zelândia). Seu trabalho, o qual traz para a AD o postulado foucaultiano, perscruta um olhar sobre o corpo, esse tomado como unidade discursiva e ponto capital de sua obra, por sua vez é averiguado historicamente em obras como A História do Rosto (1988); os três volumes de A História do Corpo (2005-2006), e mais recentemente, dirige com Alain Corbin e Georges Vigarello outros três volumes em A História da Virilidade (2015).

Postulada por Jean-Jacques Courtine, a intericonicidade tem sua base nos postulados foucaultianos e também semiológicos; porém, ela está afiliada à semiologia saussureana, aquela 


\section{Eu, Yayoi Kusama, que pintei minha obliteração, minha obsessão e minhas fobias}

fundada em sua concepção do signo linguístico, que nos situa no universo desmaterializado e sistêmico do uso consciente dos códigos edos signos, com seus prolongamentos estruturalistas [mas está em outra,] de inscrição antropológica muito mais antiga, baseada no ajustamento de indícios depositados mais ou menos conscientemente ao longo dos conjuntos significantes, apoiada sobre práticas nas quaiso elemento qualificativo, sendo que a parte subjetiva daquele que produz o indício como aquela de quem o detecta não saberiam ser eliminadas, nem mesmo reduzidas; práticas onde o uso da intuição, a espiadela, o "faro", constituem os elementos essenciais (COURTINE, 2013, p.40).

No sentido exposto por Courtine, se estabelece uma nova aproximação da imagem entre a AD, a Linguística, a Psiquiatria e a Semiologia; uma que colocaria o analista de discurso diante de uma análise empreendida tal qual aos moldes de um Sherlock Holmes - o próprio detetive policial do universo literário de Arthur Conan Doyle (1859-1930). Em outras palavras, emparelhado ao pensamento de Foucault atrás de respostas para os modos de objetivação que transformaram os seres humanos em sujeitos, Courtine, inquieto com o momento em que as ciências humanas seguem conquistadas pelo formalismo quantitativo e pelas pretensões utilitaristas, compreende que os desafios requeridos na decifração do corpo - tal a função policial do detetive de Doyle - desse modo "voltam a conservar à parte humana de nossa existência sua densidade antropológica e sua profundidade histórica, a elucidar o que nos faz sujeitos" (COURTINE, 2013, p. 40).

Mediante a tanto, o exemplo do detetive atrás de indícios (esses, compreendidos no sentido morelliniano do termo, referidos ao "paradigma indiciário" em Carlo Ginzburg, 2014), quer o seja pelos arredores, quer o seja nos corpos das vítimas, segundo Courtine, nos seria mais útil em relação à leitura e interpretação (essa, no sentido freudiano do termo, ou seja, delineada como um “discurso do estranhamento” (MILANEZ, 2015, p. 202) das imagens do que aquele empreendido pela semiologia barthesiana, essa necessitada de signos. Assim, resumidamente, através de uma semiologia inclinada à Fisiognomonia, isto é, "as maneiras de dizer e formas de ver o corpo humano: semiologias da exterioridade, da aparência, do invólucro corporais" (COURTINE, 2013, p. 48) é que Courtine propõe, similar à semiologia médica, que via o exercício sistemático do olhar sobre o corpo, o deslocamento do campo discursivo linguístico para o imagético. 


\section{Eu, Yayoi Kusama, que pintei minha obliteração, minha obsessão e minhas fobias}

Logo, em se considerando no território nas imagens haver existência/referência direta de imagens/ícones fornecidos pelo suporte prévio do 'arquivo iconográfico' que reside no sujeito como um dado de memória discursiva, segundo Courtine, diante de uma análise iconográfica é preciso que se reconheça que não encontramos aí signos (as menor partículas comunicacionais dotadas de sentido) mas sim indícios (elementosqualificativos, conscientes ou inconscientes dos conjuntos significantes compreensíveis pela intuição, pela observação). Desse modo, a promoção a análise da imagem comporta de imediato um impasse na semiologia barthesiana, tendo em vista que a imagem em nada obedece ao modelo da língua. Ou seja, o deslizamento da estrutura dos signos linguísticos sobre a estrutura das imagens não sustenta o caráter discursivo icônico próprio das imagens, tal como esse é apreendido pela intericonicidade.

Observados os movimentos acerca da constituição dos estudos semiológicos em proximidade e distanciamento do signo linguístico na esteira do século XX, conduzimos agora o trato da imagem como objeto de análise da $\mathrm{AD}$ retrocedendo aos acontecimentos decorridos à reforma intelectual francesa dos anos de 1960, inevitavelmente. Duas décadas após os desdobramentos culturais maio de 1968, embora pairassem controvérsias sobre a significação de seus acontecimentos e o espírito revolucionário já tivesse passado de moda, no entanto, não se podia "negar que eles foram um marco importante na história, cujos efeitos ultrapassaram as fronteiras da França e prolongaram-se nas décadas de 70 e 80" (THIOLLENT, 1998, p. 83). O comprova, a exemplo de tais efeitos, o embate semiológico entre Barthes e Courtine no que diz respeito ao avanço dos estudos discursivos diante do desenvolvimento da $\mathrm{AD}$.

Em 1980, por sua vez, o campo teórico da Análise do Discurso era bombardeado por pensamentos reclamando passagem às suas fronteiras epistemológicas. A reforma em questão tratava de uma crítica em favor da expansão dos 'mitigados' e 'rígidos' limites teóricos e metodológicos impostos para a Análise do Discurso, conforme se depreende a leitura de Milton Milanez (2015). Mais precisamente, é para Jean-Jacques Courtine, ministrante da comunicação Quel objet pour l'analyse du discours? (1980) que a Análise do Discurso ainda era "tomada como uma disciplina híbrida, incompleta, feita de muitos 


\section{Eu, Yayoi Kusama, que pintei minha obliteração, minha obsessão e minhas fobias}

compromissos incertos; promessa talvez de uma articulação ausente, comprometedora para o "puro linguísta"” (MILANEZ, 2015, p. 198).

Dentre as propostas de reformulação que tinham como objetivo apontar novos caminhos no interior da Análise do Discurso, ou seja, em seu campo teórico, Nilton Milanez (2015) nos conduz assim outra vez para abril de 1980, quando o "território da Análise do Discurso (doravante AD) se revolvia e construía suas posições" (MILANEZ, 2015, p.197). Em razão de tais reformulações intelectuais, na época acenadaparticipavam do Colloque Materialités Discurisives, sediado na Université Paris X, Michel Pêcheux, Jean-Marie Mandarin, Françoise Gadet, dentre outros intelectuais. O evento, também no qual Jean-Jacques Courtine defendia sua tese Análise do Discurso Político: o discurso comunista endereçado aos cristãos (2009) propunha o debate de "questões essencialmente verbais no nível das formulações linguístico-discursivas [...] em relação aos deslocamentos de fronteiras entre as disciplinas e suas margens" (MILANEZ, 2015, p. 197). Sobremodo, a respeito do embate da $\mathrm{AD}$ visado pelocolóquio, em sua abertura Pêcheux acena que tal evento

delimitava o espaço do encontro de linguistas, historiadores e psicanalistas, cada qual conservando o seu lugar, mas com um objeto comum: a presença da palavra e da escrita, enfim, do discurso no quadro heterogêneo entre história, língua e inconsciente (MILANEZ, 2015, p. 197).

A princípio, então, na comunicação Quel objet pour l'analyse du discours?, a qual visava caminhos futuros para a $\mathrm{AD}$, seus ministrantes Courtine e Mandarin propuseram deslocamentos teórico-conceituais a fim de uma (re)configuração do campo do discurso. Pois, segundo o intuito dos pesquisadores amparados no pensamento foucaultiano, conforme bem observa Milanez, para eles, antes de qualquer coisa era preciso que uma disciplina fosse compreendida como

princípio de controle da produção de certos discursos, que lhes fixa limites pelo jogo de uma identidade que tem a forma de uma reatualização permanente de suas regras - uma disciplina que sabemos, por praticá-la inquieta com seu objeto (MILANEZ, 2015, p. 198).

Estabelecidas as premissas do cenário intelectual dos anos de 1980 quanto à pretensão de se alçar novos rumos para a disciplina da $\mathrm{AD}$, por sua vez, Milanez salienta em 


\section{Eu, Yayoi Kusama, que pintei minha obliteração, minha obsessão e minhas fobias}

especial a perspectiva de Jean-Jacques Courtine sobre tal reformulação para a AD: a de evidenciar o trabalho com a história e sua constitutividade para as produções discursivas. Produções discursivas iconográficas, inclusive. Nessa linha, Milanez retoma o entrelaçamento da perspectiva de Courtine ao aporte arqueológico foucaultiano, apontando em específico para o princípio sinalizador de que um texto primeiro trará sempre a presença de um texto segundo, isto é, que "um enunciado tem sempre as margens povoadas de outros enunciados" (FOUCAULT, 2010, p. 110). É, portanto aí, para Milanez, que se encadeiam os pensamentos de Foucault e Courtine quanto à "noção da repetição como condição de possibilidade da $\mathrm{AD}$, referindo-se a repetição nos discursos de um conjunto de marcas formais, é claro, também no campo do verbal” (MILANEZ, 2015, p. 198).

Uma vez conceituado o princípio que atribui à $\mathrm{AD}$ sua “"força arqueológica', o que fornecerá a forma para modalidades da existência do discurso" (MILANEZ, 2015, p. 198), no que diz respeito à formulação de intericonicidade de Courtine, essa também se torna admissível no escopo dos estudos das análises das visualidades relacionadas à $\mathrm{AD}$, pois, em seu turno, Courtine toma

o arcabouço foucaultiano como condição de possibilidade para o estudo da materialidade da imagem na $\mathrm{AD}$, sobretudo, no que se refere à sobreposição de imagens, suas memórias, e a repetição dessas imagens e seus discursos por meio da noção de intericonicidade (MILANEZ, 2015, p. 198).

Logo, a noção de intericonicidade é sublinhada por Courtine a partir do conceito de memória discursiva, isto é, como uma perspectiva conceitual e metodológica no campo da Análise do Discurso. Dessa maneira, pensando num "modelo de discurso que urgia referir a imagem. Mas ao discurso no sentido foucaultiano, isto é, em um sentido onde o discurso pode ser um fragmento de imagem como centelha de linguagem" (COURTINE, 2013, p. 42), Courtine propõe que se

a ideia de memória discursiva implica que não existem discursos que não sejam interpretáveis sem referência a uma tal memória, que existe um "sempre já" do discurso, segundo a fórmula que nós empregamos então para designar o interdiscurso [...] [e]u diria a mesma coisa da imagem: toda imagem se inscreve em uma cultura visual, e esta cultura supõe a existência junto ao indivíduo de uma memória visual, de uma memória das imagens onde toda imagem tem um eco (COURTINE, 2013, p. 43). 


\section{Eu, Yayoi Kusama, que pintei minha obliteração, minha obsessão e minhas fobias}

Nesse sentido, Courtine estatui pontualmente haver em cada imagem um "'sempre já" da imagem". Isso implica dizer, portanto, que tal "memória das imagens externas" pode se equivaler em igualdade à "memória das imagens internas" as quais surgem, por sua vez, "despertadas pela percepção exterior de uma imagem” (COURTINE, 2013, p. 43). Assevera-se, nessa medida, que na intericonicidade se relacionam simultaneamente imagens externas com imagens internas, ou seja, um encadeamento de imagens "de lembranças, imagens da rememorização, imagens das impressões visuais estocadas pelo indivíduo [, pois,] [n]ão existe imagem que não nos faça surgir outras imagens, tenham sido outrora vistas ou simplesmente imaginadas" (COURTINE, 2013, p. 43).

Distanciada a intericonicidade da semiologia barthesiana, deve-se ainda salientar que, diante da abordagem das imagens pelo caráter discursivo da intericonicidade, essa, igualmente formulada junto às esteiras da $\mathrm{AD}$ foucaultiana, da Psiquiatria e da Semiologia, também possui em esse processo formulador raízes com o pensamento do historiador de arte alemão Hans Belting (1935-), no que se refere à perspectiva antropológica das imagens, finalmente. De Belting, em Pour une anthropologie des imagens (2002) por sua vez, no centro da concepção teórico-metodológica da intericonicidade é somado um elemento catalisador capaz da apreensão da cultura visual, da memória, das imagens externas e das imagens internas; um elemento sobre o qual se incidem pistas a fim de serem apreendidas pelo exame médico-investigativo, tão aguçadamente como o faria um Sherlock Holmes: o corpo. Encontra-se nesse, compreendido aqui como uma unidade discursiva, a ideia de que

toda a imagem deve ser analisada a partir do médium, isto é, do suporte material que é o seu, médium visto, mas igualmente, a partir de um corpo olhando. E a particularidade do corpo pode ser um médium também, isto é, que ele é o médium, o suporte das imagens internas (COURTINE, 2013, p. 43-44).

Por tais razões, operar o conceito da intericonicidade significa sobremaneira relacionar conexões de imagens. Dessa articulação, por sua vez, pretende-se reconstituir os vínculos de umas imagens às outras, os quais, em seu turno, estabelecem seu sentido com os ícones de uma determinada cultura com determinados indivíduos que compartilham de sua memória. Nas palavras de Courtine, tal procedimento torna-se possível pelo 


\section{Eu, Yayoi Kusama, que pintei minha obliteração, minha obsessão e minhas fobias}

“ajustamento, pela detecção no material significante da imagem, pelos indícios, pelos rastros que outras imagens ali depositaram, e pela reconstrução, a partir destes rastros, da genealogia das imagens de nossa cultura" (COURTINE, 2013, p. 44).

A isto, assinala-se finalmente que as

imagens exteriores ao sujeito, como quando uma imagem pode ser inscrita numa série de imagens, uma arqueologia, à maneira de um enunciado numa rede de formulações junto à Foucault [- séries enunciativas]; mas também imagens externas, que supõem a consideração de todo o catálogo memorial da imagem junto ao indivíduo, e talvez também os sonhos, as imagens vistas, esquecidas, ressurgidas ou até fantasiadas, que assombram o imaginário [- o arquivo] (COURTINE, 2013, p. 44).

Isso posto, da apresentação do nascimento da AD desde Pêcheux - disciplina que visa à produção de instrumentos capazes de descrever e analisar uma nova língua, uma nova história e um novo sujeito, enfim apreendemos: seu desenvolvimento em três fases (AD-1: metáfora da maquinaria discursiva-estrutural; AD-2: formação discursiva, AD-3: heterogeneidade). A partir da necessidade de expansão do campo do discurso na disciplina da $\mathrm{AD}$, bem como vislumbrada a perspectiva da AD foucaultiana(arqueológica, genealógica e ética) a partir da resposta aos eventos de sua esteira histórica, dos anos de 1960 aos anos de 1980, foi abrangido o seu entrecruzamento com os estudos da Semiologia, em especial perfilando a obra de Barthes e, mais recentemente, de Courtine que trouxe para seu escopo a noção de intericonicidade.

Uma vez pontuados os aspectos basilares do surgimento da AD, bem como o seu entrelaçamento com Michel Foucault e o nascimento da intericonicidade, passemos agora a estabelecer, precisamente, os seguintes pressupostos arquegenealógicos: arqueologia, discurso, documento, monumento, Nova História, sujeito, enunciado, arquivo, formações discursivas, poder, sujeito, subjetivação, objetivação, relações de poder, microfísica do poder, assujeitamento e dispositivo. No presente trabalho, inspirados no gesto analítico sobre os discursos estudados em Eu, Pière Rivière...(2003), esses moverão a análise sobre a persona/corpo de Yayoi Kusama, que assim também apresentará um seguimento analítico perfilado pelos critérios da intericonicidade. 


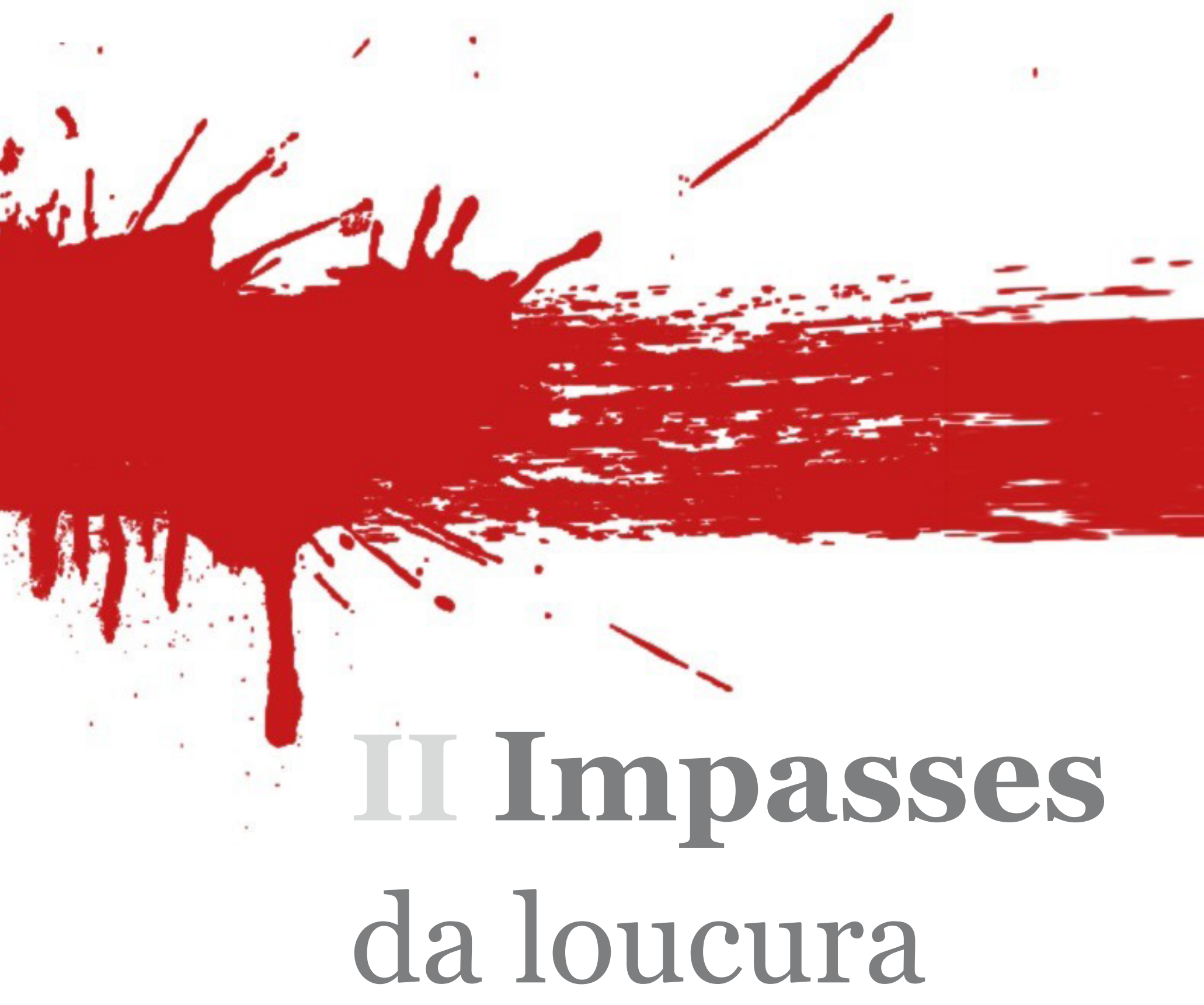




\section{Arqueologia}

"Escrever é se transformar, é desprender-se de si mesmo, dissociar-se de si mesmo. Se eu já soubesse onde estava indo, não escreveria." 14

Michel Foucault

Antes de direcionarmos nossa atenção aos conceitos arqueológicos referidos, não poderíamos deixar de realçar, brevemente, alguns dados relevantes da vida que remontam à ordenação da escrita do arquegenealogista cujo pensamento orienta-se a nossa pesquisa. A mais completa fonte bibliográfica sobre Foucault é aquela publicada em 1989 por Didier Eribon. Consideram-se fiéis também as entrevistas publicadas nos quatro volumes de Dits et Écrits de 1976 a 1988; uma cronologia detalhada que segue nas primeiras páginas da obra citada, nas quais permeiam, bem como ele mesmo reconhece, aspectos de sua vida intimamente ligada com sua obra.

Nascido em uma família burguesa em 15 de outubro de 1926, na medieval Poitiers, cidade ao Sudoeste da França, Michel Foucault, negligenciando a profissão de seu pai foi cursar o prestigiado Lycé Henri-VI. Aos 20 anos principia seus estudos acadêmicos na École Normale Supérieure em 1946. Lá conhece e mantém contato com Pierre Bourdieu, Jean-Paul Sartre, Paul Veyne, entre outros pensadores. Aos 22 anos foi internado pelo pai, o famoso cirurgião Malapart, na instituição psiquiátrica Sainte-Anne após uma tentativa de suicídio. Aos 25 anos conclui sua Licenciatura em Psicologia e recebe seu diploma em Estudos Superiores de Filosofia, com uma tese sobre Hegel, sob orientação do pensador hegelianiano Jean Hyppolite. Nos anos de 1970, é convidado a ocupar a cadeira de seu mentor no Collège de France. Na mesma época, nos Estados Unidos da América, conhece a comunidade gay californiana. Nos anos de 1980 é uma das primeiras vítimas a contrair o vírus HIV. Aos 58 anos morre, em 25 de junho de 1984, consagrado como o filósofo que "matou" o homem contemporâneo.

Conforme estabelecemos anteriormente em nossas preliminares com Michel Foucault, colocar-se diante desse autor de tantos estilos, temas, teses e retóricas ampla-

14 Citação de Foucault por Geoffroy de Lagasnerie em Foucault contre lui-même. Frame 2:22min. / 2:31min. Documentário. Direção de François Caillat. The factory, Art France. 54 min. França, 2014. 


\section{Eu, Yayoi Kusama, que pintei minha obliteração, minha obsessão e minhas fobias}

mente expressivas e disseminadas é o mesmo que percorrer uma ideia permanente que se contradiz em si mesma, que corrige a si mesma, e que se constitui para ser questionada em seu próximo texto, irrefutavelmente. Em resumo, acompanhar o arcabouço foucaultiano é, segundo entende o filósofo e sociólogo francês Geoffroy de Lagasnerie (1981-), compreender que ele "toma como ponto de partida de seus livros oslivros anteriores, para afastar-se deles. Então ele sempre escreve sobre si mesmo, em um diálogo consigo mesmo. Ou seja, ele parte de onde parou para se tornar outra coisa." 15

De interesse para a $\mathrm{AD}$, relembramos que tomamos como unidade de sua obra o questionamento de nossa identidade atual refletida com base nos modos de objetivação que transformam os seres humanos em sujeitos. Dessa perspectiva compreendemos, em consonância à colocação de Inês Lacerda Araújo que

Foucault pensa para a nossa época, a fim de que possamos, talvez um dia, nos constituir de outro modo, acolhendo e produzindo novasformas de relacionar a verdade, saber e poder, novas formas de subjetividade que relativizem a carga da verdade extraída exclusivamente sob a forma da norma, da vigilância e do constrangimento em buscar, por intermédio da ciência, algum ego perdido (ARAÚJO, 2008, p. 9).

Logo, é de interesse para a nossa pesquisa - em expondo a reflexão acima acerca do embate contemporâneo que enquadra a subjetivação pressuposta ao sujeito pelo aporte foucaultiano na análise dos processos, poderes e saberes - estabelecermos a personal corpo de Yayoi Kusama como uma posição-sujeito "artista-louco" no establishment das artes contemporâneas. Para tanto, se faz necessário sublinhar os conceitos presentes na obra foucaultiana que mobilizarão tal persona/corpo em nossa análise; os quais listaremos a seguir.

De A Arqueologia do saber, de 1969, tomamos as formulações em torno dos seguintes conceitos: arqueologia, discurso, sujeito, documento, monumento, Nova História, enunciado, arquivo, formações discursivas. Corroborando esses conceitos-chave arqueológicos, nesse seguimento do capítulo trataremos também do conceito de acontecimento, esse na Ordem do Discurso (2009), além do conceito de memória discursiva, de Jean-Jacques Courtine (1981); todos preceitos caros à $\mathrm{AD}$, por sua vez. Os conceitos arqueológi-

15 Citação de Foucault contre lui-même. Documentário. Direção de François Caillat. The factory, ArtFrance. 54 min. França, 2014. 


\section{Eu, Yayoi Kusama, que pintei minha obliteração, minha obsessão e minhas fobias}

cos compõem, para Foucault, um arcabouço de instrumentos com os quais se pode compreender quem somos nós hoje. Trata-se de conceitos que, segundo Foucault os articulava, demonstravam que é no próprio discurso, a saber, em suas diversas materialidades (textos, arquitetura, pinturas, imagens...) que se produzem sentidos, objetos, subjetividades e sujeitos, historicamente.

Pesquisador filiado ao pensamento de Foucault, como visto, Jean-Jacques Courtine expressa em seu livro Déchiffrer le corps - Penser avec Foucault (2013), a partir da ótica de Deleuze, o método arqueológico como um entrecruzamento entre as coisas e as palavras. Mais precisamente, essas coisas são vistas de maneiras diferentes em diferentes épocas e palavras, posto que os enunciados sofrem transformações de acordo com tais mudanças. Noutras palavras, o método arqueológico empreende buscar os saberes ${ }^{16}$ tomando-os a partir do encontro do visível e do legível/dizível/enunciável sobre um determinado objeto. Na acepção que se apreende, o discurso - lugar de saberes - é compreendido como cruzamento dado entre os campos linguístico e histórico, mostrando, dessa maneira, o modo como uma sociedade específica e um tempo específico visualizava, pensava e, evidentemente, falava sobre os objetos de seus pensamentos.

A partir daí, é necessário esclarecer que a relação compreendida entre o sujeito e o discurso não é a mesma que aquela estabelecida entre o falante e a língua. Isso porque nem a língua, tão pouco a psicologia desse sujeito que as formula a fim de expressar-se são o objeto de estudo da AD. As intenções pressupostas na origem dos discursos empregados também não são de interesse da $\mathrm{AD}$; ao contrário, ela refuta a relação lógica entre os discursos e o nível do real e também do psicológico. A seu ver, a prática arqueológica de interesse a AD não trata o discurso

como documento, como signo de outra coisa, como elemento que deve sertransparente, mas cuja opacidade importuna é preciso atravessar frequentemente para reencontrar, enfim, aí onde se mantém à parte, a profundidade na qualidade de monumento. Não se trata de uma disciplina interpretativa [a prática arqueológica]: não busca um "outro discurso" mais oculto. Recusa-se a ser alegórica (FOUCAULT, 2010, p. 157).

16 Para Foucault, o saber é um domínio envolvido na ficção e na reflexão, o qual faz parte de narrativas, é inerente aos regulamentos institucionais e figura em decisões políticas, etc. O saber é "o espaço em que o sujeito pode tomar posição para falar dos objetos de que se ocupa em seu discurso" (FOUCAULT, 2010, p.204). Logo, não só a posição ocupada pelo sujeito é determinada pelo saber, como o sujeito também é dependente do saber, além de ser dominado e subjetivado por ele, sendo o saber a condição e o limite para a existência da singularidade e/ou dispersão do sujeito. 


\section{Eu, Yayoi Kusama, que pintei minha obliteração, minha obsessão e minhas fobias}

Em síntese, cabe antes compreender o discurso que ocupa seu próprio espaço e que irrompe segundo suas próprias leis e em sua especificidade. Ou seja, os discursos naAD foucaultiana não são causa daquilo que os procedem, nem são resultados daquilo que os precedem. Estão mais para um acontecimento singular no "jogo das regras [...] irredutível a qualquer outro [discurso]" (FOUCAULT, 2010, p. 157). Com isso, diante das variáveis desse jogo em que se apreendem ruptura e transformação históricas (as quais viabilizam ao discurso o seu nó singular), convém reconsiderar, nesse processo, os conceitos de tempo e de Nova História.

Na perspectiva teórico-metodológica que se inscreve, a apreensão do tempo, portanto, não é linear; dado que este é compreendido em suas rupturas e descontinuidades. Dito de outro modo, a história aqui não é mais abordada como uma evolução progressiva - tal qual sugeriria o olhar biológico da vida humana; isso no que diz respeito considerar uma determinada época como sendo consequência ou resultado direto daquela que a precedeu, respectivamente. $\mathrm{O}$ enfoque aqui não recai sobre a interpretação de documentos; empreende-se, em vez disso, um gesto arqueológico nessa história das transformações, essa que então se organizada como um "emaranhado de descontinuidades sobrepostas" (FOUCAULT, 2005, p. 293).

Como remate desse processo, verifica-se tanto o deslocamento da histórica“"escrita por seus vencedores" àquela lida através dos acontecimentos que recebem visibilidade, como também a visibilidade a partir de séries de documentos outrora esquecidos, ou ainda, séries demonstrando que a "inversão de uma tendência econômica é muito mais importante do que a morte de um rei” (FOUCAULT, 2005, p. 292). Com isso, é imprescindível considerar a Nova História compreendo-a, primeiro, em sua interdependência com o discurso, e, por conseguinte, que, fatalmente, não há nada que preexista a ele.

Importante também é admitir que devemos reconhecer como ilusão uma história verdadeira, admissível e real criada pelos historiadores nos documentos históricos. Esses, abrangidos como discursos, tratam-se, contudo, de um efeito de verdade que se produz na/ pela sua materialidade. Materialidade essa produzida pela língua conforme suas regras de uso, mesmo em suas formas estruturais, além de ponderar inclusive a legitimidade atri- 


\section{Eu, Yayoi Kusama, que pintei minha obliteração, minha obsessão e minhas fobias}

buída à(s) 'verdade(s)' de acordo com as instituições que a(s) produz(em). É nesse sentido que se deve compreender como uma ilusão (não fundamentalmente intencional) aquilo que reconhecemos como história verdadeira, admissível e real criada pelos historiadores - estes, não obstante, igualmente constituídos discursivamente.

Ora, nessa medida, um documento é um recorte no qual uma seleção de informações exclui outras, essencialmente. Assim, apaga-se assim a probabilidade de existência de outros recortes, de outras representações históricas, bem como outros sujeitos, vozes e demais verdades. Esse é o enfoque arqueológico dado ao documento, visto como monumento: enquanto o documento é considerado neutro e suas condições de produção não são questionadas, em contrapartida, um documento em qualidade de monumento pressupõe, inevitavelmente, intencionalidade. Ou seja, sua existência pressupõe uma finalidade: a representação de um - e não outro - aspecto histórico; de um dado acontecimento - e não outro - à sobrevivência na memória de uma determinada sociedade. O que esse processo destaca é, portanto, o questionamento da história que nos é contada; é duvidar de que não exista intencionalidade no seio da história.

Contudo, apreender a existência de tais recortes discursivos nessa tessitura histórica significa primeiramente dizermos que é papel do historiador promover um recorte discursivo, então, uma análise debaixo da "espuma da história" (FOUCAULT, 2005, p. 291) para "descobrir esse estrato escondido de acontecimentos difusos, "atmosféricos", policéfalos que, afinal, determinam, e profundamente, a história do mundo" (FOUCAULT, 2005, p. 292). Em segundo, faz-se necessário admitir que esses recortes sejam determinados conforme impõem as condições sócio-históricas de suas existências. Para tanto, Foucault pergunta "como apareceu um determinado enunciado, e não outro em seu lugar?" (FOUCAULT, 2010, p. 30). Desse modo, sendo esse questionamento o primeiro gesto feito na análise discursiva, abordamos ai o discurso em seu momento de irrupção de acontecimentos que, ligando-o com sua historicidade, o torna único e o acaba por distingui-lo de outros enunciados. Entende-se, assim, o lugar até então ocupado por língua, proposições e falantes, agora tomado por discursos, enunciados e sujeitos.

No que diz respeito à linguagem para a $\mathrm{AD}$, atualmente, não se pode perder de vista que sua concepção difere daquela tradicional referente aos estudos linguísticos. Re- 


\section{Eu, Yayoi Kusama, que pintei minha obliteração, minha obsessão e minhas fobias}

tomando o sujeito cartesiano ${ }^{17}$ de Descartes, sabe-se que a este se atribui a ilusão de que ele poderia influenciar a língua ao passo em que ele seria a fonte dos seus próprios dizeres. Logo, teria o controle pleno dos sentidos que produz. Já para a concepção de 'novo sujeito' da $\mathrm{AD}$, o sujeito tanto produz discursos na medida em que é simultaneamente produzido por eles; isto é, assim ele é compreendido como sujeito e objeto. Não referenciamos na $\mathrm{AD}$, portanto, o sujeito em suas carnes e em suas atividades corriqueiras como trabalhar, falar, aquele que se exercita. Trata-se um sujeito em cuja voz embarcam sempre outras vozes, essas vindas de diferentes posições (concepção da heterogeneidade) e que podem dessa maneira complementá-lo ou contradizê-lo. Como se percebe, a AD refuta a concepção cartesiana do sujeito.

Agreguemos à discussão o conceito de enunciado - o elemento mínimo do discurso, Foucault o enquadra o determinado por todas as coisas que ele não é. Como resultado de sua articulação, por fim, compreendemos que o enunciado é a função e a condição de existência das unidades linguísticas e outras materializações do discurso. A partir disso, sendo o sujeito discursivo uma posição vazia e preexistente ao enunciado, condicional a sua(s) existência(s), desse modo é a sua posição (num determinado campodiscursivo) aquela que define o efeito de sentido produzido pelo sujeito. Nesse passo, a posição-sujeito é constituída a partir do cruzamento entre a memória discursiva com outras estruturas discursivas, e assim recebe, em sua atualidade, novos sentidos.

A guisa de exemplo: a palavra 'artista' (a estrutura) em seu sentido dicionarizado é frequentemente usada como denominação para uma pessoa que cultiva as belas-artes, que possui habilidade ou vocação artística, ou aquele que é célebre. Já a palavra artista (o enunciado), em seu turno, requer à memória discursiva o imaginário sobre o artista; o qual reverberará especificadamente com certo tempo e lugar, ou seja, com uma condição sócio-histórica.

Prontamente, é nisso que Foucault consiste dizer que o enunciado é o elemento mínimo do discurso em se tratando de algo que "nem a língua nem a razão podem

17 Remetendo o adjetivo 'cartesiano' à frase "Cogito, ergo sum" ("Penso, logo existo") cunhada no livro de Descartes Discurso do Método de 1637, trata-se do sujeito uno, fixo e razoável; o modelo pressuposto ao ser humano que remonta o ideário do século das Luzes. 


\section{Eu, Yayoi Kusama, que pintei minha obliteração, minha obsessão e minhas fobias}

esgotar inteiramente" (FOUCAULT, 2010, p. 31). Porém, esse algo só encontra sua materialidade e se torna conteúdo na língua e noutras materializações do discurso; daí se compreende afirmar que tanto o enunciado como o discurso preexistem à sua materialização e não são propriamente de ordem linguística, tendo em vista, sobremodo que

em seu modo de ser singular (nem inteiramente linguístico, nem exclusivamente material) o enunciado é indispensável para que se possa dizer que há ou não frase, proposição, ato de linguagem [...]. O enunciado não é pois uma estrutura, (isto é, um conjunto de relações entre elementos variáveis, autorizando assim um número talvez infinito de modelos concretos) [...] ele não é, em si mesmo, uma unidade, mas sim uma função que cruza um domínio de estruturas e unidades possíveis e que faz com que apareçam, com conteúdos concretos, no tempo e no espaço (FOUCAULT, 2010, p. 97-98).

Tão pouco ainda, sendo um enunciado também simultaneamente singular e repetível, logo um enunciado não pode existir sem outros enunciados com os quais se relaciona. Posto que ele irrompe como acontecimento singular, ele assim o é em razão e estar envolvido em vários tipos de relações com outros enunciados oriundos de outros discursos, desse modo, comentando-os, transformando-os, ou ainda opondo-se a eles. Portanto, um enunciado se delineia "em um campo enunciativo onde tem lugar e status, que lhe apresenta relações possíveis como o passado e que lhe abre um futuro eventual" (FOUCAULT, 2010, p. 111-112). Noutras palavras, podemos associar um enunciado como um "nó em uma rede" de discursos, o qual, quando analisado, revela tanto a posição do sujeito que o produziu; também os efeitos resultantes de tal posicionamento; bem como as condições sócio-históricas que possibilitaram que esse enunciado acontecesse e se materializasse dessa respectiva maneira, e não de outra.

Oposto ao enunciado, o maior elemento do discurso é o arquivo. E, estabelecer a relação entre enunciado e arquivo, a saber, explicar as regras e condições de suas formulações, a isso se refere o emprego do método arqueológico na análise e interpretação da Nova História ${ }^{18}$. Para Foucault, o arquivo é a massa de todas as coisas ditas efetivamente

18 Frisamos que se diferem os conceitos foucaultiano de arqueologia e o conceito da Nova História. Embora Foucault tivesse uma ligação irrecusável com os historiadores da Nova História, sabe-se, no entanto, que a empreitada desse conjunto de pesquisadores do campo da história não é compatível àquela da arqueologia foucaultiana. O método arqueológico se aproxima da Nova História por recusar à unidade, a continuidade, a origem, a causalidade, etc.; porém, em seu turno, elabora sua própria epistemologia ao fornecer instrumentos para a pesquisa feita pelo historiador-arqueólogo; esse que não analisa documentos, mas sim monumentos. 


\section{Eu, Yayoi Kusama, que pintei minha obliteração, minha obsessão e minhas fobias}

sobre todos os enunciados: coisas enunciadas por certos sujeitos, coisas vindas de certas instituições, coisas faladas em certas condições. Nessa medida, o arquivo jamais cessa seu crescimento e não se pode apreendê-lo em sua totalidade, consequentemente. Assim sendo, se pudéssemos apreender o presente do arquivo, ele seria vislumbrado como um acúmulo de incontáveis enunciados, ou seja, um "todo" dos já-ditos e, simultaneamente, um "todo" das lacunas de possibilidades dos enunciados ainda-não-ditos que podem ser efetivamente produzidos no futuro, conforme as relações estabelecidas entre os enunciados. Em síntese, o horizonte desse "todo" de possibilidades faz do arquivo ser, primeiramente, "a lei do que pode ser dito" (FOUCAULT, 2010, p. 147) e, por conseguinte, "o sistema geral de formação e da transformação dos enunciados" (FOUCAULT, 2010, p. 148).

Ao perfilarmos arquivo e enunciado encontramos as formações discursivas. Em linhas gerais, as formações discursivas (FD) mostram as filiações estabelecidas entre os enunciados. Nesse sentido, uma FD é compreendida como uma "lei de coexistência dos enunciados" (FOUCAULT, 2010, p. 132). Logo, uma FD resulta das relações que se estabelecem entre um enunciado e outro. Todavia, cumpre observarmos que ainda que uma formação discursiva soe como um sistema fechado, paradoxalmente ela também é inerentemente aberta, apresentando rupturas que permitem penetrar nelas outras formações discursivas por meio de seus enunciados - esses que jamais existem sozinhos. Nesse sentindo, podemos entender a unidade de uma formação discursiva como a regularidade temática; seus objetos, seus conceitos, isso considerando ainda a semelhança de maneiras em que esses figuram dispersos nos discursos. Corroborando a questão, nas palavras de Courtine, apreende-se uma FD em sua dispersão regular através dos tempos, espaços e autores dos textos ao se delinear

\footnotetext{
um fio tênue, mas tenaz, que atravessa e tece a tela das palavras e das imagens, um discurso "transverso, indefinidamente iterado, que permite "enunciações as mais dispersas" no seio desse amplo corpus: este fio "interdiscursivo", é o da formação discursiva ela mesma, este paradigma da expressão que atravessa as textualidades [...], as religa, as ordena, garante a passagem de uma à outra, prestando assim simultaneidade da unidade e dispersão de uma parte inteira de saberes (COURTINE, 2013, p. 24)
}

Cabe prosseguirmos com a perspectiva arqueológica para o acontecimento. $\mathrm{Na}$ arqueologia, enunciado e discurso são considerados acontecimentos. Compreende-se 


\section{Eu, Yayoi Kusama, que pintei minha obliteração, minha obsessão e minhas fobias}

nisso que o deslocamento do conceito do acontecimento faz-se necessário aqui, visto que o nível do discurso não é material. Sendo que o discurso é apenas materializado, por sua vez, o acontecimento não é algo que receba substância. Isto é, para Foucault, o acontecimento

não é nem substância nem acidente, nem qualidade, nem processo; o acontecimento não é da ordem dos corpos. Entretanto, ele não é imaterial; é sempre no âmbito da materialidade que ele se efetiva, que é efeito; que ele possui seu lugar e consiste na relação, coexistência, dispersão, recorte, acumulação, seleção de elementos materiais; não é o ato nem a propriedade; produz-se como efeito de e em uma dispersão material (FOUCAULT, 2009, p. 57-58).

Define-se o acontecimento como uma irrupção simultaneamente pontual e dispersa, que é singularmente definida pelo lugar e momento em que ele surge. Sendo o acontecimento ao mesmo tempo um e muitos, ele "possui seu lugar consistente na relação, coexistência, dispersão, recorte, acumulação e seleção de elementos materiais" (FOUCAULT, 2009, p. 57).

Em corroborando os conceitos arqueológicos propostos, oportuno se torna delinearmos nesse passo o conceito de "memória discursiva" cunhado por Jean-Jacques Courtine em sua tese de doutorado Análise do Discurso Político: o discurso comunista endereçado aos cristãos (1981). Courtine o estabelece tomando como base a reflexão de Focault diante do campo associativo do enunciado. Grosso modo, a memória discursiva faz referência àquilo que - no nível do discurso - possibilita a produção de sentidos.

Assim, para a $\mathrm{AD}$, a memória discursiva diz respeito ao atravessamento ou ao apagamento de certo enunciado na história. Nela se fixam uma seleção de discursos os quais refletem a vontade de saber coletiva de uma sociedade; a memória discursiva dessa maneira não se refere, certamente, ao conjunto de recordações de toda a vida de um sujeito. Está mais para um histórico da sociedade constituído por um conjunto de determinadas materialidades, no qual reside força, regularidade; uma positividade que distingue os discursos os ligando através do tempo, e que, por conseguinte, mostra a repetição de um mesmo elemento, uma mesma unidade dos/nos discursos que transcende as unidades do livro de do texto. 


\title{
Eu, Yayoi Kusama, que pintei minha obliteração, minha obsessão e minhas fobias
}

Enfim, vale dizer que o a priori histórico (FOUCAULT, 2010) é a lei que ordena a vida e a sobrevivência dos discursos, no espaço e no tempo; é a ordenação estabelecida pelos discursos já-ditos os quais, apenas pelo intermédio do tempo mostram as regras e regularidades que regem as suas existências. No tocante à formulação da memória discursiva de Courtine a respeito do pensamento de Michel Pêcheux (relembrando que inicialmente Courtine foi filiado à $\mathrm{AD}$ pêcheutiana, e que só posteriormente Courtine reclama o postulado foucaultiano para a $\mathrm{AD}$ ), o pai da $\mathrm{AD}$ propõe pensá-la tal qual uma

\begin{abstract}
estruturação de materialidade discursiva complexa, estendida em uma dialética da repetição e da regularização [...] aquilo que, face a um texto que surge como acontecimento a ler, vem restabelecer os "implícitos" (quer dizer, mais tecnicamente, os pré-construídos, elementos citados e relatados, discursos transversos, etc.) de que sua leitura necessita: a condição do legível em relação ao próprio legível (PÊCHEUX, 1999, p. 52).
\end{abstract}

Vê-se de suma importância a condição do legível. Ora, é pelo conceito de memória discursiva que se apreende que a língua deixa de ser puramente estrutural e passa a adquirir historicidade e, consequentemente, produz sentidos. Ao longo desse percurso, ao examinarmos os conceitos foucaultianos até aqui explanados, arrematamos sublinhando que a arqueologia seria um dispositivo teórico-metodológico a serviço da análise de discursos os quais não os abordamos dentro da unidade segura do cogito. Nosso posicionamento, conforme os ensinamentos de Foucault, nos incita, antes, a olharmos para o "conjunto das coisas ditas, buscando as relações, as regularidades e as transformações que podem aí ser observadas, o domínio do qual certas figuras e certos entrecruzamentos indicam o lugar de um sujeito falante" (FOUCAULT, 2010, p. 139).

Diante do conteúdo exposto até então, primeiramente, torna-se importante retomarmos o questionamento foucaultiano: quem fala? (FOUCAULT, 2010, p. 56). Logo, o sujeito que buscamos neste trabalho é aquele cuja constituição é talhada por recortes e fragmentos históricos discursivos, que se agregam, hoje, na dispersão detodas as coisas já-ditas (e vistas) sobre ele. Como observado, para que possamos descrever e analisar um enunciado, em termos arqueológicos, é necessário que averiguemos, munidos dos pressupostos apresentados, as condições sócio históricas de sua emergência, essas determinantes à sua especificidade. Ou seja, àquelas que o produziram de uma determinada maneira, e não de outra. Consequentemente, lançando nosso olhar através de uma lente arqueológica 


\section{Eu, Yayoi Kusama, que pintei minha obliteração, minha obsessão e minhas fobias}

sobre o nosso material de análise, perseguiremos os rastros da memória que possibilitaram acontecer uma persona/corpo Yayoi Kusama "artista-louca", e não outra persona/corpo Yayoi Kusama possível/qualquer.

\section{Premissas genealógicas}

No que se refere à etapa genealógica do postulado foucaultiano, compreende-se fundamentalmente a relação que se estabelece entre os sujeitos, discursos e saberes; logo, sujeitos atravessados por relações de poder. Dessa interligação, sobremodo, pontuaremos em nossas análises (pontuando os conceitos: poder, sujeito, subjetivação, objetivação, relações de poder, microfísica do poder, assujeitamento e dispositivo) a efetivação dos exercícios de poder os quais produzem saberes que nos subjetivam/assujeitam, e que por decorrência nos tornam retalhos discursivos categorizados, normalizados e/ou ainda segregados. Isso quer dizer, para a $\mathrm{AD}$ foucaultiana, que os saberes/poderes são os meios que explicam a "modelagem" do sujeito tal como um objeto a partir de seu próprio conhecimento, ou seja, os modos de sua subjetivação/objetivação.

O sujeito é sempre abordado como um sujeito duplo em razão de ele ser constituído na articulação de dois processos; a sujeição e a subjetivação. Na sujeição, compreende-se aí a figura de um sujeito "idealizado", constituído discursivamente a partir de exterioridades, isto é, o conjunto de coisas ditas sobre ele. Já na subjetivação a concepção de sujeito está mais para o resultado de uma "livre escolha" desse sujeito (figura idealizada) diante da aceitação e/ou rejeição dos discursos nos quais ele jaz atrelado.

Levamos agora a discussão ao conceito de poder que Foucault (2007) esmiúça a partir de contexturas históricas. De início, é necessário destacar que para Foucault o poder tem cunho relacional. Assim sendo, ele não pode ser absoluto nem estar centrado em um lugar. Pelo contrário, segundo Foucault, o poder se distribui numa microfísica das relações; o que significa compreendê-lo em analogia à concepção física da energia, isso na medida em que: i) tanto energia como o poder são entidades que ii) existem em todos os lugares e iii) não podem ser apagados/extinguidos, mas tão somente transformados, todavia. 


\section{Eu, Yayoi Kusama, que pintei minha obliteração, minha obsessão e minhas fobias}

Arrolada a essa analogia, por "microfísica do poder" (2007) entende-se que o prefixo "micro" aí pressupõe a ideia de elementos ínfimos e que entram (cada um conforme suas funções específicas) em relação uns com os outros estabelecendo assim um sistema mais amplo (e consequentemente regrado) de relações onipresentes; ou seja,que ocupam todo tempo e todo espaço possíveis de serem reconhecidas em todos os tipos de relação entre todos os sujeitos. Possível também é pensarmos a analogia do poder com a energia: capacidade de qualquer corpo produzir trabalho, ação ou movimento.

O poder, portanto, não é elemento de posse de uma classe dominante cuja ideologia ilude os dominados. Ao contrário, ele está sempre em movimento cuja existência é vinculada/exercida nas relações entre os sujeitos. Isso implica dizer, de um lado, que o poder não se refere exclusivamente à instituição do Estado ou a outras quaisquer. Inversamente, as instituições são instrumentos do poder, assim, ele não pode ser localizado nelas por se encontrar sempre espraiado na dimensão de nível "micro", logo, ele se dá nas relações cotidianas nas quais não se exclui ninguém. Disso, não se pode concluir que o poder é/seja; sobremodo, ele segue exercido por uns sobre os outros, pois conforme ensina Foucault, ele incorre num

conjunto de ações sobre ações possíveis; ele opera sobre o campo de possibilidade onde se inscreve o comportamento dos sujeitos ativos; ele incita, induz, desvia, facilita ou torna mais difícil, amplia ou limita, torna mais ou menos provável; no limite ele coage ou impede absolutamente, mas é sempre uma maneira de agir sobre um ou vários sujeitos ativos, e o quanto eles agem ou são suscetíveis de agir. [Trata-se de] [u]ma ação sobre ações (FOUCAULT, 1995, p. 243).

Supor que o discurso seja um "produto ideológico" dependeria diretamente de preconizar toda uma sociedade "real" como base empírica de conhecimento, a qual então serviria como parâmetro para a crítica ideológica - suposição comum às análises marxistas. No entanto, rejeitando essa concepção, Foucault, nas palavras de Araújo,

não aceita esse modo de ver, [e] mostra que o marxismo depende de um modelo empírico de conhecimento, o das relações ditas "reais", ouseja, entre as classes, que "explicam", a história como totalidade de movimento [, pois,] o conhecimento da história é a um só tempo conhecimento empírico e transcendental, [ou seja, nesse sentido] o homem condicionado é condição de seu próprio conhecimento (ARAÚJO, 2004, p. 239). 


\section{Eu, Yayoi Kusama, que pintei minha obliteração, minha obsessão e minhas fobias}

Logo, para Foucault, crítico do Marxismo no tocante ao seu modelo das filosofias do sujeito, não há lutas para "derrubar" o poder da classe dominante; lembremos: o poder tem cunho relacional; ele não é possuído. Assim, a luta é de início a resistência aos poderes/saberes. Esse é o cunho relacional referido ao poder em que a "luta" se configura antes num gesto (subjetivo) de denúncia na demonstração de seu funcionamento, em apontar como ele é produzido, disseminado e conduzido pelosdiscursos. Por isso compreende-se que os sujeitos adejam imersos nas relações de poder de maneira ativa, sendo assim, livres para agir (objetivamente) dentro de um campo possíveis comportamentos.

Assim sendo, é a liberdade dos sujeitos que permite o exercício do poder, isso em se considerando que a insubmissão dos sujeitos é o efeito catalisador que provoca o poder. Dito de outro modo, só é possível falarmos sobre as relações de poder onde existam sujeitos livres que podem resistir a esse(s) poder(es) escolhendo como se comportar, reagir, enfim; como se conduzirem a si mesmos diante dele(s). Prontamente, toda relação de poder implica uma relação de resistência, sendo que

não há poder sem resistência, sem escapatória ou fuga, sem inversão eventual; toda relação de poder implica, então pelo menos de modo virtual uma estratégia de luta sem que para tanto venham a se superpor, a perder sua especificidade e finalmente de confundir (FOUCAULT, 1995, p. 248).

Disto isso, da tessitura histórica delineada pelo pensamento genealógico, finalmente, Foucault categoriza os poderes, a saber, como: o poder soberano (semelhante ao poder pastoral), o poder disciplinar e o biopoder. Contornando-os, apreende-se o primeiro deles na relação estipulada entre o rei e o restante da população. Melhor dizendo, entre o corpo "soberano" que é investido de poder absoluto e os corposnos quais, se percebidos possíveis desvios de comportamentos tidos "normais", se incide a interpretação de um ataque direto à autoridade real. Já o poder disciplinar aparece na sociedade industrial capitalista em resposta à sua necessidade de corpos docilizados, domesticáveis às suas demandas. Aí tanto a punição, as “contra-condutas", bem como o valor atribuído ao corpo sofrem um deslocamento conceitual. O corpo para o poder disciplinar segue inserido num sistema de vigilância contínua, a fim de que se obtenha a sua obediência. Assim, substitui-se a punição que antes se configurava na vingança do soberano pela operação do encarceramento do condenado; isso com o objetivo de discipliná-lo, corrigindo o seu comportamento tanto 


\section{Eu, Yayoi Kusama, que pintei minha obliteração, minha obsessão e minhas fobias}

para torná-lo exemplo para criminosos em potencial como para apurar a utilidade desse sujeito em benefício de sua sociedade.

Em seu turno, ao biopoder são conferidos os meios de controlar e regularizar a população, tendo em vista que ele teria surgido de modo a complementar o poder disciplinar. Nesse sentido, uma vez associados, pode-se infligir normatizações num só corpo como em toda uma população que se pretenda regulamentar, asseguradas por "procedimentos de poder que caracterizam as disciplinas [...] anátomo-política do corpo humano" (FOUCAULT, 2017, p. 150). Nessa esteira, as novas tecnologias do poder sofrem, posteriormente, um descolamento do corpo do indivíduo rumo ao corpo- espécie. Isso quer dizer que o corpo é

transpassado pela mecânica do ser vivo e como suporte dos processos biológicos", ou seja, à "proliferação, os nascimentos e a mortalidade,o nível de saúde, a duração da vida, a longevidade, com todas as condições que podem fazê-las variar [, ou seja,] tais processos são assumidos mediante toda uma série de intervenções e controles reguladores: uma biopolítica da população" (FOUCAULT, 2017, p. 150).

O gerenciamento do biopoder (diante da atualidade de nossas relações sociais) se ajusta como tal biopolitica; essa que determina, sob o status de um saber como “medicina social", tudo aquilo o que um grupo de sujeitos deve (ou não) fazer em prol de um bem estar maior para uma dada população. Assim, como resultado do que foi exposto sobre poder, sujeito, subjetivação, objetivação e relações de poder, apreendemos que é inseparável a interligação poder-saber, tendo-se em vista que não existem relações de poder as quais não procedam de um campo específico de saber. Não obstante, os saberes não existem senão inseridos diretamente em relações de poder, e ainda, dessa interligação entendemos que o lugar do sujeito discursivo decorre, portanto, como efeito dessa aliança. Posta assim a discussão, salientamos que

relações de "poder-saber" não devem então ser analisadas a partir de um sujeito do conhecimento que seria ou não livre em relação ao sistema de poder; mas é preciso considerar ao contrário que o sujeito que conhece, os objetos a conhecer e as modalidades de conhecimentosão outros tantos efeitos dessas implicações fundamentais do poder- saber e das suas transformações históricas. Resumindo, não é a atividade do sujeito de conhecimento que produziria um saber, útil ou arredio ao poder, mas o poder-saber, os processos e as lutas que o atravessam e que o constituem, que deter- 


\section{Eu, Yayoi Kusama, que pintei minha obliteração, minha obsessão e minhas fobias}

minam as formas e os campos possíveis do conhecimento (FOUCAULT, 2007, p. 31).

Passemos aos conceitos de assujeitamento e dispositivo. Se, anteriormente, seria possível afirmar que o sujeito resiste contra a própria historicidade que formula o leque de suas atuais identidades, realçamos que esse sujeito que luta/resiste, nesse passo, o fazpelo próprio poder. De qualquer modo, quer as formas de resistência sejam contra ou para o poder, sobretudo elas são efeitos do poder. Isso nos permite tomá-las como uma chave a fim de compreendermos as relações de poder, e, a partir daí, ao localizarmos as posições de onde elas se exercem para, uma vez estabelecidas as relações pelas quais elas se movimentam, enfim possamos mapear os lugares onde são aplicadas (e, conseguintemente, os métodos dessa aplicação) assim entendendo como nós nos assujeitamos, finalmente.

No mais, ligado ao processo de assujeitamento, como se sabe, o conceito de dispositivo foucaultiano é de suma importância. Por dispositivo compreende-se uma categoria analítica da AD. Trata-se de tudo aquilo capaz de mobilizar um determinado saber à nossa disposição, enquanto, consequentemente, os saberes assim são entendidos como elementos do dispositivo. Vale lembrar que, uma vez compreendido que os discursos são postos em circulação via/nas relações de poder-saber, logo os discursos seguem também como elementos do(s) dispositivo(s). Vale ainda ratificar que o status do dispositivo apresenta tudo aquilo (tendo materialidade ou não) cujo funcionamento atinge efeitos desejáveis. Isto é, o dispositivo então

demarca um conjunto decididamente heterogêneo que engloba discursos, instituições, organizações arquitetônicas, decisões regulamentares, leis, medidas administrativas, enunciados científicos, proposições filosóficas, morais filantrópicas. Em suma, o dito e o não dito são elementos do dispositivo. O dispositivo é a rede que se pode tecer entre estes elementos (FOUCAULT, 2007, p. 244).

Em síntese, tais múltiplos e dessemelhantes elementos (materializados ou não) unem-se estrategicamente numa formação, num dado momento específico, como resposta a uma determinada urgência histórica. Esse jogo estratégico dos elementos, portanto, tem como objetivo produzir o efeito de novas subjetividades, essas em correspondência às exigências das novas condições sócio-históricas. Diante a tanto, registra-se ainda que a razão basilar dos dispositivos não corresponde à uma possível repressão ou a uma determinada 


\section{Eu, Yayoi Kusama, que pintei minha obliteração, minha obsessão e minhas fobias}

ideologia. Ela advém, antes, da disciplina e normalização que (em suas especificidades) produz, (re)configura e/ou mantém em função o novo "retrato" da realidade.

Ao buscarmos a arqueologia e a genealogia, pontuamos estarmos diante de duas perspectivas, ambas históricas, as quais se debruçam sobre a linguagem de modo a refutar as histórias continuístas, lineares e causais. Linguagem essa que surge no horizonte de nosso(s) saber(es) e que apega-se ao ser do homem, este que, segundo a AD foucaultiana é

pensado e falado por meio de estruturas, regras, relações designificado e de produções de sentido [numa] sociedade [que], por suavez, tem na ordem discursiva o mais importante veículo condutor e produtor de poder. [Eis, portanto, que] o discurso, para além das relações entre significante e significado, é uma prática, aquela pela qual objetos se formam, na qual sujeitos ocupam o lugar vazio nos enunciados de acordo com normas, direitos, competência técnica prestígio, etc. [E,] além disso, [entende-se que] os enunciados estão sempre cercados por outros enunciados, e sua materialidade, isto é, sua inscrição com efetividade de acontecimento discursivo que toma força, pode ser reativada (ARAÚJO, 2008, p. 192).

Como se sabe, Michel Foucault, sendo herdeiro da escola nietzscheniana, primeiramente, toma para si como objeto de estudo a arqueologia das ciências humanas cujo valor de sua abordagem reside na tentativa de traçar novas configurações no saber, dentre as quais se destaca a abordagem do discurso como prática social em meio a outras práticas; discurso que não se sustenta autonomamente, e que necessita de uma materialidade (verbal/não verbal). Por seguinte, ao abordar a filosofia do sujeito, portanto, Foucault toma emprestado de Nietzsche o conceito de genealogia. Em seu turno, no entanto, cumpre dizer que a genealogia foucaultiana se opõe à pesquisa da origem, da evolução das coisas.

Tem-se inscrito aí o genealogista historiador e não mais o genealogista metafísico, aquele em busca de uma pressuposta essência nas/das coisas. Em outras palavras, para o genealogista historiador as coisas não são mais unidades perfeitas e homogêneas em cuja essência estaria oculta a sua identidade e a sua verdade. Ao contrário, para ele, tudo já está posto de forma constituída pelo trabalho da proveniência, essa considerada a partir de cada peça referente aos elementos diferentes eexteriores da coisa - isto é - pelo conjunto dos acontecimentos históricos - esses, notadamente causais. Por derradeiro, vale ratificar que ao publicar a Microfísica do Poder, em 1979, Foucault propõe o desenvolvimento 


\section{Eu, Yayoi Kusama, que pintei minha obliteração, minha obsessão e minhas fobias}

dessa genealogia que, como se percebe, primeiramente, referia-se a uma genealogia do poder e, num segundo andamento, refere-se à genealogia da ética, momento em que o arquegenealogista verticaliza sua abordagem sobre os modos de subjetivação.

\section{Parrhesia: Pierre Rivière, Yayoi Kusam e a coragem da verdade}

Explicados tanto os pressupostos arqueológicos como genealógicos, neste momento, iniciamos o esboço do "retrato" atualizado da loucura, que propomos analisar. Examinaremos a discursivisação da loucura a partir dos dispositivos a ela arrolados, no tocante à(s) sua(s) forma(s) de expressão/representação no establishment das artes. Consideramo-la, também, a partir de sua formação/rede de ditos e de não ditos aí tecidos conforme um momento específico e como resposta a uma determinada urgência histórica. Para começarmos tal revitalização, aproximamos Yayoi Kusama e Pierre Rivière por meio da apreensão um gesto detectável em ambos.

Ora, o que haveria de comum entre uma artista contemporânea que se proclama louca ao entrar espontaneamente num manicômio e lá decide viver, e um jovem camponês que conhecia eximiamente a constituição romana acerca dos direitos do pai sobre a vida e a morte da esposa, e, contrário às leis de 1835 decide, livremente, matar a mãe, a irmã e o irmão? Não acreditamos que paire sobre esses dois sujeitos apenas a discursivisação da loucura. Parece-nos necessário mais, algo para além da discursivisação da loucura. Logo, constatamos que os dois casos (a auto-internação e o fratricídio) sejam resultados da forja de uma escolha, a demanda interna em resistência apossíveis subjetivações, uma coragem que, para manifestar-se, supõe ao sujeito a instância de um falar - e fazer - francamente: a parrhesia. Passemos a abordá-la.

Encontramos, acerca dos anos 1970 e 1982, resumos publicados por Foucault, por ele redigidos, dos cursos do Collège de France (sendo o último resumo publicado $A$ hermenêutica do sujeito (1982), a exceção dos dois últimos cursos (1983-1984), esses consagrados ao estudo da noção da parrhesia com o seguinte título: A coragem da verdade. É no curso de 1982 que Foucault reconstitui as origens históricas de dois conceitos, fazendo ver como, ao longo da historiografia filosófica, enquanto "o conhecimento de si ganhou 


\section{Eu, Yayoi Kusama, que pintei minha obliteração, minha obsessão e minhas fobias}

peso e privilégio, o cuidado de si foi em geral desconhecido e esquecido" (GROS, 2004, p. 8). No entanto, Foucault aponta que, no nascimento filosófico desses dois conceitos (momento por ele denominado socrático-platônico) mantinham uma relação inversa. Isto é, havia primazia do cuidado de si em precedência ao conhecimento de si.

Grosso modo, nesse curso, Foucault reelabora esses conceitos retomando-os do seguinte modo: ele busca corresponder ao privilégio do conhecimento aquilo que nomeia "filosofia" enquanto, então, denomina "espiritualidade" o cuidado de si. Com essas denominações, podemos dizer que ele reconhece "duas modalidades de conceber e praticar a filosofia, duas vertentes de pensamento, presentes na historiografia filosófica"(GROS, 2004, p. 8). Dessa esquematização, é importante destacar, junto com Frédéric Gros, algumas caracterizações dessas duas vertentes, a fim de que possamos cercear o sujeito pensado pelo filósofo, nesse momento:

na vertente "filosofia" enquanto pensamento exclusivamente representativo, o sujeito, e somente ele, tem acesso à verdade, em razão de sua própria estrutura ontológica, que não é outra senão a de sujeito cognoscente. $\mathrm{Na}$ "espiritualidade" enquanto forma de pensamento e de prática, a verdade não é alcançada nem alcançável pelo sujeito no simples ato de conhecimento, pois, para ter acesso à verdade, o sujeito tem de olhar para si mesmo de modo a modificar-se, converter-se, alterar seu próprio ser (GROS, 2004, p 8-9).

Segundo Gros, na "filosofia", com os "efeitos ou consequências do conhecimento, não há transformação do sujeito", isso, pois, de certo modo, "sua estrutura é que precisa ser assegurada como condição de acesso à verdade" (GROS, 2004, p. 9). Com efeito, a "espiritualidade", contrariamente, "produz efeitos e consequências que incidem sobre o sujeito, iluminando-o e transfigurando-o" (GROS, 2004, p. 9). Se, por um lado, ponderou-se historicamente nas filosofias o âmbito restrito do conhecimento, por outro, Foucault destaca que filósofos da Antiguidade grega (dos períodos helenístico e romano), por sua vez, não dissociavam a questão da filosofia, no que se refere ao "ter acesso à verdade", da questão da espiritualidade, a saber "quais são as transformações necessárias no ser mesmo do sujeito que permitirão o acesso à verdade" (GROS, 2004, p. 9). Isso posto, dessa junção de filosofia e espiritualidade, ou, da verdade e sua prática, é que Foucault designa a noção de $o$ cuidado de si: 
o cuidado de si, assim entendido, remete tão somente ao plano intelecção ou do conhecimento - embora o inclua -, não apenas no âmbito das teorias - embora as justifique -, não somente à ordem da representação - embora a fundamente -, mas também ao plano das atitudes, ao âmbito do olhar, à ordem das práticas, que constituem todo um modo de existência (GROS, 2004, p. 9).

Com esses apontamos, pode-se sugerir, em certa medida, que o curso de 1982 já orientava para o tema da coragem da verdade. Prossigamos. Dos estudos históricos foucaultianos sobre a noção de pahrresia na cultura grega, passando dos trágicos aos cínicos, por filósofos políticos, tal noção, com efeito, escreve Frédéric Gros, "é a liberdade de linguagem, o dar a liberdade de falar, o falar francamente, a coragem da verdade" (GROS, 2004, p. 11). No entanto, Gros considera que seja possível, com esse termo, haver algo mais que uma "nova invenção conceitual, depois da "governamentalidade" e da "subjetivação" (GROS, 2004, p. 11). Tratar-se-ia de algo no sentido de retomar "um ponto entre a articulação e a prática, entre o discurso e as ações, entre os saberes e as resistências" (GROS, 2004, p. 11).

Assim, para Foucault, esse falar francamente, esse nó atado entre a coragem e a verdade constitui-se, portanto, complexamente, no que tange averiguar a coragem da verdade como "grade de leitura da obra e da vida enquanto indissociáveis, enquanto aquilo que, simultaneamente, fundamenta a escrita de livros e a ação política" (GROS, 2004, p. 12), por exemplo. Tem-se, com isso, a proposta desse estudo de Foucault: uma tentativa de decifrar a problemática essencial no que concerne observar que "escrita e ação são uma só e mesma coisa. Não existe um discurso verdadeiro de um lado, neutro, pálido, e, do outro, uma coragem em busca de causas a defender" (GROS, 2004, p. 12).

Ou seja, empreende-se uma arguta tentativa de desdobrar algo (o sujeito) que é, simultaneamente, uma só substância, uma só força, porém, atravessado por várias outras, inúmeras forças que também constituem sua substância existencial. Como diz Gros, a prática de tal estudo atrás dessa noção é como se Foucault se encontrasse na vertical de si mesmo:

Foucault não é filósofo e militante, erudito e resiste. Ele é historiador porque militante, e resistente porque erudito. Para nossos morosos tempos, que organizam a grande divisão entre os doutos isolados na espiral de suas especialidades, tornados inaudíveis pela força do rigore da probidade, e os 


\section{Eu, Yayoi Kusama, que pintei minha obliteração, minha obsessão e minhas fobias}

agentes sociais portadores de discursos ocos e vazios pela força de querer ser ouvidos, é importante lembrar que o saber histórico, com suas exigências próprias, e o engajamento político, com seus riscos, puderam um dia se enriquecer, alimentar-se mutuamente (GROS, 2004, p. 12).

Logo, como exemplo, evidentemente, apreendemos o mesmo impasse para o sujeito Kusama. $\mathrm{O}$ ato transgressor de Kusama, que lhe rendeu visibilidade, mas também segregação e retaliação pelo establishment internacional das artes, favorece e contraria simultaneamente os processos de subjetivação/objetivação da discursivisação da loucura que a delineia. Em sendo "a doença o manancial de sua arte" (LARRATT- SMITH, 2013), Kusama resiste ao establishment por meio de sua loucura, e a mesma loucura the rende um lugar no establishment. Todavia, nossa questão aqui corresponde em como ela, através dessas discursividades e processos subjetivadores, veio, em prática, a ocupar a posição do sujeito histórico "artista-louco".

Para tanto, no que concerne a parrhesia diante da prática de Kusama, ou seja, o ofício do "atista-louco", aprofundemo-nos mais sobre esse conceito. Em linhas gerais, fim de compreender a importância desse conceito, é preciso estabelecer, de início, um jogo de oposições aí fortemente atrelado: "parrhesia e confissão; parrhesia e retórica" (GROS, 2004, p. 156). Contornando o primeiro sistema de oposições, interessado nos estudos da consciência antiga, Foucault empenha-se em mostrar a importância da figura do outro no processo de formação de si. Isto é, "não posso ser chamado a alcançar certa verdade de mim mesmo a não ser por um outro que me exorta e me arranca uma alienação primeira" (GROS, 2004, p. 156). Apreende-se daí tanto a impossibilidade de distinguir, por exemplo, a subjetivação cristã da subjetivação antiga, pois ambas necessitam de uma mesma direção como fundamento de uma prática de si. Contudo, ainda que, nos dois casos exemplificados, o regime de fala é irredutível, nessa primeira oposição confissão/parrhesia, Foucault estabelece um ponto de ruptura entre o si antigo (o si que fala consigo) e o sujeito cristão (o si que demanda o outro, seu diretor de consciência, seu confessor).

O segundo sistema de oposição avançado por Foucault, a parrhesia da retórica, é interno à cultura antiga. Diz respeito de "opor o "dizer verdadeiro" do parresiasta ao "bem dizer" do retórico" (GROS, 2004, p. 157). Enquanto a parrhesia, em sua oposiçãoà confissão, salienta "a fala do mestre autenticada por atos, contra a fala do discípulo capaz de 


\section{Eu, Yayoi Kusama, que pintei minha obliteração, minha obsessão e minhas fobias}

produzir uma identidade pessoal e secreta, a parrhesia, em seu confronto com aretórica, se dá como fala verdadeira, engajada e perigosa" (GROS, 2004, p. 157). Dessa maneira, é que Foucault estabelece tal conceito como uma fala engajada, ou seja, trata- se de supor uma

adesão do falante ao seu enunciado; trata-se de enunciar uma verdade que constitui uma convicção pessoal, ao passo que o problema do retórico não é acreditar, mas fazer acreditar (passagem da convicção à persuasão). Por fim, uma fala perigosa: a parrhesia supõe coragem, porque se trata quase sempre de uma verdade que pode ferir o outro e que assume o risco de uma reação negativa da parte dele, ao passo quea retórica, bem o sabemos, busca bajular o outro, torná-lo dependente de um discurso mentiroso (GROS, 2004, p. 157).

De restante ao conceito abordado, cumpre apenas, neste momento, elucidarmos as quatro grandes modalidades de dizer o verdadeiro. No curso de $1^{\circ}$ de fevereiro de 1984 , Foucault constata haver a existência, na cultura antiga, em sua terceira grande análise diacrítica. São elas:

(i) modalidade profética, pela qual o discurso verdadeiro do oráculo opera uma mediação entre os homens e os deuses, o presente e o futuro, sob uma forma enigmática [...] (ii) modalidade de sabedoria, pela qual o discurso verdadeiro sustentado por um sábio que viva em retiro essencial liberta o ser necessário das coisas do mundo [...] (iii) modalidade técnica, pela qual se trata de transmitir conhecimentos positivos e de assim consolidar uma comunidade de iniciados [...] (iv) modalidade da parrhesia, que se opõe a todas as outras: o parresiasta fala em seu próprio nome e seu discurso refere-se a uma situação atual, singular. Seu lugar natural é a praça pública e ele, por fim, leva a relação com o outro à extrema tensão da ruptura possível (GROS, 2004, p. 157-158).

Brevemente explicitada a parrhesia, esse conceito parece indispensável à composição do "retrato" atualizado do "artista-louco" que pretendemos esboçar a partir da articulação que propomos em nossa análise do embate entre as discursivisações da loucura e Kusama. Desse modo, mais adiante a retomaremos, analisando a noção de coragem de verdade, ou seja, compreendido aqui como o corajoso ato de Kusama ao dizer o verdadeiro (e as causas dessa consequência) que a caracterizaria como um "sujeito parresiasta", isso em consonância à historicidade dos jogos de verdade que cerceiam a fabricação desse sujeito histórico "artista-louco" conforme as regras dos poderes/saberes do establishment/ dispositivo médico. 


\section{Eu, Yayoi Kusama, que pintei minha obliteração, minha obsessão e minhas fobias}

Para prosseguirmos em nosso intuito, também se faz necessário abordarmos, dessa aproximação entre Kusama e Pierre Rivière, a formação/rede de ditos (e não ditos) aí emaranhados num momento específico e como resposta a uma determinada urgência histórica. Dando sequência, ao referirmo-nos à discursivisação da patologia da loucura, seguem algumas rápidas palavras sobre a abordagem foucaultiana a esse respeito.

Ocorre que, no tocante à loucura, em A história da loucura (1961) Foucault traceja arqueologicamente os caminhos da doença evidenciando com isso desde o seu aspecto mais significativo na Idade Média, que é a nau, além de elencar também a relação entre o seu (ou não) tratamento; esse associado ao asilo e ao papel do médico. Grosso modo, o arqueologista dos saberes aqui denuncia as produções de verdade que se apoiavam na prova, no teste e no exame. Disso constata-se, sobretudo, que diante de um saber que o sujeita, o louco não tinha escolha. Ora, para a racionalidade científica, aquele que estivesse do lado da anormalidade não teria "escolha", pois, como percebe Foucault, em sendo o louco sem razão, logo ele não poderia escolher - eis aí o retrato da loucura exibido desde a era da representação: nesse quadro, a razão devia brilhar sozinha.

Tal gesto analítico de Foucault repercute no "movimento da antipsiquiatria" (ARAÚJO, 2008, p. 185), o qual, consequentemente, questiona o que havia de "humanismo" nos hospícios, uma vez que o médico detinha a verdade sobre o louco por meio de "uma instituição a controlá-lo, que faz a própria loucura calar-se e submeter-se aos tratamentos isolados, choques, lobotomias, uso indiscriminado de drogas estupefacientes" (ARAÚJO, 2008, p. 185-186). A partir daí, em sua fase genealógica do poder, a atenção de Foucault e seu grupo GIP (Grupo de Informação sobre as prisões) era regida militantemente em favor dos homens infames. Perscrutando tais vidas paralelas e anônimas conforme essas colidiam com o poder é que surgem as análises sobre a posse/produção da "verdade" da loucura perfilada a partir de batalhas campais relacionadas entre os poderes da psiquiatria e da justiça penal. É desse período que se destaca a obra que trata fundamentalmente da publicação do dossiê do 'caso Rivière' relatado nos Annales d'hygiène publique et de médecine légale, de 1836.

Conforme já o havíamos dito, Foucault resgata o referido memorial dada a sua inquietação com as circunstancias locais do acontecimento, esse que irrompe e é silenciado 


\section{Eu, Yayoi Kusama, que pintei minha obliteração, minha obsessão e minhas fobias}

tão rapidamente como surgiu em sua época. A questão diante desse lampejo histórico para Foucault é simples; retomando-a: "o que havia aí capaz de - após ter chamado tão vivamente a atenção dos médicos - desconcertar o seu saber?" (FOUCAULT, 2003, p. XI). Desautomotizando os discursos psiquiátricos e judiciais entrecruzados no caso Rivière, ou seja, cerceando os sentidos produzidos em ressonância com o acontecimento, Foucault apresenta a autonomia de um "acontecimento exemplar, [em que] o assassino visa aqui, num mundo estático, ao intemporal da opressão e à ordem do poder" (FOUCAULT, 2003, p. 179).

Logo, a percepção de Foucault de tal gesto autônomo, dessa atitude intemporalda opressão perante a ordem do poder; em outras palavras, conduz à reflexão de uma subversão consciente à ordem local e temporal discursivizada (o dossiê Pierre). Nesse sentido, o genealogista das subjetivações traz à luz de nossos dias outra face para o parricida. Por sua vez, o novo retrato de Pierre Rivière requer composição mais sofisticada; tal enquadramento recusa os sujeitos louco e assassino "idealizados", ou seja, constituídos discursivamente a partir de exterioridades referidas ao conjunto de coisas ditas sobre eles (peças judiciárias do processo, as perícias médico-legais realizadas por psiquiatras da época).

É na demão mais profunda dessa pintura que Foucault faz do sujeito Pierre que somos apresentados ao seu novo retrato: eis aí o Pierre - o Pierre fruto do processo de sua subjetivação - isto é, essa executada na concepção de um sujeito como resultado de uma "livre escolha" em resistência às amarras e dimensões de sua figura idealizada. Despe-se assim o louco e o parricida diante da aceitação e/ou rejeição dos discursos nos quais ele jaz atrelado. E quais seriam, nessa medida, os traços perceptíveis dessa sua nova identidade? Foucault a delineia num contraste absolutamente fugaz àquelas percebidas sobre o Pierre figuradas no dossiê. Ele olha para além do jovem de cabeça inclinada e de andar entrecortado, avesso às mulheres, outrora criança perturbada que, por amor ao pai, quis livrá-lo da mulher má que o atormentava nas vias do referido crime. Ora, todas essas coisas que compõem apenas uma paleta de coisas já ditas. Foucault, entretanto, busca por nuances talvez imperceptíveis à época: nesse horizonte pretérito, ele olha para as coisas ainda não ditas. 


\section{Eu, Yayoi Kusama, que pintei minha obliteração, minha obsessão e minhas fobias}

O Pierre de Foucault não é o da lenda do cantão de Aunay. Assim ele destoa de todas as suas discursivizações: a do assassino interrogado por Exupère Legrain em 9 de julho de 1835; do louco bilioso melancólico diagnosticado pelo doutor Bouchard em 21 de julho de 1853; do louco de alienação hereditária diagnosticado pelo doutor L. Vastel em 25 de outubro de 1853; do animal em exibição no tribunal em 4 de agosto de 1835; do culpado condenado à morte que teve a vida poupada pela comutação da clemência real em Calvados a 9 de março de 1836; enfim, daquele que foi encontrado morto na prisão de em 20 de outubro de 1840 a uma e meia da manhã.

O Pierre de Foucault é o infame camponês do século XIX, sujeito cujo "gesto autônomo" reclamou tal acontecimento irrompendo na esteira discursiva desse

campo francês [que] há muito vinha sofrendo o triplo físico do senhor,da Igreja e do rei. [O Pierre de Foucault pertencia aos] camponeses, esgotados como cascas, que o menor vento faz tremer. [É aquele rodeado pela] mortalidade [que] lá estabeleceu seu reino, sustentado pela fome, o frio e as epidemias. A violência negra das sublevações [diante desse, e não outro Pierre Rivière] só teve o efeito regular [nessa formação discursiva] de trazer às arvores, [de irromper-se] paravindimas policiais, cachos de enforcados. [É o sujeito Pierre resultantede uma "livre escolha" em resistência às amarras do camponês idealizado, em resistência às] extorsões de uma parte [bem como,] de outra parte [ao] imediatismo e pesagem de poder. [É o Pierre cujo saberes próprios lhe permitiram crer que, ao seu redor,] tudo é armadilha (FOUCAULT, 2003, p. 189).

Em síntese, o retrato arque-genealógico de Pierre Rivière composto por Foucault configura-se numa tentativa de fazer ouvir a própria "consciência", desse "si" repercurtido através da loucura discursivizada ao redor e pelo próprio camponês cujo "horizonte fechado foi sempre o celeiro destas vidas privadas de qualquer futuro, privadas de qualquer oportunidade" (FOUCAULT, 2003, p. 187), e que, em seu desfecho liberta-se para "o direito de romper o silêncio e enfim falar. De dizer a palavra final, como alguém que volta de longe, e que há muito tempo sabia que a vida deles todos era uma longa coabitação com o inabitável" (FOUCAULT, 2003, p. 187-188).

Como se apreende, a voz desse Pierre retratado por Foucault soa irrefreável a despeito dos discursos jurídico e psiquiátrico. Logo, a abordagem desse dossiê por Foucault e sua equipe promove um profundo estudo das relações que se estabelecem entre a psiquiatria e a justiça penal por mover o acontecimento (o triplo homicídio) em torno do qual 


\section{Eu, Yayoi Kusama, que pintei minha obliteração, minha obsessão e minhas fobias}

"vieram se cruzar discursos de origem, forma, organização e função diferentes" e pelos quais podemos verificar "uma luta singular, um confronto, uma relação de poder, uma batalha de discursos e através de discursos." (FOUCAULT,2003, p. XII).

Exposto esse retrato de Pierre Rivière, e não outro, nós direcionaremos nossa atenção agora para a atualização de um retrato da loucura no establishment das artes contemporâneas a partir da persona discursivizada por/sobre Yayoi Kusama, aquela quediz:

artistas não costumam expressar seus próprios complexos psicológicosdiretamente, mas eu adoto meus complexos e medos como temas. Fico aterrorizada só ao pensar que algo longo e feio como um falo me penetre, e é por este motivo que construo tantos falos Eu construo muitos e muitos deles e então continuo construindo, até que me enterro no processo. A isto dou o nome de "obliteração"19.

A nosso ver, os protagonistas Yayoi Kusama e Pierre Rivière, aparentemente sujeitos em casos distintos e não aproximáveis, unem-se no ponto da loucura auto- proclamada (ambas elas atestadas pelo discurso psiquiátrico) enquanto têm suas subjetividades também reclamadas, ele, pelo discurso jurídico, ela pelo discurso do establishment. Nessa medida, a exemplo do embate discursivo entre médico, juiz e louco pela posse/produção da "verdade" sobre a loucura/monstruosidade, percebemos inserido no establishment das artes um embate similar de poderes/saberes, no caso entre o curador e o artista quanto à posse/produção da "verdade-arte". É diante dessa perspectiva que nós nivelamos as figuras de Pierre e Kusama nesse trabalho como pivôs na evidência de lutas diversas, no tocante aos confrontos e batalhas (re)encontradas nos jogos de discursos e de verdades, e que atuam nesses como armas e instrumentos das relações de poder e de saber. Isso, por considerarmos haver aí perfiladas as críticas às ilusões acerca do sujeito arroladas aos conceitos de materialidade discursiva e de formação discursiva.

Tomado esse exemplo a partir do gesto analítico de Foucault em Eu, Pierre Rivière..., interessa-nos diante da posse/produção da "verdade-arte" no establishment, portanto, a persona Kusama louca que conscientemente demonstra "um esforço pessoal prodigioso combinado com um apetite insaciável de exposição pública” (MORRIS, 2013, p. 56); a persona Kusama cujo corpo - mídia onde incide e reverbera a imagem de sua arte -

19 Declaração de Yayoi Kusama em Yayoi Kusama, Infinity Net: The Autobiography of Yayoi Kusama (2002), trad. Ralph McCarthy. Chicago: The University of Chicago Press, 2011, p. 47. 


\section{Eu, Yayoi Kusama, que pintei minha obliteração, minha obsessão e minhas fobias}

ocupa o lugar do "artista-louco" nesse establishment; a persona Kusama que por meio de seu Kusama World "começou a criar obras públicas memoráveis, adequada para uma nova era de espetáculos" (MORRIS, 2013, p. 56); a persona Kusama que "sempre comprometida com a autopromoção - transformou sua persona extraordinária, assim como seu estilo e "marca" [...] em um produto sedutor para platéias do mundo inteiro" (MORRIS, 2013, p. 59); enfim, a persona Kusama outrora apagada dessa esteira discursiva, mas que irrompe do hospital psiquiátrico Seiwa Hospital for the Mentally novamente para vir ocupar aí a posição sujeito "artista-louco",hoje, artista mulher, mito midiático, mais conhecida como "Suprema Sacerdotisa das Bolinhas" - e não outra.

Por derradeiro, resgatemos nosso intuito de atualizar o retrato da loucura no establishment das artes do século XXI. Ora, se nas palavras de Foucault - filósofo próximo do seio das instituições psiquiátricas e que matou a concepção de homem moderno -, palavras essas escavadas numa arqueologia e forjadas numa genealogia do poder e da ética, o ato de escrever é descrito como transformar-se, desprender-se e dissociar-se de si mesmo, uma vez diante do conjunto de exterioridades ditas e não ditassobre/pela persona de Yayoi Kusama, nós buscaremos decifrar as possibilidades de transformação, de desprendimento e de dissociação desse si próprio em prol (ou não) posição-sujeito "artista-louco" ocupado por Kusama, essa no/em função de retratista da loucura, em seu ofício nas artes. Logo, é condição imprescindível em nosso estudo escandirmos a persona de Kusama em três movimentos analíticos.

Primeiramente propomos uma análise arquegenealógica da produção de sua persona a partir dos conceitos foucaultianos de verdade, jogos de verdade e as técnicas de si. Na sequência, com base na apreensão da Semiologia Histórica - necessária aos estudos que adentram na análise das visualidades - a partir do enunciado verbal "Auto- obliteração de Kusama" (1967), título de um polêmico vídeo obra-prima, passaremos para a produção da persona discursivizada por/sobre Kusama por meio de uma relação intericônica a fim de demonstrá-la, também, (re)construída por meio de uma regularidade enunciativo-imagética, nesse passo, relacionando o referido enunciado verbal a uma controversa obra fotográfica da artista mitificada pela mídia; essa que reverbera diante de possíveis outras margens enunciativas vindas à tona nessa pesquisa através da memória discursiva. 


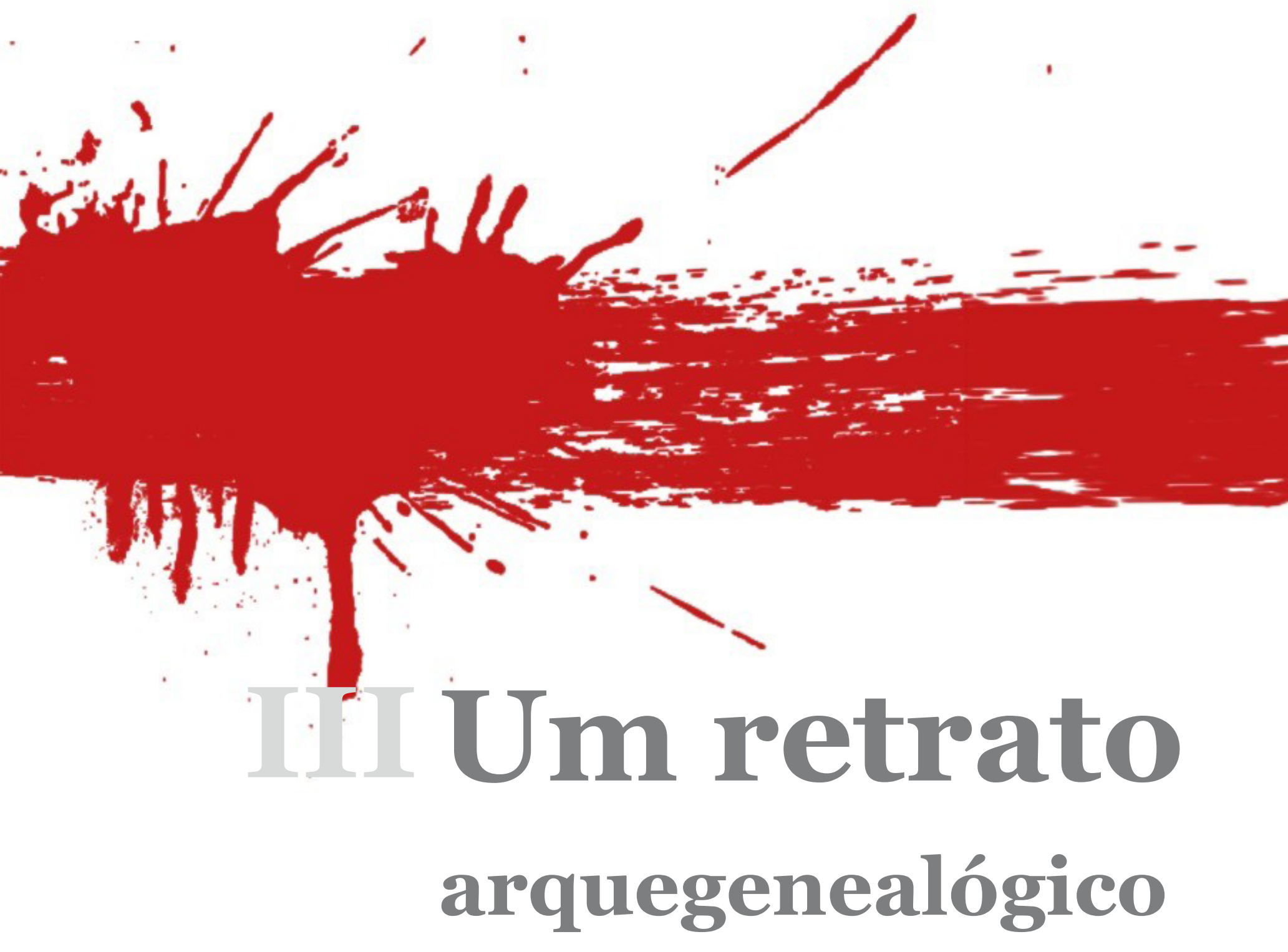


"O si não é reduzivel a uma vestimenta, a uma ferramenta ou a posses. Deve ser procurado no princípio que permite utilizar tais ferramentas, um princípio que não pertence ao corpo, mas à alma. É preciso inquietar-se com a alma - essa é a principal atividade do cuidado de si. Ocuidado de si é o cuidado com a atividade, e não preocupação com a alma enquanto substância. "20

Michel Foucault

Diante da arquegenealogia da vida dos homens infames, Foucault percebe no dossiê Pierre Rivière a autonomia de um acontecimento exemplar, pelo qual um camponês esgotado de seu mundo estático visou libertar-se ao intemporal da opressão e da ordem dos poderes-saberes os quais ele seguia enfrentando/insurgindo. Diante disso, nos termos da liberdade que o camponês encontrou (uma vez autônomo de/em simesmo) na discursivização de sua voz, essa também atravessada pela discursivização de vozes autorizadas por poderes e saberes (assim o assujeitando/subjetivando), a figura de Pierre Rivière se tornou paradoxalmente uma lenda fugaz.

Isto é, enquanto sujeito que ocupou na esteira discursiva psiquiátrica a posição de sujeito louco, Pierre desaparece instantaneamente após sua morte na Prisão Centralde Beaulieu. Já o sujeito que ocupou a posição de assassino na esteira discursiva judiciária, esse reclama a Pierre um lugar à luz entre os monstros mitificados como criaturas historicamente delineadas abjetas.

Perguntamo-nos, então, inspirados pelo gesto analítico de Foucault diante dos sujeitos que, imersos e em resistência em/no embate de poderes e saberes, passaram da infâmia à notoriedade: como a persona/corpo de Yayoi Kusama (outrora mulher e estrangeira excluída da cena pop cultural artística norte-americana) pôde, hoje, coabitar entre os gênios-loucos do inabitável establishment das artes internacionais? Nesse sentido, atribui-se a ela qual gesto autônomo que promovesse um acontecimento aí exemplar? Não o bastante, questionamos: quais relações de poder-saber, como elas se exercem, se aplicam, e o fazem por uso de quais métodos?

20 (FOUCAULT, Michel. As técnicas de si. 1994, p. 22). 


\section{Eu, Yayoi Kusama, que pintei minha obliteração, minha obsessão e minhas fobias}

Inicialmente, destacamos que o cenário que pretendemos escavar aqui em busca do sujeito Yayoi Kusama vai, sobremaneira, ao encontro daquele em que Foucault apresenta os dispositivos de poder e as práticas de si. Em A vontade de saber (2017), primeiro volume da História da sexualidade, em "Método", Foucault tece suas formulações sobre o poder anunciando uma nova problemática em torno da sexualidade,desse modo se distanciando dos grandes quadros históricos abordados em História da loucura e Vigiar e punir. Em outras palavras, em sua fase genealógica surge um novo cenário cultural não mais centrado no Ocidente do século XVI ao século XIX; trata-se de uma "leitura ética em termos de práticas de si que desloca a leitura política dos dispositivos do poder. A problemática do sujeito ocupa agora o primeiro plano" (BARROS, 2006, p. LVIII).

Dessa maneira, a partir de sua abordagem da hermenêutica do sujeito, no que diz respeito aos textos Governo de si e dos outros e Religião, no estabelecimento de seu texto, Foucault, observando o Estado na década de 1970, traça uma genealogia para as nossas sociedades modernas. Logo, o Estado para Foucault se apresenta em duas faces, simultaneamente compreendidas como "totalizante e individualizante" (BARROS, 2006, p. LIX). Ou seja, o Estado moderno, de composição estrutural dupla, apresenta de um lado a governamentalidade pastoral (de tradição judaico-cristã, nesse ponto distante do mundo grego), e do outro as estruturas da razão de Estado (a instituição que enquadra as populações e que identifica os indivíduos). Fundamental para o nosso trabalho, dessa encruzilhada de duplo controle simultaneamente individualizante na qualo sujeito se destaca, vale destacarmos, portanto, o conceito de governamentalidade, que para Foucault se refere, primeiramente, ao

conjunto constituído pelas instituições, procedimentos, análises e reflexões, cálculos e táticas que permitem exercer essa forma bem específica, bem complexa, de poder, que tem como alvo principal a população, como forma mais importante de saber, a economia política, como instrumento técnico essencial, os dispositivos de segurança. [Em segundo, trata-se da] tendência, a linha de força que, em todo o Ocidente, não cessou de conduzir, e há muitíssimo tempo, em direção à preeminência desse tipo de saber que se pode chamar de "governo" sobre todos os outros: soberania, disciplina. [Por fim, por governamentalidade pode-se entender] o processo, ou melhor, o resultado do processo pelo qual o Estado de Justiça da Idade Média, torna-se nos séculos XV e XVI Estado administrativo, encontrou-se, pouco a pouco, "governamentalizado". (FOUCAULT, 2006, p. 303.) 


\section{Eu, Yayoi Kusama, que pintei minha obliteração, minha obsessão e minhas fobias}

Em síntese, ao abordar o sujeito pelo conceito da governamentalidade, Foucault não o relaciona especificamente no que diz respeito ao estudo das regras, dos deveres, das proibições e das restrições associadas ao dispositivo da sexualidade. No governo de si, Foucault se desvia dos atos que eram permitidos e proibidos ao sujeito para se deter nos atos pelos quais figuram a condução as condutas, quer sejam individuais (governode si) ou coletivas (governo dos outros). Considerava que nas "condutas do si que estavam representados, os pensamentos e os desejos que podiam ser suscitados, a inclinação a perscrutar no si todo sentimento escondido, todo movimento da alma, todo desejo travestido sob formas ilusórias" (FOUCAULT, 1994, p.16). Dito de outro modo, nesse movimento de sua fase genealógica, Foucault, salientando na figura do sujeito tais rastros de desejos, esses configurados em diversas formas, assim acena para a existênciade "uma sensível diferença entre as proibições concernentes à sexualidade e as outras formas de proibição" (FOUCAULT, 1994, p. 16).

Ciente que as proibições sexuais também estão ligadas à obrigação de dizer a verdade sobre o si, Foucault (por sua vez distante da abordagem que apreende a evolução do comportamento sexual) propõe uma reflexão sobre o comportamento histórico do sujeito, isso no que diz respeito ao laço estabelecido entre a sua obrigação de dizer a verdade e as proibições que pesam sobre a sua sexualidade. E, para tanto, é crucial para Foucault saber "por qual decodificação de si mesmo o sujeito constrangeu-se, naquilo que concerne ao que [lhe] foi proibido" (FOUCAULT, 1994, p. 16).

Com isso, em se partindo de uma questão que interroga a relação entre ascetismos e verdades, esses em seus respectivos turnos dispostos por meio desse Estado Moderno de estrutura dupla (a governamentalidade pastoral e as estruturas de razão do Estado), o que se objetiva com a governamentalidade do si diante desses poderes-sabres totalizantes e individualizantes é delinear a figura desse sujeito. Assim, sua constituição liga-se de maneira singular e complexa, simultaneamente, de um lado à proibição verbal e à obrigação de dizer a verdade, e de outro, às práticas que escondem aquilo que faz ao passo em que busca decifrar quem se é.

Temos aí, portanto, um jogo que envolve o sujeito na manobra de poderes e saberes diante de tradições pastorais e instituições que, por fim, enquadra desde as populações ao 
mesmo passo em que identifica os seus indivíduos. Logo, conforme ensina Foucault, prosseguindo com a decodificação do sujeito Yayoi Kusama, necessário é aproximá-lo, primeiramente, à esteira analítica das "técnicas de si" e dos "jogos de verdade", conforme o faremos a seguir.

\section{Artistas, monstros, jogos e práticas infames}

"Tinha lido a história romana, e tinha visto que as leis dos romanos davam ao marido direito de vida e morte sobre sua mulher e seus filhos. Quis desafiar as leis, pareceu-me que seria uma glória para mim, que me imortalizaria morrendo por meu pai [...] e eu morreria para libertar um homem que me ama, e que me quer bem. [...] Todas essas coisas me passavam pelo espírito, eme levaram a agir. [...] Eu também me sacrificarei por meu pai; tudo parecia me convidar a este ato." ${ }^{21}$

Pierre Rivière

"Sinto como se estivesse em um lugar em que cortinas listradas pregueadas me envolvem completamente e, finalmente, minha alma se separa do corpo. Assim que isto ocorre, posso colher uma flor no jardim, por exemplo, semser capaz de senti-la. Caminhando, sinto como se estivesse nas nuvens; não sinto meu corpo como algo real." 22

Yayoi Kusama

Quem fala? Do passado, escavamos as palavras do camponês que assassinou a mãe grávida, sua irmã Victoire e seu irmão caçula Jules, as quais alegam, conforme o autor do fratricídio, possuir o espírito atravessado em/na sua loucura que o levou a cometer tal ato. Do presente, salientamos a declaração de Yayoi Kusama que em/na sua loucura explica o exorcismo de sua alma extraviada do próprio corpo, esse cuja configuração então se dá atravessada por cores, listras, flores e nuvens. Mediante essas falas, gostaríamos de salien- 


\section{Eu, Yayoi Kusama, que pintei minha obliteração, minha obsessão e minhas fobias}

tar o elemento em comum que surge em ambos os relatos: um exercício da/para a loucura; prática aí percebida em dois sujeitos, duas personas/corpos, os quais falam a partir de/ em posse/produção sobre as verdades da loucura (àquela do assassino-louco, àquela da artista-louca).

Retornando à figura do sujeito, a análise do discurso foucaultiana estabelece os conceitos de crítica às ilusões deste ao arrolá-lo aos conceitos de materialidade discursiva e de formação discursiva. Nesse contexto, se tendo em vista que a língua é para Foucault função de regras, o sujeito não é sobremodo considerado cego, iludido como resultado ou produto de um discurso. O sentido que se estabelece para o sujeito, desse modo, é sua $o c u$ pação numa posição cuja existência pode vir a ser tomada por determinados indivíduos. Assim sendo, compreendemos Pierre e Kusama como sujeitos cujas práticas, cada um ao seu tempo, buscam o estabelecimento da ocupação da posição discursiva "sujeito-louco", respectivamente cada qual em suas dadas esteiras discursivas. Ele na esteira Jurídica, ela no Establishment das artes. Ambos aproximados pela esteira da Psiquiatria, no entanto.

Como se sabe, tal abordagem é possível na AD foucaultiana por considerar o sujeito de um discurso (como o artista que se institui no discurso artístico, por exemplo) ser sempre individualizado por práticas disciplinares, objetivado por práticas epistêmicas e, ainda, ser também subjetivado por práticas das ciências confeccionais. Logo, percebemos em Foucault um posicionamento teórico incisivamente contrário à ideia de que se faça, previamente, uma teoria a priori do sujeito supondo possível a existência de uma dada essência humana, então mascarada, alienada ou condicionada por mecanismos de repressão, pressupostos por processos linearmente históricos, econômicos e/ou sociais. Diante disso, na $\mathrm{AD}$ foucaultiana, ao sujeito é atribuída a prática da resistência.

Embora sejam reconhecíveis e pertinentes as inúmeras dimensões referidas à figura do sujeito enquanto objeto de análise (sujeito gramatical, sujeito intencional, sujeito psicológico, sujeito das formulações, dos atos de fala, sujeito da relação falante- ouvinte) essas dimensões desse sujeito em resistência, no entanto, não podem ser sobrepostas. Isso porque, para a $\mathrm{AD}$ foucaultiana, delineia-se o sujeito posicionando-o numa possibilidade de produção pessoal histórica, intrinsecamente atravessada pela história (uma vez que o 


\section{Eu, Yayoi Kusama, que pintei minha obliteração, minha obsessão e minhas fobias}

homem condicionado é condição de seu próprio conhecimento), assim como também já o pontuamos anteriormente.

Tendo até aqui retomado os aspectos fundamentais sobre a crítica das ilusões do sujeito, partamos agora para outra perspectiva do postulado foucaultiano disponível aos estudo da Análise do Discurso; àquela que atribui ao sujeito determinadas possibilidades de gestos autônomos, esses subjetivos/subjetivadores, os quais Foucault chama "técnicas de si" e que seguem associados a determinadas redes estratégicas, os "jogos de verdade". Em A escrita de si (1988), texto publicado primeiramente em 1982, Foucault estabelece uma reflexão sobre o(s) modo(s) de se constituir o 'si' a partir dos complexos campos que se atrelam à hermenêutica das técnicas de/do si nas práticas pagã e cristã dos primeiros tempos, bem como à teologia da alma. Com essa reflexão,Foucault buscava isolar ou distinguir a constituição de nossas experiências espontâneas.

Logo, nesse texto Foucault trata especificamente dos modos de subjetivação, ou seja, as práticas de constituição do sujeito, intituladas "práticas de si", "técnicas de si" e "cuidado de si”. Escandindo tais conceitos, Foucault estatui que práticas como a racionalidade ou a regularidade por fim organizam as ações dos homens num caráter recorrente e sistemático arrolado à ética, aos poderes e aos saberes. É no contexto dessa reflexão que Foucault divide essas práticas/modos de subjetivação em quatro grandes grupos, chamados respectivamente de "1) as técnicas de produção", "2) as técnicas de sistemas de signos", "3) as técnicas de poder", e "4) as técnicas de si." (FOUCAULT, 1994, p. 17). Para o arquegenealogista, estas se dividem em grupos onde cada qual representa, por conseguinte, uma matriz da razão prática. Ou seja, pelo intermédio das técnicas de produção, pode-se

produzir, transformar e manipular objetos [,enquanto as] [...] técnicas de sistemas de signos [...] permitem a utilização de signos, de sentidos, de símbolos ou de significação; [já] [...] as técnicas de poder [...] determinam a conduta dos indivíduos, submetendo-os a certos finsou à dominação, objetivando o sujeito; [e, por fim,] [...] as técnicas de si, [...] permitem aos indivíduos efetuarem, sozinhos ou com a ajudade outros, um certo número de operações sobre seus corpos e suas almas, seus pensamentos, suas condutas, seus modos de ser; de transformarem-se a fim de atender um certo estado de felicidade, de pureza, de sabedoria, de perfeição ou de imortalidade (FOUCAULT, 1994, p. 17). 


\section{Eu, Yayoi Kusama, que pintei minha obliteração, minha obsessão e minhas fobias}

Vale notar que, quanto à prática desses quatro tipos de técnicas, Foucault adverte que todas funcionam numa interação constante, já que cada tipo segue associada a uma determinada forma de dominação. Dessa maneira, compreende-se que "cada um dos tipos implica em certos modos de educação e de transformação dos indivíduos, na medida em que se trata não somente, evidentemente, de adquirir certas aptidões, mas também de adquirir certas atitudes" (FOUCAULT, 1994, p. 17).

Em linhas gerais, Foucault pontua que as duas primeiras técnicas (as técnicas de produção e as técnicas de sistemas de signos) dirigem-se, comumente, ao estudo das ciências e da Linguística. As demais (técnicas de poder/dominação e técnicas de si) foram as quais Foucault mais se ateve em sua análise, sobremaneira no que concerneaos seus estudos sobre a loucura cujo intuito era "mostrar qual tipo de gestão dos indivíduos no interior e no exterior dos manicômios esse estranho discurso tornoupossível" (FOUCAULT, 1994, p. 17). Assim, o domínio das técnicas de dominação exercidas sobre os outros e das técnicas de si é aquilo que Foucault compreende como exercício de governamentalidade.

Sobre o exercício da governamentalidade, esse se dá a partir de dois contextos distintos teóricos que Foucault esboça a evolução da hermenêutica para as técnicas de subjetivação, mais precisamente: a filosofia greco-romana dos dois primeiros séculos doinício do Império Romano e a espiritualidade cristã junto ao seu ideário monástico em desenvoltura nos IV e V séculos, sob o Baixo-Império (ou seja, a dupla estrutura do Estado moderno). Contudo, Foucault investiga também na Antiguidade tardia uma abordagem para o sujeito que almeja escandir. Desse período, evoca em sua empreitada um conjunto de práticas tomadas como "a forma de um preceito: epimeleisthaisautou, isto é, "tomar conta de si”, ter “cuidado consigo", "preocupar-se, cuidar-se de si”" (FOUCAULT, 1994, p. 18).

Escavando os três preceitos acenados, Foucault os analisa a partir de distintos momentos históricos. Percebe, no entanto, que eles não seguem isolados temporalmente. Ao contrário, eles decorrem historicamente contiguamente atrelados. Em linhas gerais, para os gregos, o "cuidado de si" fundamentava a arte de viver configurando "as regras de conduta da vida social e pessoal" (FOUCAULT, 1994, p. 18). Trata-se de uma noção um tanto obscurecida na contemporaneidade, em razão de o princípio moral délfico gnôthiseauton, 


\section{Eu, Yayoi Kusama, que pintei minha obliteração, minha obsessão e minhas fobias}

o "conhece-te a ti mesmo" (FOUCAULT, 1994, p. 18) ter-se sobreposto ao princípio moral dominante da filosofia na Antiguidade, o "tome conta de você mesmo" (FOUCAULT, 1994, p. 18). Colocando a proposição acenada de outro modo, existem várias razões para explicar como o "conhece-te a ti mesmo" eclipsou o "cuida de ti mesmo". Para Foucault, a primeira delas refere-se à profunda transformação sofrida pelos princípios morais passados pela sociedade ocidental. Em suas palavras,

experimentamos a dificuldade de fundamentar uma moral rigorosa e princípios austeros sobre um preceito que mostra que devemos nos preocupar conosco mesmos mais do que qualquer outra coisa. Inclinamo-nos, em princípio, a considerar o cuidado de si como qualquer coisa de imoral, como um meio de escapar a todas as regras possíveis. Herdamos isso da moral cristã, que faz da renúncia de si a condição da salvação. Paradoxalmente, conhecer-se a si mesmo constituiu um meio de renunciar a si mesmo. (FOUCAULT, 1994, p. 19).

Conforme visto acima, tem-se salientada a herança da moral cristã herdada a partir de uma tradição secular ocidental. Consequentemente, Foucault então compreende nisso uma moral social que age como estopim da fundamentação das regras de comportamento admissíveis sobre as relações com os outros. Nessa perspectiva, tendo tal moral se estabelecendo (depois do século XVI) como objeto de uma crítica, isso se dá

em nome da importância do reconhecimento e do conhecimento de si"; logo, o "Conhece-te a ti mesmo" eclipsou o "cuida de ti mesmo", porque nossa moral, uma moral do ascetismo, não parou de dizer que o si é a instância que se pode rejeitar (FOUCAULT, 1994, p. 20).

A segunda razão proposta por Foucault para tal obscurecimento refere-se ao conhecimento de si - o sujeito pensante (atrelado à filosofia teórica de Descartes a Husserl) - uma vez que este recebe "uma importância tanto maior enquanto ponto de referência da teoria do conhecimento." (FOUCAULT, 1994, p. 20). No sentido que se coloca, nesse passo para Foucault ocorre uma

inversão na hierarquia dos dois princípios da Antigüidade, "cuida de timesmo" e "conhece-te a ti mesmo". Na cultura greco-romana, o conhecimento de si aparece como conseqüência do cuidado de si. No mundo moderno, o conhecimento de si constitui o princípio fundamental (FOUCAULT, 1994, p. 20). 


\section{Eu, Yayoi Kusama, que pintei minha obliteração, minha obsessão e minhas fobias}

Em decorrência dessa concepção que evoluiu por toda a antiguidade como uma história do cuidado de si mesmo, essa se compõe de modo a fazer a história da subjetividade através das formações e transformações das relações consigo mesmo que ocorrem culturalmente, ou seja: através das práticas e das técnicas de si (ritos depurificação, técnicas de concentração da alma, técnicas de retiro, por exemplo). Não obstante, Foucault busca pelo diálogo entre a cultura e as práticas de si no Alcibíades I de Platão (texto s/d), em cujo centro se estabelecem apreços pessoais na forma de uma noção grega chamada epimeleisthaisautou - o cuidado que se toma consigo mesmo.

Em suas palavras, esta expressão implica

sempre uma atividade real e não simplesmente uma atitude. A expressão se aplica à atividade do fazendeiro, que se ocupa de seus campos, vela por sua tropa e cuida de sua fazenda; ao trabalho do rei, que vela pela cidade e por seus súditos; ao culto dos ancestrais e dos deuses; em medicina, a expressão remete aos cuidados que se tem comas doenças. Significativo, o cuidado de si [...] está diretamente ligadoà idéia de uma pedagogia defeituosa - uma pedagogia que concerne à ambição política e um momento particular da vida (FOUCAULT,1994, p. 21).

Enfim, o epimeleisthaisaltou - o cuidado de si - é associado a um estado político que expressa coisas, relações; ações mais sérias do que superficialmente sugerem aparentar, e que, ainda, é estabelecido por práticas racionais e regulares. Dessa forma, no cuidado de si se observa a organização das ações dos homens num caráter recorrente e sistemático arrolado à ética, aos poderes e aos saberes. Como se depreende, as técnicas de si constituem uma experiência referida ao caráter reflexivo e de auto-análise que as permeiam. Ou seja, para o sujeito as técnicas de si estão como as táticas, estratégias. Tratam-se de movimentos de um "jogo estratégico" onde a liberdade do sujeito é evidenciada. As "práticas de si" e as "técnicas de si" implicam, deste modo, uma reflexão sobre um determinado modo de vida, sobre uma determinada maneira de regular a própria conduta, por fim, um gesto particular de fixar para si a posição-sujeito que assume.

Uma vez apresentada a constituição das “técnicas de si”, voltemos aos sujeitos eleitos pivôs para o desenvolvimento da análise desse trabalho. Como dissemos, nesse movimento de sua fase genealógica, Foucault relata seu interesse não apenas sobre as regras, os deveres, as proibições e as restrições associadas à sexualidade no tocante aos atos que nesta eram permitidos ou proibidos, mas também avalia a representação de sentimentos 


\section{Eu, Yayoi Kusama, que pintei minha obliteração, minha obsessão e minhas fobias}

que tangem tais territórios em decorrência de um "desejo travestido sob formas ilusórias" (FOUCAULT, 1994, p. 16).

Assim, cerceando o laço que se estabelece entre a obrigação de dizer a verdade e as proibições que pesam sobre a sexualidade, Foucault projeta evidências sobre as quais pairam a decodificação do si mesmo quanto à figura do sujeito. Notando haver um constrangimento por parte do sujeito quanto àquilo que lhe teria sido proibido, diante detais inquietações e interdições, essas ligadas ao pensamento de $\operatorname{Max}_{W^{2}}{ }^{23}$ (1864- 1920), no qual o desejo da adoção de um comportamento racional e regulador na açãodo sujeito se exerce ao custo de uma parcela de si, Foucault então apreende conseguintemente da esteira de Weber para sua análise o ato de sujeição.

Segundo Weber, o sujeito deve, ao suprimir uma parte sua em obrigação a dizer a verdade, inevitavelmente renunciar-se e esconder-se de si, das coisas que faz e de quem se é. Destacado tal gesto, Foucault subverte o processo de configuração desse si pensado por Weber formulando assim a sua abordagem: "como certos tipos de saberes sobre o si são advindos do preço a pagar por causa de determinadas formas de proibição? O que se deve conhecer de si a fim de aceitar a renúncia?” (FOUCAULT, 1994, p. 16). Tal abordagem nos direciona inevitavelmente para o gesto analítico de Foucault diante da vida dos homens infames.

Conforme explanamos, junto ao embate dos poderes-saberes psiquiátricos ejudiciários em voga na época, chama atenção no dossiê Pierre Rivière também à parcela dos saberes pessoais de Pierre, esta em colisão contra esses poderes-saberes. Ou seja, apreendendo-se o conhecimento pessoal e Pierre sobre as leis dos romanos, os quais colidiam diretamente com as leis judiciárias de seu tempo (uma vez que eles interditavam ao cônjuge o direito de vida e morte de sua esposa e filhos), apreende-se nessa medida uma parcela de Pierre em prática de uma técnica de si.

Como resultado desse embate, reatando agora o jogo em que Foucault estatui haver o exercício da "governamentalidade" e "as técnicas de si", observamos que ao afrontar a lei por cometer o fratricídio, Pierre Rivière mostrou-se disposto a renunciar uma parcela de si (aquela referente ao filho de agricultores, camponês, livre) quando,em conheci-

23 Karl Emil Maximilian Weber foi um intelectual, jurista e economista alemão considerado um dos fundadores da Sociologia cujos principais trabalhos são Economia e Sociedade (1956, obra póstuma) e $A$ ética protestante e o espírito do capitalismo (1904). 


\section{Eu, Yayoi Kusama, que pintei minha obliteração, minha obsessão e minhas fobias}

mento das referidas leis romanas, assume outra parcela de si (aquela referente à figura imortalizada, o assassino, lenda de Caen) e que paga, conscientemente, o preço da morte cobrado pelos poderes judiciários de seu tempo. Preço pago pelo dizer o verdadeiro? À luz da noção de parrhesia, certamente sim. Tendo dito isso, consideramos que, a exemplo da observação do exercício da "governamentalidade" e de "as técnicas de si" no sujeito Pierre, é admissível verificar o mesmo exercício no sujeito Kusama. Vejamos como isso se dá.

Como se depreende, é inevitável notarmos a força de poderes-saberes fragmentando o sujeito Kusama em duas partes. De um lado, observamos a parcela de sido sujeito Kusama (àquela da renomada artista-louca que vive internada, por vontade própria, num instituto psiquiátrico). Parcela essa no caso advinda de um preço pago por causa das formas de interdição sofridas no establishment (artista excluída desse cenário, que volta ao Japão). Não obstante, do outro, encontramos a outra parcela de si do sujeitoKusama renunciada em prol da primeira (àquela da artista, mulher estrangeira que outrora buscou sem sucesso um lugar no cenário pop das artes em ebulição na América).

E o quê apreendemos disso? Eis aí o jogo das vidas infames: percebe-se nele a ebulição de desejos de sujeitos comuns que, ao tomarem para si formas ilusórias a partir de um gesto autônomo (brandido graças a um conhecimento sobre o si) conduz o sujeito da infâmia à notoriedade, leva-o - travestido de uma nova parcela de si - para além das margens subjetivas/subjetivadoras que antes assim, por determinados poderes-saberes o assujeitava.

Em outras palavras, observa-se, junto com Foucault, a existência de modos de subjetivação, ou seja, de práticas que possibilitam e asseveram a constituição do sujeito,sujeitos tais como Pierre e Kusama. Assim sendo, essas práticas se referem às formas deatividade sobre o si mesmo (as técnicas de si) elucidadas, como visto, a partir dos conceitos de "práticas de si", "técnicas de si" e "cuidado de si", por sua vez extraídos da antiguidade grega a fim de que se estabeleça uma forma pela qual o sujeito se constitui. Desse modo, assim como ensina Foucault, estamos diante de uma produção histórica pessoa

das diferentes maneiras nas quais os homens, em nossa cultura, elaboram um saber sobre eles mesmos [tais como:] a economia, a biologia, a psiquiatria, a medicina e a criminologia. [Logo,] [o] essencial não é tomar esse saber e nele acreditar piamente, mas analisar essas pretensas ciências como outros tantos "jogos de verdade", que são colocadas como técnicas específicas dos quais os homens se utilizam para compreenderem aquilo que são. (FOUCAULT, 1994, p. 17) 


\section{Eu, Yayoi Kusama, que pintei minha obliteração, minha obsessão e minhas fobias}

Conseguintemente, o sujeito pensado por Foucault é aquele constituído porconjuntos de regras de produções da verdade (os procedimentos/saberes como artes, psiquiatria, medicina, criminologia etc.) e também pelas mudanças das regras que produzem tal/tais verdade(s), uma vez que esta(s) se mostra(m) instituída(s) ou destituída(s) pelos próprios sujeitos, através de práticas por eles próprios produzidas e compreendidas históricamente. Ora, o que queremos dizer é que em resistência aos poderes-saberes que os subjetivavam/objetivavam, o sujeito Pierre (o assassino) executou o fratricídio a partir dos próprios saberes de si, tal qual o sujeito Kusama artista-louca ganhou notoriedade a partir da afirmação (e reconhecimento) do seu saber de si (a loucura). Isso porque o sujeito, em Foucault, é constituído pelos referidos "jogos de verdade" nos quais ele se encontra assujeitado e, simultaneamente (em razão de certa margem de liberdade que possui) pode romper com tal assujeitamento - dado o exercício das práticas de si e seus modos de subjetivação.

De resto, cumpre ainda salientarmos que, para Foucault, o sujeito tão pouco é compreendido como uma substância. Ele se aproxima mais a uma forma que, entretanto,não é idêntica a si mesma. Como já mencionado, as dimensões do sujeito não se sobrepõem; o sujeito político não tem consigo próprio o mesmo tipo de relação enquanto sujeito de uma sexualidade, por exemplo. Isto é, para cada relação estabelecida, o sujeito proposto por Foucault se posicionará de uma forma diferente, porisso mesmo, surgem inúmeras formas de sujeito de acordo com as relações que este vema estabelecer com os diversos "jogos de verdade" aos quais se atrela.

Em resolução às reflexões que trazemos nesse seguimento, por fim observamos que a abordagem do sujeito por Foucault abarca uma história dos diferentes modos pelos quais, então, os seres humanos tornaram-se sujeitos. Isso tudo posto, passamos agora para a análise da construção do sujeito Kusama segundo o establishment das artes contemporâneas. Vejamos adiante como, nessa arena cujos poderes-saberes detêm a(s) "verdade(s)" sobre a arte, o sujeito Kusama - composição aos moldes foucaultianos (logo, esse em resistência a tais poderes-saberes por usufruir do exercício da "governamentalidade" e das "técnicas de si") elabora, consequentemente, uma forma que se ajusta à posição "artista-louco", forma que aí reside tão somente autorizada. 


\section{O Kusama-Word: a loucura em exposição}

"O espetáculo (da sociedade de consumo) que é a extinção dos limites do eu e do mundo pelo esmagamento do eu que a presença-ausência do mundo assedia, é igualmente a supressão dos limites do verdadeiro e do falso pelo recalcamento de toda a verdade vivida sob a presença real da falsidade que a organização da aparência segura. Aquele que sofre passivamente a sua sorte quotidianamente estranha é, pois, levado a uma loucura que reage ilusoriamente a essa sorte, ao recorrer a técnicas mágicas." ${ }^{24}$

Guy Debord

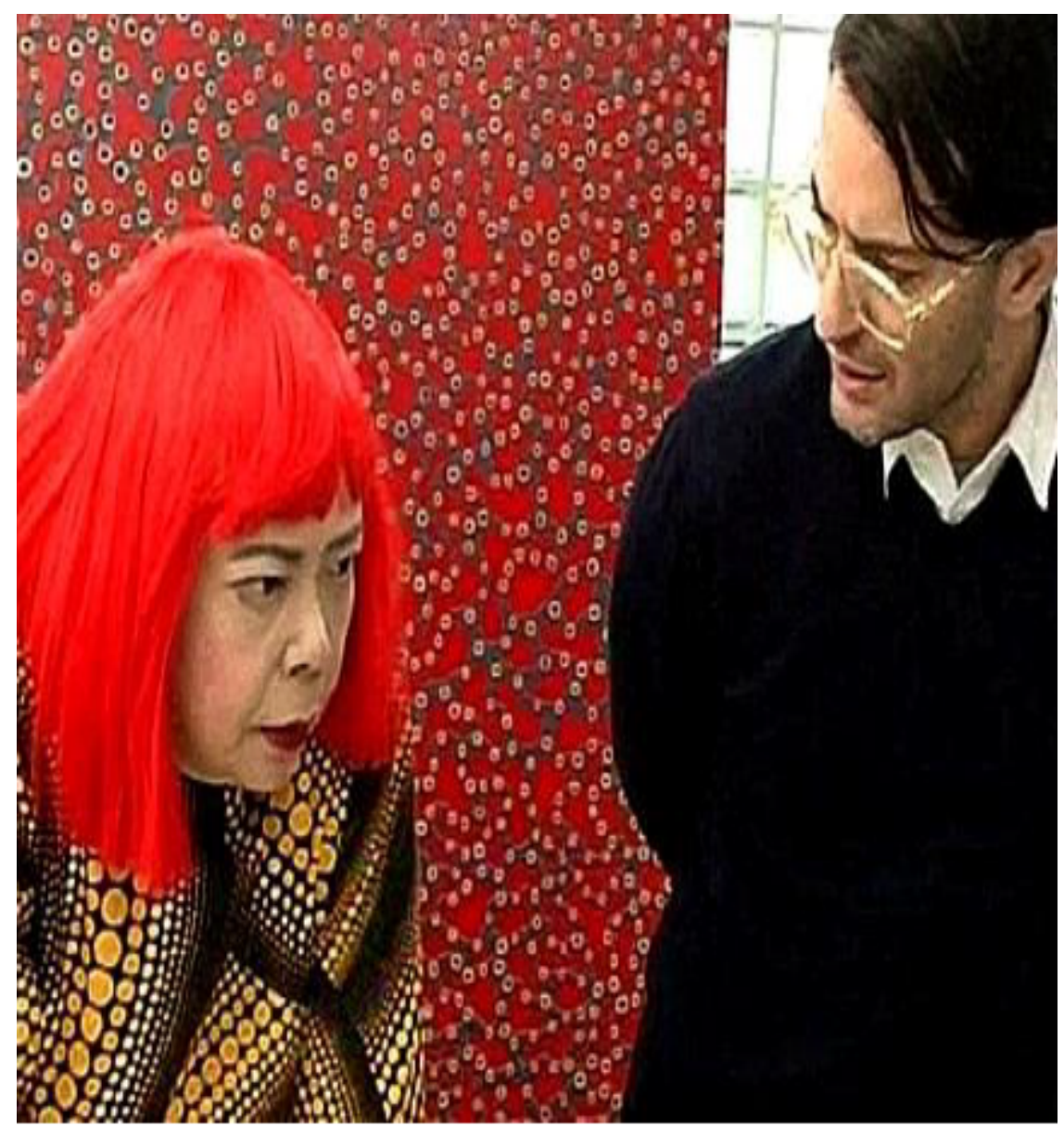

Figura 3 - Kusama e Marc Jacbs 1.

Fonte: Photo (C) Gautier Deblonde, 2012. Disponível em: <http://fadmagazine.com/2012/01/10/marc -jacobs - recruits -yayoi-kusama -for-art-installation - collaboration/ > Acesso 12 junho 2017.

24 Karl Emil Maximilian Weber foi um intelectual, jurista e economista alemão considerado um dos fundadores da Sociologia cujos principais trabalhos são Economia e Sociedade (1956, obra póstuma) e $A$ ética protestante e o espírito do capitalismo (1904). 


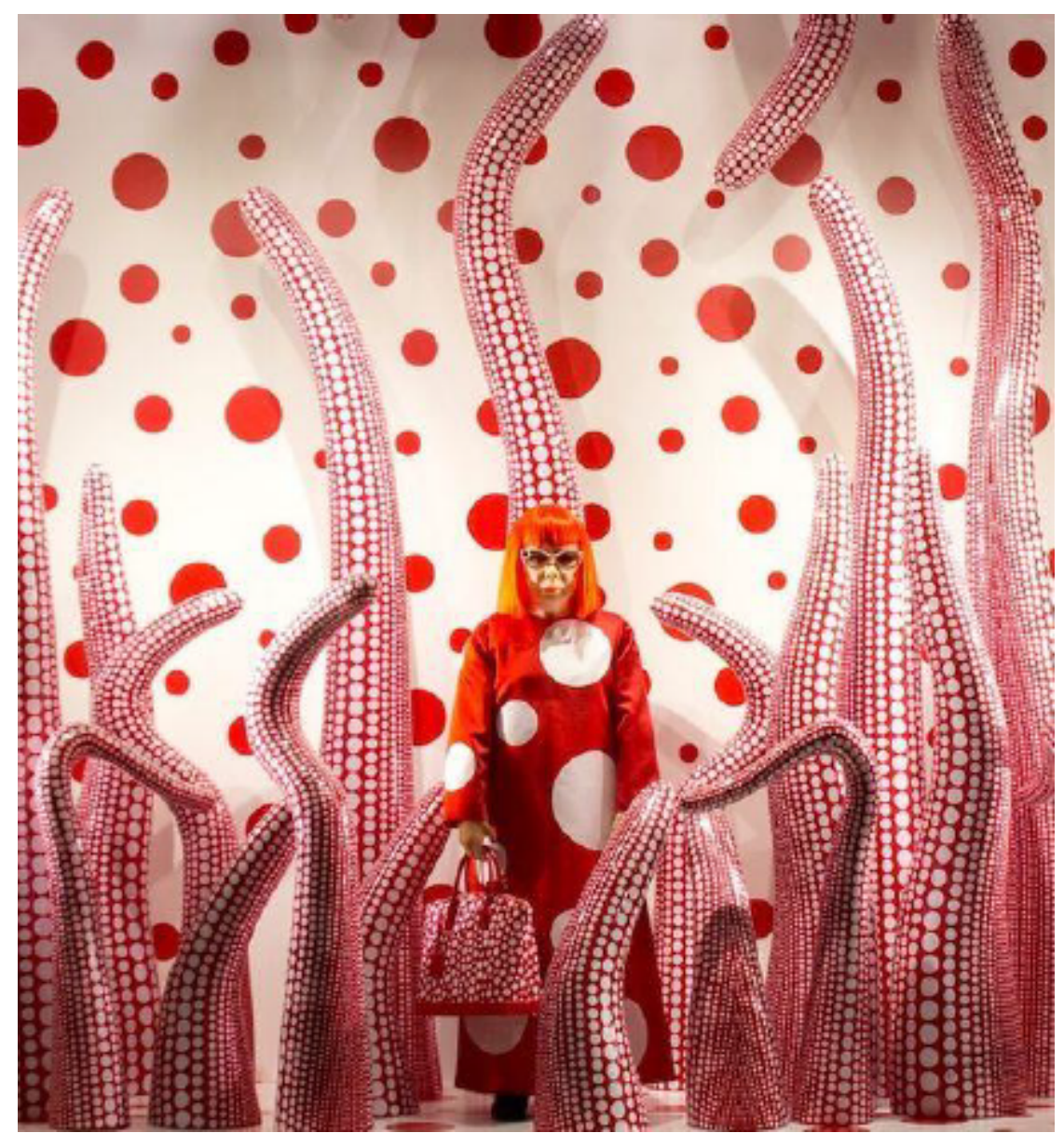

Figura 4 - Coleção Cápsulas, Louis Vuitton.

Fonte: Photo (C Victoire Miro, 2013. Disponível em: < http://www.art- agenda.com/shows/victoria-miro-mayfair- presents-yayoi-kusama/ > Acesso 12 junho 2017.

O ano é 2012. Entre idas e vindas, se esquivando da morte de primaveras e de verões, evitando outonos e invernos outrora já ressuscitados pela moda, atrás de inspiração o design Mark Jacobs (figura 2) chega à Tóquio para conhecer o atelier de uma artista tida como louca, na época em ascensão, a japonesa Yayoi Kusama. Não tão tarde, a próxima coleção da grife Louis Vuitton faz, no ano seguinte, sua estréia em colaboração com a estética artística de Kusama. Surgem assim roupas e acessórios estampados com as inconfundíveis bolinhas e falos de Kusama, por sua vez exibidas nas vitrines das lojas da maison francesa (figura 3), desde a $5^{\mathrm{a}}$ Avenida em Manhattan à Bond Street, em Londres. Um ano mais tarde, a obra White $N^{o} .28$ (1960), pintura de Kusama da série “Infinity Nets" é a obra de uma artista feminina mais cara já leiloada atualmente, vendida por US \$7,1 milhões no leilão de 2014 da Christie ' ${ }^{25}$. Diante a tanto, reiteremos nossa pergunta: como

25 Conforme informa a jornalista Kelly Crow do Wall Street Journal, edição de 12 novembro de 2014. 


\section{Eu, Yayoi Kusama, que pintei minha obliteração, minha obsessão e minhas fobias}

a persona/corpo de Yayoi Kusama (outrora mulher e estrangeira excluída da cena pop cultural artística norte-americana) pôde, hoje, coabitar entre os gênios-loucos do inabitável establishment das artes internacionais?

Parece-nos que a posição que Kusama ocupa hoje nessa esteira discursiva advém de um gesto de resistência pessoal admitido/construído pelos olhos seus e da mídia. Uma parcela do sujeito Kusama (o sujeito empreendedor multimidiático) administra o Kusama World: plataforma mundial na qual a outra parcela do sujeito Kusama (o sujeito expressão-artística de seu próprio saber, a loucura) segue aí exposto enquanto obra- prima. Assim, ao pontuarmos a identificação desse dispositivo (o Kusama World) atravessando e religando as manifestações da "verdade-arte" de Kusama no establishment das artes plásticas contemporâneas, é que observamos na propagação da(s) forma(s) desse sujeito (outrora negligenciado, hoje aclamado) destacar-se uma - até então - uma linguagem estética ímpar: a narrativa episódica dos pontos infinitesimais aplicados em abordagens seriais, instalações espelhadas, animais, corpos nus, abóboras e falos. Eis a interpretação obsessiva do mundo contemplado pela artista Yayoi Kusama.

No entanto, ainda que o sujeito Kusama faça uso do Kusama World para projetaros seus saberes pessoais (a loucura em sua(s) forma(s) estética(s), diante dos poderes- saberes próprios do establishment, indiferente à forma que queira/venha a assumir para ocupar a posição do "artista-louco" que aí se pressupõe, o sujeito Kusama só o faz sendo também autorizada. Ora, estamos diante de uma esteira cuja ocupação é regida e espraiada por micropoderes e que requer consigo a atuação no palco dos jogos de governamentalidades, não nos esqueçamos. É ai que trazemos à tona a fala do sujeito que admite/emparelha a produção pessoal histórica de Yayoi Kusama enquanto artista- louca no establishment em sua atualidade.

Para Frances Morris ${ }^{26}$ (1954-), inscreve-se no portfólio da artista de 87 anos, no qual vida pessoal e profissional se editam profundamente imbricados, um percurso tão extenso, e peculiar, quanto as temáticas abordadas em escala industrial pela artista nipôni-

26 Curadora chefe de coleção e responsável pelo departamento de arte internacional da Tate Modern. Trata-se do museu britânico de arte moderna, inaugurado no ano 2000, pertencente ao grupo Tate, conjunto de quatro galerias de arte: a Tate Britain, a Tate Liverpool, a Tate St. Ives e a Tate Online. 


\section{Eu, Yayoi Kusama, que pintei minha obliteração, minha obsessão e minhas fobias}

ca ao longo de sua vida. Vida e carreira (produção pessoal histórica) assim são perfiladas pela autonomia de uma governamentalidade, além de decorrerem marcadas por desejos cunhados sob formas ilusórias, esses viabilizados pelas técnicas de si desde o sujeito "artista-anônimo" ao sujeito "artista-louco" mundialmente reconhecido. Pontuemos a seguir algumas passagens relevantes da biografia de Kusama, essa admitida por Morris, a fim de estabelecermos o gesto autônomo que promoveu ao sujeito Kusama um acontecimento exemplar, sua irrupção no establishment, para estabelecermos quais seriam as relações de poder-saber aí implícitas no jogo que estabelecemos a partir do exercício da governamentalidade e das técnicas de si.

Conforme assevera Morris em Yayoi Kusama. Obsessão infinita (2013), a precoce trajetória artística de Kusama principia esboçada desde os cadernos de desenho observacionais produzidos na adolescência às participações em bienais na Europa e no Brasil. Em sua busca por reconhecimento, em 1951 a artista nipônica embarcou num diálogo intenso e sustentado pelo movimento surrealista explorando as "lições técnicas e estéticas oferecidas por Joan Miró, Max Ernst, André Masson e Paul Klee ${ }^{27 ”}$ (MORRIS, 2013, p. 36-37).

Posteriormente, figura-lhe inclusive a administração de seu ativismo em protestos nudistas nos movimentos da cultura jovem underground dos anos 1960, nos Estados Unidos da América, seu lar por duas décadas graças ao intermédio de sua amigacorrespondente, a pintora norte-americana Georgia O'Keefe. Entre mudanças significativas de marcha, ascensões, apagamentos pessoais e profissionais, longe da estética oriental de estúdio a artista multifacetada acabou por suplantar os estilos tradicionais da pintura japonesa figurativa (estilo Nanga da dinastia Edo do século XVIII) pela abstração biomórfica, gestual e escultural contemporâneas ocidentais. Apreenderíamos aí a renúncia de uma parcela do si de Kusama (parte de seus saberes pessoais artístico-acadêmicos orientais) ao preço da adoção da produção de uma nova face de Kusama, essa não mais em resistência mas sim em sintonia aos poderes-saberes que a subjetivariam/objetivariam como artista da/na cena pop cultural norte-americana?

27 Entre 1945 e 1952, durante a ocupação americana do Japão, Kusama obteve acesso a informações sobre artistas americanos tendo acessado seus endereços através de centros culturais administrados pelo USIS (Serviço de Informação dos EUA), os quais possibilitavam o intercâmbio cultural entre os Estados Unidose o Japão. Dentre esses artistas, Richard Callahan e Georgia O'Keefe auxiliaram-na a concretizar seus planos de viajar aos Estados Unidos. 


\section{Eu, Yayoi Kusama, que pintei minha obliteração, minha obsessão e minhas fobias}

Prossigamos. Nos cadernos de notas de Kusama e na sua subsequente autobiografia (Infinity Net, The Autobiography of Yayoi Kusama, 2011) seu amplo contexto artístico (o qual compulsa em experimentos técnicos plásticos, esculturais e refúgios literários) registra-se intercalado com notas de desespero, alucinações, tentativas de suicídio e internações. É nesse período de sua vida que vemos o sujeito Kusama não mais apenas regido pelos poderes-saberes do establishment das artes.Nessa época, de seu percurso pessoal/ profissional destaca-se sobremodo o seu quadro psicológico: em 1961 Kusama "teve suas primeiras sessões com o psicanalista freudiano japonês baseado em Nova York, Yasuhiko Taketomo, que diagnosticou o caso da artista como "transtorno obsessivo compulsivo" (MORRIS, 2013, p. 46).

Até então, o sujeito Kusama que escandimos aqui é aquele cuja forma ainda não ocupou a posição do artista-louco no establishment. Noutras palavras, trata-se da parcela da artista, aquela mulher estrangeira em busca de um lugar no cenário pop das artes em ebulição na América dos anos 1960. E refere-se a essa parcela daquelas que compõem o si de Kusama que é excluído do establishment. Em 1966, lutando para manter-se nesse meio, a artista encena sua obra "ao vivo" instalando o Jardim de Narciso ${ }^{28}$ nos pátios da Bienal de Veneza, na Itália. Porém, a recepção de sua obra não foi àquela esperada por Kusama.

$\mathrm{Na}$ ocasião, rodeada por 1.500 globos espelhados lançados pelo gramado, ela, vestida num quimono dourado, distribuía cópias de uma declaração atestando o seu talento, escrita pelo crítico britânico Herbert Read. Juntamente à sua performance, propunha à venda dos mesmos globos numa faixa onde se lia "Seu narcisismo à venda".A ação, controversa na época em que muitos comentaristas pontuavam a crescente dominação de artistas comercialmente bem-sucedidos no âmbito da Bienal (tradicionalmente não comercial), ocasionou sua demissão sumária do espaço da exposição, bem como aquele do establishment.

Logo, de volta à América apagada da cena pop artística local e internacional, e também em decorrência da prescrição médica que recebeu a respeito da forte síndrome de despersonalização já tratada desde a infância, Kusama se vê obrigada a retornar permanentemente ao Japão no início dos anos 1970. Uma vez no Oriente, já à beira da estafa,

Tradução livre nossa de Narcissus Garden. 


\section{Eu, Yayoi Kusama, que pintei minha obliteração, minha obsessão e minhas fobias}

"ao retomar seus contatos em Tóquio, percebeu a família, antigos amigos e contatos de negócios ressabiados por causa de sua fama de escandalosa" (MORRIS, 2013, p. 54). Não obstante, após um período de saúde precária e a mercê de impulsos suicidas, Kusama, por vontade própria "fixou residência nas dependências abrigadas de um hospital psiquiátrico em 1977 [o Seiwa Hospital for the Mentally, em Tóquio] e durante alguns anos parecia que a persona pública da artista havia se aposentado.” (MORRIS, 2013, p. 54). É aí que observamos os poderes-saberes psiquiátricos tomaremo sujeito Kusama - artista anônimo - para si.

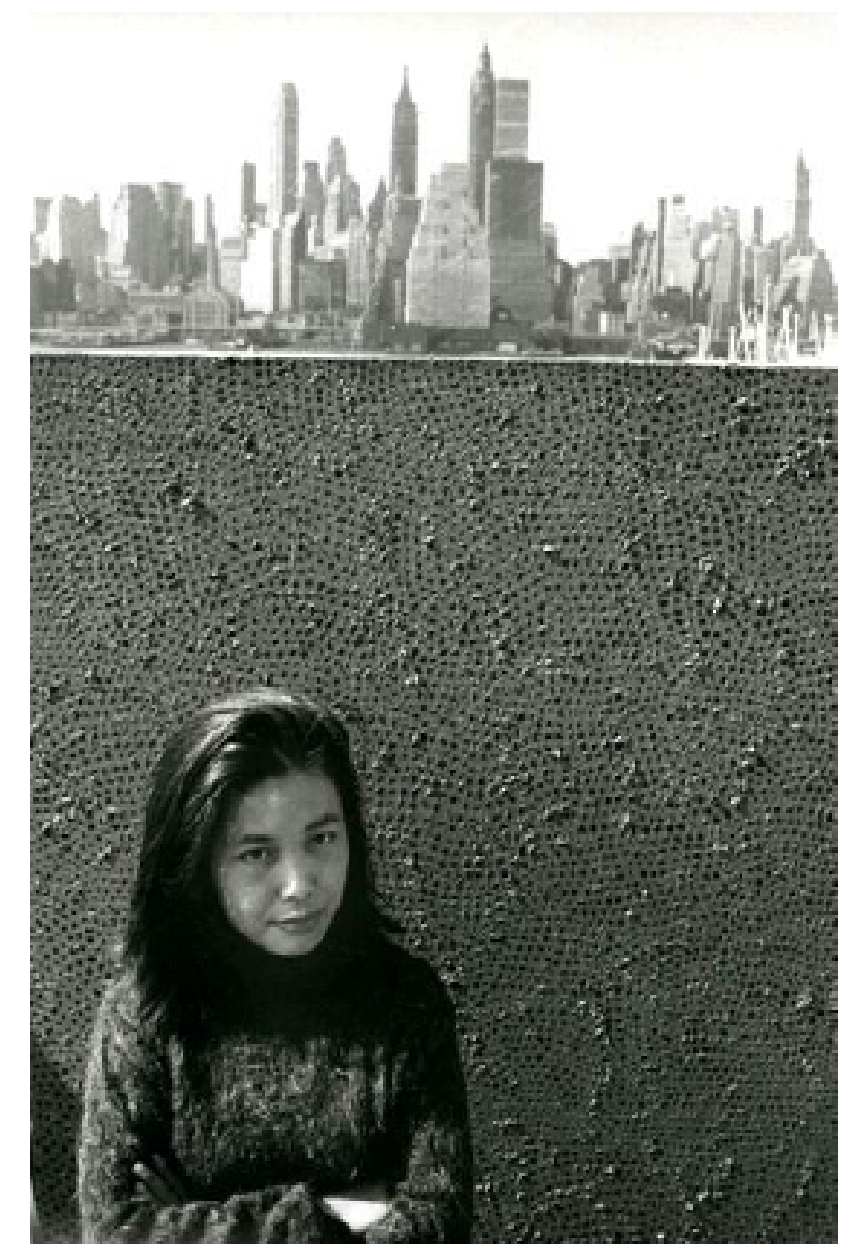

Figura 5 - Kusama antes do diagnóstico psiquiátrico (Nova York, 1961) Fonte: MORRIS, 2013, p.121.

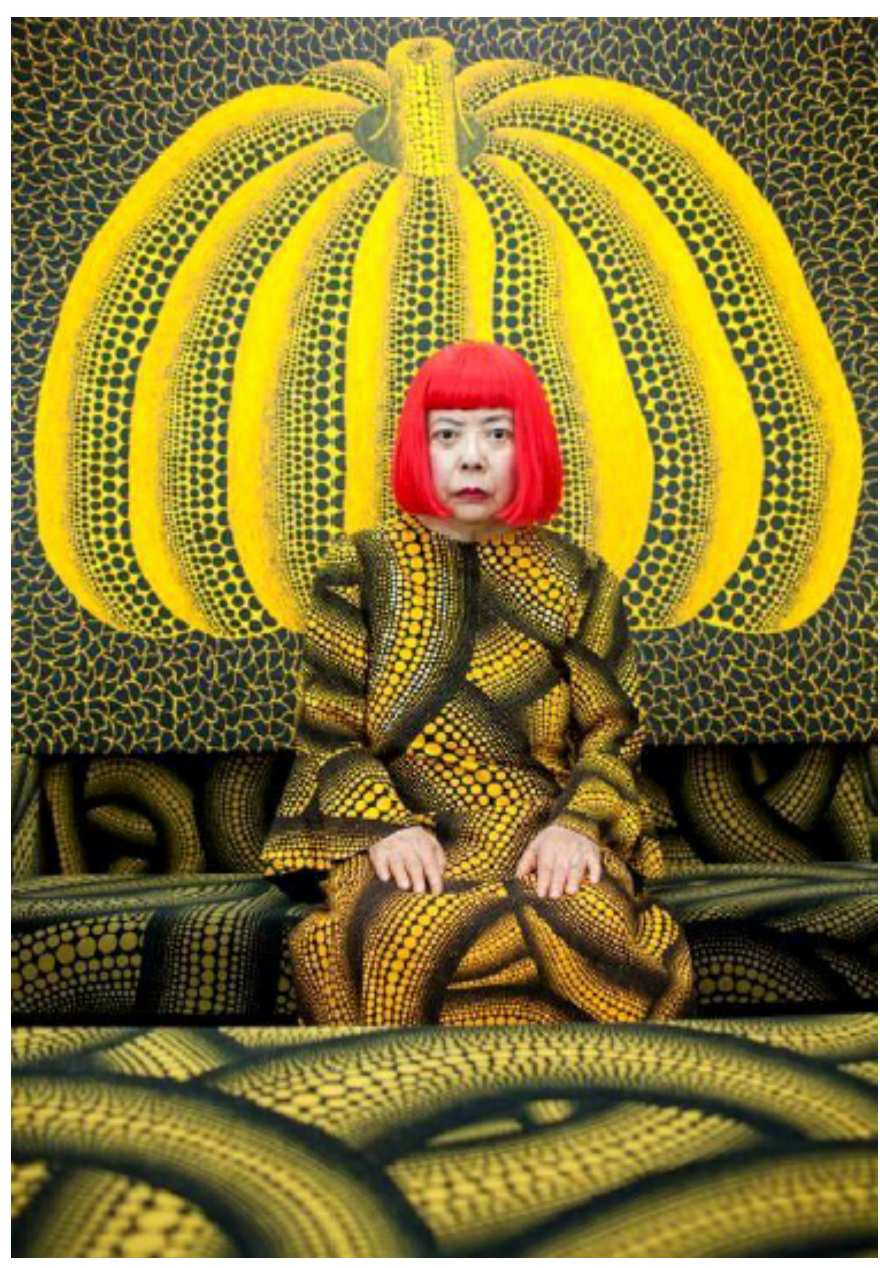

Figura 6 - Kusama após o diagnóstico psiquiátrico (Tókio, 2014) Fonte: Photo (C) Noriko Takasugi, $2014^{29}$.

Porém, por meio dessa auto-internação numa instituição psiquiátrica (mediada pela parcela do sujeito Kusama, essa que agora se projeta como louco aos olhos damídia (figura 5) - em sacrifício pela parcela do sujeito Kusama dos primeiros anos em Nova

29 Disponível em: < https://br.pinterest.com/pin/327425835399809349/> Acesso 12 junho 2017. 


\section{Eu, Yayoi Kusama, que pintei minha obliteração, minha obsessão e minhas fobias}

York (figura 4) é que percebemos irromper também a nova parcela do sujeito Kusama aos olhos do establishment. Ademais, em se tratando da figura do louco seruma posição recorrente na história da arte, ao assumir-se/ser atestada "louca", teria com isso Kusama executado seu grande gesto autônomo exemplar? Com efeito, provavelmente sim.

Ora, daí em diante, aprofundando seu interesse e ofício na própria patologia ${ }^{30}$, essa nova parcela do si do sujeito Kusama "passa a explicar sua arte como produto de psicose infantil, marcada por experiências de alucinações que ela atribuía a abusos e infortúnios na infância" (MORRIS, 2013, P. 46). Para tanto, a artista japonesa sai todos os dias por algumas horas a fim de trabalhar em seu estúdio situado em Shinjuku, bairro nas proximidades do hospital em que reside em Tóquio, por sua vez, esse gerenciado por sua equipe (artesãos, fotógrafos, e assessores do escritório Kusama World). Na intimidade de seu estúdio, sede do Kusama World, ao resgatar o desenvolvimento de suas pinturas da série Net e esculturas da série Acumulações, segundo Morris - autoridade dos poderes-saberes do establishment que, agora autoriza a forma desse sujeito Kusama (o artista-louco), por fim Kusama

demonstrou um esforço pessoal prodigioso combinado com um apetite insaciável de exposição pública: em 1980, sete anos após seu retorno ao Japão, realizou cinco exposições individuais. Em 1982, com a reputação amplamente restaurada, conseguiu patrocínio da Galeria Fuji Television em Tóquio e seu novo trabalho foi exposto à aclamação cada vez mais crescente durante a década. Foi um período em que os falos de suas Acumulações se transmutaram em esculturas de múltiplas partes e grande formato, com apêndices contorcidos semelhantes a tentáculos. Em suas pinturas, a série Net deu lugar a novos tipos de marca e a sua grife de bolinhas, a espermatozoides contorcidos ou sementes germinantes, muitas vezes em escala considerável (MORRIS, 2013, p. 54).

Logo, diante dessa referida escala (culminação de toda uma produção histórica pessoal), é que tecemos duas importantes considerações para o cenário que escandimos sobre o sujeito Kusama. De um lado, apreende-se uma parcela desse sujeito, a qual, mediada pelos seus saberes pessoais manuseia estrategicamente a própria patologia como uma

30 Tem-se o primeiro relato de Kusama acerca de suas experiências de alucinação, auto-intituladas "auto- obliteração" na infância, no qual explica sua arte como "baseada na inevitabilidade que surgiu dentro de mim", publicado em Wagatamashii no henrekitotatakai(Odisseia de Minha Alma em Conflito), Geijutsuseikatsu(Arte e Vida), Tóquio, novembro de 1975, pp. 96-113. 


\section{Eu, Yayoi Kusama, que pintei minha obliteração, minha obsessão e minhas fobias}

projeção estético-artística via Kusama World. Nesse jogo, essa parcela assim resiste aos poderes-saberes do establishment. Do outro, em decorrência de todas essas formas do "novo" sujeito Kusama, essas que simultaneamente são admitidas pela figura de Morris, autoridade no establishment que depende e também se insere numa era de conectividade global política, econômica e global ininterruptas, é que vemos Kusama ocupar com sucesso a posição de artista-louco nesse meio, finalmente. Irrompe assim o sujeito Kusama "artista-louco" adejando construído e construindo-se na figura de sua extraordinária persona pública, postulada com tal pelo Kusama World e autorizada a tanto pelo establishment.

O que se apreende do que foi dito ao pensarmos nos termos de governamentalidade e das técnicas de si, é a visibilidade da construção de um sujeito comprometido com a autopromoção e que outrora foi "impedida, por questões degênero e raça, de fazer parte do núcleo da arte Pop americana" (MORRIS, 2013, p. 50) e que hoje se transforma numa persona imediatamente reconhecível, quer o seja como um produto sedutor para platéias do mundo inteiro via o Kusama World, quer o seja reconhecida como sujeito "artista-louco" em posse/construção da "verdade-arte" concedida tanto pelos poderes-saberes seus, como por aqueles do establishment.

Em síntese, destacamos que a figura de Kusama se emaranha numa tessitura artística atrelada ao ofício da loucura, a qual por sua vez decorre: primeiramente, afiançada desde a verve erótica reprimida na infância - segundo os poderes-saberes psiquiátricos. Em segundo, por administrar um saber pessoal - forma de resistência haja visto sua empreitada associada ao que aqui chamados de dispositivo KusamaWorld. E, finalmente, o faz seguindo autorizada no/pelo establishment das artes contemporâneas na como "artista-louco" na posição de "Suprema Sacerdotisa das Bolinhas ${ }^{31}$ " de cujo saber pessoal sobre o mundo, descreve:

desejei prever e avaliar a infinitude de nosso vasto universo com a acumulação de unidades de rede, uma negativa de pontos. Quão profundo é o mistério do infinito sem fim em todo o cosmos. Enquanto apreendo isso tudo, quero enxergar minha própria vida. Minha vida, um ponto, ou seja, uma em meio a milhões de partículas. Foi em 1959 que me manifestei sobre [minha arte] obliterar a mim e aos outros com o vazio de uma rede tecida com uma acumulação astronômica de pontos (KUSAMA, 2006, p. 110).

31 Título atribuído a artista pela revista The Village Voice, em 28 de novembro de 1968. 


\section{Eu, Yayoi Kusama, que pintei minha obliteração, minha obsessão e minhas fobias}

Delineada, grosso modo, a carreira da artista segundo Morris, percebemos tangendo à persona de Kusama uma sugestão do gesto epimeleisthaisaltou - o cuidado de si, esse intrinsecamente associado aos jogos decorridos pela ordem da governamentalidade. Isso por, percebermos o sujeito de Kusama associar-se a um estado político que expressa coisas, relações, ações mais sérias do que superficialmente em princípio aparentam (a exemplo das temáticas artísticas e técnicas assumidas por Kusama). Soma-se a isto o estabelecimento de práticas racionais e regulares (o exercício diário da pintura empenhado pela artista, promovido pelo seu dispositivo-plataforma Kusama World) as quais, desse modo, ordenam a composição de Yayoi Kusama próxima à estrutura do sujeito pensado por Foucault em sua genealogia ética das técnicas de si (a postura que o sujeito assume para si) que atua no jogo de forças estabelecidas por poderes-saberes, nesse caso atravessadas pelo embate dos discursos psiquiátrico e do establishment contemporâneo.

Estabelecidas tais conjecturas, desse modo acenamos para a inscrição do sujeito Kusama "artista-louco" irrompendo no establishment graças a sua autopromoção via auto-internamento e o gerenciamento de sua plataforma multimidiática. Destaca-se assim sua loucura registrada como "verdade-arte", muito representada em abrangência às estéticas da psicodelia e da repetição. Logo, tais padrões que, expressados em suas obras - enunciados pictóricos, plásticos e esculturais - fazem remeter a persona/corpo Kusama à construção de uma subjetividade firmada por meio do ofício da loucura, exercício que, no entanto, diz respeito a uma posição que pode vir a ser ocupada por um determinado sujeito. Se hoje Kusama ocupa tal posição, ela outrora já foi reclamada por outro "artista-louco".

Dito tudo isso, também é preciso que se reflita sobre a "verdade" que é moldada/ produzida/manobrada pelos poderes-saberes do establishment. Para tanto, em nossa análise consideramos então crucial levantarmos duas questões derradeiras. Diante do oficio da loucura, haveria quais transformações nesse establishment, ou melhordizendo: seria possível, em termos de enunciado e materialidade discursiva interpretarmos numa obra-prima qual sucessão de indícios da loucura - ofício da posição "artista-louco"? Assim sendo, sob quais máscaras e redes de reminiscências pessoais e de memórias coletivas a atualidade do sujeito "artista-louco" ainda manteria seu rastro histórico admitindo-se/ construindo-se (ou não) como tal aos olhos da crítica e da mídia? 


\section{Eu, Yayoi Kusama, que pintei minha obliteração, minha obsessão e minhas fobias}

Tendo exposto o gesto autônomo exemplar de Kusama, que assim como para Pierre Rivière, tais "atitudes" em confronto aos embates discursivos foram tornadas possíveis por meio do gerenciamento da governamentalidade e das técnicas de si, nesse passo, a fim de elucidarmos os questionamentos levantados, nesse passo aprofundaremos as relações de poder-saber implícitas a persona/corpo Yayoi Kusama - máscara - que hoje coabita entre os gênios-loucos do até então inabitável establishment das artes internacionais. Para tanto, começos nossa abordagem a partir do conceito "verdade", primeiramente.

\section{Perícia artística - a passagem da verdade pelo exame do olhar:}

\section{O savoir-faire das verdades "demonstrada/acontecimento"}

O público que vai aos museus contemplar as mais diversas expressões de arte, lá aprecia o que lhes é exposto ou aquilo que lhes é imposto como tal? Como se dá a percepção/manutenção do conhecimento que atravessa, de um lado da via, a obra de arte e seus próprios dizeres, e do outro, o público que a recepciona? Ora, cerceando os limites assegurados pela posição-sujeito reservada ao público nesses lugares, que assim posicionados apreciam ou criticam as obras que lá vêem, é preciso aí distinguir não uma, mas sim duas formas de posicionamento, ou seja, dois sistemas de funcionamento arrolados ao conceito de "verdade", inevitavelmente. Isso porque, de fato, pela perspectiva arquegenealógica foucaultiana há duas verdades em jogo a se ponderar.

Façamos agora alguns apontamentos sobre a manutenção discursiva da verdade, essa delineada conforme o pensamento de Foucault. A fim de evidenciá-la, se torna imperativo discorrermos essa verdade (a loucura proclamada enquanto estética plástica de Yayoi Kusama, nesse caso) a partir de sua pluralidade cuja multiplicidade de significados segue inexoravelmente atrelada aos poderes-saberes que se inscrevem na psiquiatria, no establishment das artes, além da governamentalidade do si do sujeito "artista-louco" Yayoi Kusama.

$\mathrm{Na}$ esteira desse gesto analítico, logo cabe dizer que não se trata então da verificação do estabelecimento de uma reflexão sobre a existência de uma verdade "certa" em detrimento de outra "errada". Ao abordarmos a verdade, interessa antes evidenciar os inú- 


\section{Eu, Yayoi Kusama, que pintei minha obliteração, minha obsessão e minhas fobias}

meros procedimentos de controle e de delimitação do discurso que a atravessam, de um lado - em sua exterioridade - ou seja, aqueles que "funcionam como sistemas de exclusão [e que] concernem, sem dúvida, à parte do discurso que põe em jogo o poder e o desejo" (FOUCAULT, 2009, p. 21) - são eles os princípios de“interdição", "exclusão" e "vontade de verdade" (FOUCAULT, 2009, p. 9-14). E, ainda, do outro se encontram os princípios que a atravessam - em sua interioridade - a saber, os princípios de "comentário", "autor", "organização das disciplinas", "rarefação" e "grupos doutrinários" (FOUCAULT, 2009, p. 22-44), sendo esses

os discursos por eles mesmos que exercem seu próprio controle; procedimento que funcionam, sobretudo, a título de princípios de classificação, de ordenação, de distribuição, como se se tratasse, desta vez, de submeter outra dimensão do discurso: a do acontecimento e do acaso (FOCUAULT, 2009, p. 21).

A respeito dessa dimensão do discurso, o acontecimento, ao analisarmos o caso de Kusama, acreditamos que esse se dá em muito através de sua estética tão particular. Isto é, ele se refere à apropriação da loucura pela Sacerdotisa das Bolinhas que se admite ciente de/em sua patologia, e que, aos olhos dos poderes-saberes do establishment e da mídia assim consuma os gestos rituais do ofício artístico da loucura (essas mais conscientemente proferidas depois de sua auto-internação no centro psiquiátrico). Como é de se esperar, diante de tantas camadas discursivas ligadas aos procedimentos internos e externos regidos por poderes e saberes que reclamam todos a loucura para si, sobre esse "produto" artístico fruto da obsessiva ocupação de Kusama pairam muitas controvérsias. Dito isso, verifiquemos como se dá a exposição da verdade sobre essa loucura (patológica e estética) a partir dos discursos psiquiátrico, do establishment e da própria Yayoi Kusama.

Primeiramente, o crítico de arte Philip Larratt-Smith não nega as críticas que vão contra a loucura (patológica) de Kusama. Em seu turno, ele as reconhece, pois, afirma que é

a partir do momento em que Kusama optou por viver num hospital psiquiátrico em 1977, sua condição psicológica foi alvo de equívocose mal entendidos. Tanto a sinceridade como a validade de suas alegações de que a doença é o manancial de sua arte têm sido questionadas (LARRAT-SMITH, 2013, p. 72). 


\section{Eu, Yayoi Kusama, que pintei minha obliteração, minha obsessão e minhas fobias}

No entanto, em resposta às críticas tanto sobre a veracidade da loucura (patológica) como a expressão da loucura (estética) materializada na obra de Kusama, em Canção de uma eterna suicida (2013), Larratt-Smith busca elucidar a "natureza específica da doença de Kusama: as alucinações, a neurose obsessivo-compulsiva, o transtorno de despersonalização e a depressão que acometem a artista desde menina” (SMITT, 2013, p. 72). Assim, somado ao diagnostico de 1961 do doutor Takemoto (poderes-saberes da psiquiatria) é que notamos enredar-se à história da verdade sobre a loucura (patológica) de Kusama a produção de uma verdade segunda; àquela de cunho estético. Por sua vez, ela advém diretamente dos poderes-saberes do establishment. Já para o desenvolvimento desse esclarecimento, Larrett-Smith resolve "tratar do assunto diretamente [ao incluir] nesse texto trechos de estudos clássicos de outros neuróticos compulsivos como pano de fundo (características gerais dessa neurose) para a discussãoda especificidade patológica da obra da artista" (SMITT, 2013, p. 72).

Assim, intercalando passagens teóricas de teor arrolado aos sintomas do quadro patológico sofrido por Kusama com trechos de suas declarações públicas, Larret-Smitt tece a construção de uma produção de sentidos sobre a doença da artista, pressupondo, por meio desse recorte, o veredicto da verdade plástica (essa decorrente do quadro patológico) de Kusama. Englobando seu traço estético peculiar, em linhas gerais, Larrett-Smitt se pergunta se as bolinhas de Kusama são uma forma de mimetismo; se representam em sua rede imagética o espaço positivo ou negativo; se a recorrência de seu gesto de auto-obliteração é decorrência do narcisismo ou da auto-preservação; se Kusama em seu ofício está fugindo ou se está indo de encontro com a morte.

Como resultado desse ritmo de ideias, Larrett-Smitt estabelece em seu texto a construção de um mosaico patológico-artístico de/em Kusama. Eis que assimapreendemos elencadas a fabricação de três posições de verdade: a primeira embasada no discurso psiquiátrico de Freud, conforme lida por Paul Moyaert, a segunda embasada no establishment das artes contemporâneas pelo próprio curador Larrett-Smitt, e como desfecho, ainda encontramos o ponto de vista da própria loucura, esse proferido diretamente de Kusama. Da seleção desses discursos que atravessas a loucura (patológica) de Kusama, sobre os poderes-saberes psiquiátricos, apreende-se que 


\section{Eu, Yayoi Kusama, que pintei minha obliteração, minha obsessão e minhas fobias}

o histérico se lança de cabeça em direção ao que pensa desejar, de acordo, pelo menos, com a sugestão do momento, ao passo que o neurótico compulsivo atua no sentido de adiar indefinidamente a consumação do que deseja, que oculta, repudia. ("os sintomas focam na satisfação sexual ou no repúdio e... de maneira geral, o caráter positivo de realização de desejos prevalece na histeria e o caráter negativo e ascético, na neurose obsessiva." [citação de Freud ${ }^{32}$ ]) O prazer sexual vem a representar a ameaça da desintegração psíquica porque pressupõe a perda temporária da individualização, uma perspectiva que produz ansiedade intensa. "O que assusta é que, no prazer, uma força impessoal - de gozo (jouissance) - se torna dominante, uma força que... se expressa na perda de si mesmo. O prazer do neurótico obsessivo é continuamente prejudicado pelo medode seu próprio gozo, ou seja, de sua perda e entrega de si mesmo. O neurótico obsessivo precisa se segurar, por aquilo que talvez não aconteça se ele realmente se entregar? Por medo de conseqüências imprevistas para si e para os outros, o neurótico jamais diz 'sim' (citado em Moyert, apud SMITT, 2013, p. 81).

Conseguintemente, arrolado à alusão feita sobre o quadro patológico de Kusama, dos poderes-saberes do establishment artístico, sobre a loucura (estética) de Kusama Larrett-Smitt reitera que

Kusama é fortalecida pelo mal do verdadeiro artista. A artista é uma eterna suicida cuja necessidade compulsiva de transformar a si mesma e sua vida em obra de arte afasta o medo da morte e da desintegração psíquica, garantindo sua imortalidade. A peculiar doença da qual sofreu a vida toda forçou-a a entrar em um mundo simbólico de sua própria autoria. Criou espaços que nos fazem experimentar mecanismos contraditórios, mas amalgamados, de sua mente inconsciente. Nas palavras de Thomas Mann, "não há conhecimento mais profundo sem a experiência da doença [de que] todo aumento de sanidade deve ser alcançado pelo caminho da doença (SMITT, 2013,p. 92).

Concomitante aos excertos supracitados, no tocante à aproximação dos poderessaberes psiquiátricos (a construção do sujeito neurótico obsessivo) e do establishment (osujeito verdadeiro artista cuja vida e obra se amalgamam), essa experiência da doença vivida por Kusama de forma estética (a construção do sujeito em confronto com os poderes-saberes por meio da prática do governo de si) tem assim sua medida e veracidade também fabricada com base nas alegações da própria artista-louca: “a mais drástica ideia de forçar o público a passar... confiança é a fantasia inconsciente de castrar o público... 'Nenhum de vocês têm pênis. Eu, no papel de uma pessoa castrada, estou mostrando a vocês como vocês devem agir." 33

32 Ibid Paul Moyaert, What is Frightening about Sexual Plesure?, p 32.

33 Declaração de Yayoi Kusama em Fenichel, "On Acting” in Collected Papers, Ibid., p 359-360, 


\section{Eu, Yayoi Kusama, que pintei minha obliteração, minha obsessão e minhas fobias}

Apresentadas as redes discursivas de poderes e saberes em que se emaranham a verdade estético-patológica de Kusama (o poder psiquiátrico, o poder do establishment, a verdade no governo de si do sujeito Kusama), reforçamos que não buscamos desvendar a "verdade" sobre a patologia do sujeito Yayoi Kusama. Longe disso, buscamos mostrar as verdades plurais que fazem parte do processo de sua fabricação subjetiva por meio dos conceitos arque-genealógicos ensinados por Foucault.

Não obstante, ainda é necessário explanarmos as raízes do conceito de verdade que Foucault delineia enquanto verdade-demonstração e verdade-acontecimento para referenciarmos as características do saber científico (ou não) da "verdade-arte" diante dos poderes-saberes que analisamos nesta pesquisa. Prosseguindo com a discussão, de início trazemos à tona o conceito de verdade estabelecido por Foucault em O poder psiquiátrico (2006a), curso dado no Collège de France entre 1973 e 1974. Dando prosseguimento às questões abordadas em A História da loucura, nesse texto Foucault trata da elaboração da genealogia da psiquiatria, ou seja, da forma própria de poder-saber que ela constitui.

Asseverando impossível partir do que seria um saber médico sobre a loucura por considerá-lo inoperante na prática, Foucault constata que só se pode dar ciência da veridicção psiquiátrica sobre a loucura a partir de determinados dispositivos e das técnicas de poder que, em seu expediente, organizaram o tratamento dos loucos. Por fim, Foucault constata que a psiquiatria não nasce como consequência de uma progressão nos conhecimentos da loucura; ao contrário, ela nasce dos dispositivos disciplinares nos quais se tem organizado o regime imposto à loucura.

Resumidamente, Foucault cerceia a verdade para o saber científico como aquela que está posta sempre presente em toda coisa ou sob toda coisa. Isso, pois, a propósito de tudo e de qualquer coisa, é possível colocar a questão da verdade. Essa posição filosófica-científica da verdade para Foucault está ligada a uma tecnologia da construção, ou melhor dizendo, da constatação em direito universal da verdade. É a prática científica compreendida como "tecnologia da demonstração" (FOUCAULT,2006a, p. 302). Isto é, sobre a verdade

apudLarratt-Smitt, 2013, p. 100. 


\section{Eu, Yayoi Kusama, que pintei minha obliteração, minha obsessão e minhas fobias}

para o saber científico, nunca há nada que seja suficientemente tênue, fútil, passageiro ou ocasional para não concernir à questão da verdade [...] para que não se possa lhe fazer a pergunta: o que é você em verdade? A verdade [universal] habita tudo e qualquer coisa [...], todae qualquer parte [...] mas [isto] quer dizer também que não há ninguém que seja exclusivamente qualificado para dizer a verdade [...] a partir do momento em que, é claro, se disponha dos instrumentos necessários para descobri-las, as categorias necessárias para pensá-la e a linguagem adequada para formulá-la em proposições (FOUCAULT, 2006a, p. 302).

Todavia, oposta a verdade-demonstração, para Foucault está a verdade-acontecimento, ou seja, trata-se de um posicionamento de uma verdade, a qual justamente por isso não estaria em toda a parte, nem em todo o tempo a nossa espera, a fim de que a espreitássemos e a aprendêssemos onde quer que ela estivesse. Sobre essa verdade dispersa, Foucault estabelece que

é uma verdade que tem seus instantes favoráveis, seus lugares propícios, seus agentes e seus portadores privilegiados. É uma verdadeque tem sua geografia [...] que tem também calendário ou, pelo menos, sua cronologia própria. [É também] uma verdade que tem seusmensageiros ou seus operadores privilegiados e exclusivos. [Estes]são os que pronunciam as palavras requeridas ou consumaram os gestos rituais, [são] aqueles que a verdade escolheu para se abater sobre eles: os profetas, os adivinhos, os inocentes, os cegos, os loucos,os sábios, etc. (FOUCAULT, 2006a, p. 303304).

Como se depreende, a verdade-acontecimento não é uma verdade universal, tão pouco é uma verdade rara. Antes é uma verdade dispersa. E para ela, não se trata, portanto, da verificação de um método, mas sim da percepção de uma estratégia. Logo, a relação que se apreende entre a verdade-acontecimento e o que é atingido por ela, segundo Foucault, não é da ordem do objeto ao sujeito, uma relação de conhecimento. É antes de tudo uma "relação de choque [...] da ordem do raio ou do relâmpago, [...] da ordem da caça, [...] reversível, belicosa, é uma relação de dominação e de vitória, não portanto uma relação de conhecimento, mas de poder" (FOUCAULT, 2006a, p. 303- 304). Como desfecho da proposta foucaultiana para a verdade, em respeito à figura do sujeito universal arrolado a ela, esse nada mais é que um indivíduo historicamente qualificado de acordo com certos números de materialidades, pois, para Foucault "a descoberta da verdade é na realidade certa materialidade de produção da verdade [...] para o sistema da verdade-acontecimento - é isso que chamarei Arqueologia do saber" (FOUCAULT, 2006a, p. 305-306). 


\section{Eu, Yayoi Kusama, que pintei minha obliteração, minha obsessão e minhas fobias}

Arrolemos agora o conceito de verdade à esteira dos poderes-saberes que contornam o sujeito "artista-louco". Conforme apreendemos a "verdade-arte", vimos que esta atravessa o establishment o qual jaz imersa, como, por exemplo, seguindo veiculada ao Kusama World; além também de estabelecer-se na disputa dos jogos de verdade, atravessando assim o exercício da governamentalidade e das técnicas de si exercidas pelo sujeito aqui escandido. Logo, em respeito à figura do curador, tal como Francis Morris ou Larratt-Smitt, cumpre dizermos aí estabelecida uma "verdade-arte"da ordem verdade-demonstrada, ou seja, vemos esse sujeito em certa "posição filosófico-científica da verdade que é ligada a certa tecnologia da construção ou da constatação universal da verdade, uma tecnologia da demonstração" (FOUCAULT,2006a, p. 302).

Já a "verdade-arte" que se aproxima dos enunciados referidos ao sujeito Yayoi Kusama, ela se dá mais como uma verdade-acontecimento cuja instância também perpassa a verdade-demonstração. Com isso, queremos dizer que a estética pictórica produzida pelo sujeito Kusama se tratar de, no establishment, uma produção em posse/construção a partir de agentes privilegiados (aquele que ocupa a posição-sujeito "artista-louco" cujos saberes se confrontam com àqueles daquele que ocupa a posição-sujeito curador de arte). É produção que tem sua geografia (é produzida no estúdio do artista e que se expõe na galeria de arte); que tem sua própria cronologia (hoje, a "verdade-arte" de Kusama ocupa uma posição que outrora ali mesmo apresentou outra "verdade-arte", outro ofício da loucura executado pelas mãos de outro sujeito "artista- louco").

Portanto, por meio desse "novo" sujeito Kusama - a parcela de si que faz jus à renomada artista-louca que vive internada, por vontade própria, num instituto psiquiátrico - ou seja, sujeito elidido de uma parte de si, em renúncia da pretérita artista, a mulher estrangeira que outrora buscou sem sucesso um lugar no cenário pop das artes em ebulição na América, é que apreendemos a "verdade-arte" de Kusama sendo, para o establishment atual, como um acontecimento. Isso por considerarmos as declarações deKusama como acontecimentos irrompidos num determinado momento sócio-histórico (nos Estados Unidos da América, Europa e Japão), e que, como tais, ocasionam rupturas e/ou repetições. Logo, se analisar o discurso como um acontecimento significa, para a AD, olhá-lo através do prisma da história e buscar assim, na materialidade de seus enunciados, 


\section{Eu, Yayoi Kusama, que pintei minha obliteração, minha obsessão e minhas fobias}

enunciados outros (esses viabilizados pela memória), entendemos que o acontecimento aí produzido pelo sujeito Kusama se dá a partir de uma relação de choque, do embate entre poderes-saberes no qual a sua arte (produção) - gerenciada pela governamentalidade de si - expõe-se/é exposta implicando-se como "verdade-arte" de acordo com a posição que segue ocupando nessa esteira discursiva.

Dito isso, tendo mostrado as verdades plurais que fazem parte do processo da fabricação subjetiva de Kusama por meio dos conceitos arque-genealógicos ensinados por Foucault, pontuamos que o status de "novidade" no acontecimento acerca do sujeito"artista-louco" Kusama não é a "verdade" da loucura necessariamente. Trata-se antes da abordagem que o sujeito Yayoi Kusama faz dela; já que paira aí uma

multiplicidade aberta, [em que] o acaso são transferidos, pelo princípio do comentário [o de kusama,...] daquilo que se arrisca de ser dito, para o número, a forma, a máscara e a circunstância da repetição [pois, tão somente] o novo não está no que é dito, mas no acontecimento a sua volta (FOUCAULT, 2009, p. 26).

Uma vez exposto o gerenciamento de saberes acerca dos dizeres da verdade (patológica e estética) de Kusama, voltemos a nossa questão sobre a percepção/manutenção do conhecimento que atravessa, de um lado da via, a obra de arte e seus próprios dizeres, e do outro, o público que a recepciona. Para o desenvolvimento dessa pesquisa, a posição de verdade a qual nos interessa aqui, antes diz respeito àquela ocupada por um determinado sujeito cuja atitude moderna em relação à obra de arte, digamos, lhe autorize ao exercício de um exame do olhar diferente daquele lançado pelos olhos do público - isso justamente dado as distintas posições que ocupam na cena do establishment. Assim, os saberes que aqui devemos considerar são aqueles querepresentem uma atitude de apreciação desde os pormenores até o conjunto da obra, logo, saberes esses respaldados pelo poder que então direciona/atribui uma forma para a "verdade", para o que foi dito e mesmo aquilo que não foi dito sobre tal obra.

Com isso, ainda que o público produza comentários, dizeres esses sobre a"verdade" dita de uma determinada obra, de modo algum eles são autorizados aí, no establishment, a decretar o veredicto "isso é arte, isso não é arte”. Como se sabe, nem tudo pode ser dito, pois todos os discursos se submetem a uma ordem do discurso. E ana ordem do discurso da história da arte, tal decreto "verdade-arte" adeja pertencendo aos poderes-saberes san- 
cionados pelo poder atribuído à figura do curador, poderes arrolados/em dependência da produção dos artistas, que por sua vez, mobilizam ocenário histórico que se assim se constrói. Explicitada a passagem de Kusama da infâmia para a notoriedade por meio da prática de sua "verdade-arte", verifiquemos agora a construção do protagonismo do sujeito Yayoi Kusama de outra perspectiva: àquela da jornada heróica pela senda do establishment cujos vencedores reclamam para si a imortalidade dos artistas aí historicamente mitificados por sua genialidade.

\title{
O savoir-être do "paradigma indiciário"
}

\begin{abstract}
"A personalidade deve ser procurada onde o esforço pessoal é menos intenso [...]: os nossos pequenos gestos inconscientes revelam o nosso caráter mais do que qualquer atitude formal, cuidadosamente preparada por nós." 34
\end{abstract}

Carlo Ginzburg

Tal como vimos atrelado à raiz do conceito de verdade a existência de duas frentes, a verdade-demonstrada e a verdade-acontecimento, convém também mostrarmos que igualmente há nos estudos semiológicos duas tradições, incompatíveis e com durações distintas arroladas à ordem dos saberes da semiologia. Uma delas diz respeito a uma perspectiva antropologicamente deveras antiga, por vezes confundida com a tradição imemorial de interpretação dos indícios. A outra, mais recente, se referea uma tentativa advinda de algumas linhas junto ao pensamento saussureano, em seu turno desenvolvida no estruturalismo francês dos anos 1960 .

Interessa-nos, diante disso, explanar aqui a semiologia enquanto termo pré-existente ao uso saussureano projetado no Curso Geral de Linguística. A semiologia que tratamos aqui, portanto, é aquela cujo emprego tradicional surge nos primórdios da medicina, onde se "designa as técnicas de observação dos indícios que, à superfície do corpo visível, fazem sintoma, isto é, testemunham a presença de tal ou tal entidade mórbida não diretamente observável" (COURTINE, 2013, p. 38). É a partir dessa semiologia que o historiador Carlo Ginzburg (1939-) propõe a emergência daquilo que ele denomina como "paradigma indiciário".

34 Apud Cf. Wind. Arte, cit., p. 62 (GINZBURG, 2014, p 146). 


\section{Eu, Yayoi Kusama, que pintei minha obliteração, minha obsessão e minhas fobias}

Em Mitos, Emblemas, Sinais (2014), no capítulo Sinais. Raízes de um paradigma indiciário, Ginzburg faz incursões pelo mundo da psicanálise e da arte a partir da releitura Freud, Sherlock Holmes e do crítico de arte Morelli, isso à luz da análise morfológica e histórica. Como resultado, o historiador constrói o paradigma de um "saber indiciário", ou seja, um método de conhecimento cuja força reside na observação do pormenor revelador, e não mais no processo de dedução.

Em sua análise, a partir do Jornal de Artes Visuais ${ }^{35}$, em circulação entre 1874 e 1876, Ginzburg chama atenção para o aparecimento do novo "método morelliano" para atribuição da autoria de quadros antigos proposto pelo italiano Giovanni Morelli. Grosso modo, esse método consiste na capacidade de distinguir quadros originais das cópias a partir do exame dos "pormenores mais negligenciáveis, e menos influenciados pelas características da escola a que o pintor pertencia: os lóbulos das orelhas, as unhas, as formas dos dedos das mãos e dos pés" (GINZBURG, 2014, p. 144). Essa atitude em relação à obra de arte, esse ajustamento de seus detalhes ínfimos revelaria ao curador onde a atenção do pintor repousa; e com isso, perceber-se-ia um segmento da extensão da pintura em que a execução não sofreu o automatismo técnico de uma tendência escolástica.

Logo, o método de Morelli confere ao establishment das artes o aspecto de um museu criminal, fazendo com que se aproximasse assim o conhecedor de arte ao papel do detetive que descobre a autoria de um crime. É aí que o método de Morelli se aproxima a esteira literária (de mesma época) de Arthur Conan Doyle, mais precisamente em referência ao célebre e astuto personagem Sherlock Holmes: protagonista caçador de indícios capaz de ver aquilo que os outros não enxergam, ou seja, ele é fluente na linguagem dos indícios. Frente à percepção desse paralelismo que gira em torno de nossos pequenos gestos inconscientes, Ginzburg ainda traz à baila de sua análise da construção da Semiologia Histórica a "genérica expressão "psicologia moderna" [que] pode ser diretamente substituída pelo nome de Freud". (GINZBURG, 2014, p. 146).

O que se apreende disso é a "considerável influência intelectual que Morelli exerceu sobre ele [Freud], numa fase muito anterior à descoberta da psicanálise" (GINZBURG, 2014, p. 147-148). Isso, tendo-se em vista o estreitamento das palavras de Freud às 


\section{Eu, Yayoi Kusama, que pintei minha obliteração, minha obsessão e minhas fobias}

de Morelli segundo o ensaio freudiano, até então anônimo, O Moisés de Michelangelo, no qual Ginzburg estabelece um parentesco entre o método morelliano e as técnicas da psicanálise médica em Freud, pois

na realidade, toda a declaração de Freud [...] garante um lugar especial na história da formação da psicanálise. De fato, trata-se de uma conexão documentada, e não conjectural, como a maior parte dos "antecedentes" ou "precursores" de Freud; além do mais, o encontro com os textos de Morelli ocorreu [...] na fase "pré-analítica" de Freud. Temos que tratar, portanto, como um elemento que contribuiu diretamente para a cristalização da psicanálise (GINZBURG, 2014, p 148).

Não obstante, é dessa relação do gesto analítico representado pela figura de Holmes com as bases dos saberes da psiquiatria que Ginzburg vem afirmar, diante desse exame do olhar proposto sobre os dados marginais de uma obra-prima, que esses

eram reveladores porque constituíam os momentos em que o controle do artista, ligado à tradição cultural, distendia-se para dar lugar a traços puramente individuais, "que lhe escapam sem que ele se dê conta". Ainda mais que a alusão, não excepcional naquela época, a uma atividade inconsciente, impressiona a identificação do núcleo íntimo da individualidade artística com os elementos subtraídos ao controle da consciência (GINZBURG, 2014, p. 150).

Dito isso, vemos delinear-se assim uma analogia entre os métodos de Morelli, Holmes e Freud. Posto noutras palavras, nesses três casos vemos a convergência de "pistas, talvez infinitesimais [que] permitem captar uma realidade profunda, de outra forma inatingível. Pistas: mais precisamente sintomas (no caso de Freud), indícios (no caso de Sherlock Holmes), signos pictóricos (no caso de Morelli)" (GINZBURG, 2014, p. 150). Sobremodo, a tripla analogia empreendia pelo historiador se conjuga no fato de que todos os três eram médicos: Morelli era formado em medicina; Conan Doyle fora médico antes de dedicar-se a literatura e Freud era médico.

Nesse sentido, apreende-se que enquanto Saussure desenvolvia sua teoria da língua e a apadrinhava à Semiologia, simultaneamente, esses três médicos praticavam uma Semiologia muito mais antiga e oriunda de uma tradição médica, desde "Hipócrates" e "Galeano" até "as fisiognomonias que são simultaneamente maneiras de dizer e formas de ver o corpo humano: semiologias da exterioridade, da aparência, do invólucro corpo- 


\section{Eu, Yayoi Kusama, que pintei minha obliteração, minha obsessão e minhas fobias}

ral" (COURTINE, 2013, p. 39-48). Contudo, não é apenas aí que Ginzburg estabelece a arquitetura de sua semiologia histórica. Ele ainda requer para esta o horizonte de nosso patrimônio cognoscitivo.

Aos olhos Ginzburg, nossa habilidade de apreensão de sentidos advém de uma herança ainda mais remota, aperfeiçoada no decorrer de gerações. Isso por considerar que em nossa ancestralidade "o homem foi caçador [...] aprendeu a reconstruir as formas e movimentos das presas invisíveis pelas pegadas de lama, ramos quebrados [...] Aprendeu a [...] interpretar e classificar pistas infinitesimais como fios de barba" (GINZBURG, 2014, p. 151). Desse modo, para o historiador, "Gerações e gerações de caçadores enriqueceram e transmitiram esse patrimônio cognoscitivo." (GINZBURG, 2014, p. 151). Assim, percebendo o mundo através de olhos de caçadores, é que nós poderíamos então também registrar o mundo em seus pormenores, em suas minúcias, sobretudo através do exame do olhar.

Em síntese, posicionado esses saberes primitivos sobre o decifrar e o ler pistas, Ginzburg assevera que o que caracteriza tal saber é "capacidade de, a partir de dados aparentemente negligenciáveis, remontar uma realidade complexa e não experimentável diretamente" (GINZBURG, 2014, p. 152). Dessa maneira, acrescenta-se que essa coleta de dados se dispõe sempre pelo observador de modo tal à construção de uma sequência narrativa a partir dessa experiência da decifração de pistas. Dito de outro modo compreende-se

o fato de que as figuras retóricas sobre as quais ainda hoje funda-se a linguagem da decifração venatória - a parte pelo todo, o efeito pela causa são reconduzíveis ao eixo narrativo da metonímia, com rigorosa exclusão da metáfora, reforçaria essa hipótese - obviamente indemonstrável. [Portanto,] o caçador teria sido o primeiro a "narrar uma história" porque era o único capaz de ler, nas pistas mudas (senão imperceptíveis) deixadas pela presa, uma séria corrente de eventos (GINZBURG, 2014, p. 152).

Assim sendo, ao considerar desde o caçador agachado na lama que escruta as pistas da presa, até Holmes que decifra parentescos consanguíneos entre testemunha e vítima a partir de lóbulos de orelhas, portanto, para Ginzburg pode se falar de um paradigma indiciário ou venatório dirigido 
segundo as formas de saber, para o passado [pelo processo de decifração], o presente ou o futuro [pelo processo da adivinhação]. Para o futuro - e tinha-se a arte divinatória em sentido próprio -; para o passado, o presente e o futuro - tinha-se a semiótica médica na sua dupla face, diagnóstica e prognóstica -; para o passado, tinha-se a jurisprudência (GINZBURG, 2014, p. 154).

Logo, conforme se apreende, existem duas semiologias. Aquela idealizada por Saussure, embasada em sua concepção do signo linguístico que "nos situa no universo desmaterializado e sistêmico do uso consciente dos códigos e dos signos, com seus prolongamentos estruturalistas" (COURTINE, 2014, p. 40). E outra mais remota, aquela apresentada por Ginzburg que se inscreve no terreno da antropologia e que se baseia no

ajustamento de indícios, depositados mais ou menos conscientemente ao longo dos conjuntos significantes; apoiada sobre práticas nas quais o elemento qualificativo, sendo que a parte subjetiva daquele que produz o indício como aquela de quem o detecta não saberiam ser eliminadas, nem mesmo reduzidas; práticas onde o uso da intuição, a espiadela, o "faro", constituem os elementos essenciais (COURTINE, 2014, p. 40).

Isso posto, cabe dizermos que entre essas duas escolhas divergentes de análise e de interpretação das imagens, em nossa perspectiva da Análise de Discurso foucaultiana, para analisarmos os enunciados imagéticos de Yayoi Kusama é a esteirada Semiologia Histórica aquela que nos filiamos. Isso porque, como já o dissemos, partindo da mesma crítica à semiologia das imagens (tal como a encontramos junto a Roland Barthes cuja abordagem destas segue as assemelhando à estrutura sígnica linguística; qual uma réplica ao sentido saussureano do termo) vemos aí os limites epistemológicos da AD se expandirem ao turno de Jean-Jaques Courtine, quando ele introduz nesse campo o caráter discursivo da intericonicidade. O faz, para tanto, a partir dos conceitos foucaultianos de enunciado, arqueologia e genealogia, formulando-a assim como conceito que propõe uma arque-geneaologia das imagens de nossa cultura.

Courtine, portanto, assim considera que uma imagem, tal como "um enunciado tem sempre as margens povoadas de outros enunciados" (FOUCAULT, 2010, p. 110), logo, tão pouco "não existe imagem que não nos faça ressurgir outras imagens, tenham sido elas 


\section{Eu, Yayoi Kusama, que pintei minha obliteração, minha obsessão e minhas fobias}

outrora vistas ou simplesmente imaginadas" (COURTINE, 2013, p. 43). Dito isso, essas imagens apreendidas a partir de seus ícones então se articulam de forma a restituir os seus vínculos umas com as outras partindo do imaginário dos indivíduos que compartilham da mesma cultura, tendo em vista possibilidade disso dada a reverberação das imagens no tecido da memória.

De resto, mostramos nesse capítulo como a persona/corpo de Yayoi Kusama (outrora mulher e estrangeira excluída da cena pop cultural artística norte-americana) veio hoje a coabitar entre os gênios-loucos do inabitável establishment das artes internacionais. Isso, o fazendo a partir de sua autopromoção (o Kusama World), essa decorrida de seu auto-internamento (seu acontecimento, sua estratégia "verdade-arte"), isso, tendo-se aí verificados os métodos (as técnicas de si, forma de resistência) imbricados às relações de poderes-saberes exercidos pela psiquiatria, pelo establishmente pela governamentalidade do si.

Finalmente, nesse passo propomos uma análise do discurso das imagens para verificarmos sob quais máscaras e redes de reminiscências pessoais e de memórias coletivas a atualidade do sujeito "artista-louco" ainda mantém seu rastro histórico admitindo-se construído (ou não) como tal pelos olhos do establishment e da mídia em/através da persona de Kusama. Para darmos andamento com o processo de decifração do sujeito Yayoi Kusama (sujeito que traja a loucura a partir de sua proposta estético-patológica, e não outro) cabe agora, diante das seguintes materialidades enunciativas "Obsessão por sexo e comida" (1966) e "Auto-obliteração de Kusama" (1967), adentrarmos no hall dos gênios-loucos buscando: o corpo discursivo de Yayoi Kusama que aí ocupa hoje a posição "artista-louco" e os sujeitos míticos que aí habitam - pela esteira da Intericonicidade, conforme veremos a seguir. 


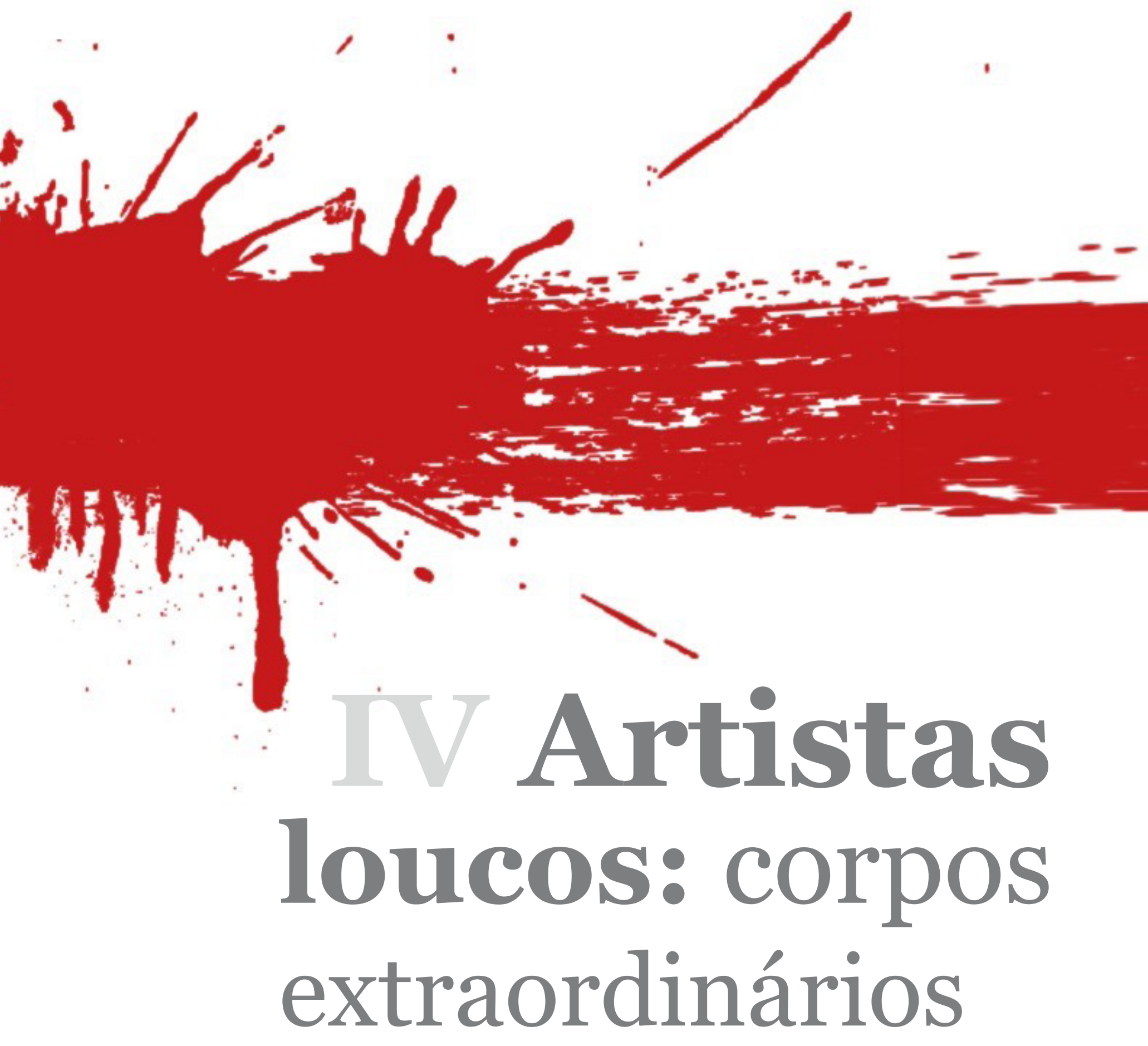


"É a mulher que lança maior sombra ou projeta a mais intensa luz em nossos sonhos".

Charles Baudelaire ${ }^{36}$

Ao considerarmos o copo como objeto de análise, no interior da Análise do Discurso, a partir dos postulados de Michel Foucault e dos estudos de Jean-Jacques Courtine e de Nilton Milanez, isso significa abordar tal invólucro como uma unidade discursiva. Desse modo, excluímos de nosso horizonte analítico o corpo em suas funções biológicas e em exercício de suas práticas corriqueiras sócio-históricas. Não se trata de analisar, portanto, o corpo exposto às práticas diárias e corriqueiras, automotivas ou refletidas, como aquele em prática esportiva, que lê, que dorme, transa ou caminha.

$\mathrm{Na} \mathrm{AD}$, para encontrarmos o corpo discursivo, é preciso antes "focalizar a existência material desse objeto que denominamos corpo, em consonância com suas formas e carnes, por meio da representação sob a qual o identificamos" (MILANEZ, 2009, p. 215). Isso significa, primeiramente, que precisamos considerar esse corpo abordado colocando em evidência a sua existência histórica e seu status material, desse modo, retomando o questionamento arqueológico foucaultiano “quem fala?” (FOUCAULT, 2010, p. 56) no momento em que olhamos para tal invólucro corporal.

De igual forma, é necessário ainda olharmos para o lugar no qual esse corpo se insere e para a data que ele aponta, a fim de estabelecer os limites que fazem com que esse corpo apareça num dado momento, num dado lugar e não em outro. Com isso, esse corpo pode ser compreendido não apenas como uma "simples prática corporal e objetivante, mas como prática discursiva" (MILANEZ, 2009, p. 215) que, consoante à perspectiva foucaultiana, sinaliza a prática discursiva como um

conjunto de regras anônimas, históricas, sempre determinadas no tempo e no espaço, que definiriam, em uma dada época e para uma determinada área social, econômica, geográfica ou linguística, as condições de exercício da função enunciativa (FOUCAULT, 2010, p. 133).

36 Citado na revista La Révolution Surréaliste, volume único, de 1924. Apud BRIONY, Fer. In Surrealismo, Mito e Psicanálise, p. 177. Realismo, Racionalismo, Surrealismo, 1993. 


\section{Eu, Yayoi Kusama, que pintei minha obliteração, minha obsessão e minhas fobias}

Ora, uma vez compreendido esse corpo como unidade discursiva (portanto,como um enunciado), a função enunciativa possibilita que este surja em sua materialidade, por sua vez, fazendo-o emergir em redes, lhe possibilitando descolamentos e modificações. Desse modo, criam-se "novos campos de saber e delineiam certo tipo de sujeito do conhecimento" (MILANEZ, 2009, p. 216). Ainda conforme aponta Milanez, em se observando tais mecanismos que assim constroem o corpo como discurso; e assim destacam a sua existência material; tornam-se primordial considerar

que tipo de conhecimento vai produzir o corpo no discurso? Quais práticas discursivas entrelaçam essa materialidade corpóreo- discursiva? Que artes do existir essa prática corporal discursiva colocaem evidência? Quais materialidades e jogos podem constituir uma identidade no discurso? (2009, p. 216).

Assim posto, é diante do arcabouço foucaultiano exposto e associado ao pensamento de Milanez que principiamos nossa abordagem da persona Yayoi Kusama como corpo - unidade discursiva (a posição-sujeito "artista-louco" que "fala") e emerge historicamente no establishment das artes contemporâneas, primeiramente, por meio da seguinte materialidade: "Auto-obliteração de Kusama37” (MORRIS, 2013, p. 31). O enunciado verbal tomado em questão é título de seu filme hipnótico de 1967 que dá visibilidade ao copo de seu protagonista - a própria artista - enquanto suporte estético num dado momento (a década de 1960), num dado lugar (a cena artística cultural dos Estados Unidos, em Nova York) e não outro. Trata-se de um curta-metragem que "foi realizado no auge do envolvimento da artista com a Nova York radical, um momento coincidente com o pico da fusão cultural dos Estados unidos, mas não desconectado dele" (MORRIS, 2013, p. 31). Obra, a saber, cuja

combinação frenética de arte, natureza e sexo [...] encapsula o espírito inebriante do excesso de drogas, liberação sexual e outras formas de experimentação política, cultural e social que marcou a vanguarda da cultura jovem urbana da década de 1960, em Nova York, [...]. Cinquenta anos depois, aspectos vintage da obra podem suscitar um sorriso, mas o filme ainda perturba e choca: por motivos de decência, sua apresentação mais recente no Whitney Museum de Nova York em junho de 2012, deu-se em tela pequena [...]. O crítico de cinema norte-americano J. Hoberman o descreveu como "arte hippie de primeira grandeza, mais um expoente do momento social do que cinema" (MORRIS, 2013, p. 31). 


\section{Eu, Yayoi Kusama, que pintei minha obliteração, minha obsessão e minhas fobias}

Por sua vez, tendo considerada a reverberação temática espacial-local do curta metragem, no entanto, ao abordá-lo, interessa-nos mais pensar esse corpo junto ao título dessa obra. Isso em razão de ela ser o ponto originário de uma repetição enunciativa (“ $A u$ to-obliteração de Kusama") recorrente ao longo da carreira da artista entre títulos edemais obras suas, essas posteriormente criadas e expostas em galerias como a Tate Modern ou ainda disseminadas pelo Kusama World. Pontuados momento e lugar, que não outros sobre o referido enunciado, prossigamos com a verificação de evidências históricas e certo status material que levaram Yayoi Kusama a ocupar a posição-sujeito "artista-louco" nesse establishment arrolados, por sua vez, à voz do sujeito histórico "artista-louco" que aí fala.

Faz-se necessário nessa etapa, antes de tudo, apontarmos para dois determinados 'falantes' recorrentes na história da arte. Tal como já o dissemos anteriormente, sabe-se que a história da arte é construída pelo ressoar de ecos de poderes e saberes, de um lado, advindos pela pulsão de vozes dos próprios artistas pretéritos e contemporâneos, do outro, pela pulsão de vozes de antigos mecenas, bem como de seus atuais curadores. Também como já o pontuamos, o que se implica nessa relação - artista e curador - é uma evidente relação de poder, isso pela história da arte se tratar de um circuito de uma ordem discursiva (o establishment), no qual, logo, se incidem poderes/saberes que são gerenciados por sujeitos estatuários, autoridades de uma "verdade" (quer o seja demonstrada e/ou estratégica) que determinam, portanto, a qualidade, o valor de 'arte'(a tal "verdade-arte"), bem como seu porta-voz, o sujeito 'artista'.

Junto a isso, ainda há de se considerar, no sentido que estabelecemos, que só depois de apreendidas as vozes dos mecenas/curadores é que somos apresentados à voz, à figura/ gênio do artista, essa transformada/considerada/autorizada na qualidade de um "monumento" (FOUCAULT, 2010, p. 157); uma obra-prima. Isso, se tendo em vista as figuras do artista e do curador alocados como sujeitos num cenário em que "não se temo direito de dizer tudo, nem se pode falar de tudo em qualquer circunstância" (FOUCAULT, 2009, p. 9). Ora, hoje, se reconhecemos os dois grandes faróis do Renascimento, Miguel Ângelo Buonarroti (1475-1564) e Leonardo Da Vinci (1452-1519), é porque foram ambos 


\section{Eu, Yayoi Kusama, que pintei minha obliteração, minha obsessão e minhas fobias}

reconhecidos/autorizados antes, na forma/função de artistas para/no establishment, ambos pelo notório estadista italiano Lorenço de Medici ${ }^{38}$ (1449-1492).

Não tão distante, relembramos que a coroação da carreira de Yayoi Kusama se dá a partir de seu estreitamento de relações com Frances Morris, curadora chefe da Tate Modern somente após sua auto-internação no hospital psiquiátrio, bem como sua patologia-estética foi admitida como tal no establishment segundo a "autorização" do curador Larratt-Smitt. Ou seja, sendo os curadores que reclamam na/para a história da arte os artistas e sua "verdade-arte" a partir de sua "verdade-demonstrada", na ordem discursiva do establishement tal figura/gênio do artista só surge aí também autorizada como tal. Não obstante, observa-se que, não tão raro, entre os sujeitos pintores que falam (autorizados) para/no establishment, encontra-se uma forma, uma posição-sujeito continuamente ligada à persona do louco: eis que falamos do artista "excêntrico"; ou ainda, do "artista-louco".

Vislumbrando um breve percurso histórico dessa perspectiva genealógica sobre o relacionamento da loucura com a arte, apreendemos ligados às esteiras da "verdadearte" e do "artista-louco" vários ícones (ora em temática/estética, ora em protagonismo do sujeito objetivado/subjetivado) que abordaram, cada um ao seu turno essa patologia. Principiam aí os surrealistas primevos Hieronymus Bosch (1450-1516) e Giuseppe Arcimboldo (1527-1593). Também perscrutando a loucura encontramos o simbolismo delirante de William Blake (1757-1827) e as sátiras grotescas de James Ensor (1860-1940). Ao lado do pai da pintura metafísica, Giorgio de Chirico (1888-1978) encontra- se Marcel Duchamp (1887-1968), o percurssor do ready made que impulsionou a escola surrealista dos anos 1920 cujo maior expoente é o $1^{\circ}$ marquês de Dalí i Domènech de Púbol, pintor catalão mais conhecido como Salvador Dalí (1904-1989).

Conforme se depreende entre tantos sujeitos e estéticas peculiares que deram voz à(s) loucura(s) na história das artes, é possível pontuarmos que a "verdade" de uma obra de arte segue intrinsecamente ligada à relação de poder que se estabelece entre as condições sócio-históricas dadas entre um determinado tempo, curador e artista. Igualmente

38 Mais conhecido como Lourenço, o Magnífico (Lorenzo Il Magnifico), trata-se de um estadista italiano,soberano da República Florentina. Patrono de acadêmicos, artistas e poetas, sua vida coincidiu com efervescência cultural do início do Renascimento italiano e sua morte marcou o fim da chamada Idade de Ouro de Florença. Consultado em Lorenzo de' Medici, Encyclopcedia Britannica, Inc., em 09 junho 2016.Disponível em: https://www.britannica.com/biography/Lorenzo-de-Medici 


\section{Eu, Yayoi Kusama, que pintei minha obliteração, minha obsessão e minhas fobias}

não são raros os casos de "resgates artísticos" no establishment quando dessa relação de poderes-saberes apreende-se que o sujeito artista não foi reconhecido/admitido pela voz do sujeito curador num determinado tempo, no caso, vindo só a ser reconhecido posteriormente pela voz de outro curador.

Comprova isso o holandês Vincent Van Gogh (1853-1890), célebre pintor também entre os visionários da loucura cuja "verdade-arte" - acontecimento (essa apenas admitida como tal tardiamente) inscrita na arte que produziu foi completamente incompatível com a "verdade" - demonstrada - estabelecida pelo establishment de seu tempo, o qual jamais o reconheceu enquanto pintor durante sua vida (durante o período pós-impressionista). Dito isso, demonstrada a recorrência com que a loucura é reclamada pelo establishment vista a relação de dependência/independência pressuposta entre o curador e o artista, pontuamos assim que o "artista-louco" tem neste seu lugar (uma posição-sujeito), sua existência histórica (enquanto unidade discursiva), e consequentemente apresenta aí, por derradeiro, certo status material (seus enunciados "obras-primas").

Desse modo, ao nos aproximarmos mais da figura do sujeito histórico artista-louco que delineamos a partir desse establishment, torna-se oportuno não perdemos de vista em nossa análise a noção de repetição como condição de possibilidade na AD. Referimo-nos à repetição dos discursos de um conjunto de marcas formais, quer o seja no campo verbal ou imagético. Ou seja, primeiro, relembramos que um texto primeiro traz sempre a presença de um texto segundo, e, por conseguinte, também o é imagético; pois no discurso o enunciado não é "nem inteiramente linguístico, nem exclusivamente material" (FOUCAULT, 2010, p. 97). Em outras palavras, especificamente à luz arqueológica dos conceitos foucaultianos, "um enunciado tem sempre as margens povoadas de outros enunciados" (FOUCAULT, 2010, p. 110), quer o seja da ordem linguística ou da ordem da imagem, portanto.

A nuance sobre a figura do artista-louco que nos interessa aqui é aquela que surge como uma forma em repetição nas modalidades de existência do discurso via enunciados, ora de natureza linguística, ora de natureza fotográfica/pictórica. Com isso, a forma, essa unidade discursiva "artista-louco" vista sob a lente foucaultiana nos modos de um tipo de organização, isto é, de “diversas formas de sucessão e, entre elas, as diversas disposições 


\section{Eu, Yayoi Kusama, que pintei minha obliteração, minha obsessão e minhas fobias}

das séries enunciativas" (FOUCAULT, 2010, p. 63), desse modo nos permite observar a formação de um conceito encadeado (o artista louco) a uma série que se liga estritamente a modos de repetição (o establishment da história da arte) nas reverberações do enunciado (títulos de obras, plataformas midiáticas/obras- primas).

Perfilados os conceitos de unidade discursiva, enunciado e a repetição dos discursos ligada aos rastros de uma existência histórica, à posição-sujeito, escavemos neste passo as margens do referido enunciado obra-prima "Auto-obliteração de Kusama" a fim de evidenciarmos a organização das diversas formas de sucessão da série enunciativa "artista-louco" que se repetem na história da arte até a atualidade em Yayoi Kusama. Iniciamos a análise escandindo semanticamente o enunciado proposto a partir do elemento composicional auto, do substantivo obliteração e do nome próprio feminino Kusama, a fim de sondarmos possíveis reverberações similares nos ecos que ressoam nas margens destes, por sua vez dispersos na história da arte.

O primeiro fragmento recortado do enunciado referido tem sua origem na palavra grega autós e diz respeito à expressão da "noção de si próprio, por si mesmo"39. O seguinte substantivo, oriundo do verbo latino oblittero (apagar, fazer esquecer, abolir) abraça como verbo transitivo e pronominal (obliterar) os seguintes significados: $1^{\mathrm{o}}$, Ato ou efeito de obliterar; $2^{\circ}$, [Anatomia] Estado de um duto ou canal obstruído; $3^{\circ}$, Fazer desaparecer ou desaparecer uma coisa, pouco a pouco, até que dela não fique nenhum vestígio; $4^{\circ}$, Fechar(-se) uma cavidade. $=$ OBSTRUIR, TAPAR; $5^{\circ}$, Fazer esquecer ou cair no esquecimento. ${ }^{40}$

Uma vez ilustrado os significados atrelados às palavras auto e obliteração, faz-se necessário rastrear, no campo da história da arte, uma produção de sentidos de similares significações noutras margens enunciativas. Ou seja: buscamos aí pela sugestão temática de uma expressão de si próprio, por sua vez enredada numa atitude consciente que evoca num gesto anatômico/psicológico a simultaneidade do fazer desaparecer uma coisa

39 Pesquisado em Dicionário Priberam da LínguaPortuguesa [em linha], 2008-2013, https://www.priberam.pt/dlpo/auto [consultado em 06-05-2017].

40 Pesquisado em Dicionário Priberam da LínguaPortuguesa [em linha], 2008-2013, https://www.priberam.pt/dlpo/oblitera [consultado em 06-05-2017]. 


\section{Eu, Yayoi Kusama, que pintei minha obliteração, minha obsessão e minhas fobias}

à ação de fechar(-se) uma cavidade, obstruir, tapar. No mais, em considerando a verve estético-erótica da obra de Kusama, é justamente a conotação sexual que lemos e buscamos aqui para o substantivo cavidade e para os verbos obstruir e tapar. Com isso, fazemos alusão, respectivamente, à possíveis materialidades significantes atreladas ao órgão sexual feminino e à própria prática do ato sexual em si.

Já sobre o nome próprio Kusama, o consideramos a partir da significação superficial da palavra, ou seja, à simples designação ao gênero feminino lida assim no Ocidente (e não pelo significado de sua raiz oriental, tão somente). Prosseguindo, por conseguinte, ao pensamos nesse sujeito Kusama - mulher - que alega ficar"aterrorizada só ao pensar que algo longo e feio como um falo [1he] penetre" (KUSAMA, 2002, p. 47), acabamos relacionando o nome/palavra Kusama à outra palavra deveras recorrente na história da arte: eis a palavra virgem.

Porém, não abraçamos essa palavra associando-a as madonas renascentistas, barrocas ou clássicas. Essas não efetivam, enquanto enunciados continuamente reverberados na história da arte, os sentidos sexuais pensados aqui para auto, cavidade, tapar e obliterar que propomos anteriormente ligados à sugestão temática de uma expressão de si próprio, por sua vez enredada numa atitude consciente que evoca num gesto anatômico/ psicológico a simultaneidade do fazer desaparecer uma coisa à ação de fechar(-se) uma cavidade, obstruir, tapar.

Encontramo-los, porém, num similar conjunto de marcas formais associado a uma singular virgem surrealista. É desse modo que emparelhamos o enunciado "Auto- obliteração de Kusama" (título de seu premiado filme) ao seguinte: "Jovem Virgem Auto-Sodomizada pela sua Própria Castidade", em seu turno, título de uma icônica pintura de Salvador Dalí, de 1954. Vejamos a referida tela abaixo: 


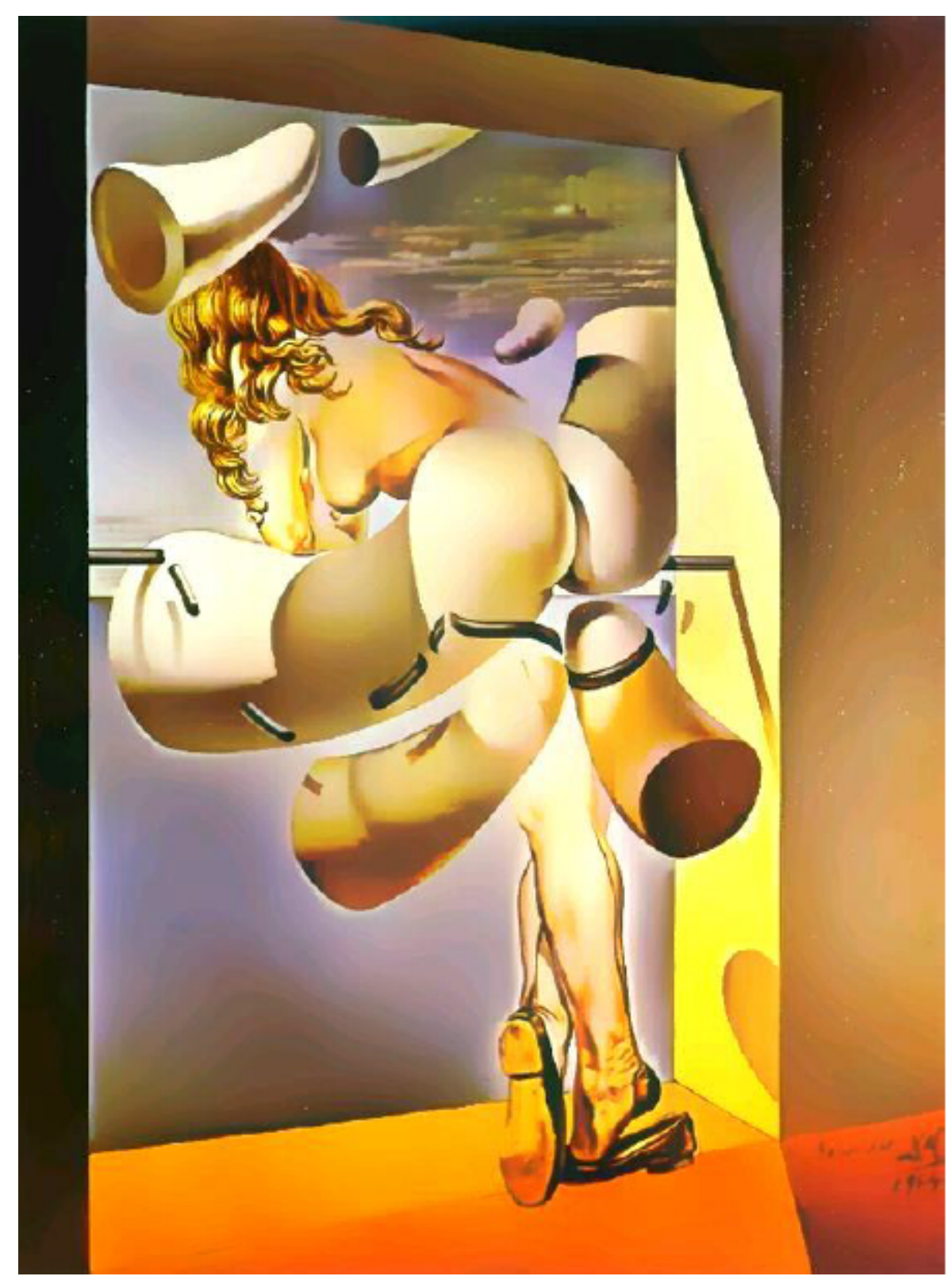

Figura 7 - Jovem Virgem Auto-Sodomizada pela sua Própria Castidade. Savador Dalí, 1954.

Fonte: BECKETT, 1997, p. 364.

A respeito de sua temática/estética, nesta obra se observa confortavelmente debruçada de costas sobre uma janela a formação de um corpo feminino seminu, calçando sapatilhas, usando apenas meias-collant. Corpo esse composto por falos de diversos tamanhos, coroado por uma cabeleira loura que, compenetrada, mira reflexiva para o horizonte. Tal conjunto de elementos faz vir à tona, assim como já designa o título da obra, um campo do discurso sexual e de dominação - similar ao título e proposta estético-patológica de Kusama: uma virgem arrolada à prática física/psíquica sexual, prática essa de própria vontade, por assim dizer. 


\section{Eu, Yayoi Kusama, que pintei minha obliteração, minha obsessão e minhas fobias}

Ao relacionarmos a temática/estética imagética ao enunciado não-verbal Jovem Virgem Auto-Sodomizada pela sua Própria Castidade assim apreendemos à posição de um corpo feminino ao qual é atribuído um efeito sexualizante. Isto por, em seu primeiro plano, encontrarem-se as glandes de dois imensos falos sugerindo a composição pictórica de suas nádegas, expostas totalmente nuas. Por fim, tal gesto pode vir a ser compreendido como um oferecimento fadado à passividade da prática sexual em razão de outro falo pairando ali próximo e dada à falta de resistência - ou talvez disposição - da jovem. Eis, portanto, a atitude sodomita da virgem assim retratada por Dalí.

Contextualizada a temática estética da pintura, ater-nos-emos, neste momento, apenas à estrutura linguística desse enunciado. No campo da história da arte, uma vez encontradas as margens do enunciado de Yayoi Kusama povoadas pelas margens de outro enunciado, aquele de Salvador Dalí, sobremodo, percebemos ambos ligados pela similitude que se atrelada à presença dessa unidade discursiva, o corpo. Insistimos aí, conforme estatui o postulado foucaultiano pela leitura de Courtine e Milanez, a existência material desse objeto corpo discursivo em consonância com suas formas e carnes por meio de uma representação sobre a qual o identificamos - àquele de duas virgens. Colocamos, para tanto, em evidência, as existências materiais "Auto- obliteração de Kusama" e "Jovem Virgem Auto-Sodomizada pela sua Própria Castidade" arroladas aos seus respectivos status materiais; lidos aqui: "obras de arte" a partir do momento em que olhamos para tais corpos discursivos (na ocasião dos establishments: em 1957 na estética surrealista, e 1967 na esteira contemporânea) através das vozes dos falantes "artistas-loucos" Yayoi Kusama e Salvador Dalí.

Por sua vez, averiguando essas unidades discursivas surgindo cada uma em sua própria materialidade, percebemos o corpo discursivizado pela persona de Kusama (astista que, tal uma virgem temerosa, neurotiza-se pela ideia de ser penetrada por falos) deslizando para o corpo discursivizado da virgem de Salvador Dalí (composição onírico-surrealista de uma virgem submissa à passividade sexual por vontade própria, por sua vez rodeada/composta por falos). Assim verificamos uma função enunciativa em que se criam novos campos de saber delineando certo sujeito do conhecimento - os sujeitos “artistas-loucos” Kusama, nas artes modernas, e Dalí no Surrealismo. 


\section{Eu, Yayoi Kusama, que pintei minha obliteração, minha obsessão e minhas fobias}

De resto, observados tais mecanismos que dessa forma tanto constroem o corpo como discurso como destacam sua existência material, enfim pontuamos: $1^{\text {o }}$; a produção de um conhecimento estético-artístico a partir da unidade corporal que assim incide no discurso das artes. $2^{\circ}$; o entrelaçamento das materialidades corpóreo-discursivas de“ $A u$ to-obliteração de Kusama" (1967) e "Jovem Virgem Auto-Sodomizada pela sua Própria Castidade" (1954) a partir de suas práticas discursivas: conjunto de regras anônimas e históricas (estabelecidas no establishment das artes) determinadas por tempo e espaço distintos (a considerar as escolas contemporânea e surrealista) assim definindo as condições de exercício das funções enunciativas em jogo por Kusama e Dalí (lidas aqui como “obras-primas"); 3․ A evidência da sexualidade e da dominação colocadas por ambas essas práticas corporais discursivas. Por fim, $4^{\text {o }}$; Dessas materialidades e jogos acenados tem-se constituída também a identidade "artista-louco" no discurso das artes.

Exposta a análise linguística dos enunciados "Auto-obliteração de Kusama"(1967) e "Jovem Virgem Auto-Sodomizada pela sua Própria Castidade" (1954) propomos agora um segundo gesto analítico emparelhando a foto-arte "Obsessão por sexo e comida (1966) de Kusama (figura 8) à pintura “Jovem Virgem Auto-Sodomizada pela sua Própria Castidade" (figura 7). Ao pensarmos numa escansão de suas materialidades pictóricas significantes é que aproximamos à esteira da Análise do Discurso, para tanto, o paradigma indiciário de Ginzburg e a Intericonicidade de Courtine.

\section{Do Surrealismo à Psiquiatria - entre os fantasmas fálicos de Freud e Salvador Dalí}

André Breton

41 Apud FER, 1993, p. 171. Breton citado em R. Parker e G. Pollock. Old Mistresses, p. 138. 


\section{Eu, Yayoi Kusama, que pintei minha obliteração, minha obsessão e minhas fobias}

Pontuados os poderes-saberes que imbricam a loucura com a história da arte, tendo evocado nesta pesquisa a Jovem Virgem Auto-sodomizada pela sua Própria Castidade, neste passo, em busca se uma leitura de sua materialidade pictórica significante, mostra-se necessária, antes, uma palavra arquegenealógica sobre a relação dos saberes (surrealistas e psiquiátricos) que pretendem a forja estética dessa patologia em tal meio. Para tanto, diante dessa peculiar escola de estéticas pluralizadas, nos atemos em especial sobre o surrealismo dos anos 1920, à sua temática maior - o feminino -, e seu maior expoente, Salvador Dalí. Em linhas gerais, primeiramente sobre essa escola, segundo salienta a historiadora de arte de curadora Briony Fer (1956-), por sua vez,

desde o início, o surrealismo era um movimento heterogêneo. Incluía escritores, pintores, poetas e fotógrafos; mais tarde, no final dos anos 20, diversificou-se na produção de objetos e filmes. Além disso, os surrealistas produziram uma grande quantidade de revistas, utilizando-as como plataformas para debate. Mesmo se nos restringirmos à pintura surrealista, concluiremos que nunca houve uma unidade de estilo (FER, 1993, p. 171).

Nesse sentido, sobremodo se apreende que "os surrealistas jamais recomendaram que se atribuísse maior valor à arte abstrata, ou à figurativa" (FER, 1993, p. 171-172). Com isso, dessa esteira estética em particular do hall das grandes escolas da história da arte, as pinturas surrealistas eram muito diferentes em termos formais, tal como pode perceber ao observar Pintura (1927, vide anexo, figura 28, p. 146) de Juan Miró (1893-1983) e As acomodações de desejos (1929, vide anexo, figura 29, p. 156) de Salvador Dalí, por exemplo. Consequentemente, a produção surrealista pode ser considerada - a partir de sua diversidade e diferenças de ideias - como um "campo de representação em constante mudança, que usa frequentemente a diferença para gerar significados” (FER, 1993, p. 171). Para a historiadora, sobremodo nessa prática, pensando as maneiras como a diferença (estética) se expressava no surrealismo, pulsava assim aí a "metáfora do "feminino" [essa], metáfora central promotora da diferença" (FER, 1993, p. 171) no cerne dessa escola.

Discutindo esse aspecto da diferença sexual adotada pelo surrealismo, sabe-se que a preocupação surrealista com a sexualidade trazia à discussão, segundo os saberes do establishment, aquilo o que fora reprimido pela tendência "construtiva" (FER, 1993, p. 180), bem como tal a associação e sugestão "eram positivamente cortejadas no imaginário surrealista, o que podia também questionar a aparente pureza da forma "funcional" ou ma- 


\section{Eu, Yayoi Kusama, que pintei minha obliteração, minha obsessão e minhas fobias}

terial tão cara aos puristas" (FER, 1993, p. 180). É assim que vemos aprática surrealista, em suas mais diversas formas (poesia, pintura, objetos, fotografias, filmes) preocupar-se, em termos estéticos, com "uma mitologia do moderno" (FER, 1993, p. 180) a qual chamava para si o

caráter mítico de outros tipos de representação, especialmente aqueles que reivindicavam um forte laço com a "realidade". E a mitologia que o surrealismo constituiu para si centrava-se na "mulher" como o "outro", como estando mais próxima do inconsciente que os homens, e tentava habitar o mundo da "alteridade", do inconsciente, indo além de suas fronteiras, com o intuito de questionar o que via como um mundo moralmente falido. Isso significa enxergar além das simples aparências e entender que, sob estas, jaz uma série de forças psíquicas e sociais sobre as quais os indivíduos têm pouco ou nenhum controle (FER, 1993, p. 180).

Isto é, ao olharmos para a perspectiva do "feminino" - essa analogia erótica -, empregada como expressão da ordenação temático/estética surrealista (isso tanto nas obras produzidas por homens como pelas mulheres artistas desse período filiados a essa escola), segundo Briony Fer há de se admitir na poética surrealista a existência de traços da influência teórica da psiquiatria de Sigmund Freud (1856-1939). Ela assim o considera por, diante dessa analogia, as obras surrealistas revelarem, de um lado, que "o aspecto sexual da modernidade era crucial para os surrealistas", e do outro, uma vez admitida à extensão do pensamento freudiano no seio da escola surrealista, no entanto se faz necessário também distinguir nessas obras as preocupações surrealistas entre “o Freud "deles" e o Freud da teoria psicanalítica mais recente" (FER, 1993, p. 171).

Noutras palavras, embora seja considerado vital o impulso histórico do pensamento freudiano e da psicanálise para o desenvolvimento do universo surrealista, haja visto a utilização de vários temas freudianos pelos artistas desse movimento, nota-se também certo "sentimento de revolta" por parte destes a respeito dessa relação. Isso porque, "Freud oferecia um modelo explicativo para revelar o que era reprimido, para explorar o conteúdo "latente" mais do que o "manifesto" de sua época (para usar os termos de Freud sobre a análise dos sonhos) (FER, 1993, p. 182)”. Em termos práticos, isso implicava olhar para o "“subterrâneo" da modernidade, focalizando a sexualidade,o desejo e as ambigüidades da diferença sexual" (FER, 1993, p. 182). 


\section{Eu, Yayoi Kusama, que pintei minha obliteração, minha obsessão e minhas fobias}

O embate em questão gira em torno do pensamento proposto pelos surrealistas - o "sentido poético dos mecanismos envolvidos no processo do sonho" (sua "verdade-arte") - e da execução deste, os gestos, as práticas propriamente ditas do artista surrealista - chamada "psico-automotismo no seu estado puro" (a posição adotada pelo sujeito "artista-surrealista" diante da arte). Seria por meio desse sentido e gestos os quais, segundo reclamados pelo Manifesto Surrealista (1924) de André Breton (1896-1966), as obras que se pretendiam surrealistas deveriam ter seu ponto de partida expresso "por meio da palavra, ou por outro meio qualquer" (FER, 1993, p. 172). A ideia concebida por Breton para a estética surrealista que se estabelece, enquanto princípio e prática, desse modo condiz com

um "estado de completa perturbação mental" [onde] o uso de uma linha traçada a mão-livre, a conotação de rabisco mesmo, definem uma abordagem totalmente contrária a precisão técnica e às linhas traçadas à régua [e] "nesta embriagante competição, as imagens aparecem como únicos guias da mente", tornando os desejosexplícitos (FER, 1993, p. 173-174).

Contudo, em sendo Freud quem havia dito que "o sonho, como um todo, é o substituto distorcido de alguma outra coisa, algo inconsciente [...], e a tarefa de interpretar um sonho é descobrir esse material inconsciente" ${ }^{42}$, logo, os processos que Freud identifica para "operar" os sonhos - em seu conteúdo manifesto ou latente - coincidem/ou equivalem-se fulcrais à abordagem da arte segundo o princípio e prática surrealista. Isso porque, o princípio da abordagem do inconsciente segundo a psiquiatria freudiana assevera sobre esse que o

manifesto é o que aparece, o latente é o inconsciente expressando o que a mente não quer mostrar. A "condensação" é o processo pelo qual o conteúdo latente é condensado ou comprimido dentro do mesmo manifesto. Isso pode ocorrer, por exemplo, em tipos de estruturas compostas encontradas em sonhos nos quais diversas pessoas, coisas ou acontecimentos são substituídos por um único elemento. O "deslocamento" é o processo pelo qual o foco do sonho é transferido de um elemento importante para um aparentemente insignificante por meio da censura. Os sonhos libertavam o inconsciente de um modo impossível no estado de vigília - como faziam os fenômenos relacionados, tais como sonhar acordado, atos falhos e lapsos de memória (FER, 1993, p. 181).

42 Apud Fer, in Surrealismo, mito e Psicanálise. FREUD, Introductory Lectures on Psychoanalysis, 1973,p. 144). 


\section{Eu, Yayoi Kusama, que pintei minha obliteração, minha obsessão e minhas fobias}

Sobre essa concomitância (surrealista e freudiana) quanto ao exercício de abordagem do inconsciente é que Breton, no Manifesto Surrealista, aproxima o interesse dos surrealistas à prática do relato dos sonhos experimentada pelos membros do grupo. Prática, no turno surrealista, chamada por Breton de "arbitrariedade no mais alto grau" ${ }^{43}$. Com isso, a fim de compreender os mecanismos do inconsciente, os surrealistas exploravam a linguagem e os processos de funcionamento do sonho olhando

para dentro de si mesmos em busca do que era infantil, mas também exploraram os lapsos de memória, as repressões de toda uma cultura, voltaram-se para o passado, ou para os mitos ancestrais, com o intuito de questionar o presente e imaginar uma saída para as condições atuais - como um meio de transgredir as fronteiras estabelecidas da representação [estética] (FER, 1993, p. 182).

Como se estabelece o modo como essas representações estéticas associadas às questões da sexualidade, à analogia erótica do feminino pela abordagem do surrealismo não se dariam sem a ajuda da teoria da psicanálise em si. No entanto, embora esta seja fundamental à estética surrealista, já sobre as incongruências da perspectiva de Freud na abordagem do âmbito da teoria da sexualidade, segundo os surrealistas, essas giram em torno de o "trabalho de Freud [ser] visto às vezes como extremamente contrário às mulheres, como "falocêntrico", excluindo o feminino exceto enquanto subordinado ao masculino" (FER, 1993, p. 182). Tão pouco, para eles, ainda que se buscasse posteriormente pela interpretação da analogia erótica pela óptica do feminino em Jacques Lacan (1901-1981), vale dizer ainda que os surrealistas consideravam importante não perder de vista o desentendimento das teorias da sexualidade (freudianas ou lacanianas) no que diz respeito às "falhas" destas em explicar como "certos padrões de comportamento, certas normas e atitudes, são internalizadas pelos seres humanos" (FER, 1993, p. 182).

Ou seja, apesar de fundamentais à construção do princípio e prática da abordagem surrealista, as teorias da sexualidade se limitavam em determinar como os papéis atribuídos aos gêneros eram socialmente delineados. Em razão disso, para os surrealistas, elas "não explicariam como as diferenças sociais são reproduzidas interna e inconscientemente na vida psíquica" (FER, 1993, p. 182). Logo, lançando luz no terrenosimbólico

43 Apud Fer, in Surrealismo, mito e Psicanálise. BRETON, Manifesto of Surrealim, 1924, p. 38). 


\section{Eu, Yayoi Kusama, que pintei minha obliteração, minha obsessão e minhas fobias}

desse embate em que o Surrealismo se lançava, tanto em seu aspecto social como psíquico, enquanto, em seu turno, Freud ao pensar a psicanálise como uma nova ciência, assim incentivou a

ideia de que existem diferenças entre homens e mulheres [...] consideradas como produzidas pela cultura, e não pela natureza, determinadas biologicamente [e que é] no desenvolvimento das relações simbólicas dentro da família que essas identidades sexuais são construídas (FER, 1993, p. 182183).

Por sua vez, cumpre daí observarmos, diante da proposta da psicanálise em Freud, que, por outro lado, "os surrealistas claramente não estavam interessados nas suas ideias enquanto princípios científicos [os saberes da psiquiatria]" (FER, 1993, p, 183). Ao contrário, eles buscavam com sua "verdade-arte" (os seus saberes estéticos) enfatizar "as forças metafóricas de alguns dos dramas e motivos psíquicos descritos ${ }^{44}$ pro Freud" (FER, 1993, p. 183). Nesse sentido, haja vista, por exemplo, o conceito freudiano do estranhamento, ou dépaysement, como foi chamado por Breton, que

constituiu uma função crucial do Surrealismo. Pelo menos em parte, ele estava associado à indeterminação das imagens, tanto no tipo de narrativa onírica que Breton viu no trabalho de Chirico como por meiodas técnicas automatistas usadas por outros como Masson e Miró (FER, 1993, p. 193).

Função essa como inúmeras outras que acabaram alimentando a(s) estética(s) surrealista(s), e de "serem elas próprias um tipo de construção mitológica, mas que pretende[m] possuir alguma força explicativa" (FER, 1993, p. 183). Pontuada a relação de saberes da psicanálise freudiana com os saberes surrealistas, para prosseguirmos, trazemos agora à baila de nossa análise uma palavra sobre a figura e obra de Salvador Dalí.

É em janeiro de 1937, na revista The Art Digest, que Dalí é apresentado ao público norte-americano como "o principal expoente da frívola corrente do multiforme surrealismo" (PUPPO, 2011, p. 10). Na ocasião, era um paradoxo para o establishment americano assistir ao "enorme sucesso, mundano e mercantil ao mesmo tempo, de um pintor de origem espanhola" que, ao "apropriar-se da técnica realista holandesa e inspirado pelas ideias de um grupo de escritores franceses", a saber, Breton, Baudelaire e Bataille,

$44 \quad$ Grifo nosso. 


\section{Eu, Yayoi Kusama, que pintei minha obliteração, minha obsessão e minhas fobias}

"estava pintando como nenhum outro as histórias de um médico de Viena [Freud]" (PUPPO, 2011, p. 10).

Filho de uma família abastada, tendo no pai hostilidade à sua inclinação artística, passou a identificá-lo como inimigo e idolatrar a mãe. Disso, apreende-se que os "traços essenciais de sua personalidade nasceram do entrelaçamento patológico e jamais foram aplacados dessas tensões familiares" (PUPPO, 2011, p. 10). Não obstante, os anos de formação de Dalí "confirmam sua tendência à "exceção"; ele era jovem demais à época da vanguarda européia pré-guerra e era deslocado demais pra conseguir compartilhar o longo e conflituoso processo de reelaboração no pós-guerra" (PUPPO, 2011, p. 10).

Em poucos anos, entre 1924 e 1926, Dalí atinge o domínio pleno dos meios pictóricos. Em 1925 fez sua primeira exposição individual numa importante galeria de tendência modernista em Barcelona, cidade que voltou depois de ter sido expulso da Academia espanhola de belas artes. Além de suas exposições e da sua produção de trabalhos, o desenvolvimento de sua estética pictórica "permanecia inseparável da biografia", apresentando "impulsos afetivos, angústias e temores [que] se traduziam em um mecanismo visual de complicadas analogias" (PUPPO, 2011, p. 13). Assim, as tensões do pintor culminam desde as temáticas da "masturbação à obsessão coprofílica [surgidas] na psique atormentada do rapaz, controverso e sensível" até mesmo à expressão obsessiva de sua paixão pelo poeta Federico Garcia Lorca (1898-1936); "sentimento [esse] que o pintor, aterrorizado a cada contato físico, reagia com crescente mal-estar (PUPPO, 2011, p. 13).

Já quanto à colaboração da interpretação psicanalítica de Freud sobre o sonho e sobre as identidades sexuais com a poética surrealista da analogia do feminino, por sua vez, o eco desse encontro teórico-estético chega à Madri quando o Jovem Dalí ainda procurava se impor como pintor. Todavia, Dalí foi inicialmente contra a fórmula com a qual Breton quis resumir o Surrealismo. Precisamente, para Breton o Surrealismo deveria incorrer de um

automatismo psíquico puro, pelo qual propõe-se exprimir, seja verbalmente, seja de quaisquer outras maneiras, o funcionamento real do pensamento. [Esse] ditado do pensamento, na ausência de todos os controles exercidos pela razão e sem nenhuma preocupação estéticaou moral [que] postulava 


\section{Eu, Yayoi Kusama, que pintei minha obliteração, minha obsessão e minhas fobias}

uma expressividade livre dos condicionantes da lógica, da realidade e do controle pelas linguagens codificadas [, logo, para esse automatismo,] o resultado era duplo: uma expressão artística livre de tal forma do controle da razão que escapava das noções de beleza da verdade (PUPPO, 2011, p. 15).

Embora, para Breton, através do automatismo puro se "aumentava o anseio de instituir o processo contra o comportamento realista" e com esse processo se "intensificava o senso do maravilhoso e do fantástico gerado pela mistura entre sonho e realidade, em uma espécie de realidade absoluta, de surrealidade" (PUPPO, 2011, p.15), o verdadeiro problema, na "verdade-arte" dos pintores, era outro. Sendo evidente que, por trás do discurso do automatismo psíquico, operava a prática da escrita automática, justamente aí o automatismo de Breton mantinha "o vício de origem de sero fruto do trabalho dos escritores" (PUPPO, 2011, p. 16).

Consciente que "o olho existe em estado selvagem" e diante da inefabilidade do automatismo psíquico puro com as condições materiais da pintura, ou seja, da linguagem feita de tela e pincéis, desenho e cores, formas e figuras corpóreas e tangíveis, Breton propõe uma articulação estética genealógica, bastante influente no establishment, no artigo $O$ surrealismo e a Pintura, publicado no quarto volume da revista La Révolution Surréaliste (1927). Dessa forma, Breton então convoca à luz de sua causa a "redefinição do cubismo (André Masson, Joan Miró), a herança do assemblage incoerente e orgânico do dada (Jean Arp), a pintura metafísica (De Chirico),a manipulação cinética (Duchamp) e o material da imagem (Marx Ernst)" (PUPPO, 2011, p. 17) indicando, assim, que ainda havia motivos suficientes para "provar e argumentar a utilidade da causa [o automatismo psíquico puro] pela pintura" (PUPPO, 2011, p. 17).

E quanto a Salvador Dalí diante de tudo isso? O pintor catalão, simplesmente, decidiu tomar distancia desse surrealismo, regido pela fórmula de Breton. Em uma "apaixonada carta à Garcia Lorca", Dalí "se opôs sem reservas ao folclorismo lírico e retro [...]. Explicou ao poeta o desejo de encontrar no surrealismo um meio de evasão -a ser compreendido como clareza real” (PUPPO, 2011, p. 18), tão meramente. Logo, passa a estudar "a herança do modernismo europeu. Nesse período ele se confrontou com a espacialidade do cubismo, a nitidez arquitetônica do purismo, a estrutura arquitetônica rigorosa da metafísica" (PUPPO, 2011, p. 18); e só então em 1929 é que Dali juntou-se ao movimento 


\section{Eu, Yayoi Kusama, que pintei minha obliteração, minha obsessão e minhas fobias}

surrealista, à sua maneira. E, sobre a antologia crítica deste "artista-excêntrico", notadamente apreende-se nada menos que o parecer do próprio Sigmund Freud:

até agora tinha a tendência de considerar os surrealistas, que ao queme parece elegeram-me seu santo protetor, palhaços (digamos ao menos $95 \%$, como para o álcool). O jovem espanhol, com seu olhar sincero e fanático e sua inegável maestria técnica, induziu-me a toda outra avaliação. Na realidade, seria muito interessante estudaranaliticamente a gênese de uma pintura muito similar. Do ponto de vista crítico, poder-se-ia sempre dizer que o conceito de arte foge de um aprofundamento quando a relação quantitativa entre material inconsciente e elaboração pré-consciente não respeita certo limite. De qualquer modo, ele tem sérios problemas psicológicos (Apud PUPPO, 2011, p. 149-145).

Dito tudo isso, no tocante à estética-patológica daliesca, apreende-se recorrente a tentativa do pintor em dar voz à manifestação da psique onírica com o uso de "imagens poderosas e, muitas vezes, chocantes, seus fantasmas, seus desejos e suas fantasias, ou, como preferem alguns, seu inconsciente" (PUPPO, 2011, p. 5). Logo, é em 1929 que Dalí apresenta o marco-estético de sua visão surrealista: O jogo lúgubre (vide anexo, figura 30, p. 146). Na pintura a óleo e colagem sobre cartão, de 44 x $30 \mathrm{~cm}$, essa empreendida no fogo cruzado entre a poética surrealista e traços do automatismo genealógico de Breton, observamos Dalí produzir

a narrativa do sonho [na qual] justapôs elementos incongruentes e formas monstruosas; empregou também diversos motivos [...] como objetos de uma fobia obsessiva própria [...] que coloca a narrativa onírica em um espaço ilusionista, tridimensional -, Dalí faz uso aqui de uma "paisagem" mais fragmentada. [...] Não há uma unidade coerente na figura; apenas a soma dessas partes fragmentadas. Mas não é somente essa figura que está "desmembrada"; além de alguns elementos realmente "colados" na tela, a pintura como um todo emprega uma técnica semelhante à colagem para agrupar fragmentos epartes [...], esse tipo de efeito [compara-se] com as técnicas automatistas de Masson e Ernst (FER, 1993, p. 200).

Com isso exposto, notamos: primeiramente, que Dalí, inspirado na estética de Ernst, se serviu do repertório de motivos freudianos e se concentrou, daí a diante, no imaginário sexual. Acima de tudo,

é talvez o tema da masturbação e a culpa decorrente que preocupa Dalí, e isso é sugerido [na referida pintura] pela calça manchada da figura masculina em primeiro plano, a imensa mão da estátua, a mão cobrindo os olhos 
da estátua e o simbolismo sexual do qual a pintura está repleta (FER, 1993, p. 200).

Por conseguinte, pontua-se que os saberes estéticos de Dalí são admitidos pelo establishment como a arte ("verdade-arte")

a mais alucinatória até agora conhecida, [essa] constitui uma ameaça real. Ameaça, qual seja a ordem estabelecida e à aparência das coisas, mas com uma força crítica: com a vinda de Dalí, é quiçá a primeira vez que as janelas da mente se abrem com amplidão, de forma a se poder sentir planando em direção à selvagem armadilha celeste (FER, 1993, p. 200).

De resto, sobre Salvador Dalí, tendo explanado a esteira estético-patológica onírico-sexualizante em que se inscrevem reconhecidas pelo establishment (inaugurada a partir de 1929 com O jogo Lúgubre) as obras do pintor catalão, igualmente como jaz em Jovem Virgem Auto-Sodomizada pela sua Própria Castidade, salientamos ainda que, não obstante, Dalí "também foi um dos primeiros artistas a perceber o poder da mídia e criar para si uma aura de excentricidade, o que ajudou a promover a sua figura esua arte (PUPPO, 2011, p. 5). Do mesmo modo o faz Yayoi Kusama.

Se servindo de seu Kusama World e por meio de estética-patológica própria (seus pontos e acumulações fálicas em referência sexual à sua neurose obsessivo-compulsiva, o transtorno de despersonalização e a depressão) a artista - sujeito que hojeocupa a posição "artista-louco" no establishment internacional das artes - repete o feito de Dalí. Isso, através de

exposições, encomendas, projetos de mídia e empreendimentoscomerciais [pelos quais] Kusama continua a desafiar as expectativas e a superar impedimentos para trazer sua visão de auto-obliteração a públicos ainda maiores e mais diversificados (MORRIS, 2014, p. 59).

Diante de todo o exposto, diante da formação dos saberes estético-patológicos pontuados no establishment (surrealista e contemporâneo), esses atribuídos à Dalí e à Kusama, conforme se depreende percebemos então vida e obra de Kusama atravessada tanto pelos fantasmas fálicos da patologia freudiana, como aqueles oriundos da estética daliesca. Assim, verificamo-lo, primeiramente, em razão da possibilidade de repetição do enunciado verbal de Dali, Jovem Virgem Auto-Sodomizada pela sua Própria Castidade, 


\section{Eu, Yayoi Kusama, que pintei minha obliteração, minha obsessão e minhas fobias}

no qual ressoam discursos de ordem patológica e estética nas margens do enunciado verbal de Kusama Auto-obliteração de Kusama. E agora, para passarmos à análise da materialidade pictórica significante sugerida, apresentamos como objeto de análise deste ponto de nosso estudo, o seguinte enunciado não verbal de Kusama:

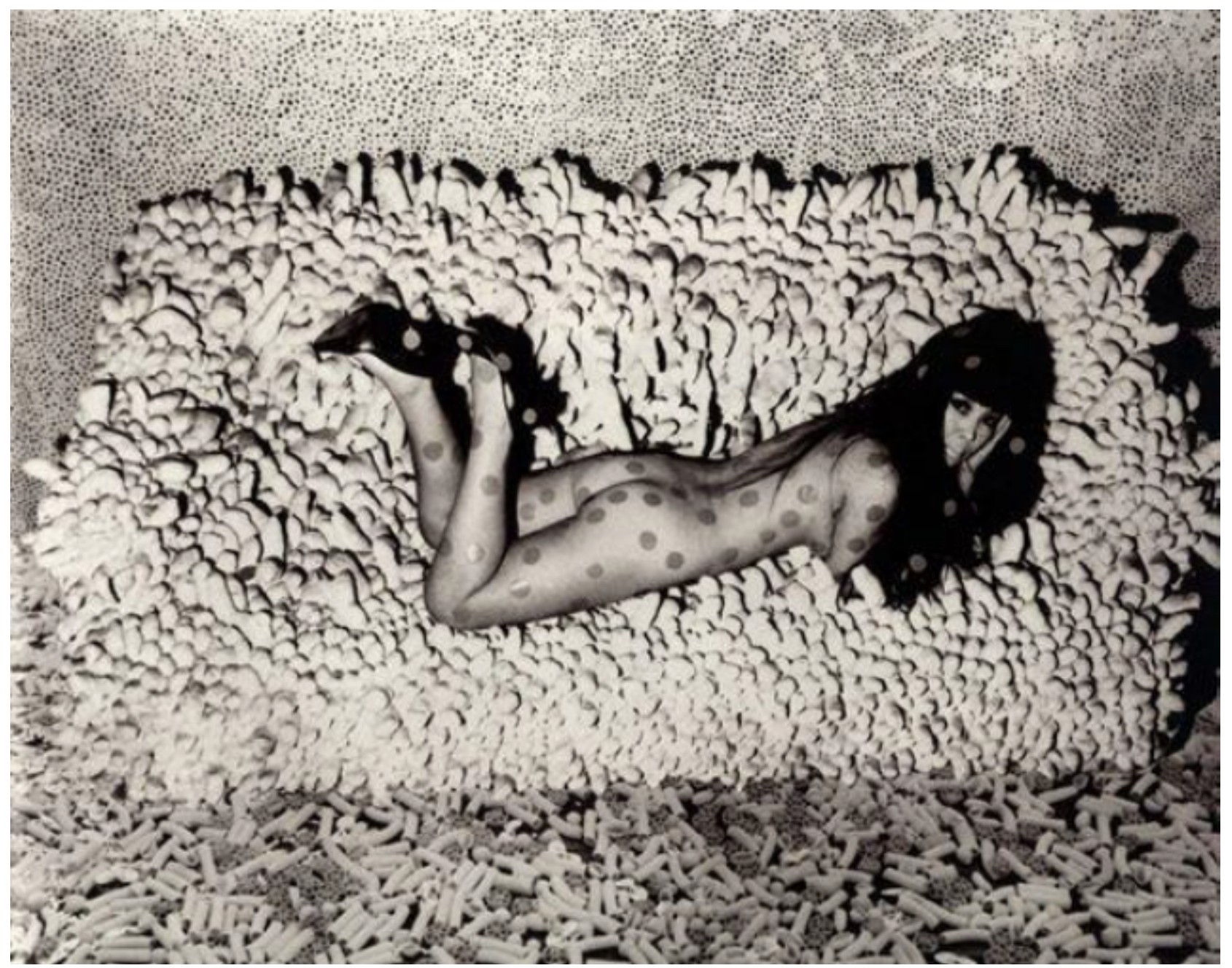

Figura 8-Obsessão por sexo e comida. Photo (C) Hal Reiff, 1966.

Fonte: MORRIS, 2013, p. 126.

\section{Semiologia Histórica: da repetição estético-patológica de indícios em imagens entre Kusama e Dalí}

Passados os pressupostos sobre a relação entre o Surrealismo, a Psiquiatria freudiana e Dalí, para realizarmos uma análise imagética do enunciado referido, nesse passo aproximamos à Análise do Discurso ao paradigma indiciário baseado na Semiótica, aquela de raízes mais antigas, conforme estatui Ginzburg. Nosso intuito a partir desse segmento da pesquisa é verificar, primeiramente, no enunciado imagético Obsessão por sexo 


\section{Eu, Yayoi Kusama, que pintei minha obliteração, minha obsessão e minhas fobias}

e comida pistas que permitam captar aí redes de reminiscências pessoais e de memórias coletivas capazes de revelar a figura do sujeito histórico "artista-louco" atualizado sob a máscara de Yayoi Kusama.

Dessa maneira, escavamos o referido enunciado atrás de pistas que nos revelem, mais precisamente, sintomas (a pensar possíveis rastros, certa materialidade da patologia estética de Kusama nessa imagem), sintomas esses baseados em indicios conforme a detecção no material significante da imagem (tal qual investidos de um gesto analítico à la mode Sherlock Holmes). Junto a isso, a partir da leitura dos signos pictóricos dessa imagem, no sentido morelliniano do termo, quer dizer, diante de seus pormenores reveladores, mostraremos através desses um conjunto de elementos que será então disposto num catálogo memorial de imagens.

Ou seja, arrolaremos tais dados numa relação intericonica, conforme nos ensinou Courtine, delineando assim o sujeito histórico "artista-louco" - posição que acenamos hoje ocupada por Kusama. Dessa maneira é que mostramos a atualidade desvelada desse sujeito, isto é, pela decifração dos rastros de sonhos, imagens já vistas, esquecidas, ressurgidas, ou mesmo fantasiadas que, nesse caso, assombram oimaginário estético-patológico de Kusama, por sua vez, rastros esses depositados nas margens tanto do enunciado $O b$ sessão por sexo e comida, como noutras materialidades conforme revelaremos a diante.

Para tanto, principiamos buscando certo tipo de unidade (o retrato estético- patológico da loucura) a partir da prática da fragmentação e do efeito do estranho (o modo como são/foram tratadas as questões da sexualidade em face das forças metafóricas de alguns dos dramas e motivações psíquicas que alimentaram/alimentam a imaginação surrealista e contemporânea), isso num dado espaço específico do tempo. Dito isso, devemos considerar "Obsessão por sexo e comida" (1966, figura 8) de Yayoi Kusama além da produção de sentidos que essa imagem provoca.

Logo, é preciso pensar essa obra em relação ao povoamento de ideias arroladas àsua exterioridade histórica a fim de admitir essa imagem, portanto, como uma unidade discursiva. Para delineá-la como tal precisamos alocá-la ao conceito de "memória discursiva" desenvolvido por Courtine (2013), o qual, estudado inicialmente no seio dasformulações linguísticas trouxe a noção de repetição para os estudos das imagens. Assim, pensada 


\section{Eu, Yayoi Kusama, que pintei minha obliteração, minha obsessão e minhas fobias}

num modelo de língua, a noção de memória discursiva se baseia na ideia de repetição da existência histórica dos enunciados, a rigor, esses em termos foucaultianos. Confere nisso, portanto, a possibilidade de promovermos tal casamento teórico para realizarmos a análise proposta. Isso posto, antes de nos atermos à repetição do discurso estético-patológico da loucura no que concerne a produção da imagem do sujeito "artista-louco", comecemos com a análise da repetição estético-patológica no interior do objeto propriamente dito, lido aqui como um enunciado "obra-prima".

Diante das perspectivas teóricas acenadas, a unidade discursiva que elegemos em nossa pesquisa faz com que Obsessão por sexo e comida seja desse modo analisada fora da estreiteza limítrofe de seu volume material $(23$ x $31 \mathrm{~cm})$. Quer dizer, colocamos assim a obra em relação com outras obras e com outros lugares, com isso fazendo emergir então sentido(s) que nasce(m) das relações de práticas vivenciadas no cotidiano, essas tomadas a partir de seus intrincamentos com as produções de poderes e saberes, ou seja, certos conhecimentos específicos - aqueles comuns aos artistas-loucos, não outros artistas quaisquer.

Conhecimento esse que entendemos aqui associado à posição que um determinado sujeito (Yayoi Kusama) vem a ocupar diante várias relações estabelecidas, diante de vários objetos com os quais ele cruza durante sua prática cotidiana (como a prática estética daliesca da fragmentação e do estranhamento em função de uma nova produção estética para a loucura, conforme estatuem os poderes-saberes do establishment). Dessa maneira, demarcam-se lugar, tempo e a posição que revelam o espaço desse sujeito na história e na memória; um triplo encadeamento que expõe assima produção dessa respectiva identidade - ou seja, Yayoi Kusama, hoje artista-louca como outrora o foi Salvador Dalí.

Comecemos, primeiramente, tomando Obsessão por sexo e comida em sua singularidade. Nesse sentido, compreendemos a referida obra de Kusama como um enunciado a partir do conceito estabelecido por Foucault (2010), no tocante a dizer com isso que o enunciado "não é uma frase", tão pouco somente se revela por meio dos constituintes da frase. Ou seja, ele não está essencialmente submetido a uma estrutura linguística da ordem sujeito-verbo-predicado. Melhor dizendo, o enunciado não sesubmete apenas aos seus caracteres gramaticais. 


\section{Eu, Yayoi Kusama, que pintei minha obliteração, minha obsessão e minhas fobias}

Também para Foucault, o enunciado "não é uma proposição". Entendemos com isso que uma proposição segue submetida ao exame do verdadeiro ou do falso, e o enunciado, estando no nível do discurso, logo, sobre ele, não se considera tais equivalências estabelecidas entre essas formulações. Não obstante, na esteira dessa discussão, para a $\mathrm{AD}$ o "enunciado não é um ato de linguagem", pois sobre ele procura- se propor a busca do ato material (falar/escrever/pintar/compor/fotografar). Logo, tão pouco se busca nele pela intenção do indivíduo que está realizando tais atos.

Isto posto, considerando que um enunciado se constitui pelo fato de ele ser produzido pelo sujeito a partir de um lugar institucional, determinado assim por regras sócio-históricas que definem e possibilitam a existência do enunciado, ligados ao pensamento foucaultiano (FOUCAULT, 2009) ponderamos que Obsessão por sexo e comida não somente como uma obra-prima de Kusama mas também como destaque da posição de um sujeito que desse modo determina o que pode e se deve dizer num dado momento. Conforme se depreende, nossa investigação da referida obra de Yayoi Kusama como um enunciado nos dá assim a dimensão adequada para refletirmos sobrea decifração da constituição da identidade do sujeito histórico "artista-louco", bem como a formação estético-patológica enraizada no interior da referida foto-arte.

Por conseguinte, apreendamos agora Obsessão por sexo e comida como sujeitos expectadores diante desse objeto. Porém, nos colocamos aqui não como um sujeito qualquer, mas sim o sujeito atrás de indícios comparável àquele detetive de Conan Doyle. Dá-se aí então o início de um processo histórico-reflexivo e de reinvenção de imagens, ou seja, construções do imaginário acerca da artista Yayoi Kusama bem como a estética de sua patologia. Isso porque, nesse turno, nosso corpo ao mesmo tempo em que produz imagens é também receptor delas. Dito de outro modo, é

a partir do médium, isto é, do suporte material que é o seu, médium visto, mas igualmente a partir de um corpo olhado. [Não obstante,] a particularidade do corpo que pode ser um médium também, isto é, que ele é o médium, o suporte das imagens internas" (COURTINE, 2013, p. 44).

Com isso, consideramos aí o transito de um arquivo imagético, apontando, de um lado Obsessão por sexo e comida - aquele apreendido de nosso olhar e que entrará em contato com nossas imagens internas, e, do outro, Obsessão por sexo e comida - o tra- 


\section{Eu, Yayoi Kusama, que pintei minha obliteração, minha obsessão e minhas fobias}

balho em si - imagem externa a nós no qual se inscrevem camadas de indícios da produção material do trabalho da artista nipônica. Olhar para o ajuste de uma imagem nessa rede, desse modo, significa "olhar discursivamente para um objeto que se desloca de seu ponto inicial para se inserir e se juntar a margem com outros enunciados" (MILANEZ, 2015, p. 20), revelando, desse modo, tal arquivo de imagens. Por tanto, diante dessa imagem externa, primeiramente, nos atemos agora à detecção do seguinte material significante inscrito nesse enunciado (figura 8) por sua vez disperso/compondo o cenário através de: a coloração; o sofá coberto de falos; a idealização da composição fotográfica e o enquadramento dos planos.

Nessa linha, escavando as primeiras camadas de Obsessão por sexo e comida (figura 9) buscamos colocar revelo na constituição histórica da estética da loucura segundo assevera o establishment (a pensar aí a relação de saberes de Freud e Dalí), ou seja, os sentidos estético-patológicos que a própria materialidade do enunciado imagético oferece. Da observação direta da base de seus indícios superficiais, dessa maneira pontuamos os seguintes os elementos destacados abaixo: o espaço (piso e parede), a ausência de cores, as sombras projetadas, o sofá, os falos, as peças demacarrão e os sapatos se salto-agulha. Vejamos esses na obra e nos pormenores destacados a seguir:

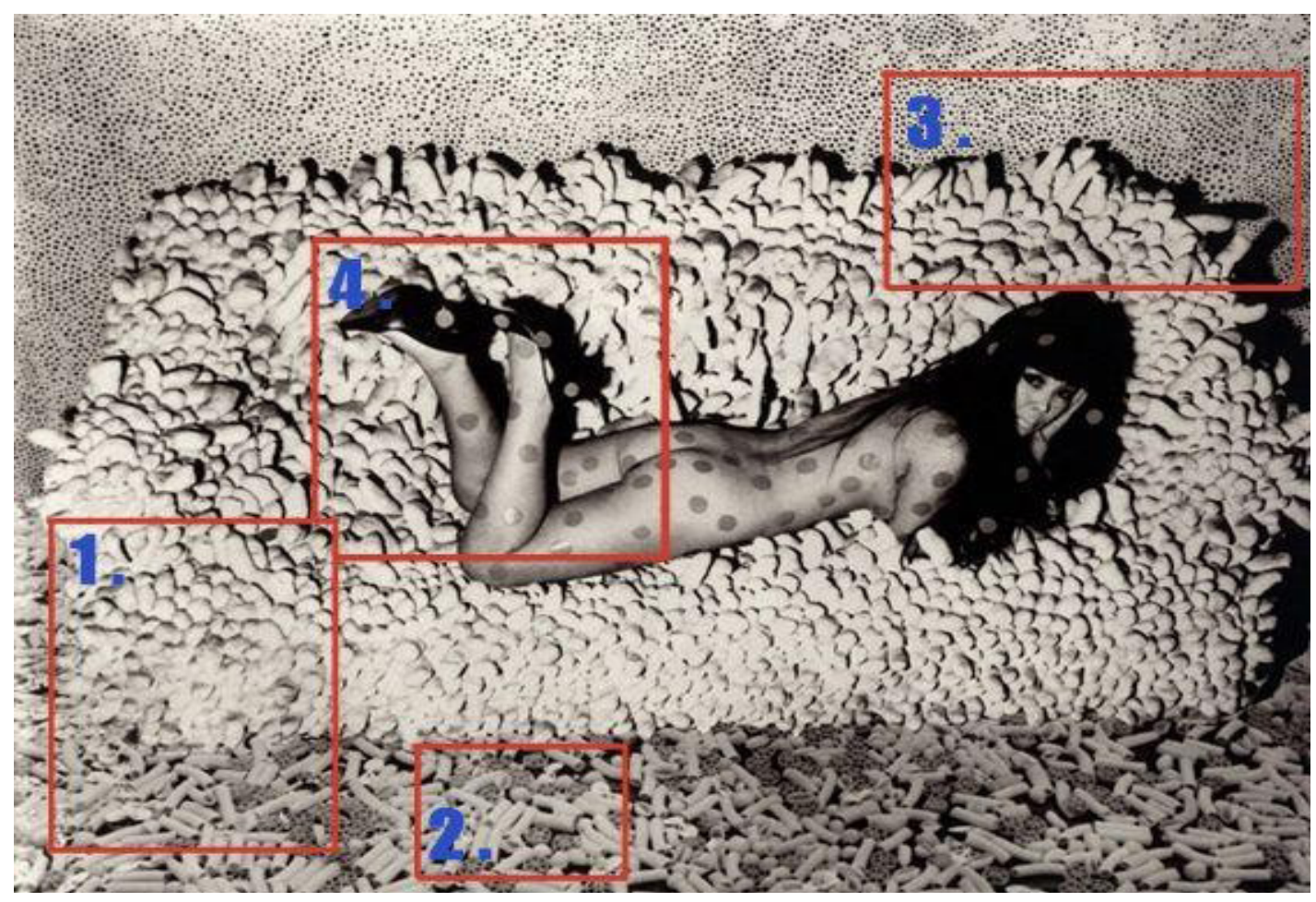

Figura 9 - Obsessão escandida 1. Photo (C) Hal Reiff, 1966.

Fonte: MORRIS, 2013, p. 126. 


\section{Eu, Yayoi Kusama, que pintei minha obliteração, minha obsessão e minhas fobias}

Eis a foto-arte de Yayoi Kusama, outrora pela ótica de Hal Reiff (figura 9), agora escandida. Contemplemos e vejamos a obra pelo alcance do paradigma indiciário associado à Análise do Discurso foucaultiana. De seu espaço, chamamos a atenção para a totalidade uniforme do lugar enquadrado - efeito por sua vez reforçado pelo tratamento guarnecido à fotografia, no caso, a saturação em preto e branco. De suas formas, vemos que tanto "piso" e "parede" são compostos por macarrões de formatos cilíndricos, esféricos e esférico-estrelados (pormenores 2 e 3 - figuras 11 e 12). Já o conjunto desses objetos se sobrepõe quase anulando os contornos do lado esquerdo da base do sofá (pormenor 1 - figura 10), esse composto por falos de diversos tamanhos fazendo-o, com isso, quase levitar na cena pré-projetada, não fosse a sobra projeta do encosto do sofá sobre a "parede" (pormenor 3 - figura 11).

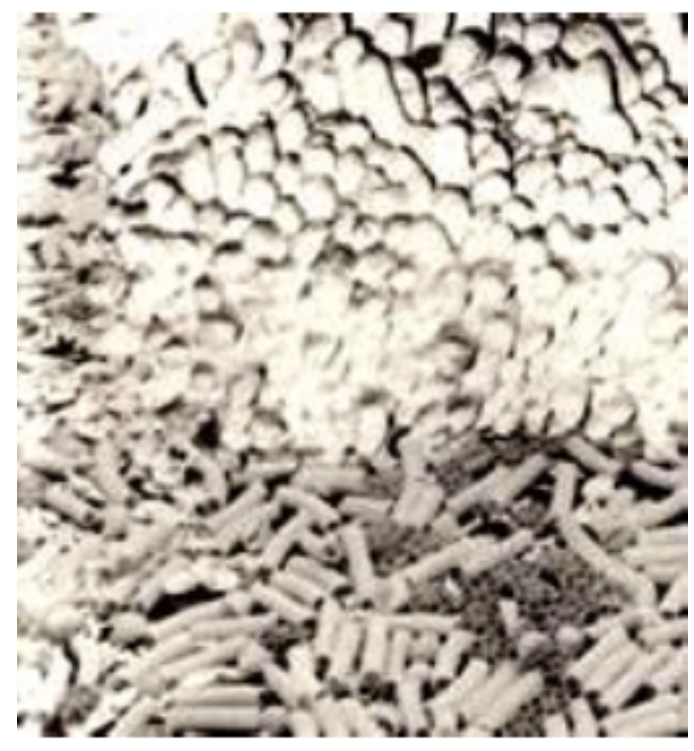

Figura 10 - pormenor 1

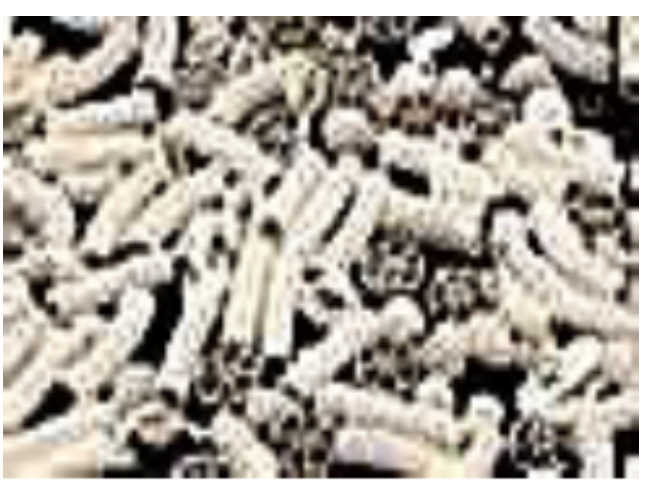

Figura 11 - pormenor 2

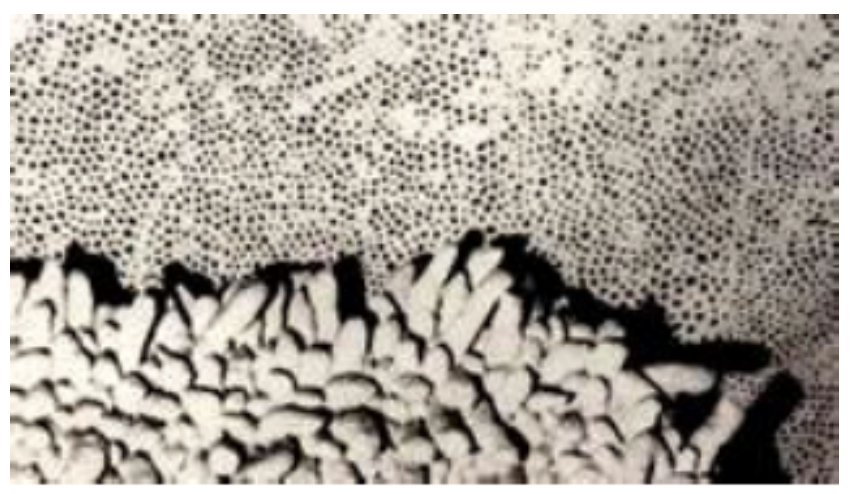

Figura 12 - pormenor 3 


\section{Eu, Yayoi Kusama, que pintei minha obliteração, minha obsessão e minhas fobias}

O que apreendemos desse primeiro lance de olhar? Esse conjunto de repetições de marcas formais cilíndricas da imagem faz nosso olhar convergir sobre a repetibilidade dos falos e dos objetos comestíveis. Assim, fundem-se as figuras do piso, parede e sofá provocando um primeiro efeito de estranhamento; esse inapreensívelnuma primeira vista da foto-arte. Interpretando essas marcas de repetibilidade internas à fotografia, retomamos as formas de comparação no que diz respeito à medida e à ordem, de acordo com o postulado arqueológico foucaultiano, mais precisamente apresentado em As palavras e as coisas (1966).

Tal forma de compreensão, de um lado, tem como objetivo visar à análise de uma "unidade comum" (FOUCAULT, 2000, p. 73), a qual toma uma pela outra como unidades de empréstimo, isto é: a base do móvel (sofá) toma o cenário (piso) como empréstimo (figura 10). Logo, as formas cilíndricas dos objetos comestíveis que compõem o piso tomam o formato cilíndrico dos falos que compõem o sofá como empréstimo, assim sucessivamente, tendo-se nisso o padrão da repetição. De tal modo, do outro lado, a ordenação desse movimento que se estabelece propicia "uma referência a uma unidade exterior [...], descobrindo aquela que é a mais simples, em seguida aquela que é mais próxima para que se possa aceder necessariamente, a partir daí, até as coisas mais complexas" (FOUCAULT, 2000, p. 73).

Prosseguindo, a essa altura, deslizando os olhos dos falos para as peças de macarrão, começamos a nos inquietar com a escala desses objetos de ordem comestível. $\mathrm{Na}$ retratação desses, falta coerência (proposital?) com as suas proporções "reais" (figuras 13 e 14, pormenores aproximados verticalmente respeitando a proporção da escala da obra); tendo-se em vista os macarrões cilíndricos dispostos no primeiro plano apresentarem uma escala similar àquela dos pés da artista que posa nua sobre o sofá no plano central da imagem, onde adejam os pés gravitando ao lado de falos. Verifiquemos as proporções relatadas (representadas pelas setas-duplas vermelhas) dado os alinhamentos vertical (flechas pretas) e horizontal (linha azul) propostos abaixo: 


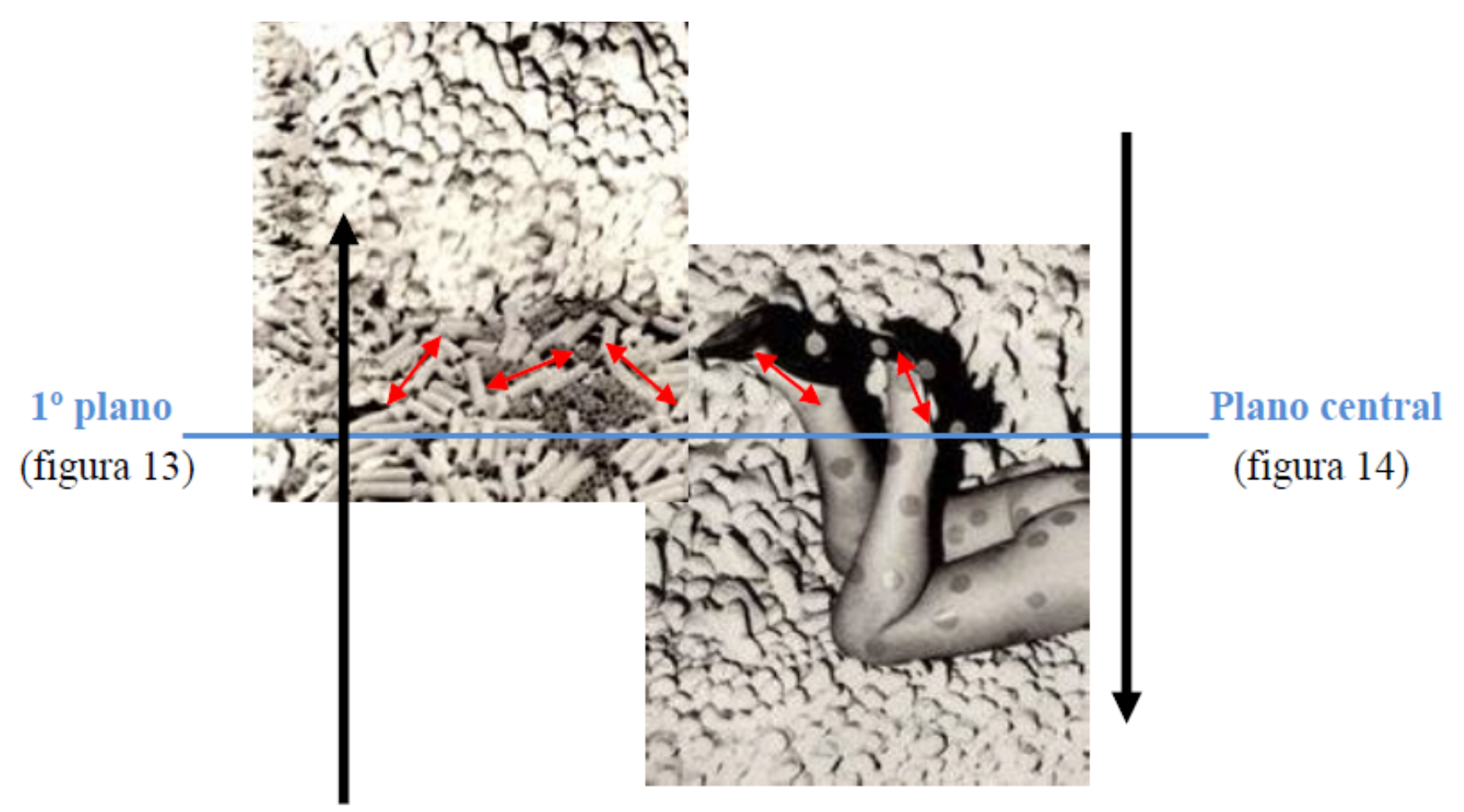

Poderíamos com essa aproximação de desproporções (entre as peças de macarrão e pés) permitida pelo efeito estético do estranhamento indicar a sugestão um traço patológico-obsessivo por comida referido a analogia sexual do fetichismo por pés e sapatos femininos de salto-agulha? Ora, a função simbólica para os objetos, tal os sapatos, enquanto prática na estética surrealista daliesca remete

\footnotetext{
a encarnação desses desejos, seus meios de objetificação pela substituição e pela metáfora e suas expressões simbólicas constituem o processo típico de perversidade sexual, o que é de todas as formas similar ao processo de criação poética (FER, 1993, p. 224).
}

Parece-nos convincente aí a alusão poética dos sapatos ao fetichismo sexual simbólico, uma vez que seguem enredados/visualizados os termos subsequentes extraídos dessa materialidade significante: o desejo sexual por pés objetificado/substituído pela presença dos sapatos (objetos não comestíveis) dada à aproximação irregular de escala. Dessa maneira, esse objeto se torna "comestível" - comestível entendido aqui pela conotação aludida ao ato sexual, uma vez aí implícita culturalmente pelo uso do verbo "comer".

Ora, esse sentido evocado em 'comer' constrói a formação de um campo que ultrapassa (semanticamente) os limites da alimentação. O uso aí incidido atribui valor de uma significação que desliza do processo alimentar para o corpo erotizado, descre- 


\section{Eu, Yayoi Kusama, que pintei minha obliteração, minha obsessão e minhas fobias}

vendo possibilidades nas relações amorosas entre dois indivíduos (ou mais), dessa forma regulamentando um lugar para o sexo, bem como abrindo a porta da intimidade e dos desejos do sujeito arrolados aos objetos de desejo - como os sapatos femininos - remetidos, nesse enunciado em questão, pelos ecos de nossa cultura visual. Tem-se ai, inicialmente, o avanço de nosso arquivo coletivo, esse patrimônio de "imagens delembranças, as imagens de memória, as imagens de impressão visual armazenadas pelo indivíduo" (MILANEZ, 2009 , p. 219). Por conseguinte, a exposição da memória coletiva de nossas imagens visto o processo da intericonicidade - traz à tona desse enunciado o campo do discurso sexual e dos fetichismos.

Dito isso, voltemos nesse passo para o espaço inscrito nesse enunciado o qual aproximamos para outros dois traços estéticos patológicos surrealistas. No mesmo tempo que se verifica a existência do "piso" e da "parede" ali projetados (figuras 10, 11 e 12, respectivamente os pormenores 1, 2 e 3), os mesmos desaparecem de lá nomomento em que atemos nossa atenção no encontro dos contornos da base e das costas do sofá. Releitura surrealista da técnica de pintura tromple l'oil; um enganador golpe de visão? Cremos que sim, este 'golpe' aí operado pela técnica da decoupage - corte e colagem de elementos de forma a compor uma imagem pictórica/fotográfica; nesse caso, engendrando a totalidade da estrutura pictórica que compõem esse enunciado. Com isso em mente, agora o espaço se mostra não mais diluído em seus planos mais sim emerge fragmentado: não há qualquer unidade espacial coerente na imagem.

Nesse sentido, o que a fotografia provoca com esse espaço de dimensões distorcidas, irreais para com as dimensões originais, é um segundo estranhamento, o qual direciona agora a imagem à tessitura de sua narrativa onírica. Vale dizer também que a construção do discurso do estranhamento, essa emparelhada à ordem arqueológicadas unidades de empréstimo, ainda se atrela a questão da noção de duplo, visto que "da repetibilidade dos traços formais chegamos à configuração de um tipo de série que nos coloca lado a lado com a circularidade e volta da imagem com num espelho, provocando um sentimento de estranhamento" (MILANEZ, 2015, p. 202).

Diante da ideia de estranhamento, nesse passo gerada pela duplicidade na repetição dos elementos da imagem de Obsessão por sexo e comida é que atrela-se à estética de 


\title{
Eu, Yayoi Kusama, que pintei minha obliteração, minha obsessão e minhas fobias
}

Kusama a visão freudiana do "estranho" tão recorrente o ideário estético surrealista. Para prosseguirmos em tal perspectiva, verifiquemos inicialmente o "efeito de estranhamento" de Freud emprestado pelos surrealistas para trazer uma luz sobre o material significante estético que escandimos.

O referido termo de Freud parte de seu estudo dos léxicos unheimlich e heimlich. O primeiro traduzido para o inglês como uncanny "["estranho"], é o oposto de heimlich (“doméstico" ou "familiar" e, portanto, "não-estranho")" (FER, 1993, p. 196). O que interessa a Freud, como se observa, é "esse sentido de estranho combinado com o de familiar: é um termo ambíguo já que implica também seu oposto" (FER, 1993, p. 196). Em síntese, Freud desenvolve esse conceito discutindo como o "estranho" é abordado em $O$ homem de areia (1817) de E.T.A. Hoffmann. A discussão de Freud gira em torno da boneca Olympia, um personagem autômato, mas com a aparência de uma mulher real de tal forma que o herói se apaixona por ela. Porém, para Freud

\begin{abstract}
Olympia não é o principal responsável pelo efeito de estranhamento da história, mas sim a figura do "Homem de Areia", a imagem do pai que pune as crianças arrancando seus olhos. Como um contraponto agradável na história, Coppola, que criou o autômato Olympia, é também um oculista. [...] Isso atraiu Freud, que viu no medo de perder a visão como um medo simbólico da castração. Olympia talvez pareça ser a origem do efeito do estranho, mas por fim é apenas um tipo de álibi. O temor real está no medo do pai e da vingança do pai sobre o filho, com a castração (FER, 1993, p. 196).
\end{abstract}

Ou seja, sendo o efeito do estranho a constituição daquilo que é simultaneamente novo e familiar, no entanto sem os dicotomizar, isto é, tomar o que está oculto e o que é conhecido como constitutivo, nessa estrutura freudiana, "as partes desmembradas podem evocar o estranho, mas também o pode um texto e uma imagem "desmembrada", em que as peças são justapostas num modo não familiar" (FER, 1993, p. 197). Com isso aproximamos essa ocorrência freudiana no caso do enunciado imagético Obssessão por sexo e comida. Dessa maneira emparelhado ao efeito do estranho - efeito também tomado por empréstimo pela esteira surrealista daliesca, é que se pode abordar essa obra "como um "duplo", como um espelho, ou espírito guardião, ou uma imagem repetitiva" (FER, 1993, p. 197). A partir disso, assim ponderamos a materialidade da língua, a exemplo de 


\section{Eu, Yayoi Kusama, que pintei minha obliteração, minha obsessão e minhas fobias}

Milanez, tal como

tomada como análise do conto O homem de areia de E. T. A. Hoffmann, para pensar as imagens inconscientes que suscitam e configuram a ambivalência da construção da sensação do estranho. Obviamente, [não reduziremos] a significação dessas imagens às idéias de castração, por exemplo, mas, certamente [buscaremos] qual éa ordem que regula esse sentimento estranho, marcado pela agradabilidade do familiar e sua sombra, que opaciza significados e oscoloca fora de nossa vista (MILANEZ, 2015, p. 202).

Isso posto, o efeito de estranho que apreendemos em Obsessão por sexo $e$ comida diz respeito a "não-cena" que observamos: ela é apenas a soma de suas partes fragmentadas. Trata-se da produção desse domínio estético em função de uma representação pictórica do inconsciente vertendo num fluxo que nos permite compreender, em sua extensão discursiva, e, simultaneamente, a ideia do novo e do familiar como discurso. Noutras palavras, o suporte imagético "fotografia" que deveria retratar fielmente o espaço fotografado (o ateliê em que repousam o sofá e a artista) tem desse modo seu propósito subvertido/desfamiliarizado/deslocado diante de uma"novidade", que é a apreensão óptica (o trompe l'oil/golpe de visão) sobre esse espaço onírico multidimencionalizado da estética de Kusama (em consonância com a verve onírica surrealista). Tudo isso viabilizado, em termos de composição, pela repetibilidadevisualizada na relação que se estabelece aí pelas unidades de empréstimo mapeadas a partir de sua materialidade significativa.

Uma vez acenados os traços estético-patológicos em Obsessão por sexo e comida, como se verificaria agora a inscrição desse enunciado nesse catálogo memorial de imagens surrealistas? Ora, articulando-o a partir de uma segunda camada de materialidade de sentidos, esses mais superficiais, e, portanto, desse modo mais detectáveis nas superfícies de outros possíveis enunciados. Falamos, nesse passo, mais precisamente do corpo nu disposto confortavelmente relaxado ao redor de falos quepaira sob um cenário fragmentado, quase dissolvido (figura 15). Tal disposição corpóreanos remete à outra, justamente em sintonia à construção estético-patológica daliesca. Estética peculiar que nos leva a voltar, outra vez, à Jovem Virgem Auto-Sodomizada pela sua Própria Castidade (figura 16): 


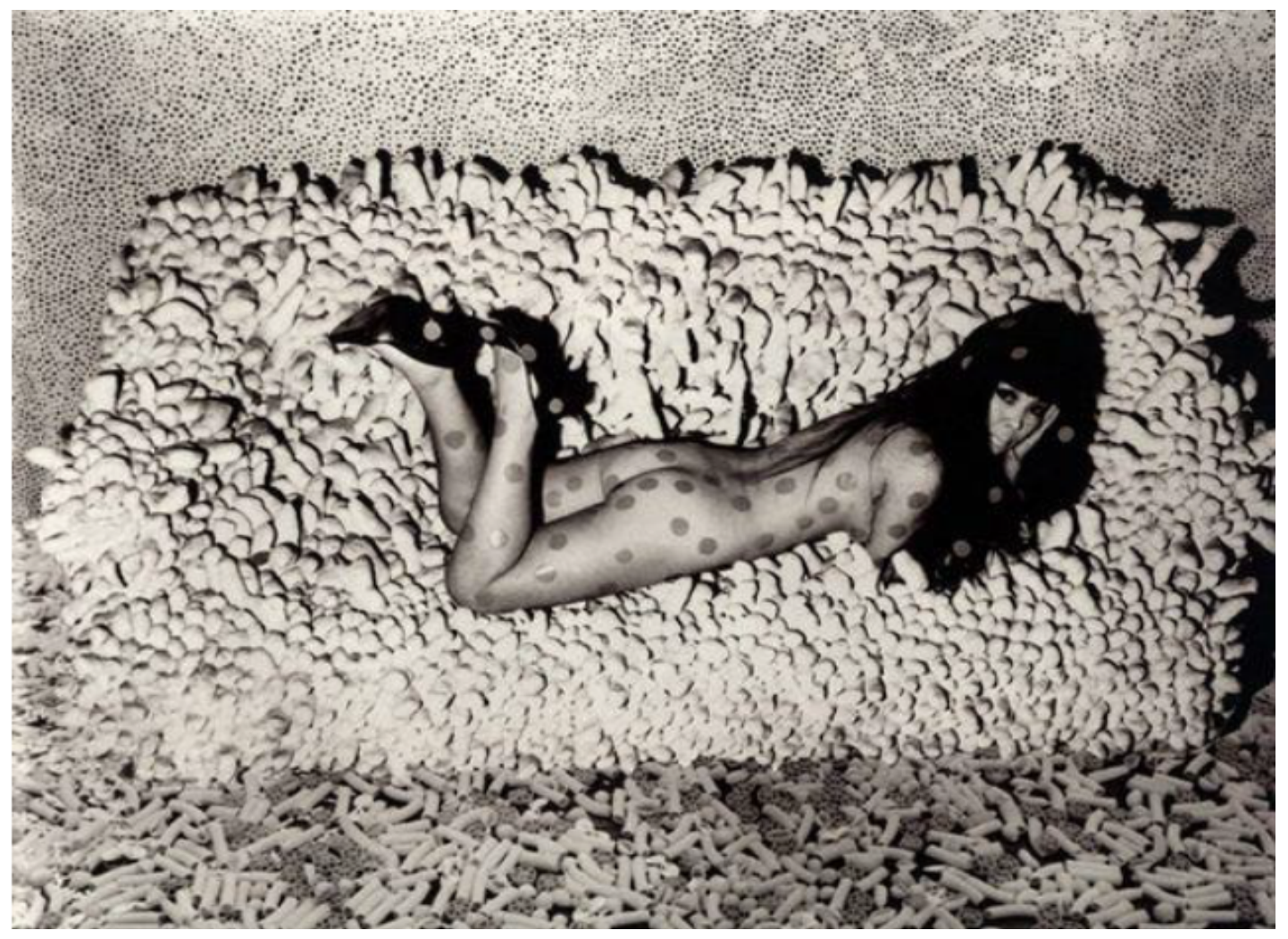

Figura 15 - Obsessão escandida 2. Photo CHal Reiff, 1966, MORRIS, 2013, p. 126.

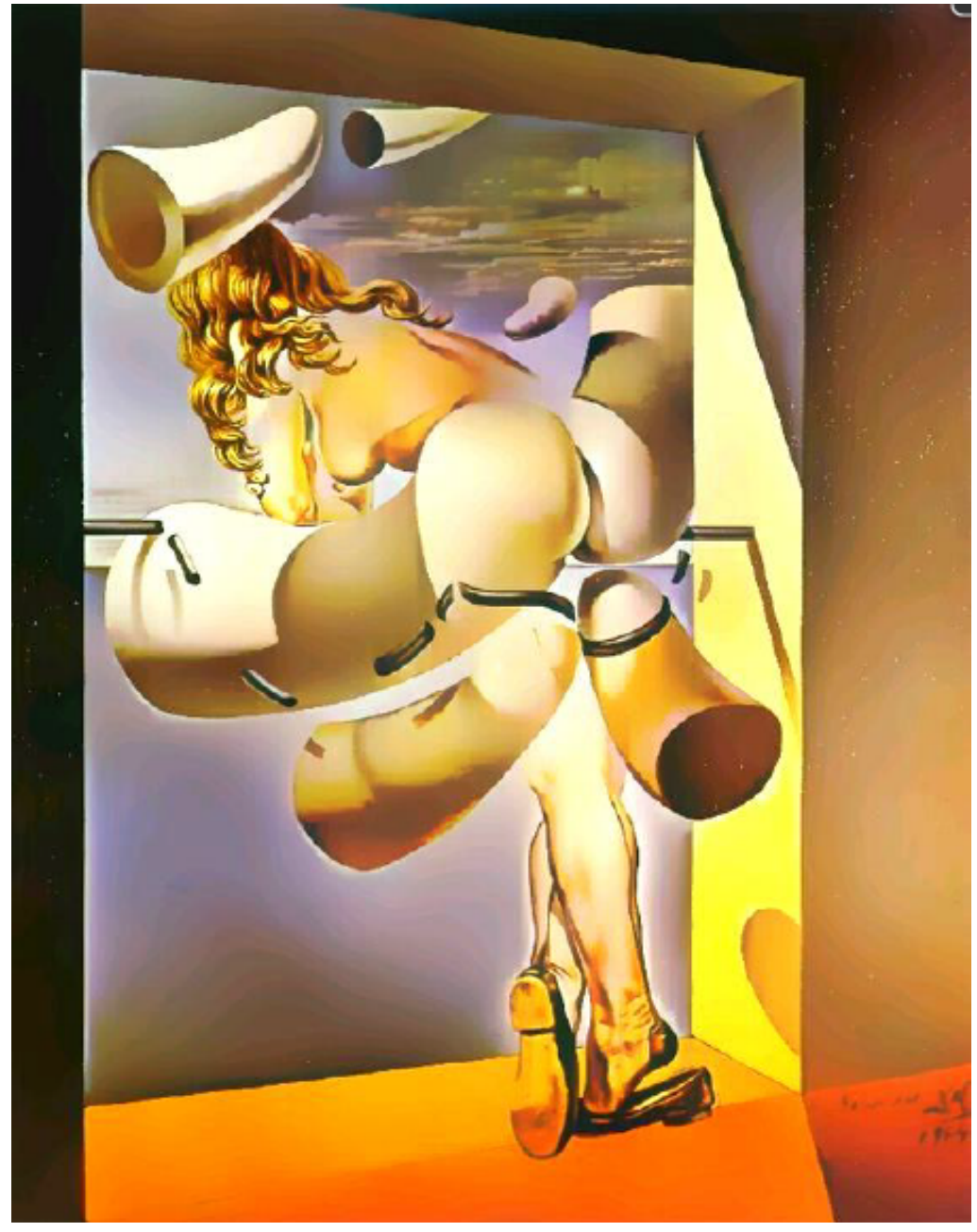

Figura 16 -Virgem Auto-Sodomizada

Fonte: escandida. Fonte: BECKETT, 1997, p. 364. 


\section{Eu, Yayoi Kusama, que pintei minha obliteração, minha obsessão e minhas fobias}

Emparelhados assim os enunciados Obsessão por sexo e comida e Jovem Virgem Auto-Sodomizada pela sua Própria Castidade é que apreendemos reverberando nas margens enunciativas do corpo unidade discursiva inscrito na materialidade discursiva da foto-arte - a jovem Kusama auto-obliterada - as mesmas materialidades significantes que compõem, em seu expediente, o corpo, unidade discursiva, da jovem virgem auto- sodomizada de Dalí. Do ajustamento dessa detecção de materiais significantes emambas as imagens, vemos concomitantes, primeiramente: o uso estético patológico da fragmentação e do estranhamento na construção espacial (em ambas as imagens os espaços são "não-cenas", são apenas a soma de suas partes fragmentadas). No caso da pintura de Dalí, a "porta" é ao mesmo tempo uma "janela" cujo beiral funde-se ao "piso laranja" por sua vez fundido ao "céu/oceano" azuis.

Por segundo: pontuemos a forte presença dos falos e da analogia surrealista ao feminino. Feminino aqui inscrito em sua forma corpórea. Na foto-arte de Kusama, os falos ocupam grande porcentagem da imagem. Distribuem-se ali de forma acumulada produzindo a estrutura de um sofá. Coroando essa construção, em seu centro pousa o corpo feminino nu, numa compleição que fortalece a verve erótica do feminino, tão fundamental à estética surrealista. Já no caso da pintura de Dalí, embora a quantidade defalos seja menor, é, no entanto, mais expressiva. Em sua escala ocupam também grande parte da pintura. E, nesse duplo expediente pictórico, ora vemos aí apenas falos, ora vemos em sua união formar-se o corpo de uma jovem nua, não morena mas loira, porém sua linguagem fálico-corporal lhe torna tão a vontade quanto posa à jovem Kusama, ambas calçando nada mais que sapatos pretos.

Articulando a imagem de Kusama no catálogo memorial de imagens surrealistas, desse modo amalgamamos a estética dos sonhos patológicos. Desse feito ressurgem, sobremodo dessa relação intericonica exposta, indícios e rastros (detectados a partir de uma camada superficial do material significativo dos dois enunciados) que assombraram o imaginário discursivo da loucura outrora depositados na referida pintura de Salvador Dalí.

Tendo com esse gesto analítico, inicialmente tal como nos ensinou Ginzburg, apreendido e destacado nas camadas materiais de sentido internas e externas de Obsessão por sexo e comida traços, indícios e signos pictóricos essencialmente ligados às particula- 


\section{Eu, Yayoi Kusama, que pintei minha obliteração, minha obsessão e minhas fobias}

ridades de nosso objeto de estudo, mostramos assim a existência de sintomas(a fragmentação, o efeito do estranho) que permitem transparecer a identidade estético-patológica da loucura proposta no enunciado imagético de Kusama. Da observação que enredamos pontuamos que o curso interno na rede de sentidos dentro da foto-arte por fim desloca nosso olhar do que é previsto (o retrato de uma mulher nua deitada sobre um sofá) para uma ruptura de sentidos acerca do espaço onde se insere essa mulher nua deitada sobre um sofá.

Ruptura, por sua vez, que passa a ser atribuída em oposição, em contradição ao próprio espaço fotografado. Isso pois os signos pictóricos que o compõe a totalidade da cena (o sofá, a parede, o piso, os falos, as peças de macarrão) uma vez imbricados pela repetibilidade das unidades de empréstimo foucaultianas, levam-nos a um lugar desconhecido - mas ainda estranhamente comum - dada sua organização (a disposição fragmentada desses elementos) apresentada de maneira estranha a nossos olhos. É assim que embarcamos no sonho preto-e-branco de Kusama. Nosso olhar navega a deriva aí em consequência dessa morfologia icônica singular nos provocando princípios que evidenciam (graças ao seu próprio gesto estético) uma teatralização da estética surrealista, essa, na obra de Kusama forjada também pelo princípio do efeito do estranho.

Ou seja, vemos em Obsessão por sexo e comida a materialidade de um espaço calculado para surpreender, dado o seu ritmo estético, feito em harmonia com essa sequência discursiva em torno do efeito do estranhamento - traço estético-patológico da loucura apreendido dos saberes da escola surrealista. Esse teatro em que Kusama é diretora e protagonista é controlado pela ausência de cores, pelos contornos diluídos do sofá, pela aproximação das formas cilíndricas e esféricas que compõem o piso, a parede e o sofá, além do tamanho equivalente das peças de macarrão e dos falos, bem como pela brincadeira com o objeto fetiche - os sapatos que gravitam sobre a acumulação fálica que assinam aí a analogia erótica do feminino tão quista pelos surrealistas.

Toda essa disposição acena para um desregramento da ordem do sentido da familiaridade (o espaço "fielmente" registrado e "esperado" de uma fotografia) justamente porque o espaço fotografado é antes a disposição de um todo fragmentado, de ordem onírica imposta pelo olhar (conhecimento, saberes) da artista que exige de nós, os expectadores 
de sua "obra-prima", à obediência de sua "verdade-arte". Por sua vez lida verdade-choque, verdade-acontecimento, e, sobremodo, lida verdade "de agentes e portadores privilegiados e exclusivos" (FOUCAULT, 2006), aqueles que a verdade escolhe sobre quem se abater. Dente profetas, adivinhos, inocentes, cegos, loucos e sábios, na ocasião aqui analisada, ela decide debruçar-se sobre os artistas- loucos; notáveis sujeitos de estatura icônica.

\section{Intericonicidade: da repetição do discurso da loucura para o sujeito histórico "artista-louco" em imagens entre Kusama e Dalí}

Delineadas as pistas que permitiram captar, a partir das materialidades de sentido apontadas nos enunciados não-verbais de Kusama e de Dalí, finalmente atingimos à rede de reminiscência estético-patológica do sujeito Kusama, esse que apreendemos junto à memória do imaginário surrealista. Com isso, a partir dos conceitos arqueológicos foucaultianos (enunciado, unidade de empréstimo e a repetibilidade) verificamos a presença elementar dos traços estético-patológicos (a fragmentação, o estranhamento, a alusão ao feminino) lidos, segundo o paradigma indiciário de Ginzburg numa relação intericonica diante tanto dos indícios internos como externos da foto-arte de Kusama e da referida pintura de Dalí. Niveladas edesautomatizadas a estética patológica no turno de Kusama e Dalí, gostaríamos delançar um olhar sobre a construção da exterioridade do sujeito histórico "artista-louco" que se atualiza hoje sob a máscara de Yayoi Kusama.

Logo, como isso seria possível? Sem exaustividade, é da apreensão da sequência discursiva que acabamos de mostrar que reside tal possibilidade para a Análise do Discurso: sabe-se que tal sequência, como quaisquer outras, só é admissível apenas porque os discursos são repetidos através de um conjunto de marcas formais. Isso, considerando que esse tipo de composição pode ser observada por meio dematerialidades cuja existência material histórica pode então ser recuperada graças ao entrelaçamento, à associação e o reagrupamento de seus traços.

No caso de Kusama, tal conjunto de materialidades significantes internos à obra da artista-louca foi trazido à tona pela seleção de linhas e formas que compõem o imaginário 


\section{Eu, Yayoi Kusama, que pintei minha obliteração, minha obsessão e minhas fobias}

de sua obra. Isso o foi verificável por meio de um campo de antecipação de um determinado domínio (a formação discursiva da estética patológica surrealista), a qual esclarece e determina tal designação dessas materialidades que indicam certo tipo de regularidades discursivas (o efeito do estranho e da fragmentação). Prontamente, essas regularidades discursivas se dão pelas marcas formais encontradas em nosso objeto de estudo (referidas à composição do espaço onírico) que tem em seu centro (o gesto estético patológico de Kusama) suas próprias regras de formação, além de seu a priori histórico (a cena alternativa da pop arte americana dos anos 1960).

Como sabemos, a considerar os posicionamentos sócio-históricos, a análise aqui empreendida sobre Obsessão por sexo e comida não deve se reduzir apenas às marcas formais internas que mostramos, visto que aí também se engloba a produção discursiva de quem fala antes, depois ou até mesmo de modo independente daquele que enuncia. Dessa feita, cientes de que o discurso não possui uma fonte original e, no caso da fotoarte analisada, em razão da repetição das marcas que nela se repetem, combinando-se ou distanciando-se umas das outras, é que se incide certa simetria das formas numa relação desarmônica com nosso olhar. Disso, constitui-se um lugar para a existência de materialidades outras que também deflagram as marcas discursivas de um estranhamento; como visto no deslizamento de sentidos estéticos entre Kusama e Dalí.

Mediante a tanto, na busca que se segue, cabe agora detalharmos a noção da repetição e seus laços com a memória no sentido courtiniano do termo. Isto é, a memória sob forma de repetição intrínseca à ordem das imagens, que, por meio de uma relação intericonica iluminará, nesse passo, a construção da figura do sujeito histórico "artista-louco", posição ocupada hoje por Kusama. A nosso ver, a noção de intericonicidade se introduz e se alça como uma ferramenta na Análise do Discurso que serve para pensarmos a circulação e propagação dos discursos por meio de um tipo específico de repetição das imagens.

Dito isso, ao pensarmos na possibilidade de tais imagens se parafrasearem não estando no nível linguístico, e com isso, problematizando então como se daria tal repetição e sobre quais os mecanismos envolvidos nessa produção, é que se torna necessário aprofundarmos a compreensão da noção de Intericonicidade concebida por Jean-Jaques 


\section{Eu, Yayoi Kusama, que pintei minha obliteração, minha obsessão e minhas fobias}

Courtine, por sua vez embasada no postulado foucaultiano. Retomando-a:

a intericonicidade supõe [...] relacionar conexões de imagens: imagens exteriores ao sujeito, como quando uma imagem pode ser inscrita numa série de imagens, uma arqueologia, à maneira do enunciado numa rede de formulações junto a Foucault; mas também existem imagens externas, que supõem a consideração de todo um catálogo memorial da imagem junto ao indivíduo, e talvez também os sonhos, as imagens vistas, esquecidas, ressurgidas ou até fantasiadas, que assombram o imaginário [articuladas] pelo ajustamento, pela detecção no material significante da imagem, pelos indícios, pelos rastros que outras imagens ali depositaram, e pela reconstrução, a partir desses rastros, da genealogia das imagens de nossa cultura. (COURTINE, 2013, p. 44).

O que temos a ressaltar disso é que, tal como "um enunciado tem sempre as margens povoadas de outros enunciados" (FOUCAULT, 2010, p. 110), para Courtine tão pouco "não existe imagem que não nos faça ressurgir outras imagens, tenham sido elas outrora vistas ou simplesmente imaginadas" (COURTINE, 2013, p. 43). Logo,essas imagens apreendidas a partir de ícones então se articulam de forma a restituir os seus vínculos umas com as outras partindo do imaginário dos indivíduos que compartilham da mesma cultura, tendo em vista possibilidade disso dada a reverberaçãodas imagens no tecido da memória. Não obstante, seguindo o pensamento courtiniano seguido da esteira antropológica de Hans Belting (1935-), conforme estatui Milanez, resta dizer ainda que

há, assim, um laço inseparável entre as imagens exteriores e as imagens interiores que são percebidas pelo nosso olhar, pelo nosso corpo, que olha para fora e para dentro de si. Suporte das imagens vistas, vividas, imaginadas e sonhadas, o corpo é medium [...] pelo qual armazenamos, criamos, reproduzimos e reconhecemos as imagens que povoam nosso espaço mental (MILANEZ, 2015, p. 201).

Isso tudo exposto, desejamos trazer à tona uma rede de materialidades discursivas dispostas de modo a formar uma cronologia visual imagético-discursiva que,povoando o imaginário do sujeito "artista-louco", revelaria traços da produção desse sujeito. A figura deste, perturbando o nosso arquivo histórico mental de imagens faz, desse modo, aparecer algo além dos próprios contornos fechados sob a máscara do sujeito Yayoi Kusama. Nesse sentido, a imagem da artista nipônica faz surgir imagens que povoam a cultura visual das imagens já vistas, bem como aquelas que foram postas em circulação pelo Kusama 


\section{Eu, Yayoi Kusama, que pintei minha obliteração, minha obsessão e minhas fobias}

World, pela mídia impressa, televisiva, pelo establishment contemporâneo, ou ainda pela maison Louis Vuitton, isso dentro de um determinada esteira temporal e que, assim, acaba também compondo tanto o nosso como o "DNA imagético" do sujeito "artista-louco".

Portanto, sendo "a imagem como um componente constitutivo de nossos tecidos corporais [fazendo] de nosso corpo uma 'mídia viva"" 45 em meio a esse arcabouço de imagens que podemos sugerir ou relembrar, isso seguindo as exterioridades e interioridades imagéticas de imagens que nos entornam, gostaríamos de selecionar cincoimagens nas quais se sugere a aparição de elementos recorrentes e regulares encontradosna vida e obra de Yayoi Kusama, Imagens essas que reverberam, por conseguinte, na vida e obra de Salvador Dalí.

Desse modo, diante da cronologia visual proposta a seguir alargaremos o campo do discurso da loucura no establishment das artes a partir da verificação da repetição da figura do sujeito "artista-louco" inserida nele. Para tanto, elegemos como base e unidade material significante as unidades discursivas "Kusama" e "Dalí" sob o efeito do estranhamento que se materializa tanto em nós, em forma de sentimento, como no sujeito histórico "artista-louco". Com isso promovemos o exame dessa produção histórica escavando as margens do ofício do artista-louco, bem como já o analisamos admissível a partir da perspectiva foucaultiana das práticas de si que assim o subjetiva/objetiva enquanto tal.

Principiemos na década de 1960, para tanto. Na primeira imagem, apreendemos Kusama (figura 17) fotografada trabalhando antes de receber seu diagnósticopsiquiátrico. Como sabemos, a pintora saiu do Japão em 1957 aos 28 anos de idade. Residindo em Nova York entre 1958 e 1973, após a recepção calorosa de suas pinturas da série Redes Infinitas (Infinity Nets) já a recepção de suas esculturas da série Acumulação (Accumulations) não foi similar devido ao seu "caráter psicossexual” (MORRIS, 2013. p. 82). Esta rejeição aliada às dificuldades financeiras "levou Kusama à depressão e ela procurou a ajuda da psicanálise, embora tenha afirmado posteriormente que a terapia a prejudicou em lugar de ajudar" (MORRIS, 2013, p. 82).

45 Apud MILANEZ, 2015, p. 203. BELTING, citado em Imagem, mídia e corpo. Uma nova abordagem àiconologia. 2006, s/p. 


\section{Eu, Yayoi Kusama, que pintei minha obliteração, minha obsessão e minhas fobias}

Desse período, destacam-se seus happenings e performances que "geralmente traziam conteúdos radicais de nudez sexualmente explícitos e politicamente radicais" (MORRIS, 2013, p. 82). Todavia, suas apresentações atraindo a grande cobertura da imprensa "fizeram da artista uma celebridade menor, embora contribuindo para marginalizá-la no contexto do establishment da arte, para o qual os eventos eram meras estratégias de publicidade" (MORRIS, 2013, p. 82). Estratégia ou não, no tocante à performance de usar os corpos dos modelos como suporte direto da tinta usada pelo artista, nos interessa aqui pontuar que não foi Kusama a fazê-lo primeiro.

Reservadas as devidas proporções estéticas, temáticas e políticas, verificamos a mesma empreitada registrada pelas mãos de Dalí (figura 18) em Salvador Dalí drawing on the forehead of Gala; fotografia tirada em Figueres, na Espanha, em 1970. Observemos essa recorrência técnica figurada pelo empreendimento artístico desses dois artistas:
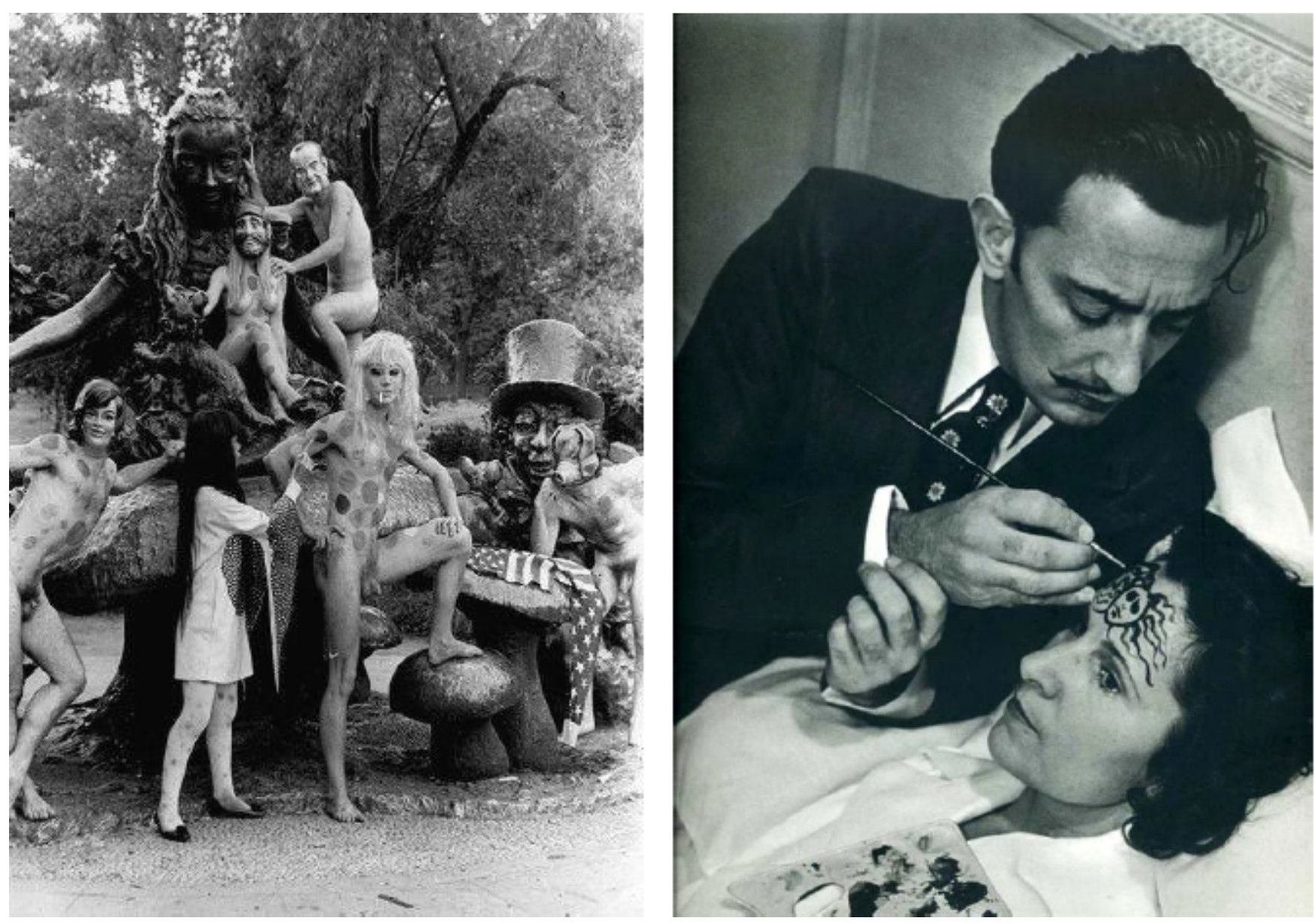

Figura 17 - Happining Explosão Atômica diante da escultura de Alice no país das maravilhas, Central Park, NY, 11 ago. 1968. Fonte: MORRIS, 2013, p. 174.

Figura 18 - Salvador Dali drawing on the forehead of Gala. Figures, Espanha, 1970. Photo (C) Fhillipe

Halsman. Fonte: Disponível em: https://br.pinterest.com/pin/94575660905913457/

Acessado 17 junho 2016. 


\section{Eu, Yayoi Kusama, que pintei minha obliteração, minha obsessão e minhas fobias}

Ainda na década de 1960, vislumbremos agora a recorrência estético-fálica posta em jogo por esse sujeito histórico "artista-louco" que delineamos. Em seu turno, visualizamos, por exemplo, a aterrorizada Kusama que produz falos por acumulação diz, em posse desse elemento (figura 19), que "a mais drástica idéia de forçar o públicoa passar... confiança é a fantasia inconsciente de castrar o público..." propondo para tanto que "nenhum de vocês [expectadores] têm pênis. Eu no papel de uma pessoa castrada, estou mostrando a vocês como vocês devem agir" ${ }^{46}$.

Como é de se esperar, Salvador Dalí também figurou/figurou-se ao lado de falos (figura 20). De interesse ao seu expediente, o qual segundo Fer, Breton diz que "a beleza [surrealista] é apenas o grau de consciência de nossas perversões" (FER, 1993, p. 203), eis que os falos daliescos se associam às "calças manchadas"; à "figura que contempla sua própria emasculação com "serenidade"” adotando assim "uma atitude degradante e repulsiva" (FER, 1993, p. 203). Dessa acumulação fálica apreendida nas esteiras dos dois artistas, relacionamos o dito objeto em mãos de seus jogadores ressoando próximas conforme se apreende abaixo:
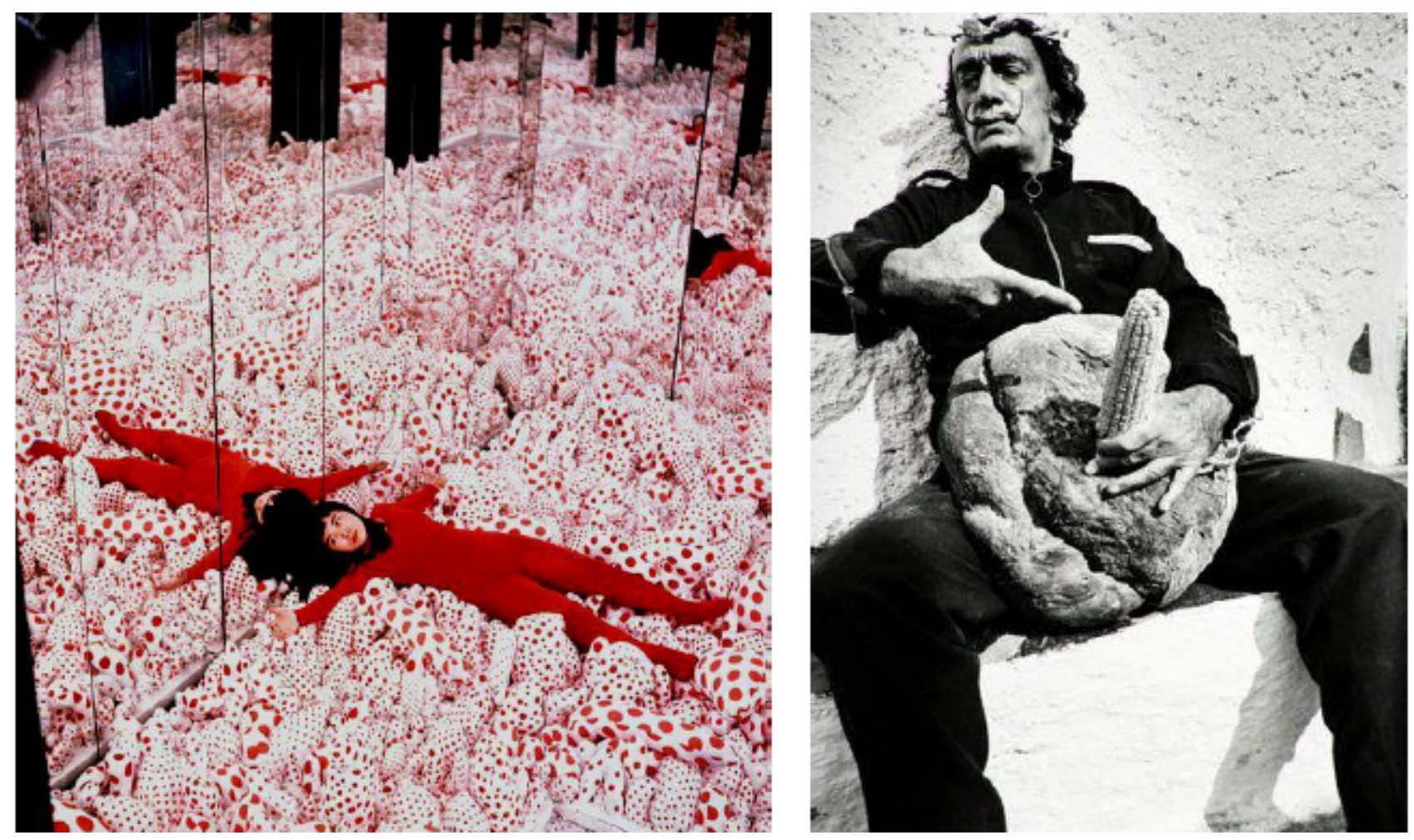

Figura 19 - Infinity Mirror Room, Phall's Field (of floor show), 1965/2013 Fonte: MORRIS, 2013, p. 127.

Figura 20 - Salvador Dalí fotografado em Paris, 1980. Photo (C) Laszlo Veres. Fonte: Disponível em: https://br.pinterest.com/pin/228276274834858378/ Acessado 18 junho 2017.

46 Declarado de Kusama em Fenichel, On Acting. In Collected Papers, p. 359-360. Apud in LARRATT-SIMITT, 2013, p. 92). 


\section{Eu, Yayoi Kusama, que pintei minha obliteração, minha obsessão e minhas fobias}

Prosseguindo com nossa cronologia visual intericonica, passemos a década de 1970. É no final desse decênio que a artista "fixou residência nas dependências abrigadas de um hospital psiquiátrico em 1977" (MORRIS, 2013, p. 56). A partir daí, reconhecida/autorizada tanto como pelos poderes-saberes do establishment como pelos poderes-saberes psiquiátricos, é que Kusama - agora "artista-louca" (figura 21) - sai todos os dias da instituição para por em dia à prática de seu ofício. Desde então, a artistasempre é registrada/ registra-se publicamente na figura objetiva/subjetivada do sujeito artista louco (usando peruca vermelha e vestes estampadas de bolinhas ou falos, trabalhando compulsivamente sobre suas pinturas), tal como outrora se expusera Dalí nas artes de seu ofício (teatralizava sua loucura cobrindo-se de tinta, excedia a expressão de seu rosto - olhos arregalados e bigodes sempre voltados para cima; figura 22):

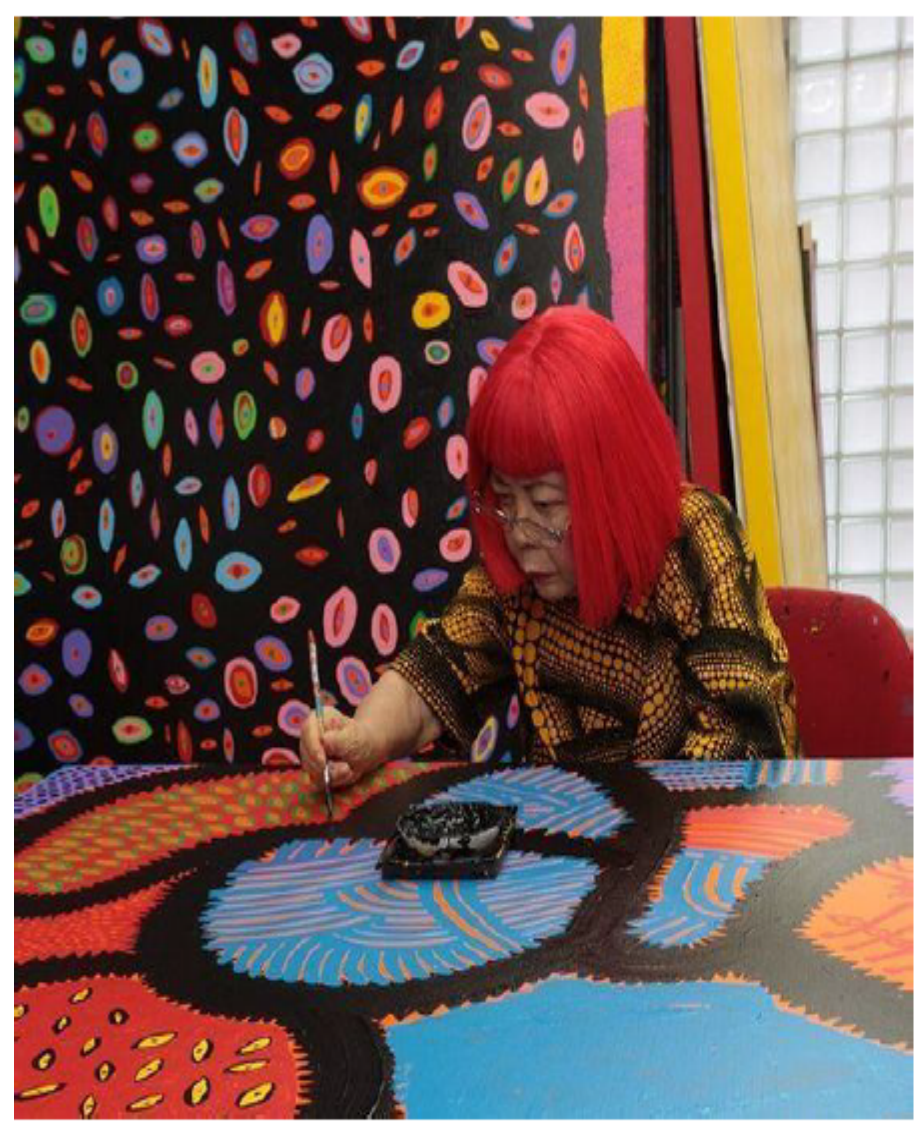

Figura 21 - Kusama objetivada/subjetivada pela loucura 2.

Fonte: Photo $\mathbb{C}$ Harry Seymur, 2015.

Fonte: Disponível em: < https://br.pinterest.com/ $\operatorname{pin} / 312296555400241439 />$

Acesso 12 junho 2017.

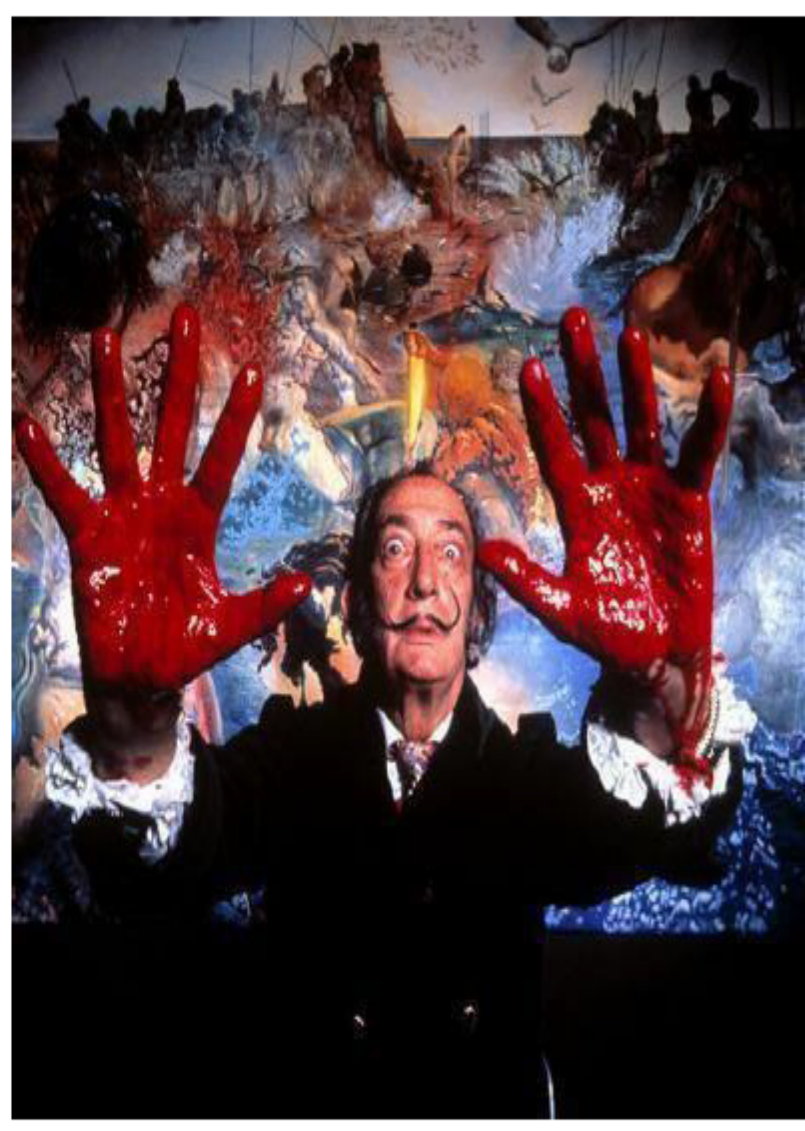

Figura 22 - Portrait of Dali, 1970. Photo (C) Phillipe Halsman, 1970.

Fonte: disponível em: https://br.pinterest. com/pin/561261172286166293/

Acessado em 18 junho 2017. 


\section{Eu, Yayoi Kusama, que pintei minha obliteração, minha obsessão e minhas fobias}

Não obstante, aproximemos ainda mais Kusama e Dalí nessa posição sujeito histórico "artista-louco" que alinhamos aqui. Tal como acenamos anteriormente sobre a parceira de Kusama com a Maison francesa Louis Vuitton, essa na ocasião do lançamento de sua grife pela coleção "Cápsulas" em 2013, em elaboração conjunta com o designer de moda Marc Jacobs (figura 23) que tomou emprestado da artista a sua estética pontilhada e fálica para os acessórios de luxo da marca, notadamente, também encontramos Salvador Dalí próximo das passarelas do universo da moda.

Acontece que Marc Jacobs também não foi o primeiro grande estilista a se interessar pelo universo da arte. Assim como já o fizera a design Elsa Schiaparelli (1890-1973), na época, o jovemYves Saint Laurrent (1936-2008, figura 24) também se aproximou do artista catalão atrás de inspiração para sua moda. Assim como Salvador Dalí, "Pablo Picasso, Henri Matisse, Van Gogh, Claude Monet, Serge Poliakoff, Tom Wesselmann e George Braque"47, foram todos nomes lançados em suas coleções.

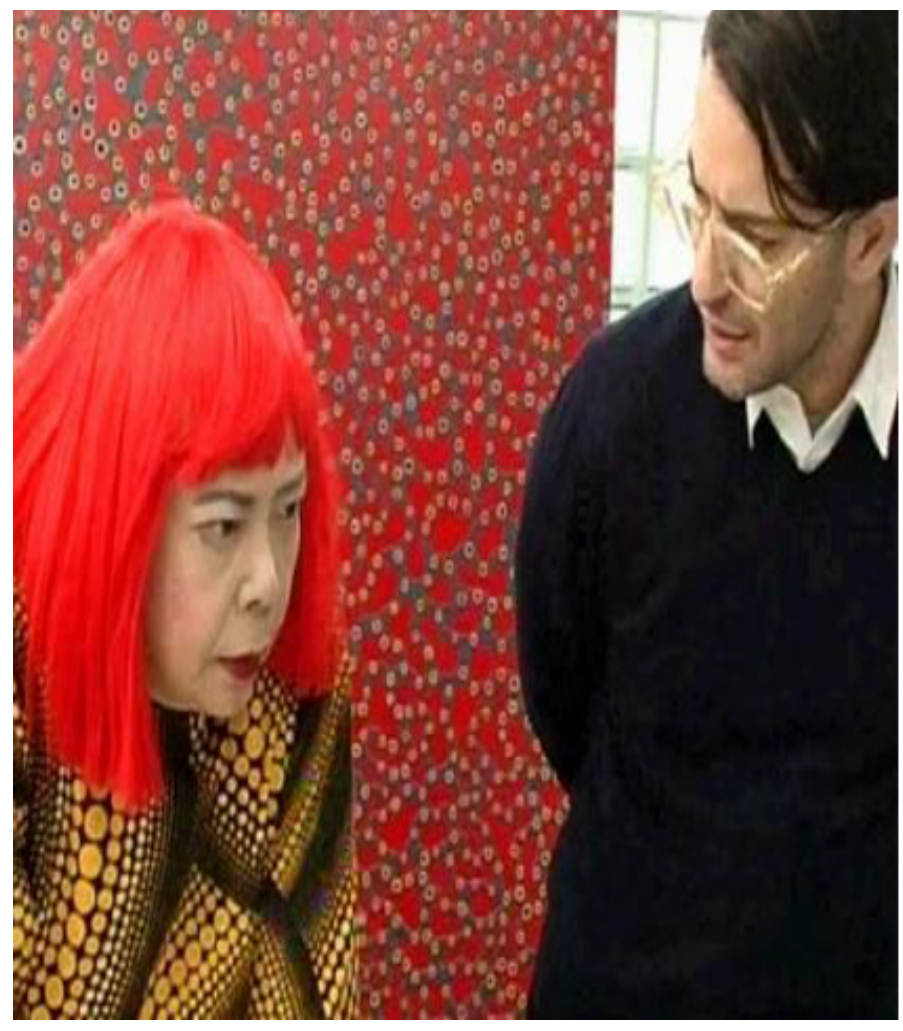

Figura 23 - Kusama e Marc Jacobs 2.

Fonte: Photo (C) Gautier Deblonde, 2012. Disponível em: < http://fadmagazine.com/2012/01/10/ marc - jacobs -recruits -yayoi-kusama -for-art-installation -collaboration/ > Acesso 12 junho 2017.

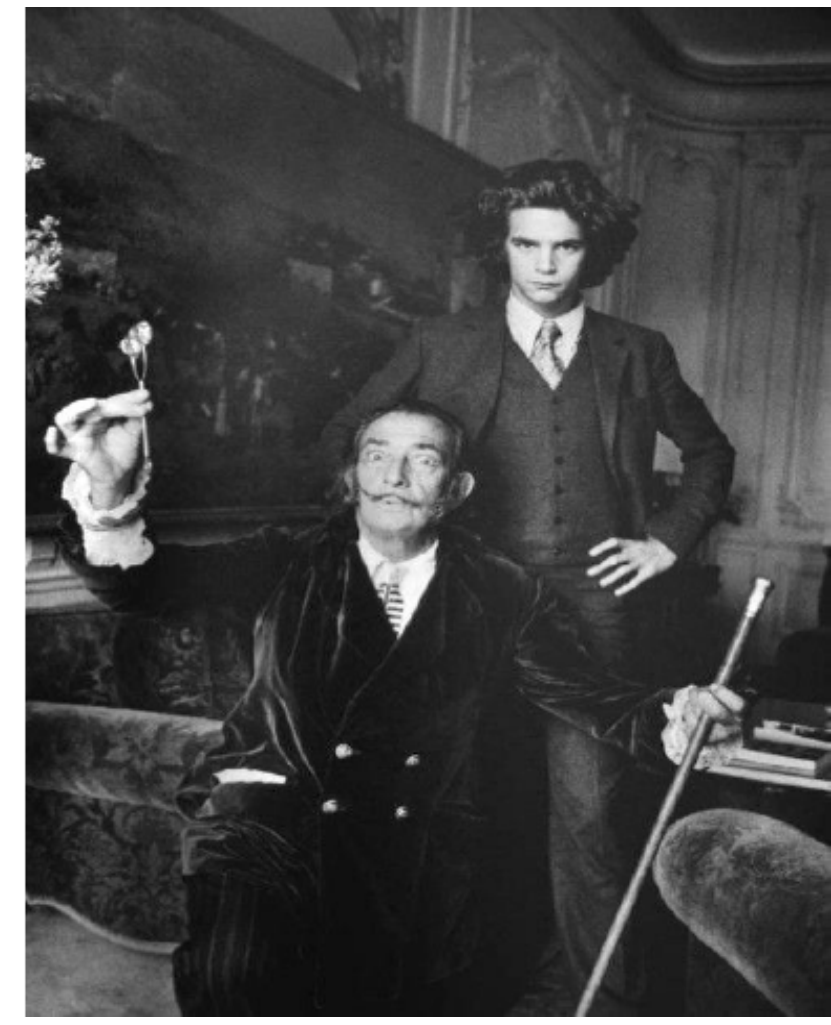

Figura 24 - Salvador Dali and Yves Saint Laurent, s/d. Photo (C) Alécio De Andrade, Fonte: disponível em: https://br.pinterest. com/pin/55147991685399 1103/ Acesso 18 junho 2017.tion/ > Acesso 12 junho 2017.

47 Disponível em: http:/gnt.globo.com/moda-e-beleza/materias/quando-a-moda-encontra-a-arte. htm Acesso 18 junho 2017. 


\section{Eu, Yayoi Kusama, que pintei minha obliteração, minha obsessão e minhas fobias}

Por derradeiro, gostaríamos de mostrar com essa cronologia visual intericonica as duas vozes que "falam" na posição-sujeito histórico "artista-louco" que escavamos. Para tanto, propomos o nivelamento de dois sujeitos que, em razão do exercício da "governamentalidade do si" associado tanto às "técnicas de si" como aos "jogos de verdade", hoje e ontem vieram devidamente a ocupar/fabricar esse lugar no establishment das artes contemporâneas. Apreende-se, portanto, de um lado a posição sujeito "artista-louco" hoje atualizada sob a máscara dessa unidade discursiva a "Sacerdotisa das Bolinhas" (figura 25), Yayoi Kusama, que exclama:

minhas performances são um tipo de filosofia simbólica com bolinhas.A bolinha tem a forma do sol, que é um símbolo da energia do mundo inteiro e de nossa vida, e também, a forma da lua, que é calma. Redonda, suave, colorida, ignara e sem sentido. As bolinhas não podem ficar sós; como a vida comunicativa das pessoas, duas, três ou mais bolinhas entram em movimento. Nosso planeta é apenas uma bolinha entre milhões de estrelas no cosmos. As bolinhas são um caminho para o infinito. Quanto obliteramos a natureza e nossos corpos com bolinhas, nos tornamos parte da unidade de nosso ambiente. Eu me torno parte do eterno e nós nos obliteramos no amor $^{48}$ (MORRIS, 2013, p. 55).

Do outro, encontramos ocupando o mesmo espaço, posição sujeito "artista-louco", um sujeito aí residindo anteriormente sob a máscara do "pintor-excêntrico" (figura 26). Esse, em setembro de 1974, na ocasião de seus 70 anos, numa mostra retrospectiva onde expunha um repertório de objetos de afeto e vitrine de suas mais célebres iconografias, numa última brincadeira surrealista disse:

$\mathrm{Eu}$, Salvador Dalí, católico apostólico romano, apolítico por excelência e espiritualmente monárquico, constato com modéstia e alegria que todos os meus impulsos criativos de juventude contemporânea convergem hoje em uma única virtude: a oposição à cultura burguesa [...] Trago à nova revolução aquilo que disponho: o meu método paranóico-crítico, singularmente consoante, me parece, à natureza felizmente irracional dos acontecimentos em curso (PUPPO, 2011, p. 36).

Encontradas as vozes que falam da posição sujeito "artista-louco" que escavamos do establishment das artes contemporânea e surrealista, visualizados os lugares e datas os quais esses corpos se inserem e apontam, tendo desse modo, portanto estabelecido os

48 Declaração de Yayoi Kusama em entrevista com Jed Jalkut, The New York Free Press \& West SideNews, Nova York, 15 de Fevereiro de 1968. 


\section{Eu, Yayoi Kusama, que pintei minha obliteração, minha obsessão e minhas fobias}

limites que fazem com que esses corpos apareçam num dado momento, num dado lugar e não em outro, pontuamos a posição sujeito "artista-louco" indicada pelo alinhamento desses dois artistas locos extraordinários, Kusama e Dalí:

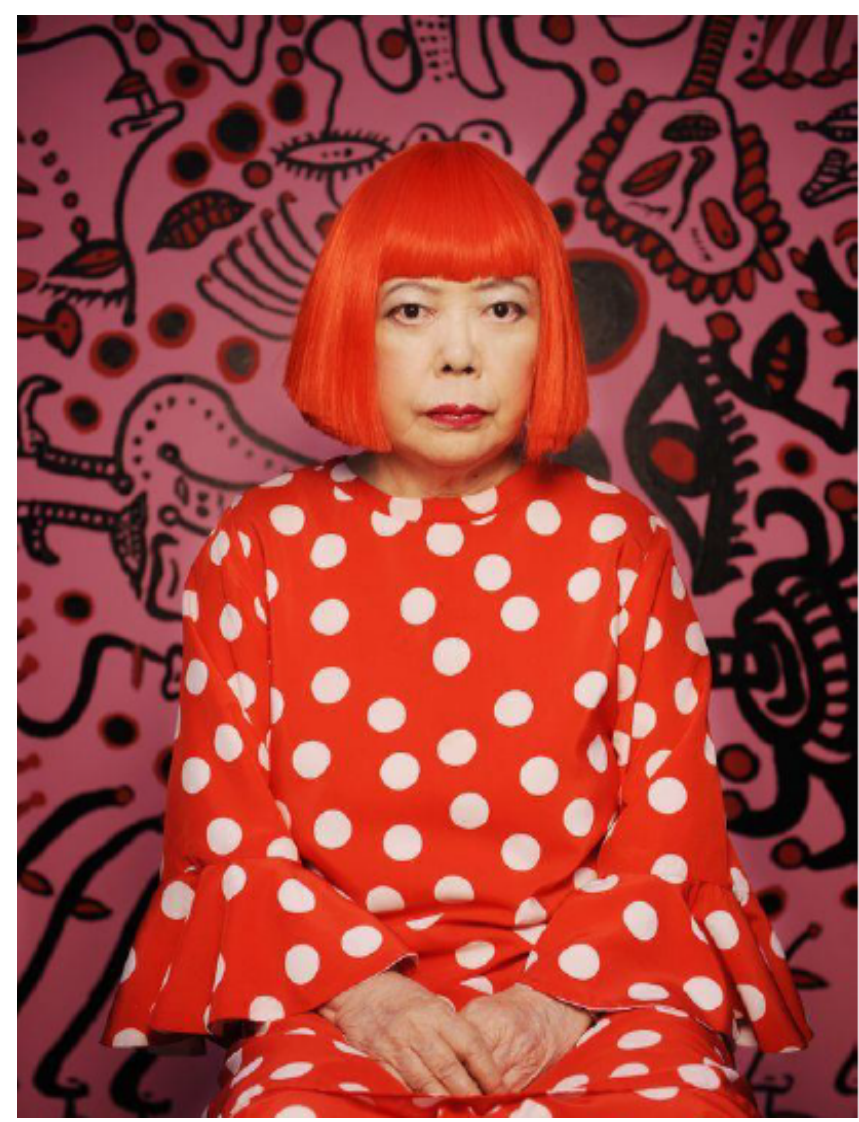

Figura 25 - Yayoi Kusama, "Suprema Sacerdotisa das Bolinhas", 2011. Fonte: Frances, 2013, p. 191

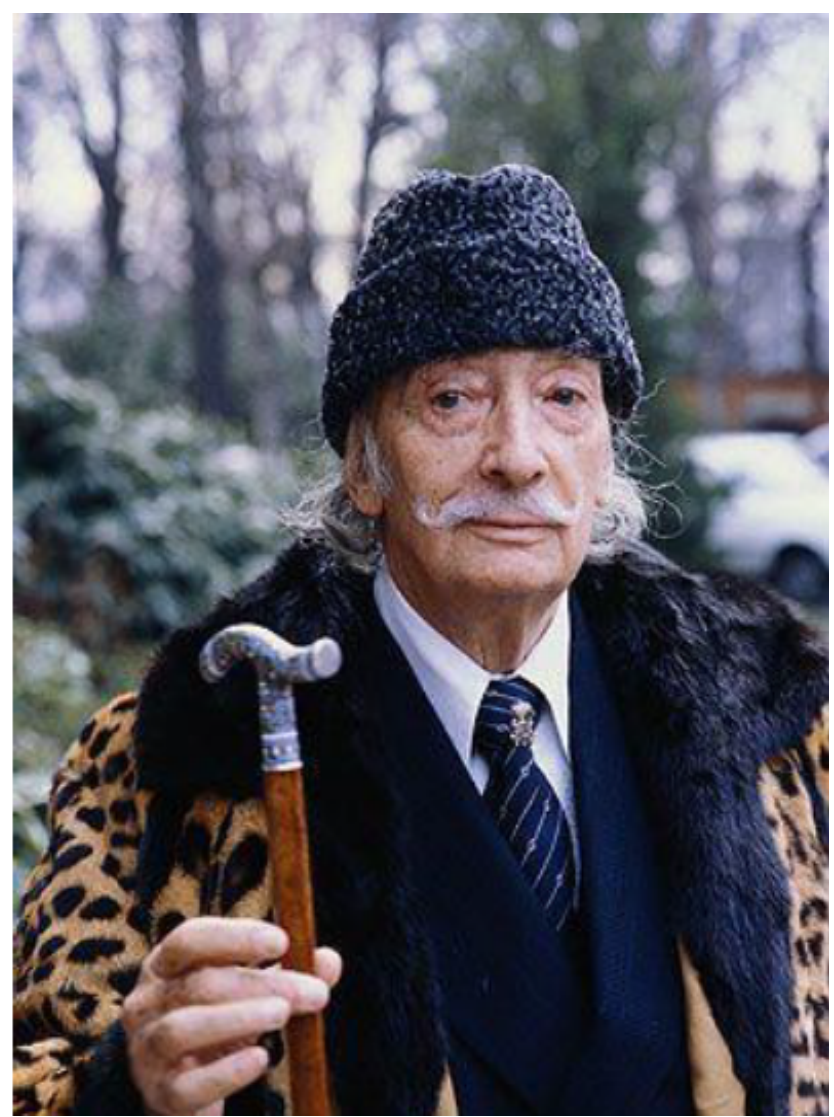

Figura 26 - Salvador Dalí fotografado em Paris, "Conde Excêntrico", 1980. Fonte: Photo (C) Laszlo Veres, 1980.

Disponível em: https://br.pinterest.com/ pin/73957618860297178/ Acesso 12 junho 2017.

Com isso, conforme nos propomos no início deste capítulo, diante da escansão das materialidades significantes detectadas nas margens dos enunciados "obras-primas" de Kusama, que por sua vez reverberam (como se pôde apreender dessa cronologia estético-imagética intericonica) nas margens dos enunciados "obras-primas" de Dalí, eisque deciframos o corpo discursivo "artista-louco". Isso tendo focalizado na vida e obra de Kusama e Dalí como existências materiais dessa posição sujeito, que aqui denominamos corpo em consonância com suas formas, seus respectivos status materiais e por meio da representação sob a qual os identificamos: a materialidade significante estético-patológica na qual se inscreve o discurso imagético da loucura. 


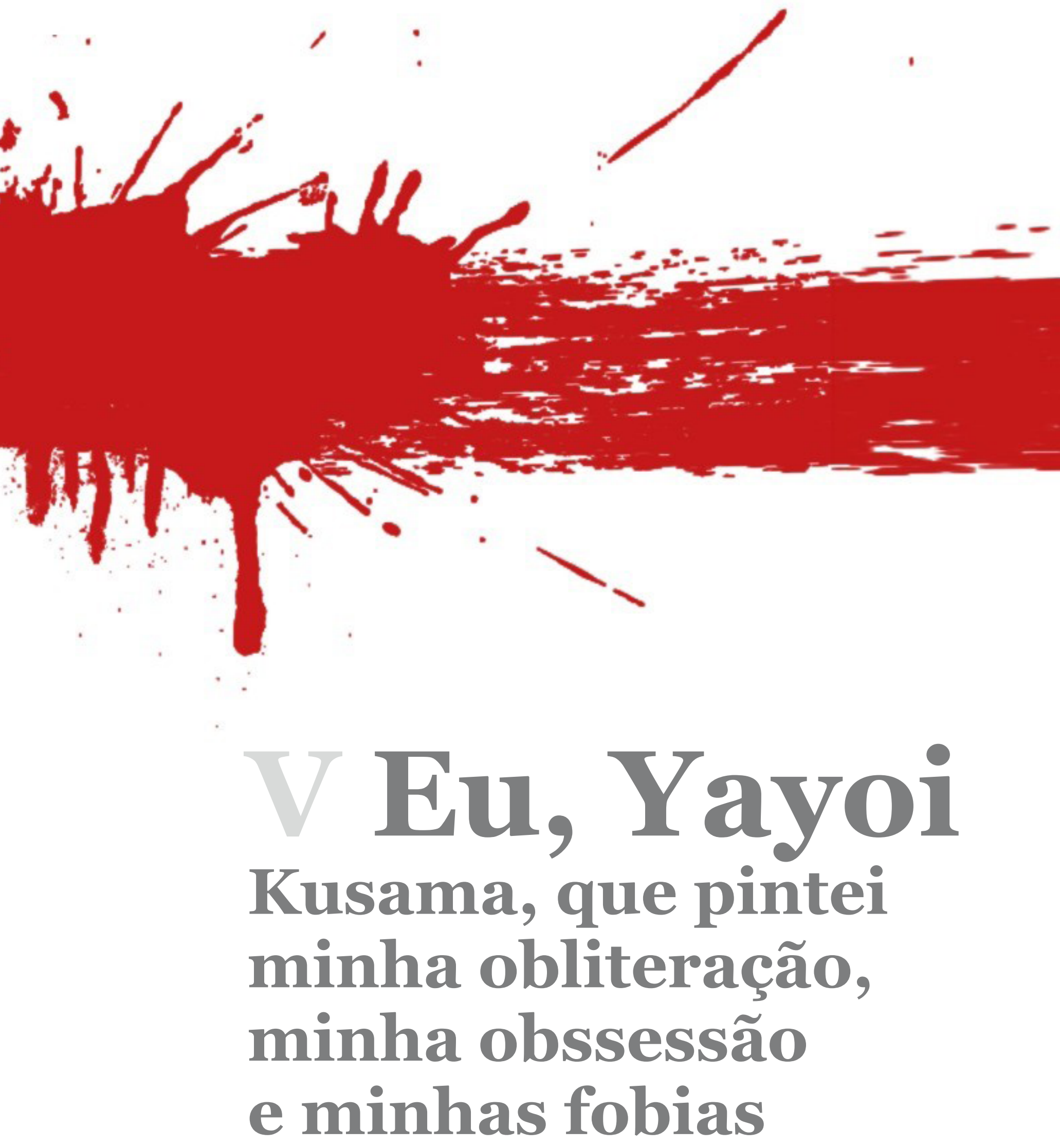


"Somos diferença, nossa razão é a diferença dos discursos, nossa história a diferença dos tempos, nosso eu a diferença das máscaras. A diferença, longe de ser origem esquecida e recoberta, é a dispersão que somos $e$ fazemos. "49

Michel Foucault

De início, foi a possibilidade de identificarmos uma materialidade significante estético-patológica nos enunciados da loucura de/sobre Yayoi Kusama que nos levou à escrita desta dissertação. Nessa busca, ao analisarmos esses enunciados verificamosuma unidade discursiva em comum: o corpo (MILANEZ, 2009), ocupando a posição sujeito-histórico "artista-louco". Assim, diante da apreensão de existências materiais dessa posição sujeito travestida de loucura(s), fomos incitados a analisar a produção discursiva em torno da persona artística/midiática Yayoi Kusama.

Como resultado, da consonância de suas formas, de seus respectivos status materiais e de suas interpretações da loucura, ou seja, de seus enunciados "obrasprimas", esses, por fim, imbricados numa relação intericônica, mostramo-los parelhos à estética patológica surrealista daliesca, notavelmente. Com isso, asseveramos haver no establishment - ordem discursiva da história da arte, não apenas em sua contemporaneidade, uma figura em resistência aos seus poderes e saberes, o "artista- louco".

Esse "artista-louco" - outrora Salvador Dalí - hoje, atualizado em/por Yayoi Kusama, ao nosso ver, tem sua substância, sua força, calcada na parrehsia. Voltemos ao termo, derradeiramente. Em consonância com tudo o que é/foi dito até o momento, Foucault, à luz grega, faz valer a noção dos sujeitos parresiastas. Ainda sobre sua abordagem do cuidado de si, Foucault problematiza que o trabalho de formalização tem como resultado apresentar a constituição de si como sujeito ético. Esse trabalho de formalização

é o processo propriamente ético que Foucault chama de“subjetivação". O uso dos prazeres o define como um trabalho de si sobre o si que Focault também chama de "etopoiética". Uma poiética, pois se trata exatamente de se produzir como sujeito ético vivendo segundo tal regime culinário ou sexual, praticando essa ou aquela espécie de sexualidade ou de economia doméstica, mas também na medida em que se trata de imprimir à "subs-

49 FOUCAULT, Michel. A Arqueologia do saber, 2010, p. 149. 


\section{Eu, Yayoi Kusama, que pintei minha obliteração, minha obsessão e minhas fobias}

tância ética" que alguém propriamente é uma certa forma, um certo estilo. O sujeito é uma obra" (GROS, 2004, p. 133).

Dito isso, durante todo o trajeto analítico desta dissertação, pareceu-nos estar manuseando, entre enunciados e discursivisações, a medida dessa substância ética de que Focault fala. Se escandimos certa forma e estilo pessoais, abordamos, portanto, um corajoso sujeito parresiasta que prossegue com sua fabricação das dizibilidades e visualidades da estética da existência da loucura enquanto exímio ofício no domínio das artes. Isso, tendo-se em vista que, ao "dizer o verdadeiro" - que, nesse caso, chamamos de "verdade-arte", a parresiasta Kusama proclama-se artista por falar

em seu próprio nome [através de seus enunciados obras-primas] e seu discurso [materializado conforme rege a estética-patológica surrealista] refere-se a uma situação atual, singular [para os saberes/poderes do establishment artístico]. Seu lugar natural é a praçapública [não apenas o establishment, mas também o Kusama World] e ele, por fim, leva a relação com o outro [o curador de arte, o público expectador de sua mídia] à extrema tensão da ruptura possível [deuma ordem do discurso, de uma ordem do olhar] (GROS, 2004, p. 157-158).

Não obstante, foi a irrupção inesperada da parresista Kusama que nos levou a buscar a teoria e a metodologia da arquegenealogia formulada por Michel Foucault. Consideramos, dessa maneira, o que se diz e se mostra sobre Yayoi Kusama: artista interditada do cenário das artes cuja sanidade foi confiscada pelo dispositivo médico, mas que, por conta própria - forma de resistência - se internou num hospício e, somente após tal gesto, veio a ser resgatada pelo establishment. Ou seja, ao ponderamos essas discursividades e enunciados produzidos acerca desse sujeito "artista-louco" (e não outro) imerso numa rede de embate entre poderes e saberes é que constatamos possível aproximar a figura de Kusama à figura de outro parresista, Pierre Rivière.

Para esse fim, portanto, olhamos para as não evidências da vida e obra de Kusama, para os enunciados produzidos por/sobre ela os quais apontavam para a constituição/fabricação/interpretação de sua loucura. O fizemos, tal como Foucault mostrou no dossiê Rivière. Logo, desautomotizamos os discursos psiquiátricos e do establishment; seus saberes estéticos (MORRIS; LARRAT-SMITH, 2013) freudianos- surrealistas (FER, 1993; PUPPO, 2011) entrecruzados. 


\section{Eu, Yayoi Kusama, que pintei minha obliteração, minha obsessão e minhas fobias}

Isto é, cerceamos os sentidos produzidos em ressonância com a autonomia da artista nipônica, essa atrelada às vontades de verdade, à governamentalidade, às técnicas/ ao cuidado de si, e, finalmente, à parrheseria (FOUCAULT, 1994, 2006a, 2017; GROS, 2004). Nesse sentido é que evidenciamos, assim como no caso de Pierre Rivière, um "acontecimento exemplar" no acontecimento de Kusama: em seu turno,uma vez compreendida uma parresiasta, como tal ela visa projetar-se de um mundo estático para a resistência face à opressão e à ordem do poder (FOUCAULT, 2003).

A exemplo da subjetivação/obejetivação mostrada por Foucault no caso do parricida de Caen, foi possível analisarmos o corpo "artista-louco" Kusama imerso na história da arte. Nessa esteira, apreendemos um corpo notadamente irrigado pelo campo da memória sobre quem é e quem pode ser um artista ao identificarmos os lugares e dizeres (e não ditos) onde essa história e discursividades arroladas dão cor, forma e visualidade estética ao corpo de Kusama - enunciado de sua "verdade-arte", sua própria“obra-prima". Nas condições sócio-históricas em que tudo apontava para a submissãode uma mulher estrangeira, de uma artista segregada do cenário internacional das artes, porém, refutando a docilidade, Kusama abraçou a loucura e, conforme prometera, criou um trabalho revolucionário, por fim, assombrando o mundo artístico internacional.

Num segundo momento analítico, salientamos os aspectos teóricos metodológicos da Semiologia Histórica (GINZNURG, 2014), a fim de que pudéssemos agregar ao escopo teórico da Análise do Discurso, aqui amparada pelo postulado arqueológico de Foucault, os enunciados trabalhados (as materialidades imagéticas analisadas) para além da ordem do linguístico, o que viabilizou abordá-los em sua natureza semiológica. Empregando o paradigma indiciário, por conseguinte, desse modoescandimos o enunciado Obsessão por sexo e comida (1966) decifrando suacomposição à luz da estética surrealista, mais precisamente, a daliesca. Fato que, juntamente aos indícios do corpo feminino nu (principal unidade discursiva da obra) e a aglomeração fálica, nos levou, sincreticamente, às margens de outro enunciado: Virgem Auto-Sodomizada pela sua Própria Castidade (1954).

Nesse passo, observando a circulação desses enunciados verbais e não verbais, e, também, pensando sobre sua força enquanto operadores da memória social, no que diz respeito à iconografia fundadora da cultura ocidental, é que trouxemos à esteira desta 


\section{Eu, Yayoi Kusama, que pintei minha obliteração, minha obsessão e minhas fobias}

pesquisa os conceitos de "memória discursiva" e "intericonicidade" (COURTINE, 2013). Dessa maneira, abriu-se o olhar para um quebra-cabeça visual (não completo) do sujeito, posição histórica, "artista-louco".

Finalmente, fechamos os exercícios analíticos mostrando as contínuas (re)atualizações do campo de memória sobre os artistas loucos. Com isso, chegamos a uma ordem discursiva do establishment materializada pelos enunciados surrealistas de Salvador Dalí. Assim, demos visibilidade, por meio de nossa cronologia visual intericônica, à fabricação da posição histórica do "artista-louco" Kusama e Dalí por meio da repetição; um eco imagético ressoado nas práticas discursivas desses dois artistas em suas militâncias, excentricidades, parcerias artísticas e mesmo numa auto gestão empreendedora. De resto, apoiamo-nos nos espaços interdiscursivos dos happinings e do savoir-faire fabricados por Kusama, apreendemos, sobremodo, a transição do corpo Kusama antes de seu confisco pelo dispositivo médico e seu corpo após sua subjetivação/objetivação da persona "artista-louco”. Posição que mantém seu rastro histórico, hoje, atualizada pela máscara rubra, fálica e pontilhada da "Suprema Sacerdotisa das Bolinhas".

Esta obra, obviamente, não pretende uma completude. Comodemonstramos, Yayoi Kusama confecciona a si mesma numa rede, ora subjetivando-se, ora objetivando-se, associada a vários outros sujeitos artistas cujas existências se deram - interdiscursivamente - porque não eram artistas, ou porque eram "artistas-loucos", eram, antes, simultaneamente, ambos. Ao concluirmos nossos apontamentos, diante do espetáculo das núpcias da loucura com as artes que aqui abraçamos, gostaríamos de reafirmar a posição de sujeitos como Bosch, Arcimboldo, Blake, Ensor, de Chiriro, Van Gogh, Duchamp, Dalí e Kusama. Sujeitos que abordamos via Análise do Discurso e quesutilmente escavamos neste estudo para procurar aliar um sujeito do presente - autônomo em suas transformações - aos sujeitos visíveis e dizíveis pelos contornos de um corpo que vão fabricando, não para a história evidente aos olhos do corpo quetemos, mas do corpo de um novo sujeito por vir.

Que enunciados esses sujeitos nos revelariam, a que destino historicamenteconstruído estaríamos fadados? Qual seria o papel da imagem, da estética plástica no estabelecimento da memória coletiva em tempos que a visualidade tem proeminência cada vez maior nas sociedades contemporâneas? Enigmas apenas? Não. Acreditamos que é pelo 


\section{Eu, Yayoi Kusama, que pintei minha obliteração, minha obsessão e minhas fobias}

exame do olhar que decifraremos os corpos traçados, esboçados, retratados tão exclusivamente pelas nossas vontades de criar verdades para novos sujeitos; novas vidas. Como aquela que Yayoi Kusama esboçou para si: não se limitou às fronteiras espacial-geográficas de seu nascimento em Matsumoto, província de Nagano; pacata estância hidromineral dominada por um castelo do século XVI, nos Alpes Japoneses. Projetou-se sobre o mundo, dançou bem na era dos espetáculos.

Tão pouco ela se limitou às fronteiras espaciais discursivas; abriu o seu caminho suplantando o estilo tradicional de pintura oriental em nanquim sobre papel e seda: preferiu falos e bolinhas. Isolada, cultivou nítida influência do surrealismo. Rejeitada, de um hospício tornou sua arte numa metamorfose pop iconográfica. Perturbadora e/ou acolhedora, obsessiva e/ou suicida, despida e/ou paramentada, autodestruindo-se e/ou refazendo-se, ao exemplo de sua prática, sua parrhesia, vislumbramos um solo arqueológico desenhado por nós mesmos, no qual, auto-retratos como os de Kusama, oude Pierre Rivière, estão expostos face à composição histórica que nos precedeu lembrando-nos, por fim (isso, se corajosos com a verdade e seus riscos), de nossa capacidade para criarmos percursos outros, múltiplos, mesmo, porque não, a estrada da imortalidade nas artes. Tal como Kusama perpetrou-se ao fazer de si sua própria obra-prima. 


\section{REFERÊNCIAS BIBLIOGRÁFICAS}

ARAÚJO, Inês Lacerda. Do signo ao discurso: introdução à filosofia da linguagem. In: Avaliando as consequências da análise foucaultiana do discurso. São Paulo: Parábola, 2004.

. Foucault e a crítica do sujeito. 2 ed. Curitiba: Ed. da UFPR, 2008.

ARTIÈRES, Phlippe; GROS, Frédéric. Foucault: a coragem da verdade. Tradução de Marcos Marcionilo. São Paulo: Parábola editorial, 2004.

AUTHIER-REVUZ, Jacqueline. Heterogeneité montrée et heterogeneité constitutive: elements pour une approche de l'autre dans le discours. In: $D R L A V$-Revuede Linguistique, 26, 1982, p. 91-151.

- Heterogeneidade(s) enunciativa(s). Cadernos de Estudos Lingüísticos. Campinas, n.19, p.25-42, jul/dez 1990.

BARTHES, Roland. A câmara clara: notas sobre fotografia. Tradução de Júlio Castañon Guimarães. ed. especial. Rio de Janeiro: Nova Fronteira, 2015.

. Mitologias. $4^{\mathrm{a}}$ ed. Rio de Janeiro: DIFEL, 1957.

Mythologies. Édition Illustrée établie par Jacqueline Guittard. Éditions de Seuil, 2010.

. O óbvio e o Obtuso. Tradução de Isabel Pascoal. $1^{\text {a }}$ ed. Lisboa, EDIÇÕES 70, LDA, 2009.

BECKETT, Wendy. História da Pintura. Tradução de Mário Vilela. $1^{\mathrm{a}}$ ed. São Paulo: Editora Ática, 1997.

FER, Briony; WOOD, Paul. Surrealismo, Mito e Psicanálise. In: Realismo, Racionalismo, Surrealismo: a arte no entre-guerras. Tradução de Cristina Fino. $1^{\mathrm{a}}$ ed. São Paulo: Cosac \& Naify, 1993.

CASTRO, Márcio Sampaio de. Introdução aos estudos linguísticos e semióticos: o texto nas produções escritas, visuais e áudio visuais. Rio De Janeiro: LTC, 2011. 
COURTINE, Jean-Jacques. Decifrar o corpo: pensar com Foucault. Tradução de Francisco Morás. Petrópolis, RJ: Vozes, 2013.

DEBORD, Guy. A sociedade do espetáculo. Rio de Janeiro: Contraponto, 1997.

FOUCAULT, Michel. As Técnicas de si. (Technologies of the Self. Université du Vermont, outubro, 1982. Tradução de F. Durant-Bogaert). In: Dits et écrits: A Seminarwith Michel Foucault. Vol. IV. Org(s). Hutton (P.H.), Gutman (H.) e Martin (L.H.). Tradução de Karla Neves e wanderson flor do nascimento. The University of Massachusetts Press, p. 783813, 1988. Paris: Gallimard, Vol. IV, p. 16-49, 1994.

. Dits et écrit II. Paris, Gallimard, 1736 p. 1994(a).

O sujeito e o poder. In: RABINOW, P.; DREYFUSS, H. Michel Foucault: uma trajetória filosófica. Rio de Janeiro: Forense Universitária, 1995.

As palavras e as coisas: uma arqueologia das ciências humanas. Tradução de Salma Tannus Muchail. São Paulo: Martins Fontes, 2000.

. Eu, Pierre Rivière, que degolei minha mãe, minha irmã e meu irmão. Tradução de Denise Lezan de Almeida. 7 ed. Rio de Janeiro: Edições Graal, 2003.

Retornar à História. In: Arqueologia das Ciências e História dos Sistemas de Pensamento. Organização e seleção dos textos: Manoel Barros da Motta: tradução: Elisa Monteiro - 2. ed. - Rio de Janeiro: Forense Universitária, 2005.

. Estratégia, poder-saber. Org. Manoel Barros da Motta. Tradução de Vera Lúcia Avellar Ribeiro. 2 ed. Rio de Janeiro: Forense Universitária, 2006.

O poder psiquiátrico: curso dado no Collège de France (1973-1974). Org(s). LAGRANGE, Jacques; EWALD, François; ALESSANDRO, Fontana. Tradução de Eduardo Brandão. $1^{\mathrm{a}}$ ed. São Paulo: Martins Fontes, 2006(a).

Microfísica do poder. Rio de Janeiro: Graal, 2007.

. A ordem do discurso. 18 ed. São Paulo: Edições Loyola, 2009.

A arqueologia do Saber. Tradução de Luiz Felipe Baeta Neves. 7 ed. Rio de Janeiro: Forense Universitária, 2010. 
História da Sexualidade 1: vontade de saber. Tradução de Maria Thereza da Costa Albuquerque e J. A. Guilhon Albuquerque. 4 ed. Rio de Janeiro/São Paulo: Paz e Terra, 2017.

GINZBURG, Carlo. Mitos, emblemas, sinais: Morfologia e história. Tradução de Federico Carotti. São Paulo: Companhia das Letras, 2014.

GREGOLIN, M. R. Análise do discurso e semiologia: enfrentando discursividades contemporâneas. In: Discurso, semiologia e história. CURCINO, Luzmara; PIOVEZANI, Carlos; SARGENTINI, Vanice. (orgs.). São Paulo: Claraluz, 2011.

Identidade: objeto ainda não identificado? Estudos da Linguagem. Vitória da Conquista: UESB, 2007.

KUSAMA, Yayoi. Infinity Net: The Auto biography of Yayoi Kusama. Tradução (inglês) Ralph McCarthy. Chicago: The Universityof Chicago Press, 2011.

KUSAMA, Yayoi. Waga Tamashi no HenrekitoTatakai (Odisseia de Minha Alma em Conflito), in: Geijutsu Seikatsu, vol. 28, n 11.Tradução: Izumi Nakajima. In: "Yayoi Kusama between Abstraction and Pathology". In: Pollock, Griselda (ed.), Psycho analysis and the Image, 2006.

MILANEZ, Nilton. Prólogo de uma história para a vida: modelando as memórias do corpo e das identidades. Rev. Memória Conquistense. v 8, n 9, p. 17-26, 2005.

. Corpo Cheiroso, corpo Gostoso: unidades corporais do sujeito no discurso. Rev. Acta Scientiarum. Language and Culture. v 31, n 2, p. 215-222, abril-junho, 2009.

Intericonicidade: da repetição de imagens à repetição dos discursos de imagens. Rev. Acta Scientiarum. Language and Culture. v 37, n 2, p. 197-206, abril- junho, 2015.

MORRIS, Frances. Yayoi Kusama. Obsessão infinita. $1^{\text {a }}$ ed. Rio de Janeiro: Centro cultural Banco do Brasil, 2013.

ORLANDI, E.P. Análise de Discurso: princípios e procedimentos. Campinas: Pontes, 2000. 
PÊCHEUX, M. O papel da memória. In: ACHARD, P. et al. O papel da memória. Tradução de José Horta Nunes. 3. ed. Campinas: Pontes, 2010.

PÊCHEUX, M. Semântica e discurso: uma crítica à afirmação do óbvio. Campinas: Editora da UNICAMP, 1995.

Análise automática do discurso (ADD-69). In: GADET, F.; HAK, T. (Org.). Por uma análise automática do discurso. Uma introdução à Obra de Michel Pêcheux. Campinas: Unicamp, 1997. p.61-161.

.O Papel da Memória. In: ACHARD, P.et al. Papel da memória. Campinas, SP: Pontes, 1999.

PUPPO, Alessandro del. Dalí. Grandes Mestres. Tradução de Mônica Esmanhotto e Simone Esmanhotto. $1^{\text {a }}$ ed. São Paulo: Abril Coleções, 2011.

PEIRCE, Charles Sanders. Semiótica. Tradução de José Teixeira Coelho Neto. 4 ed. São Paulo: Perspectiva, 2008.

PHILIP, Larratt-Smith. Canção de uma eternal suicída. In: Yayoi Kusama. Obsessão infinita. $1^{\text {a }}$ ed. Rio de Janeiro: Centro cultural Banco do Brasil, 2013.

SAUSSURE, Ferdinand de. Curso de Linguística Geral. Org. Charles Bally; Albert Sechehaye; Albert Reidlinger. 25 ed. São Paulo: Editora Cultrix, 2006.

THIOLlENT, Michel. Maio de 1968 em Paris. Testemunho de um estudante. In: Tempo Social; Rev. Sociol. USPs S. Paulo, 10 (2). p. 63-100, outubro 1998.

\section{FILMOGRAFIA:}

FRANÇOIS, Caillat. Foucault contre lui-même. Documentário. Direção de François Caillat. The factory, Art France. 54 min. França, 2014.

\section{MUSICOGRAFIA:}

BAYNTON-POWER, David (bateria); BOOTH, Tim (vocalista); DAVES, Saul (guitarrista); DIAGRAM, Andy (trompete); GLENNIE, Jim (baixista); GOTT, Larry (guitarrista solo); HUNTER, Mark (instrument de teclas). Sit Down. Banda James. In.: álbum Getting Away With it: Live. Rough Trade Records: UMG and Sony Music Entertainment: c1989. 1 CD. Faixa 1 (4:03 min). 


\section{ANEXOS:}

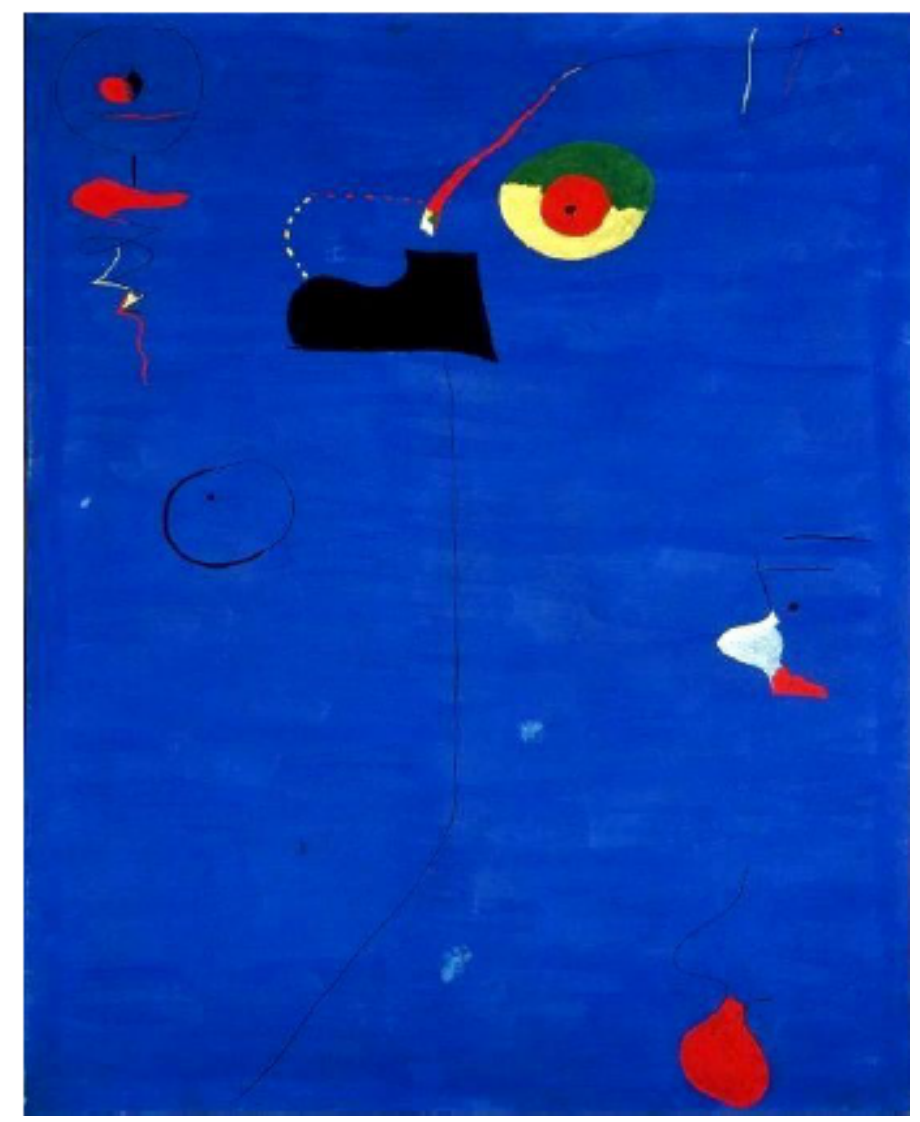

Figura 28 - Pintura, Juan Miró, 1927.

Fonte: Disponível em: https://br.pinterest.com/pin/766878642768412344/ Acessado em 2o julho 2017.

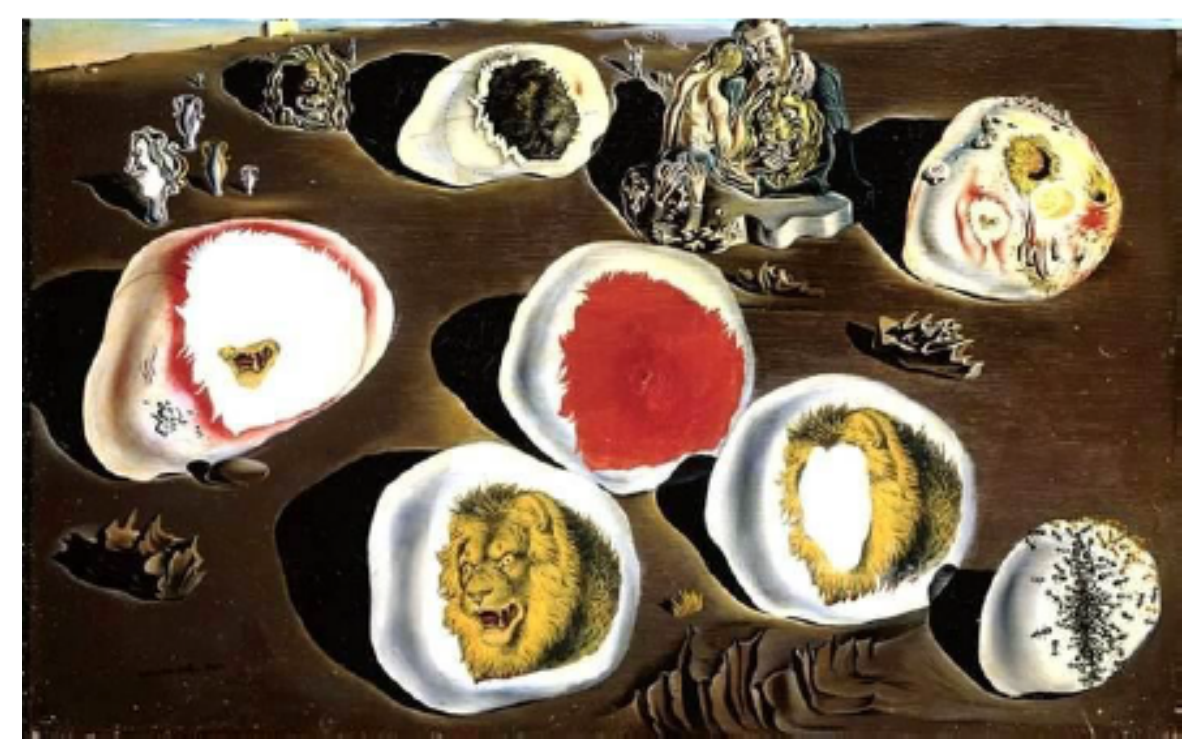

Figura 29 - As acomodações dos desejos, Salvador Dalí, 1929. Fonte: Disponível em: http://arteuniversalprezoto.blogspot.com.br/2016_05_30_archive.html Acesso 20 junho 2017. 


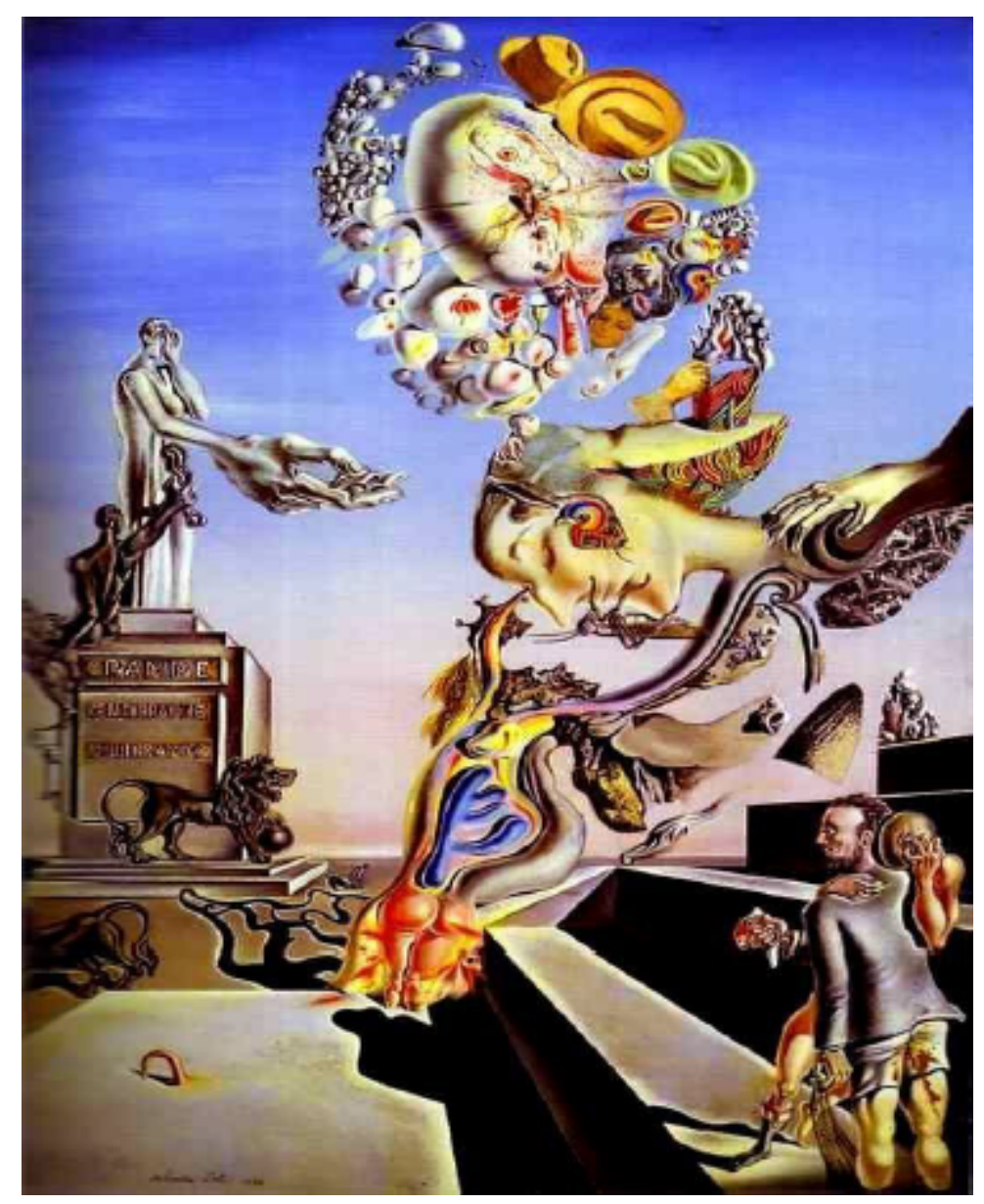

Figura 30 - O jogo lúgubre, Salvador Dalí, 1929.

Fonte: Disponível em: https://br.pinterest.com/pin/438678819936869316/ Acesso 20 junho 2017. 
www.arcoeditores.com

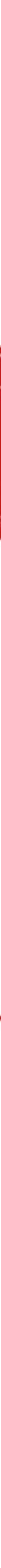

